$\overbrace{1}^{\infty}$

II)ERII MASIER

NMEI 53

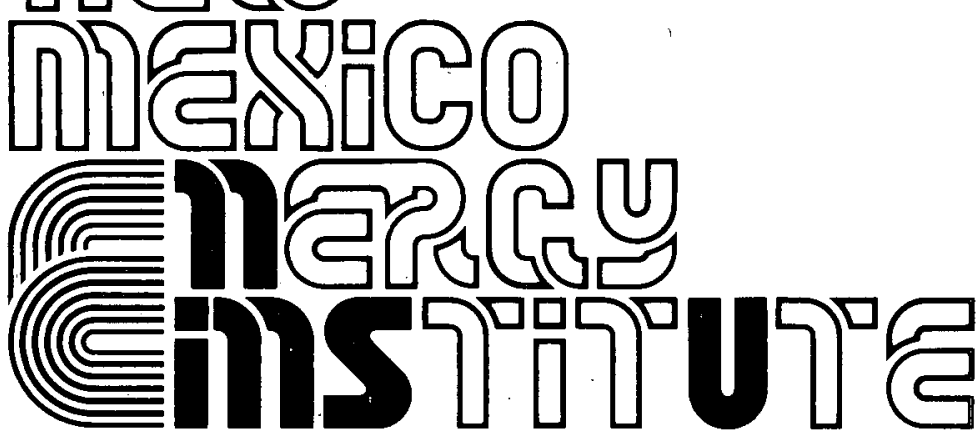

at New Mexico State University

\title{
ENVIRONMENTAL OVERVIEW
}

FOR THE DEVELOPMENT OF GEOTHERMAL RESOURCES

IN THE STATE OF NEW MEXICO

\section{FINAL REPORT \\ JUNE, 1980}

W

Martha Bryant

Arlene H. Starkey

New Mexico Energy Institute

at New Mexico State University

$$
\text { and }
$$

Dr. William A. Dick-Peddie

New Mexico Environmental Institute

New Mexico State University

$\rightarrow$ Läs Cruces, New Mexico

Prepared for the

Department of Energy

Assistant Secretary for the Environment

Inder Lawrence Livermore Laboratory

Subcontract No. 4090109 


\section{NOTICE}

Work performed under the auspices of the U.S. Department of Energy by the Lawrence Livermore Laboratory under contract number W-7405-ENG-48.

This document was prepared as an account of work sponsored by an agency of the United States Government. Neither the United States Government nor any agency thereof, nor any of their employees, makes any warranty, expressed or implied, or assumes any legal liability or responsibility for the accuracy, completeness, or usefulness of any information, apparatus, product, or process disclosed, or represents that its use would not infringe privately owned rights. Reference herein to any specific commercial product, process, or service by trade name, trademark, manufacturer, or otherwise, does not necessarily constitute or imply its endorsement, recommendation, or favoring by the United States Government or any agency thereof. The views and opinions of authors expressed herein do not necessarily state or reflect those of the United States Government or any agency thereof. 


\section{DISCLAIMER}

This report was prepared as an account of work sponsored by an agency of the United States Government. Neither the United States Government nor any agency Thereof, nor any of their employees, makes any warranty, express or implied, or assumes any legal liability or responsibility for the accuracy, completeness, or usefulness of any information, apparatus, product, or process disclosed, or represents that its use would not infringe privately owned rights. Reference herein to any specific commercial product, process, or service by trade name, trademark, manufacturer, or otherwise does not necessarily constitute or imply its endorsement, recommendation, or favoring by the United States Government or any agency thereof. The views and opinions of authors expressed herein do not necessarily state or reflect those of the United States Government or any agency thereof. 


\section{DISCLAIMER}

Portions of this document may be illegible in electronic image products. Images are produced from the best available original document. 
ENVIRONMENTAL OVERVIEW

FOR THE DEVELOPMENT OF GEOTHERMAL RESOURCES

IN THE STATE OF NEW MEXICO

\author{
by \\ Martha Bryant \\ Arlene H. Starkey \\ New Mexico Energy Institute \\ at New Mexico State University \\ and
}

Dr. William A. Dick-Peddie

New Mexico Environmental Institute

New Mexico State University

Las Cruces, New Mexico

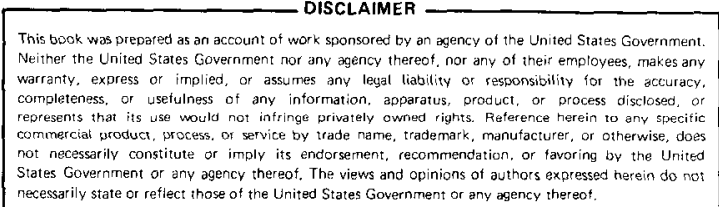

necessarily state or refiecr those of the United States Government or any agency thereof.

\author{
Prepared for the \\ Department of Energy \\ Assistant Secretary for the Environment \\ Under Lawrence Livermore Laboratory \\ Subcontract No. 4090109
}

FINAL REPORT

June, 1980

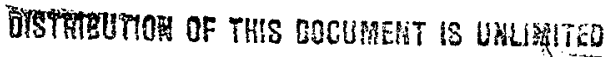


The information presented in this document has been provided by the New Mexico Energy and Minerals Department (EMD), the Environmental Improvement Division (EID) of the New Mexico Health and Environment Department, the Environmental Protection Agency (EPA), the New Mexico Energy Institute at New Mexico State University (NMEI), the Agricultural Experiment Station (AES), the Soil Conservation Service (SCS), the United States Geologic Survey (USGS), Union Geotherma1 of New Mexico, the Public Service Company of New Mexico (PNM), Los Alamos Scientific Laboratories (LASL), and Lawrence Livermore Laboratory (LLL) and by the New Mexico participants in the Low Temperature Resource. Assessment Program and the Regional Operations Research Program in the Rocky Mountain Basin and Range Region, Department of Energy (DOE/DGE) funded programs.

We wish to acknowledge the individual contributions of the following (in alphabetical order): Nancy A1varado, Lynn Anspaugh, John Bartlit, Dan Beach, Patrick Beckett, Lyle Berger, Douglas Brookins, Jonathan Callender, Gary Carlson, Charles Chapin, Lokesh Chaturvedi, Richard Christ, Cubia Clayton, Paul Cox, Neil Crow, Roy Cunniff, James Edwards, Pauline Eisenstadt, Wolfgang Elson, Lynn Gelhar, Fred Gross, Jr., Edward Groth, Dennis Grover, Keith Guard, Narendra Gunaji, Yasha Gupta, Arthur Houghton, Y. C. Hsu, Peter Huyakorn, William Isaacs, Calvin Jackson, George Jiracek, F. D. Ju, Satish Kamat, David Kauffman, William Kersting, Conrad Keyes, Jr., Albert Kudo, Vernon LeFebre, Leo LaFrance, Gary Landis, Robert Lansford, Phil Leitner, James Libberton, Y. M. Lu, John Ludwig, Arthur Mansure, Joe Marlin, William McCoo1, Paul McDevitt, Alan Miller, Nancy Mizel, Charles Mohlenkamp, Robert Moon, Paul Morgan, David Mott, Robert Munson, Kenneth Nowotny, Glenn Palmore, Patrick 0'Dea, Paul Phelps, Pauline Pino, Robert Quade, James Querry, Ken Rea, Marshall Reiter, Martin Rinaldi, Chennupati Raghavenora, David Sabo, Harold Sando, Alan Sanford, Curtis Schaafsma, John Schlue, George Scudella, Edward Smith, Thomas Stevens, William Stone, Chandler Swanberg, David Tague, Chandler Thompson, Edward Thode, Arun Walvakar, G. A. Whan, Katherine Wicks, Lee Wilson, Lee Woodward, Charles Young, Ramona Ytuarte, and James Zwerneman.

This project has been executed under a grant from the Lawrence Livermore Laboratory, the University of California, Livermore, California under subcontract number 4090109. 
.

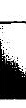

.

,

,

i

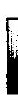


The objectives of the Environmental Overview for the Development of Geothermal Resources in the State of New Mexico project were:

1. to identify all existing environmental data in the state,

2. to identify where data relevant to determining the environmental impact of geothermal development are not presently collected,

3. to develop priorities of potential environmental issues associated with geothermal development in the state, and

4. to make recommendations for future environmental impact research programs within the state.

Statewide input for this document was solicited by the New Mexico Energy Institute at New Mexico State University and the New Mexico Environmental Institute through the participation of a statewide steering committee, the distribution of two draft documents for public comment, and the conducting of a two-day statewide overview workshop, prior to the completion of the final report.

At present, 56 known or potential hydrothermal resource sites and one hot, dry rock geothermal site have been identified in New Mexico. Eight KGRA's (Known Geothermal Resource Areas) and 12 KGRF's (Known Geothermal Resource Fields) have been established in the state. There are 13 hydrothermal resource areas with temperatures estimated at $150^{\circ} \mathrm{C}$ or greater with the potential for development of electrical generation facilities. Al1 56 hydrothermal sites, of course, have potential for development of a large array of direct heat geothermal applications. A detailed description of these geothermal resources and their potential for development is presented in this report.

The report provides a brief overview of the present day geothermal applications for hydrothermal electrical generation and direct heat use and their environmental implications. Technologies and environmental impacts are considered at all points on the pathway of development resource exploration; well field, plant and transmission ,line construction; and plant operation. The technologies for electrical generation-direct, dry steam conversion; separated steam conversion; single-flash conversion, separated-steam/single-flash conversion and binary cycle conversion and the technologies for direct heat use -direct use of geothermal waters, surface heat exhanger, down-the hole heat exchanger and heat pump are described. A summary of the geothermal technologies planned or in operation within New Mexico geothermal areas is provided.

Section 4.0 presents a review of regulations that affect geothermal development and its related environmental impact in New Mexico. The regulatory pathway, both state and federal, of geothermal exploration after the securing of appropriate leases, development, and construction and implementation of a geothermal facility are described.

Six categories (Geophysical, Water, Air, Noise, Biota and Socioeconomics) were selected for overview examination on the basis of 
their common appearance in environmental assessments and environmental impact statements associated with geothermal energy projects.

Section 5.0 describes the available information for assessing environmental impacts associated with geothermal development. Each subsection describes the type of data available, what agency or group is collecting the data, the collection frequency and level, the location of collection sites, and the degree of data accuracy available. Each subsection further describes the current monitoring activities of that data set in the state, and a projection of the accuracy of that baseline data in determining environmental impacts of geothermal development.

In general, the accuracy of environmental baseline data available for determining the impact of geothermal development may be summarized as follows:

Geophysical data, although of excellent quality, are general in nature. The data are insufficient to determine well placements and potential environmental impacts. Seismic data may be biased to the location of the monitoring stations. Subsidence data are not generally collected. In areas of the state where Soil Conservation Service surveys are complete, sufficient soil data should be available.

The accuracy of baseline surface and groundwater data is thought to be adequate for determination of environmental parameters, where such data exist. Data on water from geothermal reservoirs is conspicuously missing for most of the state. These data would usually be developed in the course of geothermal exploration and project development.

The accuracy of baseline air data, is excellent, where the air monitoring network exists and within the limits of the monitoring program. However, air monitoring units are conspicuously. missing for Catron county and in the vicinity of 36 additional geothermal sites. Other unit locations may not be close enough to monitor geothermal sites in the area. It is necessary to evaluate the completeness of available data in the vicinity of a particular site to determine the need for additional data collection activities. Further, although the state has standards for arsenic, beryllium, boron, hydrogen sulfide, hydrocarbons, heavy metals, total reduced sulfur, mercury, methane, ethane and fugitive dust, the air monitoring system does not provide any data on these air pollutants.

Baseline data for noise pollution and abatement are virtually non-existent in the state. Background noise data may be sufficiently established in Albuquerque and perhaps at the Baca and LASL geothermal development sites. Other cities with noise abatement regulations focus only on vehicular traffic noise data.

General information on the biota of the state exists and is available. Most information can be found in the Heritage Program data bank, or this data bank can be used to find out where data are to be obtained. Animal occurrence and range information is relatively well known for the vertebrates. Vegetation data is not sufficient at the community-type level. Vegetation surveys and inventories, will likely 
have to be conducted at each site of proposed development. Threatened and endangered species data are good enough to predict when extensive searches will be necessary.

Census data are generally adequate for basic socio-economic assessment. It may, however, not accurately represent all cultural groups in the area of a geothermal development. Availability of baseline data for archaeological and historical sites in New Mexico is no more than $10 \%$ complete in any area. Much of the state has been even less well surveyed. Site-specific surveys of planned disturbed areas in a geothermal resource area will probably be needed to establish adequate baseline data. Baseline data for measuring environmental impact on recreation areas and land use are accurate where it exists. The absence of growth projection data stem from the non-existence or regional comprehensive land use planning units.

Environmental impacts that may occur with the development of geothermal energy in New Mexico are divided into short-term, those generally associated with exploration, development and construction phases, and long-term, those generally associated with plant or facility operations. They are further described as impacts associated with the technologies of electrical generation and those associated with the technologies of direct heat applications where the degree of predicted impact differs.

Geophysical impacts are those of man-induced seismicity, subsidence and soil modification. The impacts of geothermal development that could occur in association with water are those related to the diversion of water from another use and the changing of water quality. Those impacts that could occur in association with air quality are the emission of air contaminents and visual degradation. Noise pollution stems from drilling and well testing activities and well venting and turbine operations. Biotic impacts are site and technology specific and are secondary, that is, the result of changes in the environment caused by other type of impacts. Socioeconomic changes may be issues, rather than impacts, that is, changes that may be determined by discussion and prior resolution rather than being the direct consequence of changes in the physical environmental elements of air, water, physical structures and biota.

Environmental impacts associated with geothermal development in New Mexico were ranked as "high" and "low" priority for general geothermal development. Individual impacts and issues may be more or less important to the development of specific geothermal sites and the type of development planned for the site. High priority impacts are in the areas of water and air quality and socioeconomic changes. Low priority impacts are in the categories of biotic, geophysical and noise.

Specific recommendations are made for actions to be taken in evaluating the significance of environmental impacts associated with geothermal development in New Mexico. Those recommendations in the six categories (Geophysical, Water, Air, Noise, Biota and Socioeconomic) are in two broad areas: research and data acquisition, and new legislation. 
ACKNOWLEDGEMENTS. . . . . . . . . . . . . . . . . . i ABSTRACT. . . . . . . . . . . . . . . . . . . . $i i i$

LIST OF TABLES. . . . . . . . . . . . . . . . . . . . . . v vx LIST OF FIGURES . . . . . . . . . . . . . . . . . . vXii

1.0 INTRODUCTION . . . . . . . . . . . . . . . . 1

1.1 Description of Geothermal Environmental Overview Project.................... 1

1.2 Major Objectives of the Project... . . . . . . . 1

1.3 Gathering Statewide Input into the Environmenta1 Overview Project. . . . . . . . . . . . . . 2

2.0 GEOTHERMAL RESOURCES IN NEW MEXICO ............ 5

2.1 Description of New Mexico Geothermal Resources. . . . 5

2.2 Potential Commercial Development of Geothermal Sites.................... 18

3.0 GEOTHERMAL TECHNOLOGICAL APPLICATIONS AND THEIR ENVIRONMENTAL. TMPLICATIONS . . . . . . . . . . . . . . . . . 25

3.1 Applications for Hydrothermal Electrical Generation . 25

3.1.1 Resource Exploration........... 25

3.1.2 We11 Field, Plant and Transmission Line Construction . . . . . . . . . . . . . 27

3.1.3 Plant Operation. . . . . . . . . . 28

3.1.3.1 Direct, Dry Steam Conversion Process. . 28

3.1.3.2 Separated Steam Conversion Process. . . 30

3.1.3.3 Single-Flash Conversion Process . . . 30

3.1.3.4 Separated-Steam/Single-Flash Conversion Process........... 34 
3.1.3.5 Binary Cycle Conversion Processes . . . 37

3.2 Applications for Direct Heat Use. . . . . . . . . 37

3.2.1 Resource Exploration ............ 39

3.2.2 Building and Heat Delivery System

Construction . . . . . . . . . . . . 39

3.2.3 Geothermal Systems Operation . . . . . . 39

3.2.3.1 Direct Use of Geothermal Waters . . . 39

3.2.3.2 Surface Heat Exchanger. . . . . . . 40

3.2.3.3 Down-the-Hole Heat Exchanger. . . . . 40

3.2.3.4 Heat Pump.... . . . . . . . . 40

3.3 Summary of Existing or Planned Geothermal

Technological Applications in New Mexico. . . . . . 40

3.3.1 Electrical Generation. . . . . . . . . 41

3.3.2 Direct Heat Applications . . . . . . . . 41

3.3.2.1 Space and Water Heating. . . . . . 41

3.3.2.2 Bath Houses and Bathing....... 43

3.3.2.3 Greenhouses ... . . . . . . . 43

3.3.2.4 Process Heat............ 43

4.0 REVIEW OF REgULATIONS THAT AFFECT GEOTHERMAL DEVELOPMENT AND ITS ENVIRONMENTAL IMPACT . . . . . . . . . . . . 45

4.1 Definition of a Geothermal Resource in New Mexico . . 45

4.2 Resource Exploration Phase. . . . . . . . . . 45

4.2.1 Regulation of Exploration We11s........ 46

4.2.2 Regulation of Surface and Groundwaters . . . 49

4.2.3 State Archeologist Regulations ....... . 50

4.2.4 Pathway to Geothermal Exploration in New

Mexico................ 50

4.3 Resource Development Phase. . . . . . . . . . . 52 
4.3.1 Regulation of Development Wells....... 52

4.3.2 Regulation of Surface and Groundwaters . . . 53

4.3.2.1 Water Quantity. . . . . . . . 53

4.3.2.2 Water Quality........... 58

4.3.3 Regulations for Establishment of a Public
Utility. . . . . . . . . . . 60

4.3.4 Pathway to Development of a Geothermal

Resource Area in New Mexico. . . . . . . 60

4.4 Construction and Implementation Phase . . . . . . . 62

4.4.1 Local Zoning Codes... . . . . . . . . 62

4.4.2 Construction Industries Commission Building

Codes . . . . . . . . . . . 63

4.4.3 Environmental Improvement Division Air
Quality Regulations........... 63

4.4.4 Other Federal Regulations. . . . . . . . 69

4.4.5 Environmental Improvement Division

Special Permits............ . 69

4.4.6 Pathway for Construction and Implementation

for a Geothermal Facility in New Mexico. . . . 69

4.5 Operations Phase................. . 71

4.5.1 Hazardous Waste Regulations. . . . . . . 71

4.5.2 On-Going Record Keeping and Reporting .... it

4.5.2.1 State and Loca1 Requirements. . . . . 71

4.5.2.2 Federal Requirements........ . 72

4.5.3 Pathway for Operation of a Geothermal

Facility in New Mexico... . . . . . . 72

5.0 AVAILABLE INFORMATION FOR ASSESSING ENVIRONMENTAL IMPACTS ASSOCIATED WITH GEOTHERMAL DEVELOPMENT . . . . . . . . . . 75

5.1 Geophysical Data. . . . . . . . . . . . 75

5.1.1 Description and Measurement. . . . . . . 75 
5.1.1.1 Distribution of Thermal Waters. . . . 75

5.1.1.2 Heat Flow Measurements. . . . . . 78

5.1.1.3 Deep Sedimentary Basins...... . 78

5.1.1.4 Quaternary Volcanic Rocks, Volcanic Centers, Quaternary and Other Tertiary

Fau1ts. . . . . . . . . . . 78

5.1.1.5 Seismicity. . . . . . . . . 78

5.1.1.6 Subsidence. ........... 78

5.1.1.7 Soils............... 78

5.1.2 Current Monitoring Activities. . . . . . 85

5.1.2.1 Thermal Waters, Heat Flow, Sedimentary

Basins, Quaternary Structures and

Faults, and Seismicity. . . . . 85

5.1.2.2 Subsidence. . . ........ 85

5.1.2.3 Soils.............. 88

5.1.3 Accuracy of Baseline Data. . . . . . . . 88

5.2 Water Data. . . . . . . . . . . . . 88

5.2.1 Description and Measurement. . . . . . . 90

5.2.1.1 General .............. 90

5.2.1.2 Quantity of Water.......... . 90

5.2.1.3 Quality of Water. . . . . . . . 95

5.2.1.3.1 Surface and Groundwaters... . 95

5.2.1.3.2 Geotherma1 Waters....... . 98

5.2.2 Current Monitoring Activities. . . . . . . . 99

5.2.2.1 Quantity of Water.......... 99

5.2.2.2 Quality of Water.......... 101

5.2.3 Accuracy of Baseline Data. . ....... 107

5.3 Air Data. . . . . . . . . . . . . . 108

5.3.1 Description and Measurement. . ...... 109 
5.3.2 Current Monitoring Activities. . . . . . 110

5.3.3 Accuracy of Baseline Data. . . . . . . . 112

5.4 Noise and Noise Pollution Data. . . . . . . . . 114

5.4.1 Description and Measurement. . . . . . . 114

5.4.2 Current Monitoring Activities. . . . . . . 115

5.4.3 Accuracy of Baseline Data. . . . . . . . 115

5.5 Biotic Data . . . . . . . . . . . . . 118

5.5.1 Description and Measurement. . . . . . . 118

5.5.1.1 Flora............... . 118

5.5.1.1.1 Vegetation......... 118

5.5.1.1.2 Threatened and Endangered

Species. . . . . . . . 121

5.5.1.2 Fauna.............. 121

5.5.1.2.1 Anima1 Communities . . . . . 121

5.5.1.2.2 Threatened and Endangered

Species.......... 121

5.5.2 Current Monitoring Activities. . . . . . . 124

5.5.3 Accuracy of Baseline Data. . . . . . . . 124

5.6 Socioeconomic Data. . . . . . . . . . . . . . 124

5.6.1 General Socioeconomic Data......... 124

5.6.1.1 Description and Measurement . . . . 124

5.6.1.2 Current Monitoring Activities . . . . 127

5.6.1.3 Accuracy of Baseline Data . . . . . 127

5.6.2 Archaeological and Historical Sites. . . . . 127

5.6.2.1 Description and Measurement . . . . 127

5.6.2.2 Current Monitoring Activities . . . . 129

5.6.2.3 Accuracy of Baseline Data . . . . . 129

5.6.3 Recreation................. 134 
5.6.3.1 Description and Measurement..... 134

5.6.3.2 Current Monitoring Activities... . . 134

5.6.3.3 Accuracy of Base1ine Data. . . . . 137

5.6.4 Land Use... . . . . . . . . . . 137

5.6.4.1 Description and Measurement . . . . 137

5.6.4.2 Current Monitoring Activities... . . 141

5.6.4.3 Accuracy of Baseline Data. . . . . 141

6.0 PREDICTED ENVIRONMENTAL IMPACTS. . . . . . . . . . . 145

6.1 Geophysical Impacts................ 145

6.1.1 Short-Term Impacts . . . . . . . . . . 145

6.1 .2 Long-Term Impacts. . . . . . . . . . . . 146

6.2 Water Impacts . . . . . . . . . . . . . 148

6.2.1 Short-Term Impacts............ 148

6.2.2 Long-Term Impacts. . . . . . . . . . . 149

6.3 Air Impacts . . . . . . . . . . . . . . 150

6.3.1 Short-Term Impacts............ 150

6.3.2 Long-Term Impacts. . . . . . . . . . . 151

6.4 Noise Impacts . . . . . . . . . . . . . . 152

6.4.1 Short-Term Impacts . . . . . . . . . . 152

6.4.2 Long-Term Impacts. . . . . . . . . . 153

6.5 Biotic Impacts. . . . . . . . . . . . . . 153

6.5.1 Short-Term Impacts . . . . . . . . . 153

6.5.2 Long-Term Impacts. . . . . . . . . . . 154

6.6 Socioeconomics Impacts. . . . . . . . . . . 154

6.6.1 Short-Term Impacts . . . . . . . . . . 154

6.6.2 Long-Term Impacts. . . . . . . . . . . 155 
7.0 RECOMMENDATIONS AND CONCLUSION . . . . . . . . . . 159

7.1 Ranking of Environmental Impacts. . . . . . . . . 159

7.1.1 High Priority Impacts. . . . . . . . . 159

7.1.2 Low Priority Impacts . . . . . . . . . 160

7.2 Recommendations for Specific Actions to be Taken in Evaluating the Significance of Environmental Impacts Associated with Geothermal Development....... 161

7.2.1 Geophysical. . ............. 161

7.2.1.1 Research and Data Acquisition..... 161

7.2.1.2 Regulations and New Legislation.... 161

7.2.2 Water. . . ............. 162

7.2.2.1 Research and Data Acquisition . . . 162

7.2.2.2 Regulations and New Legislation.... 162

7.2 .3 Air. . . . . . . . . . . . . 163

7.2.3.1 Research and Data Acquisition . . . 163

7.2.3.2 Regulations and New Legislation . . . 163

7.2 .4 Noise. . . . . . . . . . . . . . 164

7.2.4.1 Research and Data Acquisition . . . . 164

7.2.4.2 Regulations and New Legislation . . . 164

7.2.5 Biota. . . . . . . . . . . . 164

7.2.5.1 Research and Data Acquisition . . . . 164

7.2.5.2 Regulations and New Legislation . . . 164

7.2.6 Socioeconomic. . . . . . . . . . 165

7.2.6.1 Research and Data Acquisition.... . 165

7.2.6.2 Regulations and New Legislation... 165

7.3 General Summary Comments. . . . . . . . . . 165 
REFERENCES. . . . . . . . . . . ...... 167

APPENDIX A -- STEERING COMMITTEE MEMBERS. . . . . . . . . . . 189

APPENDIX B -- LIST OF PEORLE INVITED TO WORKSHOP AND ATTENDEES . . . . . . . . . . . . . . . 191

APPENDIX C - - AGENDA FOR THE WORKSHOP FOR AN ENVIROMMENTAL OVERVIEW FOR THE DEVELOPMENT OF GEOTHERMAL RESOURCES IN THE STATE OF NEW MEXICO. . . . . . 207

APPENDIX D -- GLOSSARY. . . . . . . . . . . . . . 211

APPENDIX E -- GENERAL SOCIOECONOMIC INFORMATION BY NEW MEXICO COUNTY. . . . . . . . . . . . . . . 229

APPENDIX F -- AVAILABLE ENVIRONMENTAL INFORMATION FOR GEOTHERMAL SITES IN NEW MEXICO. . . . . . . . . . . . 247 
Table

1. Identification of individual hydrothermal sites in

New Mexico. . . . . . . . . . . . . . . . .

2. Estimated reservoir temperatures, volumes and amount of beneficial energy available in New Mexico for

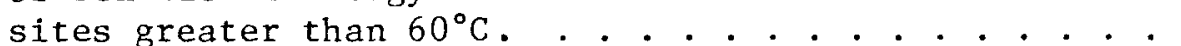

3. A brief summary of hydrothermal resource data. . . . .

4. A sumary of commercial activity in New Mexico high and low temperature geothermal resource areas. . . . . .

5. Market output for geothermal resource areas in New Mexico. . . . . . . . . . . . . . . . . . . .

6. Average chemical analysis of geothermal steam (without scrubbing) for the $50 \mathrm{MW}_{\mathrm{e}}$ Baca Power Plant. . . . . .

7. Geothermal technologies planned or in operation within New Mexico geothermal resource areas. . . . . .

8. Definition, unit of measurement, and state and federal regulations concerning air pollutants that may possibly be associated with geothermal development. . . . . . . . . . . . . . . . .

9. Monitoring frequency and coverage of air pollutants that may be associated with geothemal development. . .

10. Examples of wel1-known sources of sound. . . . . . .

11. Sound levels from various noise sources at the Geysers, California geothermal electrical generation facility. .

12. General socioeconomic information about the State of New Mexico. . . . . . . . . . . . . . . . . . . 
$x v i$ 
Figure

1. Geothermal resource areas in New Mexico currently identified for the Department of Energy Regional

Operations Program and related KGRA's.:. . . . . . . .

2. Geothermal resource areas in New Mexico and related Known Geothermal Resource Fields (KGRE's). . .

3. Subsurface temperatures estimated by the silica geothermometer in relation to geothermal sites in New Mexico.. . . . . . . . . . . . . . .

4. Subsurface temperatures estimated by the sodiumpotassium-calcium geothermometer in relation to geothermal sites in New Mexico. . . . . . . . . . . .

5. Total dissolved solids (TDS) in relation to geothermal sites in New Mexico. . . . . . . . . . . .

6. Typical equipment layout at a geothermal exploration well. . . . . . . . . . . . . . . . . .

7. A schematic diagram for the direct dry steam (DDS) energy conversion process.

8. A schematic diagram for the separated steam (SS) energy conversion process. . . . . . . . . . . . .

9. A schematic diagram for the single-flash (SF) energy conversion process.

10. A schematic diagram of the single-flash power system designed for the 50 MW electrical generation facility in the Baca. . . . . . . . . . . . . . . . . .

11. A schematic diagram for the separated-steam/singleflash (SSSF) conversion process. . . . . . . . . . .

12. A schematic diagram of a binary cycle conversion process. . . . . . . . . . . . . . . . .

13. Time line and events chart of institutional procedures for exploration of geothermal resources in New Mexico under state and local regulations and of the EIS process. . . 


\section{LIST OF FIGURES (Continued)}

Figure

14. Time line and events chart of institutional procedures for development of geothermal resource area in New Mexico under state and local regulations and of the EIS process.

15. Mandatory Class I, under the Prevention of Significant Deterioration and the Visibility Protection sections of the 1977 Clean Air Act in New Mexico. . . . . . .

16. Time line and events chart of institutional procedures for construction and implementation for geothermal facility in New Mexico under state and local regulations and of the EIS process. . . . . . . . . . .

17. Time line and events chart of institutional procedures for operation of a geothermal facility in New Mexico under state and local regulations and federal environmental monitoring. . . . . . . . . . . . . . .

18. Distribution of water, oil and gas wells having abnormally high bottom hole temperatures in relation to geothermal sites in New Mexico. . . . . . . . .

19. Distribution of thermal wells and springs in relation to geothermal sites in New Mexico. . . . . . . . . . 77

20. Heat flow contour map in relation to geothermal sites in New Mexico. . . . . . . . . . . . . . . . . . .

21. Deep sedimentary basins relative to major geothermal sites in New Mexico. . . . . . . . . . . . . . .

22. Location of late Quaternary volcanic rocks, faults and major volcanic centers in relation to geothermal sites in New Mexico.

23. Seismic activity ("fe1t earthquakes") prior to the installation of a regional seismic monitoring network in 1962 in relation to geothermal sites in New Mexico. .

24. Recorded seismic activity between 1962 and 1967 in relation to geothermal sites in New Mexico. . . . . . . .

25. Recorded seismic activity between 1968 and 1977 in relation to geothermal sites in New Mexico. . . . . . . 


\section{LIST OF FIGURES (Continued)}

Figure

26. Availability of soil classification data from the Soil Conservation Service and Forest Service in relation to geothermal sites in New Mexico. . . . . . .

27. Availability of soil classification data from the New Mexico Agricultural Experiment Station in relation to geothermal sites in New Mexico . . . . . . . . .

28. Twenty-five declared underground water basins in New Mexico. . . . . . . . . . . . . . . . .

29. Locations of groundwater studies in 1973, divided into quantitative, qualitative and reconnaissance work. . . .

30. Mean discharge of selected reaches of streams, in cubic feet per second and mean annual runoff, in inches, in New Mexico, 1951-1970. . . . . . . . . . . . .

31. Location of USGS streamflow-gaging stations in New Mexico in 1970. . . . . . . . . . . . . . . . .

32. Surface water drainage basins monitoring sites in New Mexico. . . . . . . . . . . . . . . . .

33. Location of USGS chemical quality and suspended sediment sampling stations in New Mexico, 1970. . . . . . . . . .

34. Average annual dissolved solids discharge in selected reaches of streams and dissolved solid discharge at selected stations in New Mexico, 1951-1970.

35. Average annual suspended sediment discharge in selected reaches of streams and suspended sediment discharge at selected stations in New Mexico, 1951-1970.

36. Air quality control regions and ambient air monitoring units for the State of New Mexico. . . . . . . . . . . .

37. General vegetation patterns in New Mexico. . . . . .

38. Key wildlife ranges. . . . . . . . . . . . 122

39. Wildlife management areas. ............ 123

40. Wilderness areas. . . . . . . . . . . . 125 
41. Natural areas. . . . . . . . . . . . . . 126

42. Predicted density of archaeological sites. . . . . . . 130

43. Known archaeological site densities. . . . . . . . 131

44. Registered historic sites. . . . . . . . . . . 132

45. Religious shrines, ................ . 133

46. Parks and monuments. . . . . . . . . . . . 135

47. Wild and scenic rivers. . . . . . . . . . . . . . 136

48. Potential growth areas. . . . . . . . . . . . . 138

49. Existing irrigated agricultural lands. . . . . . . . 139

50. Areas without fresh water aquifers. . . . . . . . . 140

51. Mineral occurrences, . . . . . . . . . . . . 142

52. Prime and secondary range land. . . . . . . . . . 143

53. Commercial timber industry locations. . . . . . . . . . . 144 


\subsection{INTRODUCTION}

\subsection{Description of the Geothermal Environmental Overview Project}

As geothermal resources are located and tapped for their energy reserves throughout the United States, it will become increasingly important to identify and understand the possible environmental impacts of geothermal energy development prior to commercial development. These impacts, both positive and negative, need to be compared with those of other energy forms in the national energy program.

In order to initiate a base level of understanding concerning the environmental issues that arise from geothermal development, the Lawrence Livermore Laboratory, Livermore, California, has conducted overview projects covering geothermal regions in California. Under subcontract, similar projects were carried out at geothermal regions in California and Utah. This program also includes statewide programs in portions of the Geothermal Regions I and II.

The Environmental Overview for the Development of Geothermal Resources in the State of New Mexico was conducted by the New Mexico Environmental Institute and the New Mexico Energy Institute at New Mexico State University. The overview program resulted in a detailed report of potential environmental issues related to the development of the state's fifty-six known or potential geothermal areas, the associated eight Known Geothermal Resource Areas (KGRA's) and 12 known Geothermal Resource Fields (KGRF's) and, to a lesser degree, the hot dry rock geothermal area near Fenton Lake, New Mexico. Although other potential geothermal resources are indicated in the list of hydrothermal springs and wells in New Mexico in the U.S. Geologic Survey File GEOTHERM (Hanny and Lumis, 1979), these resources are not sufficiently documented to be included in the present project work.

The inclusion of fifty-seven geothermal sites and an array of possible geothermal technology applications in this overview project precludes in-depth discussion of any single site. The overview is intended to provide the Department of Energy with a pre-planning study to identify environmental issues, inventory the information available about them, specify data gaps and propose studies to develop the necessary information.

\subsection{Major Objectives of the Project}

The four major objectives of the Environmental Overview project were:

1. to identify all existing environmental data that are available in the state through state and federal entities and within the universities; 
2. to identify where data relevant to determining the environmental impact of geothermal development are not presently collected;

3. to develop priorities of the potential environmental issues for each geothermal site and the array of technology that might be applied to it through development activities; and

4. to make recommendations for future environmental impact research programs within the state.

\subsection{Gathering Statewide Input into the Environmental Overview Project}

The number of potential geothermal sites and their broad distribution throughout New Mexico increases the potential for wide-spread environmental impact within major portions of the state, particularly central and western New Mexico. Consequently, the New Mexico Energy Institute at New Mexico State University and the New Mexico Environmental Institute have sought statewide participation in formulating an environmental overview for geothermal development.

A statewide Environmental Overview Steering Committee (Appendix A) was formed in January 1979. It included key participants in state and federal agencies that currently have a regulatory function in geothermal development and environmental issues and consumer and utility representatives that have an interest in future geothermal development within the state. This committee was instrumental in accessing baseline data for the project staff and serving as a review group to the overview program.

Two draft overview documents, predecessors to the final project report were prepared for the purpose of soliciting public input for the final report. Input to the second draft document was solicited from participants in the Geothermal Environmental Overview Workshop held in Albuquerque, New Mexico, September 7 and 8, 1979 (Appendix B).

At the workshop Marilyn Marquis of the Albuquerque Department of Energy Geothermal Project office read the following statement on behalf of Ruth Clusen, Assistant Secretary for the Environment, Department of Energy:

In review, the nation's experience with the development of energy sources, one fact becomes painfully clear-it is risky business to undertake any development program without some mechanism to address environmental, health and safety concerns associated with such development. The environmental risk involved has manifested itself in costly court battles and other protest activities by organized environmental groups which frequently led to a slowdown or stoppage of much needed projects at great expense to the nation as a whole. How did this risk factor develop? 
It appears that fear (real or imagined) that some major projects would cause serious adverse consequences for the environment or the health and safety of the public is the root cause of the risk factor. Some of the contributing causes of that fear would appear to be:

- Lack of an adequate data base. In many cases, adequate information has not been developed or is not available in a form suitable for assuring decision-making groups that the impact of development is known.

- Inadequate mechanism for information dissemination. Even in those cases where adequate information exists, ways to get that information to groups who share in the decision-making process frequently do not exist.

- Lack of a systematic means of involving decision-making groups in the early identification of environmental concerns. No such means have existed heretofore despite some "hit and miss" efforts in that direction.

The basic assumption of the Geothermal Overview Project is that if all decision-making groups were involved early in the planning process for geothermal development and had access to adequate information on environmental issues and their proposed resolution, much of the environmental uncertainty associated with development would be reduced or eliminated. Such involvement would be expected to lead to 1) assigninent of development priorities, including "go/no-go" judgements; 2) clearer guidelines and regulations for development; and 3) early identification to developers of the environmental risks associated with development.

The Geothermal Environmental Overview Project was developed by the Assistant Secretary for Environinent as a mechanism to assure that regional decision-making groups would be identified and involved in the development of a comprehensive environmental data base prior to the initiation of any large scale geothermal development. Because geothermal energy is a regional specific energy source, the rationale for these activities is that regional involvement will lead to the development of a consensus view on the environmental viability of geothermal development in any target region.

Today you will hear a lot about the geothermal environmental overview approach and how it is being applied in New Mexico. This workshop represents a key feature in that approach. We at DOE hope that this workshop will produce the beginning of a regional environmental data base on which future geothermal development decisions can be made. We are confident that your full participation will help achieve that objective. 
Over 165 people from around New Mexico and from other interested states and federal groups were invited to attend the workshop to review the presentation of project data, identify the possible environmental impacts that might be associated with geothermal development in the state, and make recommendations for site-specific environmental assessment programs that may follow the overview project recommendations. There were 60 attendees at the two-day workshop in Albuquerque, New Mexico. Recommendations of this group are included in this, the overview project's final report. 
At present, 56 known or potential hydrothermal resource sites and one hot, dry-rock geothermal site have been identified in Nerv Mexico (Figure 1). The majority of these sites lie within the Rio Grande Rift with the remaining sites located within the Basin and Range, Colorado Plateau and Southern Rockies Provinces (USGS, 1978). Additional hydrothermal springs and wells are identified in the USGS File GEOTHERM. These are not yet sufficiently documented to be included in this project's current work. It is assumed, however, that the data and issues discussed in this overview report are, at least in part, applicable to newly identified resource areas or newly established Known Geothermal Resource Areas (KGRA's) and Known Geothermal Resource Fields (KGRF's).

\subsection{Description of New Mexico Geothermal Resources}

Eight Known Geothermal Resource Areas (KGRA's) have been established in relation to several of the identified geothermal sites (Figure 1). They are the Baca Location No. 1 (Site 01), Lightning Dock (02), Lower San Francisco Hot Springs (03), Kilbourne Hole (04), Radium Springs (08), Gila Hot Springs (10, 11, and 13), San Ysidro (37) and Socorro Peak (55).

The 12 Known Geothermal Resource Fields (KGRF's) have been established by the New Mexico Land Office (Kennedy, 1979). They are illustrated in Figure 2.

Baca Location No. 1. KGRA is being commercially developed by Union Geothermal Company of New Mexico and Public Service Company of New Mexico. A $50 \mathrm{MW}$ Department of Energy/industry-funded demonstration generating plant facility is expected to be "on line" by 1982. U.S.G.S. Circular 790 (1978) identifies the valles Caldera (01) as the only confirmed hot-water hydrothermal convection system with a temperature greater than $150^{\circ} \mathrm{C}$. Unconfirmed hydrothermal sites (Marlin et al., 1978) with temperatures estimated at $150^{\circ} \mathrm{C}$ or greater include Lightning Dock" (02), Kilbourne Hole (04), Las Alturas (16), Closson (27), Crown Point (33), Prewitt Northeast (34), Guadalupe Area (51), Colunbus Area (52), Tularosa Basin South (54), Socorro Peak (55), Jemez Reservoir (56), and Lordsburg (57).

Hydrothermal sites (Marlin et al., 1978) with estimated temperatures of $90^{\circ} \mathrm{C}$ to less than $150^{\circ} \mathrm{C}$ are Lower San Francisco Hot Springs (03), Radium Springs (08), 0jo Caliente (09), Montezuma Hot Springs (12), Mamby Hot Springs (14), White Sands Missile Range (15), Berino-Mesquite (18), Ponce, de Leon (20), Truth or Consequences (24), Black Mountain (26), Playas Valley (28), Derry Warm Springs (30), Guadalupe Spring (35), Hot We11 (36), San Ysidro (37), Aleman (44), San Diego Mountain (53), Lordsburg (57), Jicarilla Apache Indian Reservation (64) and Little Blue Mesa (65). Fourteen other hydrothermal sites have temperatures estimated at less than $90^{\circ} \mathrm{C}$. 


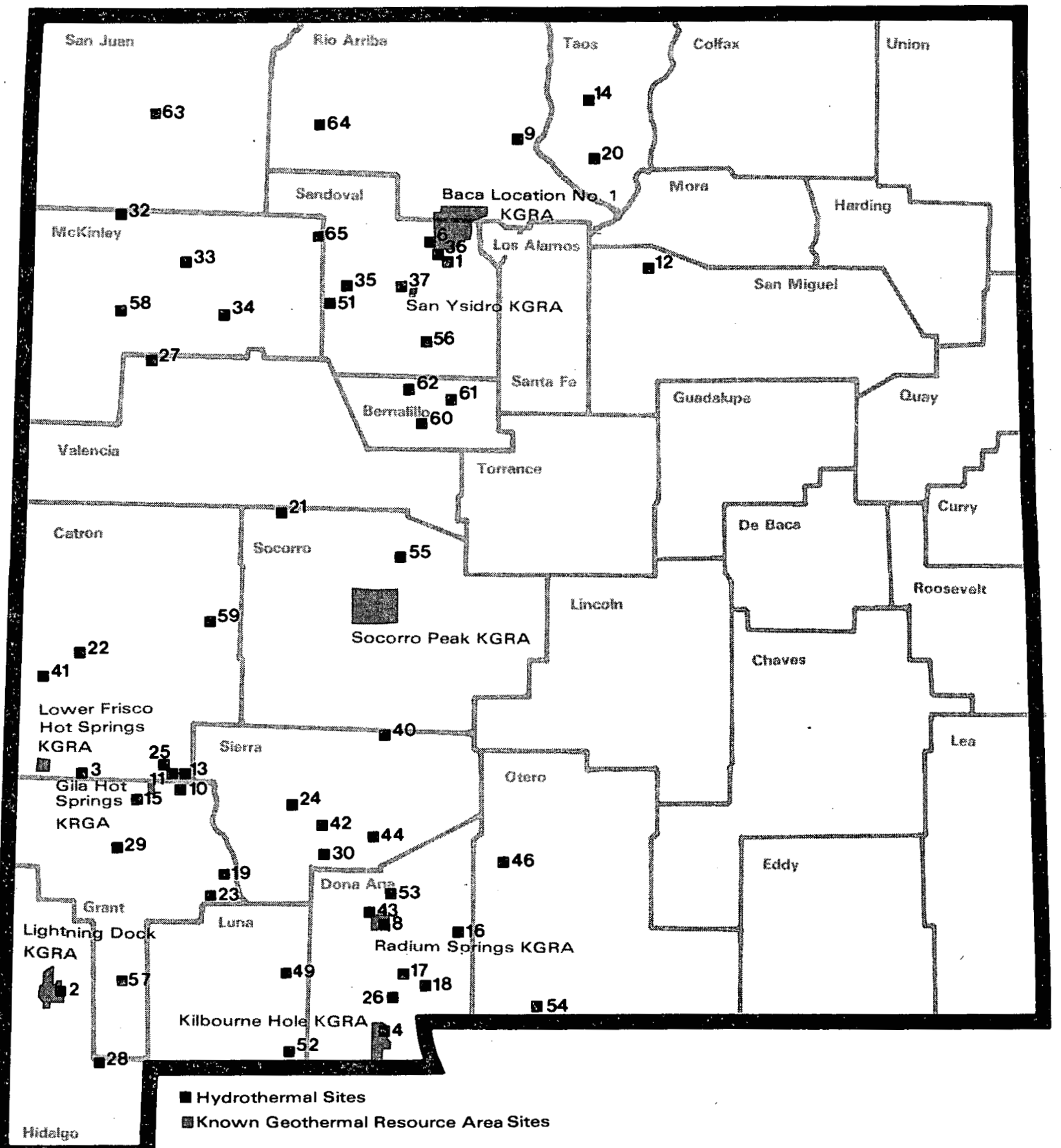

Figure 1. Geothermal resource areas ${ }^{1}$ in New Mexico currently identified for the Department of Energy Regional Operations Program and related KGRA's (Marlin et al., 1978).

$I_{\text {The site numbering, system used here and elsewhere in this }}$ document is not consecutive, but is consistent with the site identification system of the Geothermal Regional Operations Research Program. 


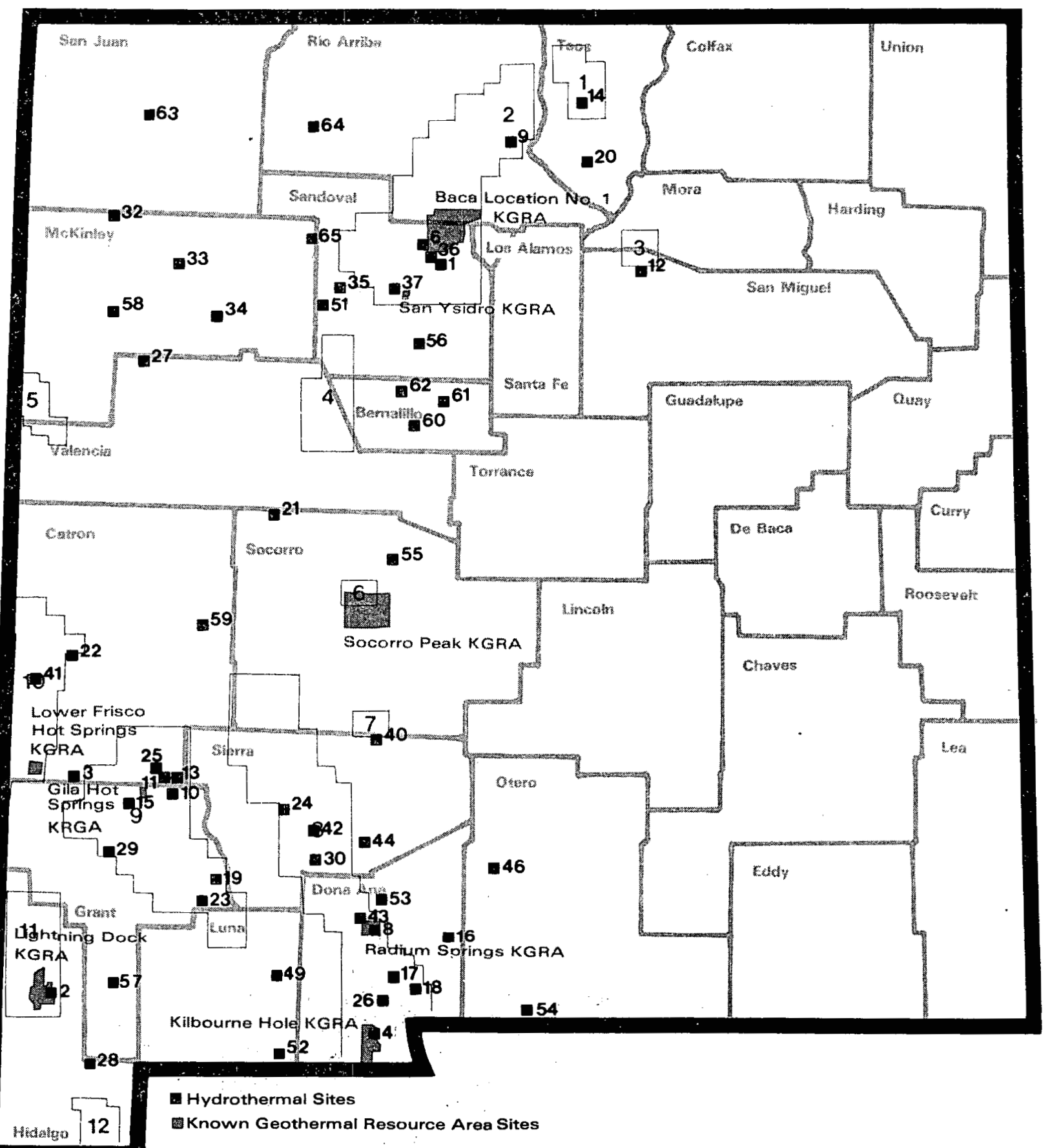

Figure 2. Geothermal resource areas in New Mexico and related Known Geothermal Resource Fields (KGRF's) (Kennedy, 1979). 
Table 1 identifies the 56 hydrothermal sites by county, latitude and longjtude (Marlin et al., 1978).

A hot dry rock geothermal resource area is situated near Fenton Lake, New Mexico, within the Baca \#1 KGRA (Figure 1) Los Alamos geophysical exploration to determine the potential of this and other hot dry rock resources. LASL has also constructed a thermal test loop involving two wells to the resource; surface water is pumped through fractures in the hot rock, heated, and returned to the surface through the production well (Brown et al., 1979).

Hydrothermal reservoir confirmation drilling activity has been limited in the geothermal sites in New Mexico, and consequently, there is little public knowledge (excluding propriatory data from industry) about confirmed reservojir temperatures and volumes or the chemical makeup of geothermal brines. Table 2 lists the estimated reservoir temperatures, volumes and amounts of beneficjal energy available (Marlin et al., 1979).

The geothermal resources of Valles Caldera (01) (Baca EIS, 1979) consist of two geothermal systems. The major reservoir is an overpressured liquid-dominated system containing on the order of $1.8 \mathrm{x}$ $10^{12} \mathrm{~kg}\left(4.7 \times 10^{12} \mathrm{lb}\right)$ of hot water, extending over an area of $100 \mathrm{~km}^{2}$ (40 square miles). The average reservoir fluid temperature is in excess of $260^{\circ} \mathrm{C}\left(500^{\circ} \mathrm{F}\right)$. The primary production-injection zone is the lower half of the Bandelier Tuff; the pumaceous basal $305 \mathrm{~m}$ of the Bandelier is the best production zone. The upper part of the Bandelier Tuff is very densely welded and forms the reservoir cap rock. The potential source of the fluids is thought to be the underlying Tertiary sands; the fluid can migrate upward to shallower zones under the Redondo Creek area, where the associated graben faults act as conduits. The results of well testing have confirmed a $50 \mathrm{ME}_{\mathrm{e}}$ energy supply and indicate that the fluid energy of the reservoir may be capable of supplying $400 \mathrm{MW}_{e}$ for 30 years (Baca EIS, 1979). The. second geothermal system is potentially a vapor-dominated system and probably overlies the liquid-dominated reservoir in Baca wells 4,11 , and 15 . The extent of this steam system is not known; however, it appears to trend to the northwest. The Baca KGRA contains lands held predominantly by the Baca Land and Cattle Company and Dunigan Enterprises (96\%, private ownership) with U.S. Forest Service and National Park Service (4\%, Bandelier National Monument) and the Los Alamos Ski Club (less than 1\%, private ownership) making up the remaining portions.

The geothermal resource of Lightning Dock probably consists of a 1iquid-dominated system, although a vapor-dominated system may also exist (Marlin et al., 1978, "well struck steam at 88 feet"). The reservoir temperature from geothermetric data indicates a subsurface fluid temperature of $170^{\circ} \mathrm{C}$ (Marlin et al., 1978). Land ownership is state, federal and private.

The resource of Kilbourne Hole would appear to be a liquid-dominated system. The reservoir temperature from geothermetric 
Table 1. Identification of individual hydrothermal sites in New Mexico (Marlin et a7,, 1978).

$\underline{\text { ID }}$

$$
\text { SITE NAME }
$$

COUNTY

LATITUDE

(Degrees)

LONGITUDE

(Degrees)

$\begin{array}{ll}01 & \text { Valles Caldera } \\ 02 & \text { Lightning Dock } \\ 03 & \text { Lwr San Francisco } \\ 04 & \text { Kilbourne Hole } \\ 06 & \text { Jemez Springs } \\ 03 & \text { Radium Springs } \\ 09 & \text { Ojo Caliente } \\ 10 & \text { Gila Hot Spring } \\ & \text { Below Bridge } \\ 11 & \text { Gila Hot Spring } \\ & \text { Middle Fork } \\ 12 & \text { Montezuma Hot } \\ & \text { Spring } \\ 13 & \text { Gila Hot Spring } \\ & \text { Doc Campbell } \\ 14 & \text { Mambys Hot Spring } \\ 15 & \text { Turkey Creek } \\ 16 & \text { White Sands } \\ & \text { Missile Range } \\ 17 & \text { Las Alturas } \\ 18 & \text { Berino-Mesquite } \\ 19 & \text { Mimbres Hot } \\ & \text { Spring } \\ 20 & \text { Ponce de Leon } \\ 21 & \text { San Augustin } \\ 22 & \text { Plain E } \\ \text { Upper San Fran- } & \text { cisco HS } \\ 23 & \text { Faywood HS } \\ 24 & \text { Tor C } \\ 25 & \text { Gila HS UMF } \\ 26 & \text { Black Mtn W Mesa } \\ 27 & \text { Closson } \\ 28 & \text { Playas Valley } \\ & \text { Pal }\end{array}$

$\begin{array}{lll}\text { Sandoval } & 35.883 & 106.533 \\ \text { Hidalgo } & 32.150 & 108.833 \\ \text { Catron } & 33.250 & 108.783 \\ \text { Dona Ana } & 31.967 & 106.950 \\ \text { Sandoval } & 35.783 & 106.683 \\ \text { Dona Ana } & 32.500 & 106.933 \\ \text { Rio Arriba } & 36.300 & 106.050 \\ \text { Grant } & 33.167 & 108.167 \\ \text { Catron } & 33.233 & 108.233 \\ & & \\ \text { San Miguel } & 35.650 & 105.283 \\ & & \\ \text { Catron } & 33.200 & 108.217 \\ & & \\ \text { Taos } & 36.533 & 105.683 \\ \text { Grant } & 33.117 & 108.483 \\ \text { Dona Ana } & 32.500 & 106.383 \\ \text { Dona Ana } & 32.250 & 106.767 \\ \text { Dona Ana } & 32.167 & 106.667 \\ \text { Grant } & 32.750 & 107.833 \\ & & \\ \text { Taos } & 36.317 & 105.617 \\ \text { Socorro } & 34.683 & 107.550 \\ \text { Catron } & 33.833 & 108.800 \\ \text { Grant } & 32.550 & 108.000 \\ \text { Sierra } & 33.133 & 107.050 \\ \text { Catron } & 33.283 & 108.283 \\ \text { Dona Ana } & 32.133 & 106.867 \\ \text { Valencia } & 35.267 & 108.317 \\ \text { Hidalgo } & 32.883 & 108.553 \\ & & \end{array}$


Table 1. Continued.

\begin{tabular}{|c|c|c|c|}
\hline SITE NAME & COUMTY & $\begin{array}{l}\text { LATITUDE } \\
\text { (Degrees) }\end{array}$ & $\begin{array}{l}\text { LONGITUDE } \\
\text { (Degrees) }\end{array}$ \\
\hline Cliff Area & Grant & 32.883 & 108.583 \\
\hline Derry Warm Spring & Sierra & 32.800 & 107.283 \\
\hline Tohatchi Area & McKinley & 35.917 & 108.583 \\
\hline Crown Point & Mckinley & 35.700 & 108.133 \\
\hline Prewitt NE & Mckinley & 35.433 & 107.883 \\
\hline Guadalupe Spring & Sandoval & 35.600 & 107.133 \\
\hline Hot Well & Sandoval & 35.750 & 106.667 \\
\hline San Ysidro & Sandoval & 35.583 & 106.833 \\
\hline Crocker & Sierra & 33.450 & 106.900 \\
\hline Freiborn Canyon & Catron & 33.700 & 109.033 \\
\hline Las Palomas & Sierra & 33.050 & 107.300 \\
\hline Rincon East & Dona Ana & 32.533 & 107.033 \\
\hline Aleman & Sierra & 32.983 & 107.033 \\
\hline Garton Well & Dtero & 32.783 & 106.167 \\
\hline Carne & Luna & 32.250 & 107.583 \\
\hline Guadalupe Area & Sandoval & 35.500 & 107.250 \\
\hline Columbus Area & Luna & 31.800 & 107.500 \\
\hline San Diego Mtn & Dona Ana & 32.633 & 106.967 \\
\hline $\begin{array}{l}\text { Tularosa Basin } \\
\text { South }\end{array}$ & Otero & 32.083 & 106.083 \\
\hline Socorro & Socorro & 34.333 & 106.833 \\
\hline Jemez Reservoir & Sandoval & 35.333 & 106.667 \\
\hline Lordsburg & Grant & 32.233 & 108.517 \\
\hline Fort Wingate & Mckinley & 35.500 & 108.583 \\
\hline $\begin{array}{l}\text { San Augustine } \\
\text { Plain }\end{array}$ & Catron & 34.017 & 108.100 \\
\hline Isleta & Bernal illo & 34.933 & 106.733 \\
\hline Al buquerque & Bernal illo & 35.083 & 106.633 \\
\hline Laguna & Bernalillo & 35.167 & 106.867 \\
\hline Mancisco Mesa & San Juan & 36.477 & 108.021 \\
\hline $\begin{array}{l}\text { Jicarilla Apache } \\
\text { Indian }\end{array}$ & Rio Arriba & 36.341 & 107.310 \\
\hline $\begin{array}{l}\text { Reservation } \\
\text { Little Blue Mesa }\end{array}$ & Mckinley & 35.856 & 107.333 \\
\hline
\end{tabular}


Table 2. Estimated reservoir temperatures, volumes and amount of beneficjal eneray available in New Mexico for sites greater than $60^{\circ} \mathrm{C}$ (Marjin et al., T978).

\begin{tabular}{|c|c|c|c|c|c|c|}
\hline SITE & SITE NAME & $\begin{array}{l}\text { VOLUME } \\
\left(\mathrm{KM}^{3}\right) \\
\end{array}$ & MWE & $\begin{array}{c}\text { ELECTRI } \\
\text { MWO }\end{array}$ & MWP & $\begin{array}{l}\text { DIRECT THERMAL } \\
\text { QUAD BTU }(10\end{array}$ \\
\hline 01 & Valles Caldera & 125.00 & 2710 & 2750 & 2700 & 16.6369 \\
\hline 02 & Lightning Dock & 3.30 & 0 & 0 & 0 & 0.2196 \\
\hline 03 & Lwr San Francisco & 3.30 & 0 & 0 & 0 & 0.1600 \\
\hline 04 & Kilbourne Hole & 3.00 & 22 & 50 & 0 & 0.2167 \\
\hline 06 & Jemez Springs & 3.30 & 0 & 0 & 0 & 0.0987 \\
\hline 08 & Radium Springs & 3.30 & 0 & 0 & 0 & 0.1413 \\
\hline 09 & Ojo Caliente & 3.30 & 0 & 0 & 0 & 0.7958 \\
\hline 10 & Gila H.S. below br. & 1.00 & 0 & 0 & 0 & 0.0320 \\
\hline 11 & Gila H.S. $-M F$ & 1.00 & 0 & 0 & 0 & 0.0320 \\
\hline 12 & Montezuma H.S. & 1.00 & 0 & 0 & 0 & 0.0593 \\
\hline 13 & Gila H.S.-Doc C & 1.00 & 0 & 0 & 0 & 0.0320 \\
\hline 14 & Mambys H.S. & 1.00 & 0 & 0 & 0 & 0.0567 \\
\hline 15 & Turkey Creek & 1.00 & 0 & 0 & 0 & 0.0304 \\
\hline 16 & White Sands MR & 3.00 & 21 & 50 & 0 & 0.2089 \\
\hline 17 & Las Alturas & 3.00 & 0 & 0 & 0 & 0.1625 \\
\hline 18 & Berino-Mesquite & 3.00 & 0 & 0 & 0 & 0.7625 \\
\hline 20 & Ponce de Leon & 1.00 & 0 & 0 & 0 & 0.0464 \\
\hline 24 & $\mathrm{~T}$ or $\mathrm{C}$ & 1.00 & 0 & 0 & 0 & 0.0438 \\
\hline 25 & Gila H.S. UMF & 1.00 & 0 & 0 & 0 & 0.0320 \\
\hline 26 & Black Mtn, W Mesa & 1.00 & 0 & 0 & 0 & 0.0413 \\
\hline 27 & Closson & 3.00 & 21 & 50 & 0 & 0.2089 \\
\hline 28 & Playas Valley & 3.00 & 0 & 0 & 0 & 0.1996 \\
\hline 30 & Derry Warm Spring & 3.00 & 0 & 0 & 0 & 0.7315 \\
\hline 33 & Crown Point & 3.00 & 21 & 50 & 0 & 0.2089 \\
\hline 34 & Prewitt NE & 3.00 & 21 & 50 & 0 & 0.2089 \\
\hline 35 & Guadalupe Spring & 7.00 & 0 & 0 & 0 & 0.0542 \\
\hline 36 & Hot Well & 1.00 & 0 & 0 & 0 & 0.0438 \\
\hline 37 & San Ysidro & 1.00 & 0 & 0 & 0 & 0.0438 \\
\hline 44 & Aleman & 1.00 & 0 & 0 & 0 & 0.0490 \\
\hline 51 & Guadalupe Area & 1.00 & 9 & 50 & 0 & 0.0800 \\
\hline 52 & Columbus Area & 3.00 & 22 & 50 & 0 & 0.2167 \\
\hline 53 & San Diego Mtn & 1.00 & 0 & 0 & 0 & 0.0567 \\
\hline 54 & Tularosa Basin $S$ & 3.00 & 21 & 50 & 0 & 0.2089 \\
\hline 55 & Socorro & 3.00 & 21 & 50 & 0 & 0.2089 \\
\hline 56 & Jemez Reservoir & 3.00 & 21 & 50 & 0 & 0.2089 \\
\hline 57 & Lordsburg & 3.00 & 21 & 50 & 0 & 0.2089 \\
\hline 58 & Fort Wingate & 1.00 & 0 & 0 & 0 & 0.0237 \\
\hline 63 & Mancisco Mesa & 3.00 & 0 & 0 & 0 & 0.0882 \\
\hline 64 & Jicarilla Apache & 3.00 & 0 & 0 & 0 & 0.1285 \\
\hline 65 & Little Blue Mesa & 3.00 & 0 & 0 & 0 & 0.1285 \\
\hline & & & & & TOT & 21.3157 \\
\hline
\end{tabular}


data (Na-K-Ca) is as high as $200^{\circ} \mathrm{C}$ (Marlin et al., 1978). The land within the KGRA is mostly federally owned.

The geothermal resource of Jemez Springs is liquid-dominated with numerous surface springs in the canyon (Starkey, pers. obs., 1978). The estimated subsurface fluid temperature is $135^{\circ} \mathrm{C}$ (Marlin et al., 1978). An 800 -foot test well produced $65^{\circ} \mathrm{C}$ water at approximately 80 feet and $50^{\circ} \mathrm{C}$ water at approximately 500 feet (Starkey, 1979). Soda Dam, a natural hot spring, is located one mile north of the village. The land in this area is predominately held by the Village of Jemez Springs and private owners.

The resource of Radium Springs is liquid-dominated, with an external expression of hot springs. The estimated subsurface temperatures are $130^{\circ}-198^{\circ} \mathrm{C}$ (Marlin et al., 1978). Land ownership is predominately federal and state with some private lands.

The geothernal resource at ojo Caliente is liquid-dominated with five hot springs being used to supply a resort spa. The subsurface fluid temperature is estimated at $122^{\circ} \mathrm{C}$ to $161^{\circ} \mathrm{C}$ (Marlin et al., 1978). The land is privately and commercially held.

The Los Alturas geothermal resource is liquid-dominated (Chaturvedi, 1979). Two test wells of 1200 and 1000 feet have been established by the New Mexico Energy Institute at New Mexico State University through the Department of Energy Low Temperature Reservoir Assessment Program to confirm this resource. Water-bearing strata have been located at 265-450 and 750-850 Feet (wel1 $\|_{1} 1$ ) and at 265-420 and 720-850 feet (wel1 \#2). Primary geologic formations can be described as sand and gravel over rhyolitic rock, a lens of sand and gravel (at approximately 720-750 feet), and rhyolitic rock (to a depth of $1200 \mathrm{feet}$ maximum). The bottom hole temperatures of both wells was approximately $63^{\circ} \mathrm{C}$. Two production wells in this resource area show similar. temperatures.

Little is known about the Ponce de Leon resource area. It has been reported (Solar America, Inc., 1978) that the spring discharges 345,000 gallons per day of thermal waters. It is a water-dominated system.

Faywood Hot Springs resource area is also a water-dominated system. The spring discharges approximate 50,400 gallons per day (S.W.N.M. Services to Handjcapped Children and Adults, Inc., 1978).

The geothermal resource at Truth or Consequences ( $T$ or $C$ ) is water-dominated. There are 74 wells and springs in the area with 40 containing water of $25^{\circ} \mathrm{C}$ or higher (City of Truth or Consequences, 1978). Wells are frequently artesian with heads of zero to 58 feet. The Truth or Consequences thermal basin discharge was 2, 260 gallons per day with a heat content of $700,000 \mathrm{BTU} / \mathrm{min}$ (Theis et al., 1941). Land is owned primarily by private owners in town, while portions of town borders are held by the Bureau of Land Management. 
The San Ysidro resource area is a water-dominated geothermal system as evidenced by the hot wells and the hot and warm springs in the vicinity. The subsurface fluid temperature of this resource is estimated at $80^{\circ} \mathrm{C}$ (Marlin et al., 1978). Land is held predominately by $\mathrm{Zia}$ and Jemez Pueblo Indian tribes with a small portion held by the federal government.

The geothermal resource at Socorro is thought to be water-dominated, although no research-oriented deep drilling has occurred within the KGRA. Springs do discharge warm waters along the north-trending fault which separates Socorro Peak from the Rio Grande Valley (Marlin et a1., 1978). The subsurface fluid temperature is estimated at $72^{\circ} \mathrm{C}$. Land is owned primarily by the state, the federal government, and private individuals.

Table 3 summarizes the characteristics of these resource areas. Data on other resource areas are predominately estimates based on surface geothermal exploration methods and work performed under the New Mexico Research and Development Program and the Department of Energy Low Temperature Assessment Program administered by the New Mexico Energy Institute at New Mexico State University.

With the possible exceptions of the vapor-dominated geothermal system confirmed in Baca 非 1 and the suspected vapor-dominated geothermal system at Lightning Dock, the majority of New Mexico's potential geothermal systems are water-dominated. Temperatures of reservoirs separate those suitable for electric generation (greater than $150^{\circ} \mathrm{C}$ ) from those more suited to direct heat technology (less than $150^{\circ} \mathrm{C}$ ). (NOTE: Those resources which have temperatures sufficient to generate electricity can also be developed for direct heat applications).

The hot, dry rock resource area at the LASL Fenton Hill. Site includes 3600 acres of the Baca KGRA. The temperatures of the current rock "reservoir" are in the range of $250^{\circ} \mathrm{C}$ at the depth of the phase I reservoir at greater than 1000 feet (Kaufman and Siciliano, 1979). Precambrian rocks of granite and gneiss are overlain by Pennsylvanian and Permian limestones, sandstones and shales. Cenozoic volcanic rocks form the upper surface of the Jemez Plateau. The test site land is a part of the Santa Fe National Forest. A $10 \mathrm{MW}$ circulating test facility has been operated on the site.

In addition to the geothermal sites listed in the Regional Operations Research Program data base, various other New Mexico areas may be proven to be additional geothermal resource sites with further research. These are best illustrated in Figures 3,4 , and 5 , as indicated by silica and sodium-potassium-calcium geothermometer estimates of subsurface temperatures and total dissolved solids throughout the state (Swanberg, 1979a). Although some areas with temperature estimates of $50^{\circ} \mathrm{C}$ or more appear in Colfax, Union, San Miguel, Quay, DeBaca and Chaves Counties, the only indicated concentration of these data points in the eastern part of the state appear in Harding County in the northeast and in Eddy and Lea Counties in the southeast. 
Table 3. A brief summary of hydrothermal resource data (Marlin et a1., 1978; Baca EIS, 1979; Chaturvedi, 1979).

\begin{tabular}{|c|c|c|c|c|c|}
\hline SITE & SITE NAME & $\begin{array}{l}\text { SURFACE } \\
\text { FLUID } \\
\text { TEMP }\left({ }^{\circ} \mathrm{C}\right) \\
\end{array}$ & $\begin{array}{l}\text { TOTAL } \\
\text { DISSOLVED } \\
\text { SOLIDS (ppm) } \\
\end{array}$ & $\begin{array}{l}\text { RESERVOIR } \\
\text { DEPTH FROM } \\
\text { SURFACE }(\mathrm{ft}) \\
\end{array}$ & OVERLYING ROCK \\
\hline 01 & Valles Caldera & 31 & $3170-7860$ & $6000-9000$ & Tuff, Rhyolite \\
\hline 02 & Lightning Dock & 99 & 1120 & 88 & $\begin{array}{l}\text { Alluvium over } \\
\text { Tertiary } \\
\text { volcanics }\end{array}$ \\
\hline 04 & Kilbourne Hole & $45-83$ & 4900 & - & Volcanic \\
\hline 06 & Jemez Springs & 73 & 2100 & - & $\begin{array}{l}\text { Alluvium over } \\
\text { Permian sands } \\
\text { and shales }\end{array}$ \\
\hline 08 & Radium Springs & $30-85$ & 3700 & - & Rhyolite \\
\hline 09 & Ojo Caliente & 45 & & 87 & $\begin{array}{l}\text { Fractured Meta } \\
\text { Rhyolite with } \\
\text { Pegmetite dike }\end{array}$ \\
\hline 17 & Las Alturas & 46 & 1093 & 265 & $\begin{array}{l}\text { Sand and grave } \\
\text { over Rhyolite } \\
\text { fragments }\end{array}$ \\
\hline
\end{tabular}

20 Ponce de Leon 35

486

23 Faywood Hot Springs

24 Truth or

$36-46$

2500

Consequences

$37 \quad$ San Ysidro

50

$10,000-$

12,000

34

100

Alluvium over
Magdalena
limestone

Sandstone and Shale

Volcanic brecc 


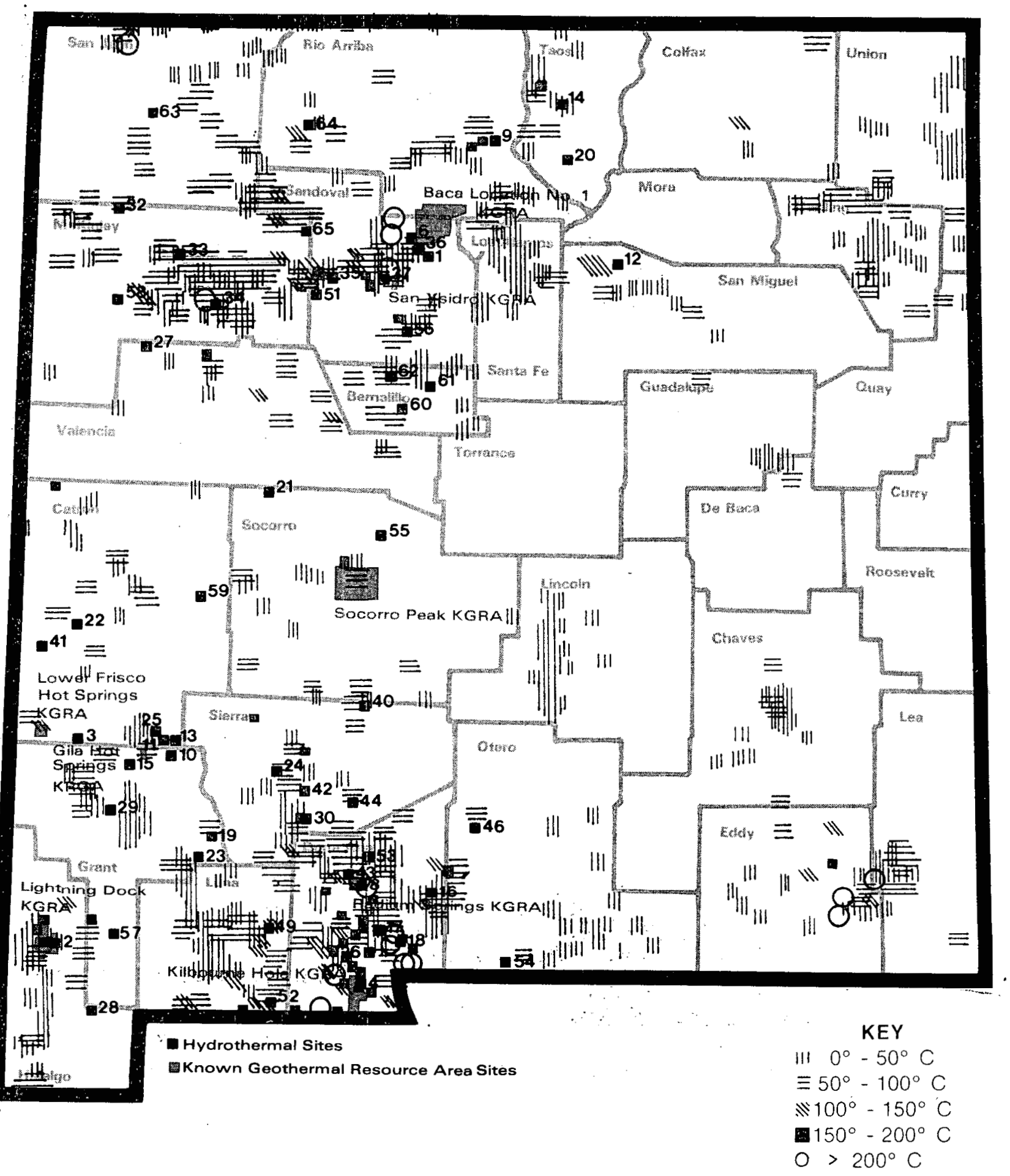

Figure 3. Subsurface temperatures estimated by the silica geothermometer in relation to geothermal sites in New Mexico (Swanberg, 1979a). 


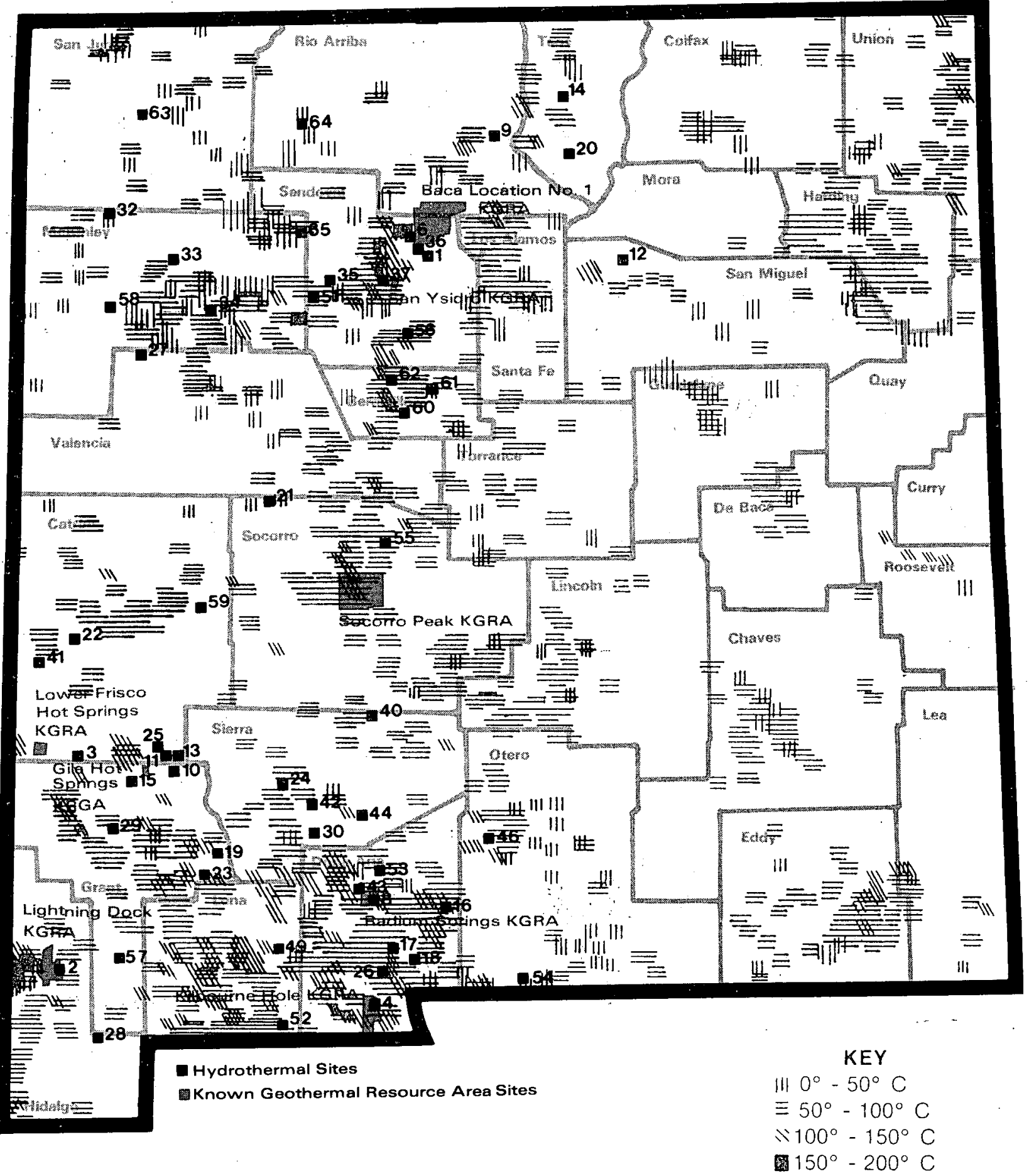

Figure 4. Subsurface temperatures estimated by the sodium-potassiumcalcium geothermometer in relation to geothermal sites in New Mexico (Swanberg, 1979a). 


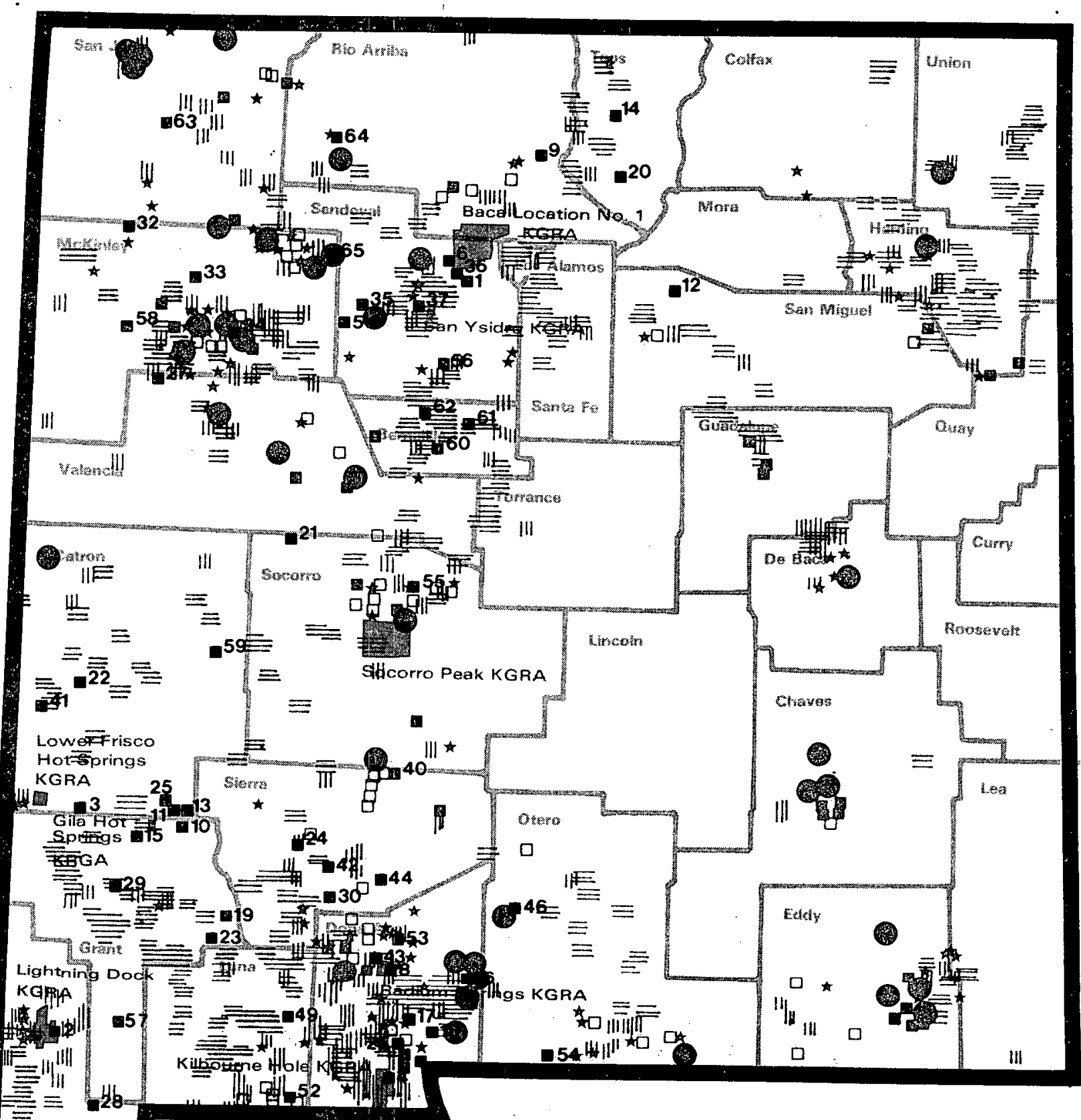

Hydrothermal Sites

住idatyo=

Known Geothermal Resource Area Sites

KEY

- > $4000 \mathrm{mg} / \mathrm{L}$

- $3000-4000 \mathrm{mg} / \mathrm{L}$

D $2000-3000 \mathrm{mg} / \mathrm{L}$

$1000-2000 \mathrm{mg} / \mathrm{L}$

$\equiv 500-1000 \mathrm{mg} / \mathrm{L}$

III $0-500 \mathrm{mg} / \mathrm{L}$

Figure 5. Total dissolved solids (TDS) in relation to geothermal sites in New Mexico (Swanberg, 1979a). 


\subsection{Potential Commercial Development of Geothermal Sites}

With the exception of the Baca 50 MW electrical generation facility, the electrical generation facility planned for Los Alamos Scientific Laboratories at the Fenton Lake hot, dry rock resource area the six direct heat geothermal applications being executed through the state of New Mexico geothermal demonstration program and the NMSU demonstration facility, it is difficult to determine the order in which the 56 hydrothermal sites (or any new sites which may be located in the future) might be developed into commercial applications. Further, it is also difficult to determine at this time the exact nature of the technology to be applied in commercial geothermal applications on each site. Since most of the state's geothermal resource areas are thought to be water-dominated, vapor-dominated technologies can receive little consideration in this project.

Precommercial development activities, in the form of industrial leasing of state and federal lands, are occurring in the following potential geothermal sites (Marlin et al., 1978) and initial sitespecific research activities (Starkey, pers. comm., 1979):

01 Valles Caldera:

02 Lightning Dock:

04 Kilbourne Hole:

06 Jemez Springs:

08 Radium Springs:

09 Ojo Caliente:

16 White Sands Missile Range:

17 Los A1turas:

18 Berino-Mesquite:

24 Truth or Consequences

52 Columbus:
Federal leases to Amax, Phillips and Aminoil; private leases to Union oil of New Mexico;

Federal and state leases to Aminoil, Chevron, Phillips and Amax;

Federal and state leases to Anadarko, Phillips and Hunt Energy Corporation;

Federal leases to Calvert Geothermal Resources and Sun 0i1;

Federal leases to Chevron, Texaco and Aminoil;

State lease to A. J. Antweil;

Initial university (NMSU) research activities;

State lease to Monument Solar Corporation;

Initial university (NMSU) research activities;

Initial university (NMSU/UNM) research activities;

Initial university (NMSU) research activities; 
53 San Diego Mountain: Initial university (NMSU) research activities;

54 Tularosa Basin

Initial university (NMSU) research South: activities;

55 Socorro:

Federal and state leases to Sunoco, Aminoil, Gulf, Chevron, Hoover Wright, John Kel1y, T. W. Cove11o and Deuterium Geothermal Company; initial university (NMIMT) research activities;

61 Albuquerque:

Initial university (UNM) research activities.

Various types of small-scale direct heat commercial development activities are taking place in New Mexico's geothermal resource areas as follows (Marlin et al., 1978 and Starkey, pers. obs., 1979):

02 Lightning Dock:

Space heating of two ranches, several small and one commercial greenhouses; feasibility study for agribusiness and a research wel1;

06 Jemez Springs:

A public bathhouse, one small greenhouse, swimming pool and Soda Dam, a public recreation area; a research wel1;

08 Radium Springs:

Space heating and bathing at a local hotel;

09 Ojo Caliente:

A resort spa;

17 Los Alturas:

Two research exploratory wells and thermal gradient wells and a deep (1000') research well;

24 T or C:

Several bathhouses, two theraputic swimming pools at Carrie Tingley Hospital, space heating of mobile homes and motels;

37 San Ysidro:

Natura1 springs used for bathing;

61 Albuquerque:

Space heating of a commercial building; thermal gradient we1ls.

Geothermal demonstration projects, both federal and state funded, are being established in the following resource areas: 
01 Valles Caldera:

\section{Los Alturas:}

20 Ponce de Leon:

23 Faywood Springs:

24 T or $C:$
A $50 \mathrm{MW}$ electrical power plant, a DOE-funded demonstration by Union 0i1 of New Mexico and Public Service Company of New Mexico; a DOE-funded hot, dry rock electrical power plant to supply power to Los Alamos Scientific Laboratories;

State-funded geothermal space heating for New Mexico State University Center; state and DOE-funded potential process heat extraction of L'eggs plant south of Las Cruces; state and DOE-funded production well for heating of NMSU campus;

Btate-funded solar-geothermal commercial greenhouse;

State-funded commercial greenhouse for a non-profit group;

State and federal funded space heating for city-owned senior citizen recreation building; state-funded space heating for Carrie Tingley Hospital.

Table 4 provides a summary of current commercial activity in New Mexico's resource areas. In addition to existing commercial activities, including domestic water and space heating demonstration at New Mexico State University, potential space heating may be established at two other universities, New Mexico Institute of Mining and Technology and the University of New Mexico, in the near future.

The geothermal resource areas thought to contain high ènough temperatures for electrical generation are, in addition to the Baca, Lightning Dock (02), Kilbourne Hole (04), White Sands Missile Range (16), Closson (27), Crown Point (33), Prewitt NE (34), Columbus Area (52), Tularosa Basin South (54), Socorro (55), Jemez Reservoir (56), and Lordsburg (57). Proximity of these sites to cities with significant populations and/or to major utility companies with sufficient capital to develop a geothermal electrical generation facility might allow reasonable "guesses" as to the order in which these sites might be developed with established electrical generation technology. Thus, in addition to electrical generation commercial development at the Baca, such activity might be reasonably projected for Lightning Dock, Kilbourne Hole and, perhaps, Radium Springs. This activity could be expected to increase rapidly if the nuclear power plant facilities planned for Palo Verde, Arizona, encounter difficulties prior to operation. E1 Paso Electric Company, a major supplier of electricity in southern New Mexico, is a partner in the Palo Verde plant. Other resource areas could receive additional incentives in the short term for electrical generation of geothermal energy. White Sands, for instance, has received a federal alternate energy mandate. 
Table 4. A summary of commercial activity in New Mexico high and low temperature geothermal resource areas.

\begin{tabular}{cl} 
SITE & \multicolumn{1}{c}{ SITE NAME } \\
01 & $\quad$ Valles Caldera \\
02 & Lightning Dock \\
04 & Kilbourne Hole \\
06 & Jemez Springs \\
08 & Radium Springs \\
09 & Ojo Caliente \\
12 & Montezuma H.S. \\
13 & Gila H.S. \\
14 & Mamby's H.S. \\
17 & Las Alturas \\
19 & Mimbres H.S. \\
20 & Ponce de Leon \\
22 & Upper San Francisco H.S. \\
23 & Faywood Springs \\
24 & Tor C \\
37 & San Ysidro \\
55 & Socorro \\
61 & Albuquerque
\end{tabular}

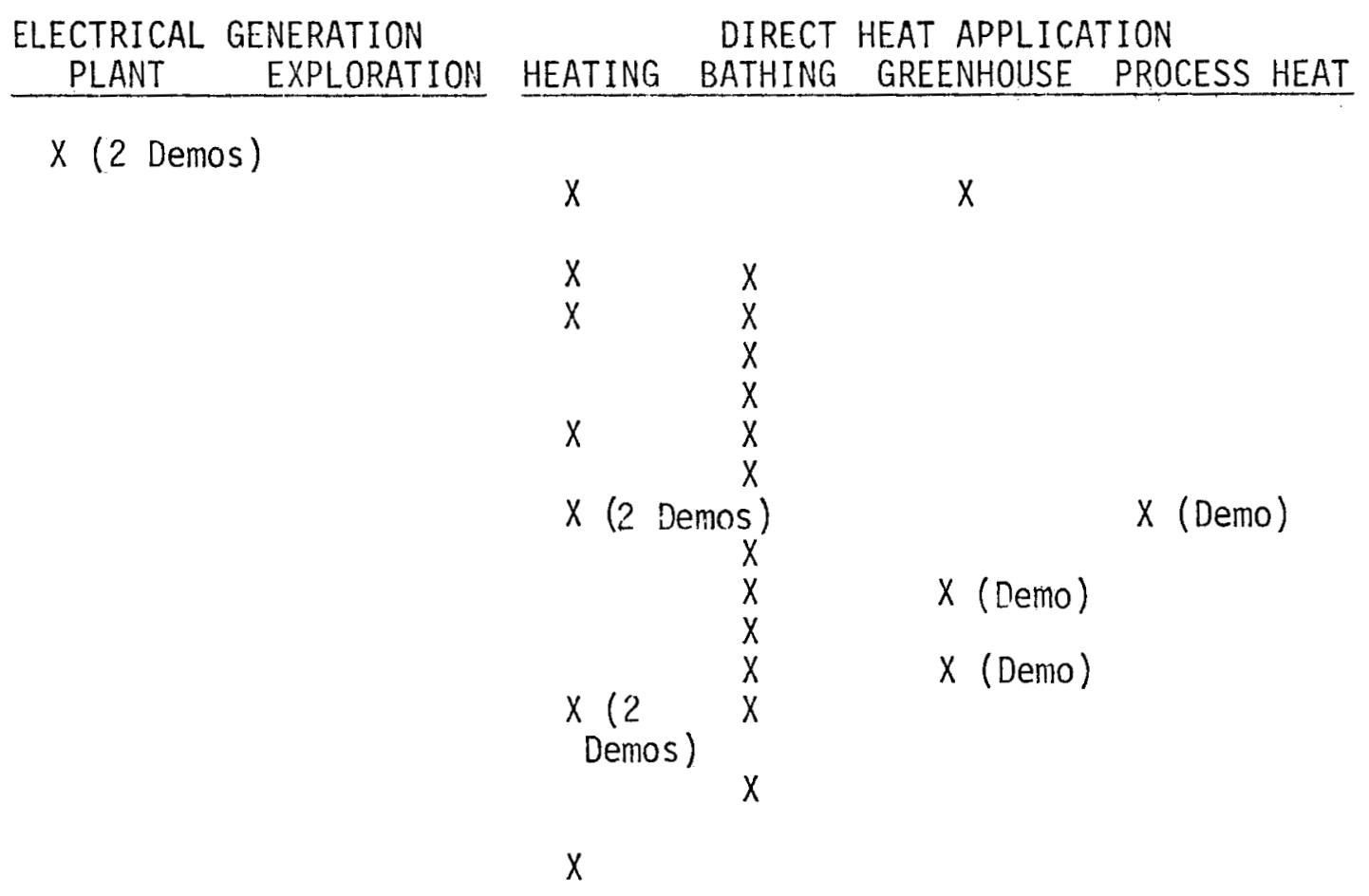


It should be remembered, however, that high temperature reservoirs can also be tapped for direct heat applications and the commercial development of such sites for this purpose could accelerate the use of these sites.

The Regional Operations Research Project for the Development of Geothermal Energy in the Rocky Mountain Basin and Range Region has provided a listing of cities which might qualify as sites for potential geothermal applications based on the Regional Program Progress Monitor (RPPN), a computer data base maintained at New Mexico State University for the 10-state Rocky Mountain Region. The computer program named MARKET, a linear, programming model, calculates a unique ordering of city-geothermal site pairings for economic analysis. The output of this model consists of a list of geothermal resources, the possible temperature of the resource, the names of cities potentially supportable by the resource, their populations, the distance in miles from the resource, the 30-year average annual heating degree days and lowest ambient temperature, and the estimated yearly residential heating demand for the city (Cunniff et al., 1979).

Because of rapid growth rates of many smaller towns, abnormally high conventional energy costs, and the easy accessibility of a high grade geothermal resource, many small communities are prime prospects for early application of geothermal energy. Numerous smaller towns either possess an industrial plant suitable for geothermal application, or are candidates for new industry. Many towns with present populations of slightly more than 100 people could conceivably demonstrate an economic conversion to geothermal energy by the 2000 .

Table 5 .

MARKET ouput for New. Mexico (as of June 1979) is presented in

As each geothermal resource is tapped for energy and the type of technology for extracting geothermal heat is determined, it will be possible to predict the enviromental impact of these activites with greater accuracy than can be determined in the overview program. Commercial activities utilizing New Mexico's geothermal resources are most likely to increase at a rapid rate as more traditional fuels become scarce and/or more expensive to use. 
Table 5. Market output for geothermal resource areas in New Mexico (Cunniff and Rao, 1979).

\begin{tabular}{|c|c|c|c|c|c|c|c|c|}
\hline SITE ID & SITE NAME & $\begin{array}{l}\text { NEW MEXICO GEOTHERMAL } \\
\text { CITY NAME }\end{array}$ & $\begin{array}{l}\text { MARKET } \\
\text { DIST } \\
(M I)\end{array}$ & $\begin{array}{l}\text { POTENTIAL } \\
\text { POP }\end{array}$ & $\begin{array}{l}\text { TEMP } \\
\left({ }^{\circ} \mathrm{C}\right)\end{array}$ & DEGD & $\begin{array}{l}\mathrm{LT} \\
(\mathrm{OF})\end{array}$ & $\begin{array}{l}\text { HEAT DEMAND } \\
\text { PER YEAR } \\
(\text { BTU } \times 1010) \\
(\text { FOR CITY })\end{array}$ \\
\hline 01 & Valles Caldera & Los Alamos & 12 & 11310 & 273 & 6305 & 19 & 68.457 \\
\hline 01 & Valles Caldera & White Rock & 16 & 3861 & 273 & 5850 & 19 & 21.683 \\
\hline 04 & Kilbourne Hole & Meadow Vista & 17 & 1402 & 155 & 2800 & 29 & 3.769 \\
\hline 06 & Jemez Springs & Jemez Springs & 1 & 500 & 73 & 5330 & 20 & 2.558 \\
\hline 08 & Radium Springs & Radium Springs & 0 & 100 & 98 & 3100 & 26 & .298 \\
\hline 12 & Montezuma H.S. & Las Vegas & 4 & 15900 & 130 & 6000 & 18 & 91.584 \\
\hline 14 & Mamby's H.S. & Questa & 14 & 1125 & 125 & 7400 & 15 & 7.992 \\
\hline 14 & Mamby's H.S. & Taos Pueblo & 9 & 1030 & 125 & 6850 & 17 & 6.773 \\
\hline 16 & White Sands Msl Rge & White Sands & 10 & 4167 & 150 & 3500 & 27 & 14.001 \\
\hline 17 & Las A1turas & La Mesilla & 3 & 1850 & 120 & 3195 & 26 & 5.674 \\
\hline 17 & Las A1turas & Las Cruces & 4 & 41600 & 120 & 3195 & 26 & 127.596 \\
\hline 17 & Las Alturas & Univ Pk Tortugas & 4 & 4165 & 120 & 3195 & 26 & 12.775 \\
\hline 18 & Berino--Mesquite & Anthony & 12 & 1728 & 120 & 2800 & 29 & 4.645 \\
\hline 18 & Berino--Mesquite & Mesquite & 2 & 400 & 120 & 3000 & 26 & 1.152 \\
\hline 18 & Berino--Mesquite & San Miguel & 4 & 350 & 120 & 3000 & 26 & 1.008 \\
\hline 18 & Berino--Mesquite & Vado & 4 & 200 & 120 & 2950 & 26 & .566 \\
\hline 18 & Berino--Mesquite & Berino & 7 & 200 & 120 & 2900 & 26 & .557 \\
\hline 19 & Mimbres H.S. & Bayard & 17 & 2900 & 58 & 4450 & 24 & 12.389 \\
\hline 20 & Ponce de Leon & Taos & 6 & 3050 & 105 & 6800 & 17 & 19.910 \\
\hline 23 & Faywood H.S. & Central & 18 & 1850 & 54 & 4450 & 24 & 7.903 \\
\hline 23 & Faywood H.S. & Hurley & 11 & 1700 & 54 & 4300 & 24 & 7.018 \\
\hline 24 & T or $\mathrm{C}$ & Truth or Conseq. & 13 & 5675 & 100 & 3400 & 26 & 18.523 \\
\hline 24 & $T$ or $C$ & Williamsburg & 14 & 575 & 100 & 3400 & 26 & 1.877 \\
\hline 30 & Derry Warm Spring & Garfield & 3 & 300 & 100 & 3300 & 26 & .950 \\
\hline 34 & Prewitt North East & Grants & 18 & 8300 & 150 & 6100 & 17 & 48.605 \\
\hline 34 & Prewitt North East & -Milan & 17 & 1925 & 150 & 6100 & 17 & 11.273 \\
\hline 36 & Hot Well & Santo Domingo Pueblo & 16 & 1662 & 100 & 5300 & 18 & 8.456 \\
\hline 37 & San Ysidro & Jemez Puebio & 6 & 1197 & 100 & 5400 & 20 & 6.205 \\
\hline 37 & San Ysidro & San Ysidro & 4 & 250 & 100 & 5700 & 19 & 1.368 \\
\hline
\end{tabular}


Table 5. Continued

\section{SITE ID SITE NAME}

$\begin{array}{ll}52 & \text { Columbus Area } \\ 53 & \text { San Diego Mountain } \\ 55 & \text { Socorro } \\ 55 & \text { Socorro } \\ 56 & \text { Jemez Reservoir } \\ 56 & \text { Jemez Reservoir } \\ 56 & \text { Jemez Reservoir } \\ 56 & \text { Jemez Reservoir } \\ 56 & \text { Jemez Reservoir } \\ 56 & \text { Jemez Reservoir } \\ 56 & \text { Jemez Reservoir } \\ 57 & \text { Lordsburg } \\ 58 & \text { Fort Wingate } \\ 62 & \text { Laguna }\end{array}$

NEW MEXICO GEOTHERMAL MARKET POTENTIAL

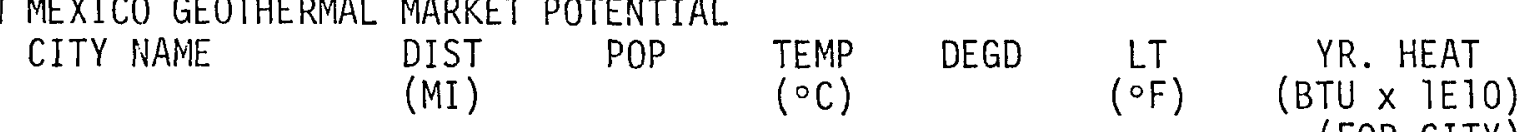

$\begin{array}{lrrrrr}\text { Columbus } & 9 & 260 & 155 & 3250 & 27 \\ \text { Hatch } & 12 & 920 & 125 & 3310 & 26 \\ \text { Socorro } & 19 & 5875 & 150 & 3915 & 24 \\ \text { Bosque Farms } & 15 & 2500 & 150 & 4200 & 21 \\ \text { San Felipe Pueblo } & 14 & 1187 & 150 & 4850 & 18 \\ \text { Albuquerque } & 17 & 286300 & 150 & 4270 & 24 \\ \text { Bernalillo } & 6 & 2775 & 150 & 4725 & 18 \\ \text { Los Ranchos De Albq. } & 14 & 1950 & 150 & 4550 & 19 \\ \text { North Valley } & 17 & 10366 & 150 & 4270 & 24 \\ \text { South Valley } & 17 & 29389 & 150 & 4270 & 24 \\ \text { Sandia Pueblo } & 8 & 6867 & 150 & 4500 & 18 \\ \text { Lordsburg } & 15 & 3900 & 150 & 3950 & 26 \\ \text { Gallup } & 12 & 15300 & 61 & 6400 & 16 \\ \text { Isleta Pueblo } & 19 & 1080 & 50 & 4300 & 20\end{array}$
(FOR CITY) 


\subsection{GEOTHERMAL TECHNOLOGICAL APPLICATIONS AND THEIR ENVIRONMENTAL IMPLICATIONS}

The environmental impacts of geothermal energy development differ with the nature of the geothermal resource and the type of technology involved in utilizing geothermal heat. This section will discuss enviornmental impacts that may be associated with both technological applications associated with using hydrothermal geothermal resources for electrical generation and for direct heating.

\subsection{Applications for Hydrothermal Electrical Generation}

Geothermal electrical generation facilities can probably be developed in only 13 of New Mexico's identified resource areas, unless a large number of binary cycle plants were developed. To better illustrate some of the potential environmental impacts associated with electrical generation facilities, the Baca Environmental Impact Statement draft document (1979) has been used as a case study where appropriate.

\subsubsection{Resource Exploration}

Exploration for geothermal resources can be a "hit or miss" proposition (1ike exploration for oil and gas). At the Baca (01), Union Geothermal of New Mexico found four out of 12 exploratory wells suitable fluid producers for the proposed $50 \mathrm{MW}$ plant (Baca EIS, 1979). Each individual drill site usually requires 194 acre of land for the we 11 pad and two to six acres of land for other equipment, sumps and laydown areas. This impact on the land can be reduced by using existing well pads, where possible, for multiple well drilling. Each site should provide a drainage catchment for drilling fluids to mitigate environmental damage from spilling of fluids. Figure 6 shows a typical equipment layout of a geothermal exploration well (Baca EIS, 1979).

Environmental impacts from exploratory operations (disturbange of vegetation and animal habitat) stem from construction of roads to exploration sites and construction of well pads and well development areas; increased noise and activity from construction traffic on residential areas contiguous to the resource site, perceived incompatibility with natural areas by area residents, accelerated silting of streams (soil and biotic damage), reduced air quality and visibility from fugitive dust, engine emissions and venting of geothermal wells during flow testing, and the venting of gases and dissolved solids during well testing. These impacts are, in general, minor and transient in nature. Mitigation procedures are available to reduce the majority of these impacts during well exploration activites.

The drilling process, however, presents the greatest potential impacts from environmental contamination from loss of drilling muds or $a$ well blowout. These accidental releases of fluids are almost 


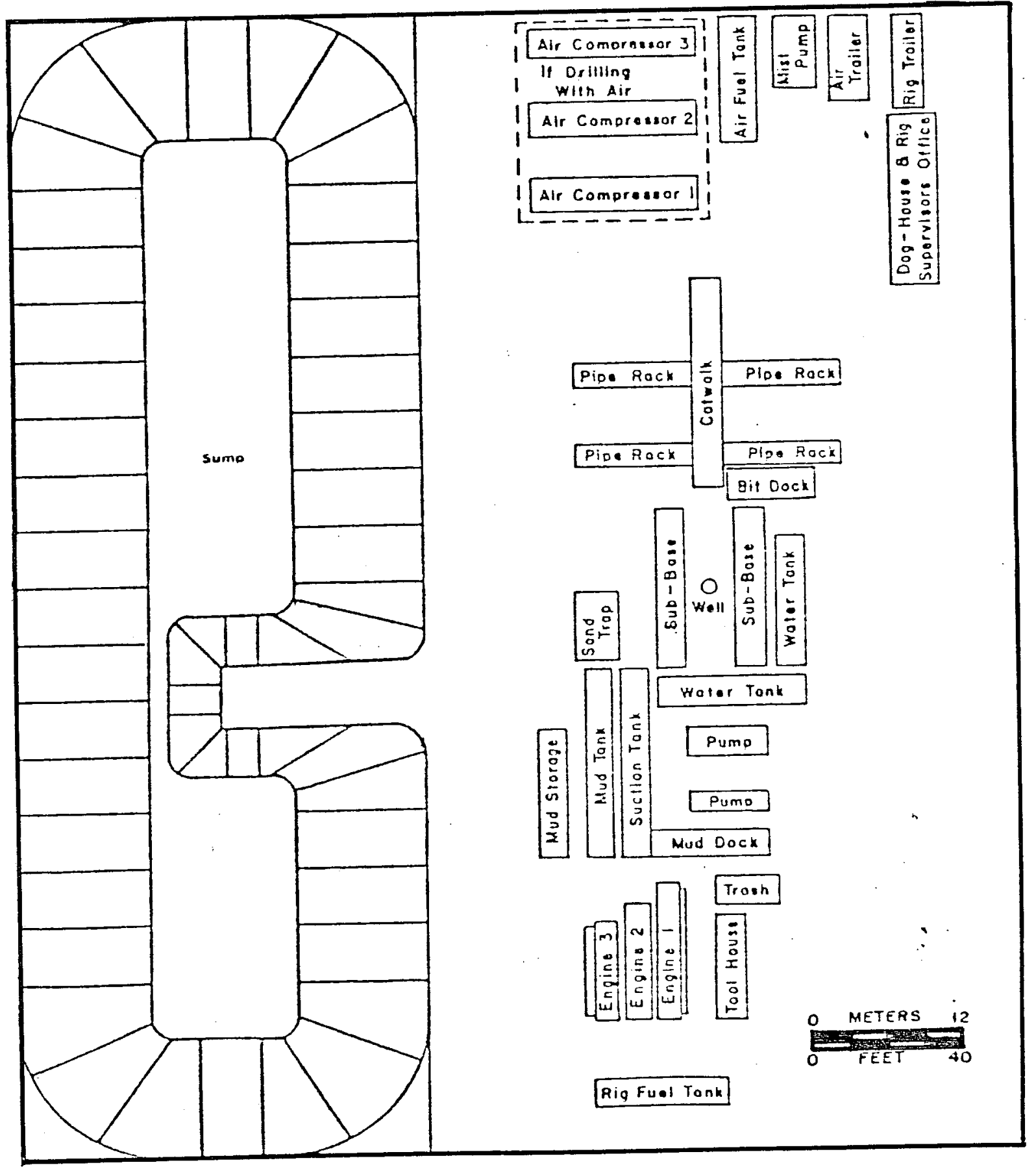

Figure 6. Typical equipment layout at a geothermal exploration well (Baca EIS, 1979). 
totally preventable with today's drilling practices (Hartley, 1978). Drilling muds are comprised of various materials (bentonite, barite, chrome-lignite or chrome lignosulphonate, and sodium hydroxide). Drilling mud disposal, however, is regulated and subject to solid waste regulations. Well blowouts would yield uncontrolled quantities of the field's geothermal fluid to the surface. Surface fluids present a flooding problem, and the impact level depends on the quantity, temperature and chemical quality of the fluid, as well as advance containment measures taken by the developer. Should a blowout occur, repair or closure of well is also regulated within the state. Impact can also occur as a result of geothermal fluid leakage from the well casing or through faulty cement outside the casing into the subsurface. This leakage is difficult to detect.

\subsubsection{We11 Field, Plant and Transmission Line Construction}

Based on Union Geothermal of New Mexico Public Service Company of New Mexico activities to develop the Baca resource area, the following is a "real case" description of some of the parameters involved in developing a geothermal well field, plant and transmission line electrical generation facility (Baca EIS, 1979). It should be noted, however, that variations in this data would possibly occur in future reservoir development in other resource areas.

The total area of a well field at the Baca for a $50 \mathrm{MW}$ plant will be approximately 42 acres per well initially, decreasing to 20 acres per well over a 30-year plant operation. The total area of the project well field will be a maximum of 715 acres, but the actual disturbed area will be about $10-20 \%$ of this area (Baca EIS, 1979). The biota will, of course, be disturbed in the well field. Well drilling can require up to 25,000 liters $(6,300$ gallons $)$ of water per day during muddrilling operations. Drilling water can consist of creek water; well water or geothermal fluid. Diversion of waters from agriculture or other purposes can cause conflict, but water right regulations would probably resolve this conflict prior to drilling. Road construction to drilling sites can have an average disturbed area of two acres per mile. Damage can be mitigated by using existing roads or trails, following natural topography, using good design practices and utilizing a culvert drainage collection system prior to exiting surface runoff into natural drainage systems.

Piping routes to supply geothermal fluid to the plant and to injection plants can require a maximum width of 50 feet initially, but much of that can be allowed to revegetate to a width of 15 feet after initial construction, thus mitigating some of the initial disruption of habitat. The revegetation process creates diverse habitat for plants and animals.

Construction activities of transmission lines consist of clearing and site preparation for the right-of-way, structure sites and access roads; erecting of transmission structures and line stringing, and cleaning and reclamation activites. The amount of clearing and grading necessary for construction of the right-of-way will vary with the 
construction site. For electrical lines, vegetation is usually topped to provide minimum conductor clearance. Danger trees (those which might fall or otherwise contact the lines) are removed from the vicinity of the lines. During construction for electrical lines, a transmission structure site will be cleared for each structure required, each site being approximately $100 \times 150$ feet. In addition, conductor sites of $100 \times 200$ feet will be cleared at approximately three mile intervals along the right-of-way. Environmental problems associated with transmission lines include erosion and related water silting, noise associated with construction equipment, and disruption of plant and animal habitat. Mitigating procedures include various cleanup, revegetation and reclamation activities. Noise and temporary air pollution can be impacts generated by construction activities.

Typical total space requirements for geothermal electrical generation plants including equipment areas, maintenance shops and service areas can be approximately 20 acres per plant. Construction activities consist of earth moving, concrete pouring, equipment installating, and field fabricating and erecting of major systems that will extend over a period of about four years. If the plant site is remote, major components and construction materials will probably be shipped to the site by truck. The population of laborers at the site will vary during the construction period. The impact of this temporary population fluctation, if labor and materials are imported, will affect nearby communities in a positive manner for the general economy and perhaps a negative manner for housing and community services.

\subsubsection{Plant Operation}

\subsubsection{Direct, Dry Steam (DDS) Conversion Process}

The simplest geothermal resource to exploit for electrical power is the direct, dry steam resource. Power plants at The Geysers (California), Larderello and Monte Amiata (Italy) and Matsukawa, Onikobe and Kakkonda (Japan) operate with direct dry steam. Figure 7: is a schematic flow diagram for such a system. The figure shows a condensing turbine with a mechanically induced cooling tower. The Italian plants use natural draft towers, and some plants use noncondensing, exhausting-to-atmosphere turbines. The steam expansion process (Figure 7) from 1 to 2 takes place irreversibly. The working fluid (dry steam) is admitted to the turbine at 1 , condensed at 3 , and either evaporated from the stack of the cooling tower or reinjected into the reservoir as liquid from the cooling tower cold well overflow. Power plants at The Geysers have utilization efficiencies of $60 \%$ (DiPippo, 1978).

Environmental impacts of this process are related to the evaporation of the working fluid from the cooling tower. Composition of the working fluid will determine the type and degree of impact. Subsidence caused by loss of working fluid to the atmosphere and reservoir drawdown is a potential environmental problem. Drilling of new we1ls in response to reservoir depletion requires one well for each 

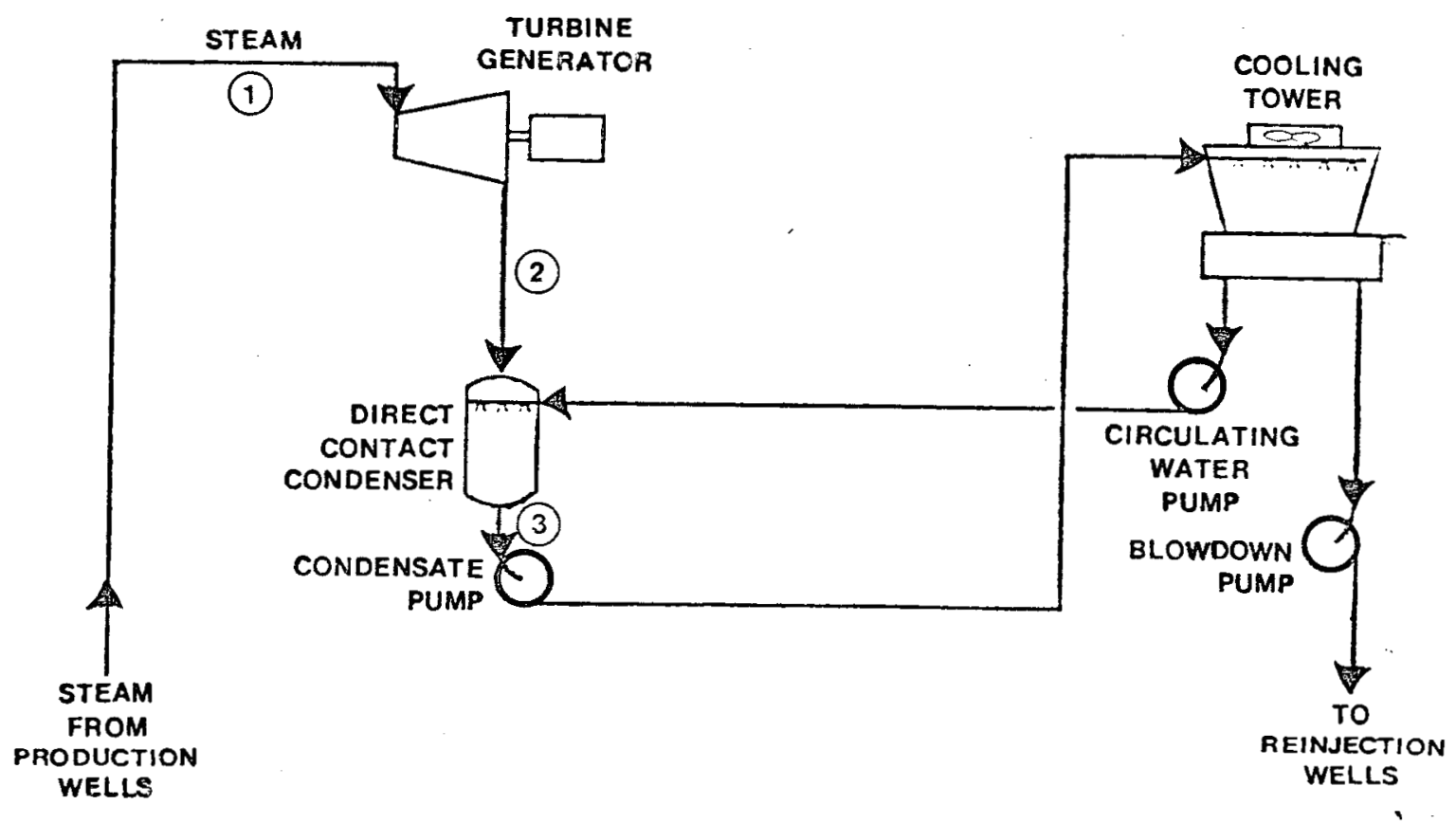

REINJECTION WELLS

Figure 7. A schematic diagram for the direct dry steam (DDS) energy conversion process (DiPippo, 1978). 
initial well over a 30 year period. Noise may be a problem at the turbine and during well venting. Solid waste disposal may also be important. No New Mexico geothermal resource has been identified as having dry steam as its working fluid.

\subsubsection{Separated Steam (SS) Conversion Process}

Some geothermal wells have a wellhead product that consists of a two-phase mixture of liquid and vapor. The quality of the mixture (i.e., the mass fraction of the vapor phase) depends on the reservoir properties and the wellhead pressure. It is not difficult to separate the phases, either at each wellhead, at centrally located stations or at the power house. Plants at Cerro Prieto (Mexico), Ahuachapan (EI Salvador), Otake and Onuma (Japan) and Pauzhetka (Soviet Union) operate as separated steam plants (DiPippo, 1978). Figure 8 is a schematic flow diagram for such a system. For this kind of plant, the fluid in the reservoir must be a compressed liquid at elevated temperature. As the fluid comes to the surface under a reducing pressure, it flashes into steam. The plant equipment is essentially the same as for the Direct, Dry Steam (DDS) system; the difference includes the addition of the separator and a ball float check valve to prevent massive water ingestion by the turbine in the event of a liquid backup in the separator. The utilization efficiency of the Cerro Prieto plant, for example, is about 45\% (DiPippo, 1978).

Environmental impacts of this process would be related to the releasing of fluid from the cooling tower where the composition of the working fluid will determine the type and degree of impact. Some noise problems could occur at the point of steam flashing and well venting. Subsidence and reservoir drawdown and solid waste disposal could be potential environmental problems. This type of process might be used in New Mexico in resource areas which have a compressed fluid at an elevated temperature.

\subsubsection{Single-Flash (SF) Conversion Process}

When the geofluid emerges at the wellhead as a liquid under pressure (a saturated 1iquid), a single-flash steam system (SFS) is utilized. Figure 9 is a simple schematic flow diagram for such a system. The flashing process, instead of occuring in the wellbore, as in the case of the Separated Steam (SS) system, occurs in surface equipment designed to reduce the fluid pressure to some optimum value. Otherwise, the Single-Flash system is quite similar to the Separated Steam (SS) system (DiPippo, 1978).

The power plant designed for use in the Baca Demonstration Plant (Baca EIS, 1979) is an example of this process (Figure 10). The 1iquid geothermal fluid or mixture of stean and liquid is flashed to steam in satellite steam separators connecting several geothermal wells to common steam lines. From the separators the steam is delivered by insulated 


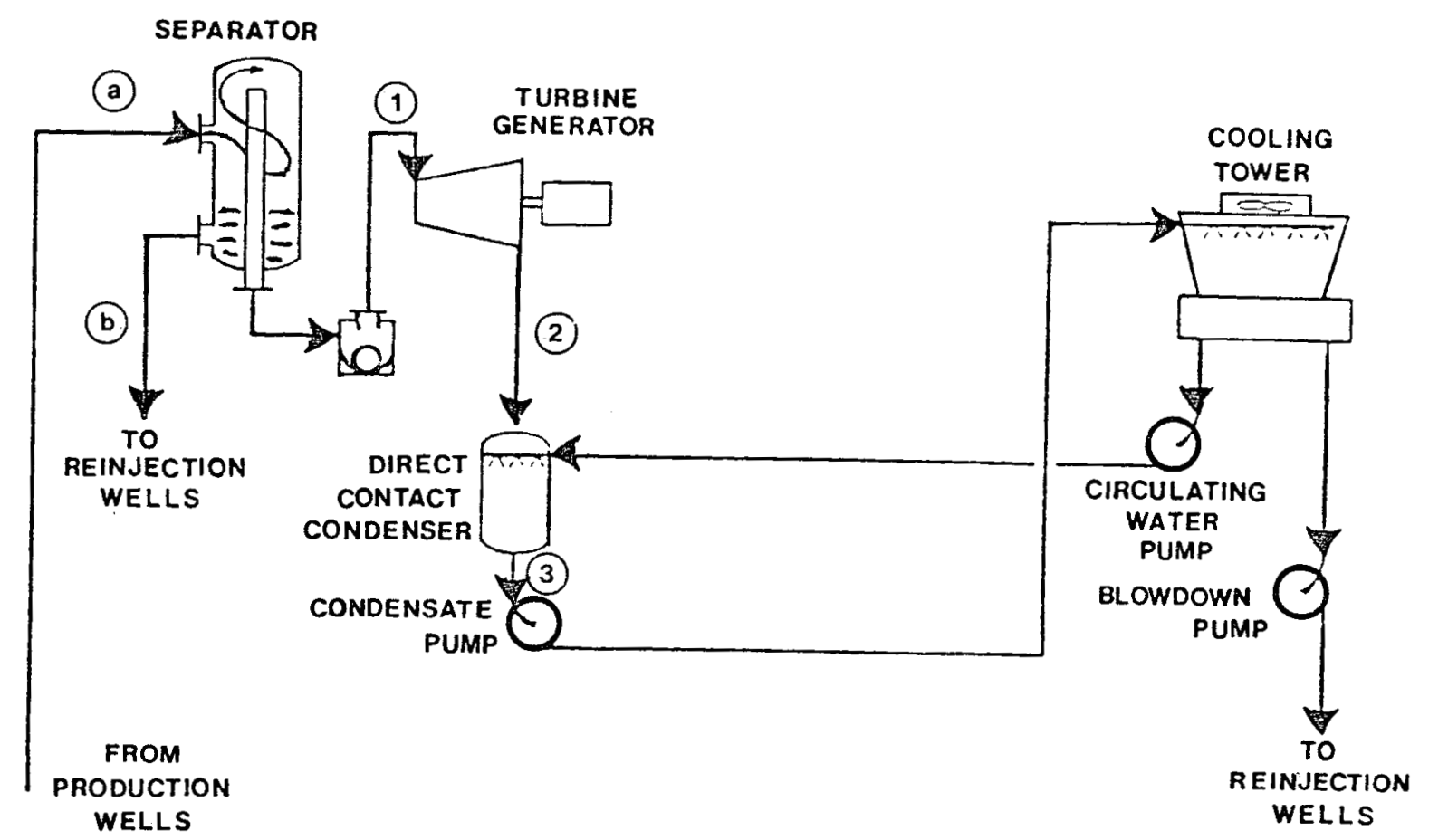

Figure 8. A schematic diagram for the separated steam (SS) energy conversion process (DiPippo, 1978). 


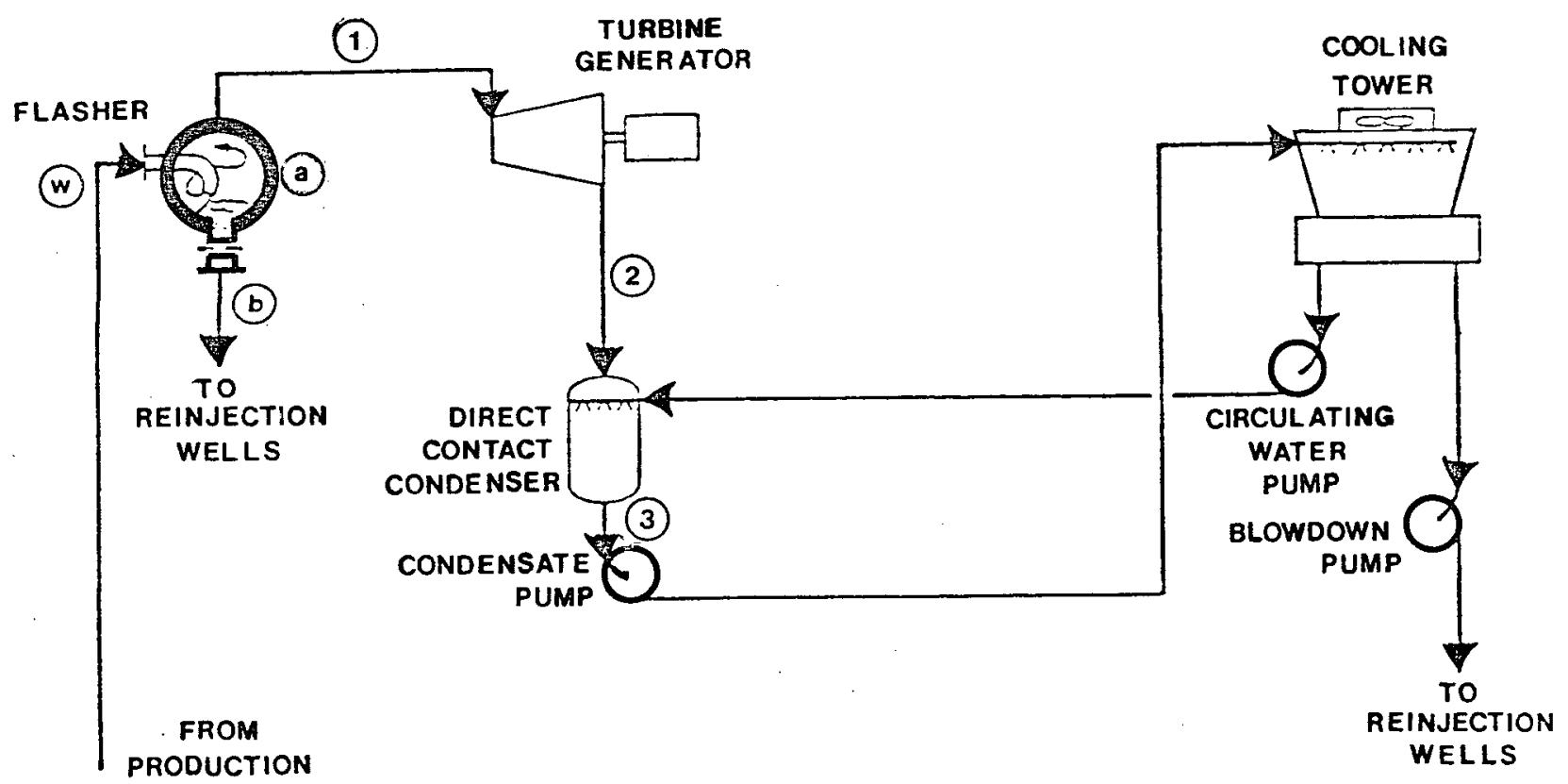

WELLS

Figure 9. A schematic diagram for the single-flash (SF) energy conversion process (DiPippo, 1978). 


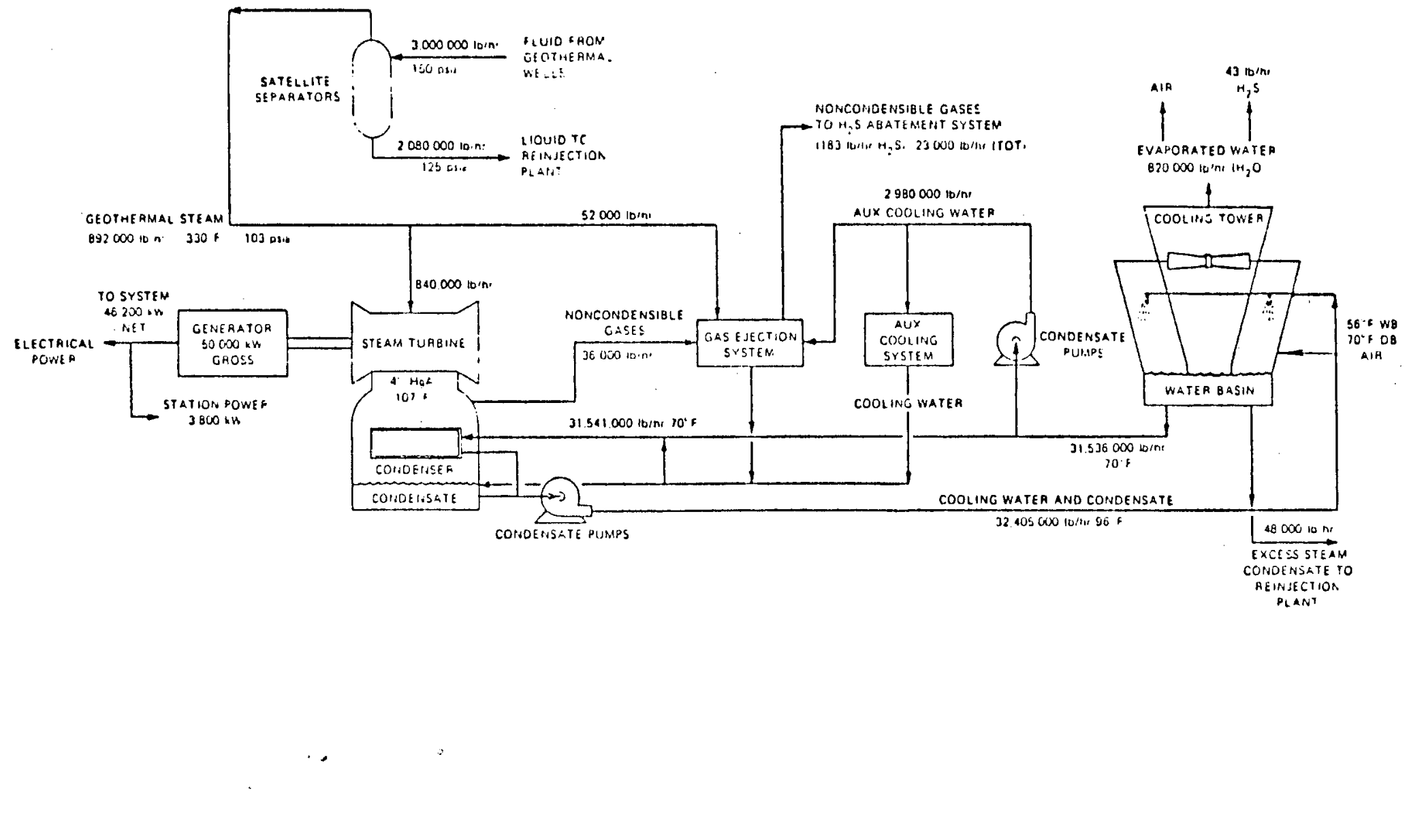


pipe to the turbine inlet at saturation conditions of $710 \mathrm{kPa}$ and $166^{\circ} \mathrm{C}$, and the liquid is sent to the injection plant. Figure 10 shows the approximate flow rates for each subsystem. Geothermal fluid condensate from the turbine is collected and circulated through the cooling tower where it is cooled and recirculated to the turbine condenser as cooling water. This recirculation of the geothermal fluid frees the plant from the requirement of large quantities of fresh water which is common with fossil-fueled and nuclear power plants. The steam condensate and the cooling water are not mixed in the condenser, thereby providing for more thorough extraction of noncondensable gases before the fluid passes through the cooling tower. The extracted gases are circulated to the hydrogen sulfide abatement system, where they are treated by the Stretford process, converting a high percentage of the hydrogen sulfide into elemental sulfur.

Environmental impact may stem from release of hydrogen sulfide into the atmosphere. Since the fluid that circulates through the cooling tower will have a high percentage of the hydrogen sulfide removed by prior treatment, the hydrogen sulfide emissions to the atmosphere will be less than six grams per second, maximum. Other effluents of operation consist of the Stretford Process fluids, cooling tower blowdown and excess geothermal fluids which are sent to the injection station, and the geothermal fluid in the form of water vapor and drift droplets released to the atmosphere. Approximately $0.2 \%$ of the total cooling tower discharge is in the form of drift. The vapor and drift released to the atmosphere will contain dissolved solids and noncondensable gases present in the geothermal steam. Table 6 shows the average expected amounts of the constitutents. Although the gases will be present in the same amount, the drift and liquid to be injected will contain dissolved solids in slightly higher concentrations because of recirculation of cooling water and evaporative losses to the atmosphere. Total dissolved solids in the cooling tower effluents are estimated to be about $400 \mathrm{ppm}$. The release of vapor by the cooling tower is the main consumptive use of water by the plant. Water loss, net withdrawal, within the system of geothermal fluid from the reservoir is $27 \%$. To offset possible reduction in surface water flow in the Jemez River, Union 0il has applied for a permit to withdraw 34-59 acres of irrigated crop land from irrigation by the Jemez River. The proposed $50 \mathrm{MW}$ plant is estimated to retire 14 acres of irrigated land over the 30 year life of the plant (Baca EIS, 1979). Noise may be a problem during wellhead venting.

\subsubsection{Separated-Steam/Single-F1ash (SSSF) Conversion Process}

These plants operate with a two-phase geofluid at the wellhead. Two flashes occur, one below the surface (typically in the wellbore) and one above the surface in a specially-designed flash tank. plants of this type are at Hatchobaru (Japan) and Krafla (Iceland). Figure 11 shows a schematic diagram of such a system (DiPippo, 1978). The essential difference between this and a single-stage system is that a dual-pressure turbine is typically employed in the former system. Two individual turbines arranged in a tandem-compound fashion may be 
Table 6. Average chemical analysis of geothermal steam (without scrubbing) for the $50 \mathrm{MW}_{\mathrm{e}}$ Baca Power Plant (Baca EIS, 1979).

$$
\mathrm{pH}, 4.5
$$

\begin{tabular}{lc}
\hline \multicolumn{1}{c}{ Constituent } & Concentration (mg/liter) \\
\hline & Solids \\
Suspended solids & 7 \\
$\mathrm{SiO}_{2}$ & 35 \\
$\mathrm{HCO}_{3}$ & 5 \\
$\mathrm{SO}_{4}$ & 2 \\
$\mathrm{Cl}$ & 21 \\
$\mathrm{Ka}$ & 8 \\
$\mathrm{Ka}, \mathrm{Mg}, \mathrm{Ba}, \mathrm{B}, \mathrm{F}$ & 3 \\
& 1.0 \\
\hline \multirow{2}{*}{ Constitutent } & Concentration (ppm) \\
\hline
\end{tabular}

Noncondensable gases

$\begin{array}{lrr}\mathrm{CO}_{2} & 28,250 & 12,000 \\ \mathrm{H}_{2} \mathrm{~S} & 204 & 125 \\ \mathrm{~N}_{2} & 56 & 37 \\ \mathrm{H}_{2} & 2 & 14 \\ \mathrm{CH}_{4} & 2 & 2\end{array}$

$a_{\text {Weighted average of noncondensable gases, } 2.64 \%}$ of steam. 


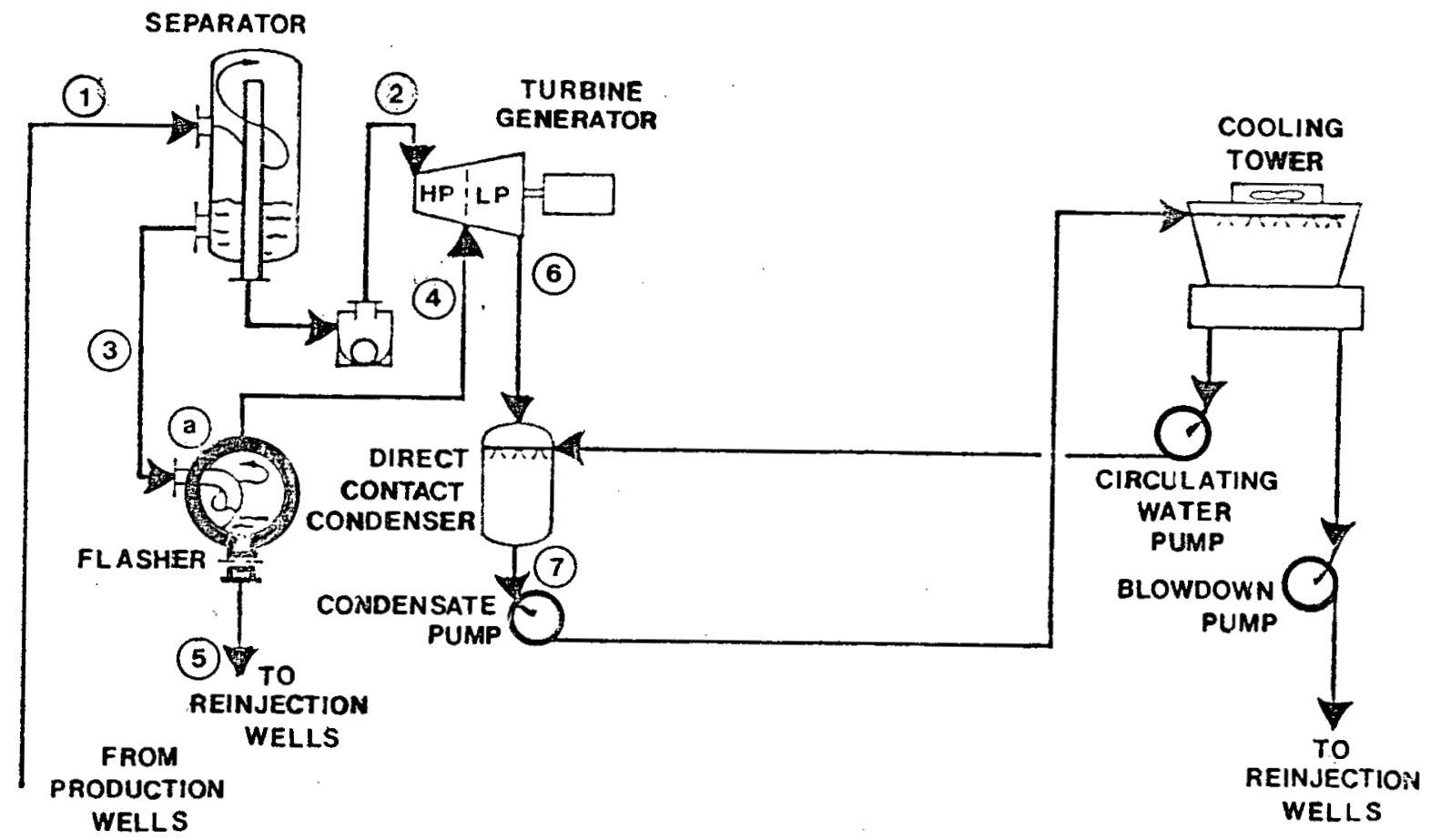

Figure 11. A schematic diagram for the separated-steam/single-flash (SSSF) conversion process (DiPippo, 1978). 
used. The high-pressure steam from the separator flows through the high-pressure portion of the turbine entering at 1 . The flasher produces additional steam from the liquid fraction of the separation process by an additional pressure drop. This steam is mixed with the steam from the high-pressure turbine at the pass-in section of the turbine. Figure 11 illustrates the tandem-compound turbine arrangement wherein two separate cylinders are used for the high- and low-pressure sections, both exhausting to a common condenser.

Environmental impacts of this process would be related to the releasing of fluid from the cooling tower where the composition of the working fluids will determine the type and degree of impact related to and the use of makeup water at the cooling tower. Noise problems can occur at the point of steam flashing and wellhead venting. Subsidence and reservoir drawdown could be potential environmental problems.

\subsubsection{Binary Cycle Conversion Processes}

These systems are usually called binary cycles because a secondary working fluid (a fluorocarbon or hydrocarbon) is used in a main Rankine cycle with the geofluid providing the required thermal energy to vaporize and superheat the secondary working fluid. Two small plants operating on this system are located at Paratun'ka (Soviet Union) and Otake (Japan). Figure 12 is a schematic diagram of such a system (DiPippo, 1978). The advantages of a binary cycle over a flash steam system include greater suitability to low temperature hydrothermal resources, smaller and less expensive turbines, high-pressure operation eliminating vacuum operating problems, non-corrosive working fluid in the turbine, higher turbine efficiencies, reduced stress and vibration problems with turbine blades, lower condensing temperatures, less damage to boiler feed pumps, and completely dry expansion. Disadvantages of a binary cycle include cost of secondary working fluids, leakage that may cause system damage, cost of heat exchangers, quantity of brine needed (disposal problems), and flammability of hydrocarbon working fluids (DiPippo, 1978).

Environmental impact issues center around the discharge of hydrocarbons from cooling tower, the amount of make-up water needed, disposal of spent geothermal brine deposits on the heat exchanger, and fire danger from flammability of hydrocarbons. New Mexico's many low temperature geothermal resource areas could utilize these systems to produce electricity in small communities.

\subsection{Applications for Direct Heat Use}

Direct heat applications of geothermal energy in New Mexico could be developed in all of the 56 hydrothermal sites. As geothermal energy for heating and/or cooling and process heating becomes economically competitive with energy from natural gas, electricity or propane, direct heat applications will become more numerous in New Mexico. 


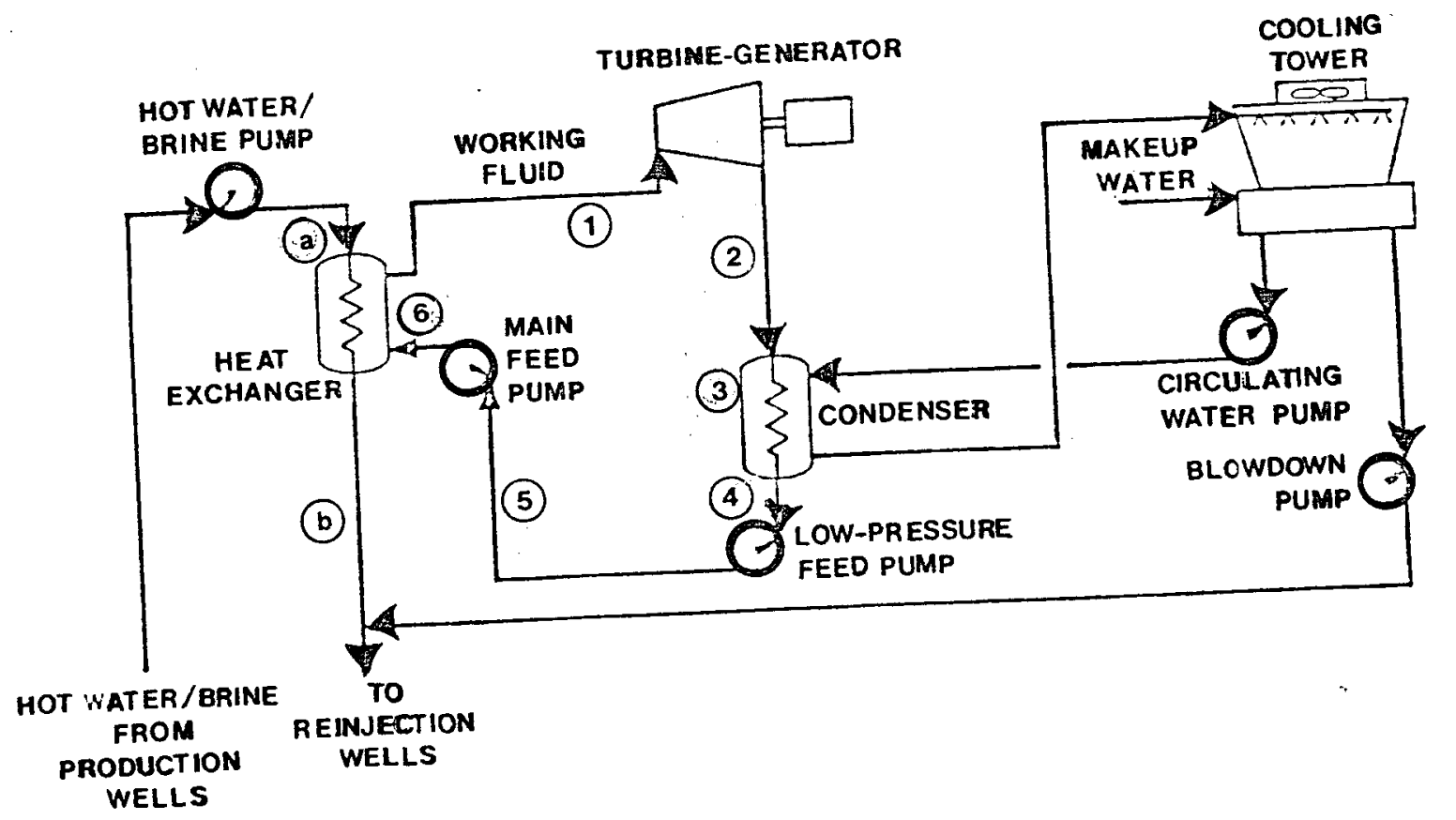

COOLING

TOWER

HOT WATER/

BRINE PUIAP

(a)

Figure 12. A schematic diagram of a binary cycle conversion process (DiPippo, 1978). 


\subsubsection{Resource Exp1oration}

Exploration for geothermal resources for direct heat use are as speculative as for electrical generation. Because shallower wells can often be established (due to lower temperature requirements), the percentage of success in bringing "in" a geothermal resource is likely to be higher for direct heat applications than for electrical generation. Further, fewer wells are usually required unless the application is for district heating of large portions of a town or city. Well drilling space requirements may vary to some degree, but a minimum of one to two acres per well will probably be required.

Environmental impacts from exploratory well drilling can be expected to be relatively the same for electrical generation drilling. These are removal of vegetation and animal habitat for construction of roads and we11 pads, acceleration of erosion into streams, noise pollution and reduced air quality from dust and engine emissions and the venting of gases and dissolved solids during well testing. The nature of the financial risk involved in geothermal drilling on a small scale may cause relatively new drilling companies to experience well blowouts, although sufficient technology exists to prevent this or at least reduce its occurrence. Most of these impacts can be mitigated during exploration.

\subsubsection{Building and Heat Delivery System Construction}

After the geothermal production (and reinjection) wells have been established, building construction associated with direct heat applications of geothermal energy are for the most part the same as construction of buildings without geothermal heat. Environmental impacts would only differ if distribution lines of geothermal waters are extended over a long distance (a distance greater than for electrical conduits or natural gas lines). Geothermal distribution lines under sidewalks or roads can help keep these structures free of snow and ice.

\subsubsection{Geotherma1 Systems Operation}

\subsubsection{Direct Use of Geothermal Waters}

Direct use geothermal systems are the most simple in design. They utilize geothermal fluids directly in buildings or in agricultural operations. Fluids are pumped (or flow) directly into swimming pools, health spas and heating pipes. After the geothermal heat is acquired and used, fluids may be discharged on the surface of the ground or reinjected into the geothermal reservoir. Since these systems usually use low temperature geothermal resources, the geothermal fluids are generally less saline, and contain fewer contaminants than other geothermal fluids. Environmental impacts in these operations are minimal and are largely the result of the disposition of geothermal fluids and scale (solid waste) that has built up within the delivery 
systems. New Mexico already has a number of these systems in operation and more can be anticipated as utility costs continue to rise.

\subsubsection{Surface Heat Exchanger}

The surface heat exchanger geothermal system extracts heat from the geothermal fluids by exposing the fluids to a heat exchanger, where the heat is absorbed into another fluid for transmission as a heat source in buildings and other small-scale applications. In this system the geothermal fluids are contained in a closed 1oop, being released to the surface or returned to the resource through reinjection. Environmental issues arise primarily from the handing of spent geothermal fluids. The number of geothermal wells and their daily flow rates, however, may cause reservoir drawdown that can affect those systems in the same resource reservoir that use geothermal water directly. Reinjection of fluids is thought to reduce this impact. Solid waste disposal from the heat exchanger would also be a source of impact.

\subsubsection{Down-the-Hole Heat Exchanger}

The down-the-hole heat exchanger geothermal system is very similar to the surface heat exchanger except that the heat exchanger is installed in the geothermal well and the secondary fluid is transported to the surface for direct heat use. This system has the advantage of not removing the geothermal fluids from the reservoir. Thus, environmental impacts of this system are minimal. Solid waste disposal from the heat exchanger is a source of impact in this system as we11.

\subsubsection{Heat Pump}

This system operates like a giant reversible refrigerator, transfering heat from the ground to a building during the winter, and from the building back into the ground during the summer. A liquid refrigerant (freon) circulates through the heat pump system. As it passes through the heat exchanger coil at the (geothermal) energy source, it absorbs heat energy, becoming a gas. The gaseous refrigerant is pumped into a second heat exchanger (within the building) that extracts heat which is distributed throughout the building via a forced-air heating system. In summer, the system is reversed causing heat from the building to be redistributed to the energy source, thus cooling the building (American Groundwater Consultants, Inc., 1978). Since geothermal fluids are not circulated above ground, environmental impacts of this system are minimal.

3.3 Summary of Existing or Planned Geothermal Technological Applications in New Mexico

Commercial development of geothermal resources, on an extremely small scale, has probably occurred since the earliest influx of humans 
into what later became the state of New Mexico. Hot springs were used (and are still today) for bathing and medicinal purposes prior to the influx of Anglo societies. Even prior to statehood, hot springs were in continuous use for these purposes. In recent years, a variety of other geothermal applications have developed (Table 7).

\subsubsection{Electrical Generation}

The Union Oil/Public Service Company of New Mexico 50 MW single-flash electrical generation facility utilizing a stretford hydrogen-sulfide abatement system, cooling tower and reinjection wells is scheduled to be "on-line" in 1982 (see Section 3.1.3.3 for a detailed description of this system). If this facility in the valles Caldera (Baca \#1 KGRA) encounters no difficulties, additional generation units are planned to expand the facility to $400 \mathrm{ME} \mathrm{e}$.

At present, no other electrical generation facilities are scheduled for construction in New Mexico.

\subsubsection{Direct Heat Applications}

\subsubsection{Space and Water Heating}

Near the Lightning Dock resource area in the Animas Valley, two ranches utilize geothermal waters for space heating. At Radium Springs, the Radium Springs Hotel and resort is geothermally heated. At the Gila Hot Springs geothermal waters are used to space heat a ranch. The Yucca Lodge at Truth or Consequences has a similar heating application. All of these applications utilize the geothermal waters directly, discharging those waters to the surface.

At the Las Alturas resource area, New Mexico State University is currently constructing a geothermally-heated University Center and President's Residence as a demonstration facility. A surface: heat exchanger with a reinjection well is planned for use in this facility. New Mexico State University also plans to heat a major portion of the campus hot water supply utilizing this resource area and a similar system in the near future (two-four years).

The State of New Mexico has funded two geothermal demonstrations in the city of Truth or Consequences to be constructed within 1980. Both of these systems will use surface heat exchangers, with or without injection wells. (It is a common practice in Truth or Consequences to release geothermal waters into the city's waste system or surface waters.) Geothermal or geothermally-assisted heating systems will be constructed at the city-owned Senior Citizen's Center and the state-owned Carrie Tingley Hospital.

The Sandia Savings Building in downtown Albuquerque is operating a geothermal heating and cooling system that utilizes a heat pump. Water is discharged into the geothermal reservoir. 
Table 7. Geothermal technologies planned or in operation within New Mexico geothermal resource areas.

\begin{tabular}{cl} 
SITE & \multicolumn{1}{c}{ SITE NAME } \\
01 & $\begin{array}{l}\text { Valles Caldera } \\
\text { Lightning Dock }\end{array}$ \\
02 & Jemez Springs \\
06 & Radium Springs \\
09 & 0jo Caliente \\
12 & Montezuma H.S. \\
13 & Gila H.S. \\
14 & Mamby's H.S. \\
17 & Las Alturas \\
19 & Mimbres H.S. \\
20 & Ponce de Leon \\
22 & Upper San Francisco H.S. \\
23 & Faywood Springs \\
24 & T or C \\
37 & San Ysidro \\
61 & Albuquerque \\
& \\
SF $=$ & Single Flash System \\
HDR $=$ Hot Dry Rock System \\
DU = Direct Use
\end{tabular}

ELECTRICAL GENERATION

SF

\begin{tabular}{|c|c|}
\hline DU & \\
\hline חI & DU \\
\hline DU & DU \\
\hline & DU \\
\hline DU & DU \\
\hline & DU \\
\hline SHE (2) & \\
\hline & $\begin{array}{l}\text { DU } \\
\text { DU }\end{array}$ \\
\hline & DU \\
\hline & DU \\
\hline DU, $\operatorname{SHE}(2)$ & DU \\
\hline & DU \\
\hline
\end{tabular}

SHE $=$ Surface Heat Exchanger

DHE $=$ Direct Heat Exchanger

$H P=$ Heat Pump
Unknown

SHE
SHE
hanger
changer




\subsubsection{Bath Houses and Bathing}

Geothermal waters are utilized directly in bath houses or natural springs at Jemez Springs, Radium Springs, Ojo Caliente, Montezuma Hot Springs, Gila Hot Springs, Mamby's Hot Spring, Mimbres Hot Spring, Ponce de Leon Hot Spring, Upper San Francisco Hot Spring, Faywood Springs, Truth or Consequences, and San Ysidro. In addition, Carrie Tingley Hospital in Truth or Consequences and the Southwest Services to Handicapped Children and Adults at Faywood Hot Springs use geothermal water to supply swimming pools used for physical therapy with handicapped children and adults.

\subsubsection{Greenhouses}

A large geothernally-heated greenhouse with 100,000 square feet of space is located near the community of Cotton City near the Lightning Dock resource area. The heating system utilizes a surface heat exchanger, and geothermal fluids are discharged to the surface waters.

In Jemez Springs, a Buddhist colony operates a small greenhouse that uses geothermal waters directly and releases the water to the nearby Jemez River.

At Ponce de Leon, Solar America, Inc. is constructing a solar-assisted geothermal greenhouse as a State of New Mexico demonstration project. This project is in a preliminary design phase, and will probably use a surface heat exchanger for space heating. Secondary uses of the geothermal waters, if any, will probably use the waters directly. Method of disposal of geothermal waters is not discussed in the source document (Solar America, Inc., 1978).

At Faywood Hot Springs, the Southwestern New Mexico Services to Handicapped Children and Adults, working with a team of consultants from New Mexico State University, will construct a greenhouse as a state of New Mexico demonstration project in 1980. The engineering design for the geothermal system has not been completed at present, but' the system will utilize a surface heat exchanger, and discharge fluids to an irrigation holding pond and then to surface waters.

\subsubsection{Process Heat}

L'Eggs Products, Inc., a division of the Hanes Corporation is currently funded by the Department of Energy to perform engineering and economic studies for direct applications of geothermal energy. High temperatures $\left(180^{\circ}-212^{\circ} \mathrm{F}\right)$ are needed in the hosiery manufacturing process, medium temperature water $\left(130^{\circ}-180^{\circ} \mathrm{F}\right)$ may be used for space heating, and very high temperature water $\left(300-450^{\circ} \mathrm{F}\right)$ are needed for commercial air conditioning. The technological applications to be used at this plant are not yet determined. 


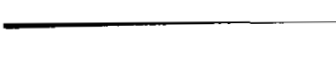

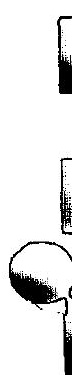




\subsection{REVIEW OF REGULATIONS THAT AFEECT GEOTHERMAL DEVELOPMENT AND ITS ENVIRONMENTAL IMPACT}

The vast majority of environmental baseline data now being collected in New Mexico is a direct result of the requirements of federal, state or local laws and regulations. These laws and regulations have direct and indirect effect on the development of geothermal resources in the state and on measuring environmental impact of this development.

For the purpose of this text, the laws and regulations are presented in this chapter by geothermal commercialization phases-exploration, development, construction and implementation, and operation rather than by the regulatory agency or the specific law. This will indicate what information is available from regulatory agencies at various phases of site-specific geothermal commercialization activity for the purpose of evaluating particular environmental impacts.

A11 state laws (except those for leasing state land which are not included in this text) apply to all state and private lands within New Mexico and most federal lands. Under treaty obligations, Indian lands may be, in some cases, exceptions to this rule. All federal laws that apply to the nation as a whole apply to all New Mexico land (i.e., air quality, water quality, and Antiquities Act) while the requirements for filing an Environmental Impact Statement under the National Environmenta1 Protection Act (NEPA) apply only to projects on federal land and/or projects financed with federal funds. Thus, it is possible for a geothermal development to be in complete compliance with state, local and federal laws and regulations without the Environmental Impact Statement process (and its required public review process) having occurred.

\subsection{Definition of a Geothermal Resource in New Mexico}

Geothermal resources are defined by the New Mexico Geothermal Resources Conservation Act (Section 71-5-1 NMSA 1978) as follows: "'Geothermal resources' means the natural heat of the earth, or the energy, in whatever form, below the surface of the earth present in, resulting from, created by or which may be extracted from, this natural heated fluids, brines, associated gases and steam, in whatever form, found below the surface of the earth, but excluding oil, hydrocarbon gas and other hydrocarbon substances."

\subsection{Resource Exploration Phase}

This phase of geothermal commercialization is the first step, and it involves the location and initial quantification of the nature of the resource deposit in order to project its useful purposes as a source of electrical generation or direct heat applications, or both. It is assumed that the reader is familiar with the regulations governing the 
securing of federal and state land leases for geothermal exploration. Therefore, this discussion is limited to those regulations and laws that are related to geothermal commercialization and the related environmental issues involved.

\subsubsection{Regulation of Exploration Wells}

Hannah et al. (1979) states that the Oil Conservation Division of the Energy and Minerals Department has authority over the regulation of all drilling, development, production and conservation of geothermal resources. For geothermal operations on Federal lands, the operator must comply with United States Government regulations and the operator must also comply with the applicable State rules and regulations as long as they do not conflict with the Federal regulations.

In general, a person who is a permanent resident of New Mexico and who will be responsible for maintaining copies of all well and operation records required by the OCD must file a Designation of Agent form. An out-of-state corporation must become licensed by the State Corporation Commission before it may engage in geothermal exploration within New Mexico. A plugging bond (for repair or closing of an errant weli) must be posted with the OCD, the amount of the bond varying with the nature and type of exploratory effort proposed. Form G-101, Application to Drill, Deepen, or Plug Back Geothermal Resources We11, must be filed with the OCD and a subsequent permit granted by the OCD if the application is in compliance with regulations.

For a complete view of these and other OCD regulations, the reader should obtain a copy of the Rules and Regulations for Geothermal Resources, Oil Conservation Division, Energy and Minerals Department, Box 2088, Santa Fe, New Mexico 87501. The following items are of particular interest from this publication:

\section{RULE 3. WASTE PROHIBITED}

(a) The production or handling of geothermal resources of: any type or in any form, or the handling of products thereof, in such a manner or under such conditions or in such an amount as to constitute or result in waste is hereby prohibited.

(b) Al1 owners, operators, contractors, drillers, transporters, service companies, pipe pulling and salvage contractors, and other persons shall at all times conduct their operations in the drilling, equipping, operating, producing, and plugging and abandoning of geothermal resource wells in a manner that will prevent waste of geothermal resources, and shall not wastefully utilize geothermal resources, or allow leakage of such resources from a geothermal reservoir, or from wells, tanks, containers, or pipe, or other storage, conduit, or operating equipment. 
RULE 4. PROTECTION OF LIFE, HEALTH AND THE ENVIRONMENT

Al1 geothermal operations, exploratory, drilling, and producing, shall be conducted in a manner that will afford maximum reasonable protection to human life, health, and to the environment.

RULE 102. DRILLING PERMIT

(b) No permit shall be approved for the drilling of any wells within the corporate limits of any city, town, or village of this state unless notice of intention to drill such well has been given to the duly constituted governing body of such city, town, or village or its duly authorized agent. Evidence of such notification shall accompany the application for a permit to drill (Form G-101).

RULE 104. WELL SPACING

\section{A. CLASSIFICATION OF WELLS}

Any we11, other than a geothermal observation well or a low-temperature thermal well, which is drilled a distance of one mile or more outside the boundary of any defined geothermal field and a distance of one mile or more beyond any well which is within one mile of such field, shall be classified as an exploratory well, and as such shall be spaced, drilled, operated, and produced in accordance with these Geothermal Rules and Regulations.

\section{B. ACREAGE AND WELL LOCATION REQUIREMENTS}

\section{(1) Exploration We11s}

A well classified as an exploratory well shall be located: on a designated drilling tract comprising at least 40 surface acres (being a quarter-quarter section of the U.S. Public Land Surveys, or a projection thereof, if on unsurveyed land), and sha11 be located at least 330 feet from the outer boundary of the quarter-quarter section, at least 660 feet from the nearest such other well drilling to or capable of producing from or injection into the same formation to which it is projected, and at least 100 feet from any pub1ic road, street, or highway dedicated prior to commencement of drilling.

(5) Geothermal Observation We1ls and Low-Temperature Thermal Wells

There shall be no restriction as to the placement of geothermal observation wells or low-temperature thermal wells. 


\section{NON-STANDARD LOCATLONS}

(1) The Division Director shall have the authority to grant an exception to the well location requirements of Rules B (1), (2), and (3) above without notice and hearing when such application is based upon topographical or geologic or engineering considerations.

(2) Applications for such administrative approval shall be filed in duplicate and shall be accompanied by a plat showing the owndership of surrounding lands (within a 990-foot radius of the proposed location if application is for exception to Rule 104B (1) Exploration Wells; within a 495-foot radius of the proposed location if application is for exception to Rule 104 B (2) Development Wells; within a 990-foot radius of the proposed location of application is for exception to Rule 104B (3) Injection Wells; and all drilling or complete wells thereon. If the proposed non-standard location is based upon topography, the plat shall also show the existent topographical conditions. If it is based upon geological or engineering considerations, the application shall be accompanied by a geologic or engineering analysis, explaining the necessity for the non-standard location.

(3) A copy of the application and accompanying plats and documents shall also be sent to the other owners, if any there be, within the above prescribed radii of the proposed non-standard location and the non-standard location upon receipt of waivers from the above other owners or if no such other owner has entered an objection to the non-standard location within 20 days after receipt of the application by the Division. If such objection is received, the matter will be set for hearing if the applicant so desires. If the Director is not convinced of the necessity or desirability of such exception, he may require supplemental information to justify the exception, or set the matter for hearing if the applicant so desires.

\section{OFFSETTING ACTION}

Whenever an exception to the well location requirements is granted, the Division after hearing may take such action as may be necessary to offset any advantage to the person securing the exception may gain over other owners within the same geothermal reservoir.

\section{E. SPECIAL ACREAGE AND WELL LOCATION REQUIREMENTS}

In order to prevent waste and protect correlative rights, the Division may, after notice and hearing, adopt different well location requirements and greater or lesser acreage dedication requirements than those contained in Rules $104 \mathrm{~B}$ (1), (2), and (3) above for a particular geothermal reservoir 
and may adopt special well location and acreage dedication requirements for a particular low-temperature thermal field.

\section{RULE 112. NOISE ABATEMENT}

Adequate noise abatement equipment shall be installed and maintained in good condition to reduce noise to a level approved by the Division or its representative on any drilling or producing geothermal resources well located within 1500 feet of a habitation, school or church.

\section{RULE 113. SAFETY REGULATIONS}

The well site around any drilling or producing well shall be kept clear of any rubbish or debris or fuel which may constitute a fire hazard. In any area where there is any likelihood of encountering unexpected hydrocarbons, the drilling mud and cuttings shall be stored in a pit a safe distance from the drilling rig. All waste shall be burned or disposed of in a manner as to avoid creating a fire hazard.

\section{RULE 116. DISPOSAL OF PRODUCED WATERS}

The disposal of highly mineralized waters produced from geothermal resource wells shall be in such a manner as to not constitute a hazard to surface waters or underground supplies of useable water.

RULE 601. GENERAL BLOWOUT PREVENTION

In areas where high subsurface pressures are known to exist, or where there is a history of lost circulation and/or blowouts, or in areas where subsurface pressures are not' known all proper and usual precautions shall be taken for keeping the well under control, including the use of blowout preventers and high pressure fittings attached to properly cemented casing strings.

Blowout preventers shall not be required for the drilling of low-temperature thermal wells, geothermal observation wells, and seismic, core, or other exploratory wells less than 500 feet deep.

\subsubsection{Regulation of Surface and Groundwaters}

Although the Oil Conservation Division has authority for regulating geothermal wells, the State Engineer has jurisdiction of the appropriation of all surface water of the State and groundwater within 
the boundaries of declared underground water basins (Hannah et al., 1979). Drilling of an exploration well, therefore, requires the filing of an Application for Permit with the State Engineer for any well on Federal, State or private land within the boundaries of a declared basin. If the application is in compliance, the exploratory permit will be granted, usually for one year's time. The driller of such a well must be licensed by the State Engineer (Water Resources Division).

Accidental spill of drilling mud or geothermal fluids would require the developer to obtain an Environmental Improvement Division discharge permit for a temporary spill and execute mitigating procedures for remedying the situation.

\subsubsection{State Archeologist Regulations}

The State Archaeologist, pursuant to the State Cultural Properties Act of 1977, issues permits to recognized archaeologists for survey work on State lands (Hannah et al., 1979). In New Mexico, it is a misdemeanor to excavate or destroy cultural property without such a permit. This act prohibits excavation of an archaeological site with mechanical earth moving equipment without a valid permit when a site is on private or state land. A private land owner can excavate on his own land without a permit, provided that no transfer of ownership for the intent of excavating archaeological sites has occured. Enforcement of the state act is in 1 imbo for private land status and is currently being appealed in state courts.

At the federal level, enforcement of the Antiquities and American Indians Religious Freedom Acts may come into conflict with geothermal resource exploration and development in some portions of New Mexico. The State Archaeologist, the Director of the New Mexico Laboratory of Anthropology in Santa Fe, could provide detailed information on the nature and amount of conflict that might be involved in a site-specific development.

\subsubsection{Pathway to Geotherma1 Exploration in New Mexico}

Figure 13 presents a time line and events chart of both the institutional procedures for exploration of geothermal resources in New Mexico under state and local regulations--including the regulatory agencies and specific actions required by regulation-- and the parallel time line and events required for the federal Environmental Impact Statement process.

Assuming that suitable leases have been obtained by the developer, the first state or local decision point is that of determining if the development is proposed for a declared water basin. If so, the State Engineer will issue an appropriate well driller license, if the developer qualifies, and a permit for a geothermal exploratory well. Then, if necessary, a state archeologist permit is issued and necessary salvage surveys are completed. An OCD geothermal well permit is 
CUMULATIVE TIME FOR FEDERAI EIS PREPARATION (where required)

Months $1-12$ ORORE

No EIS action requixed until resource is confirmed.

CUMULATIVE TIME FOR STATE AND LOCAL PROCEDURES

\begin{tabular}{ll|l|l|l|l|l|}
\hline Months & 1 & 2 & 3 & 4 & $5-12$ \\
\hline
\end{tabular}

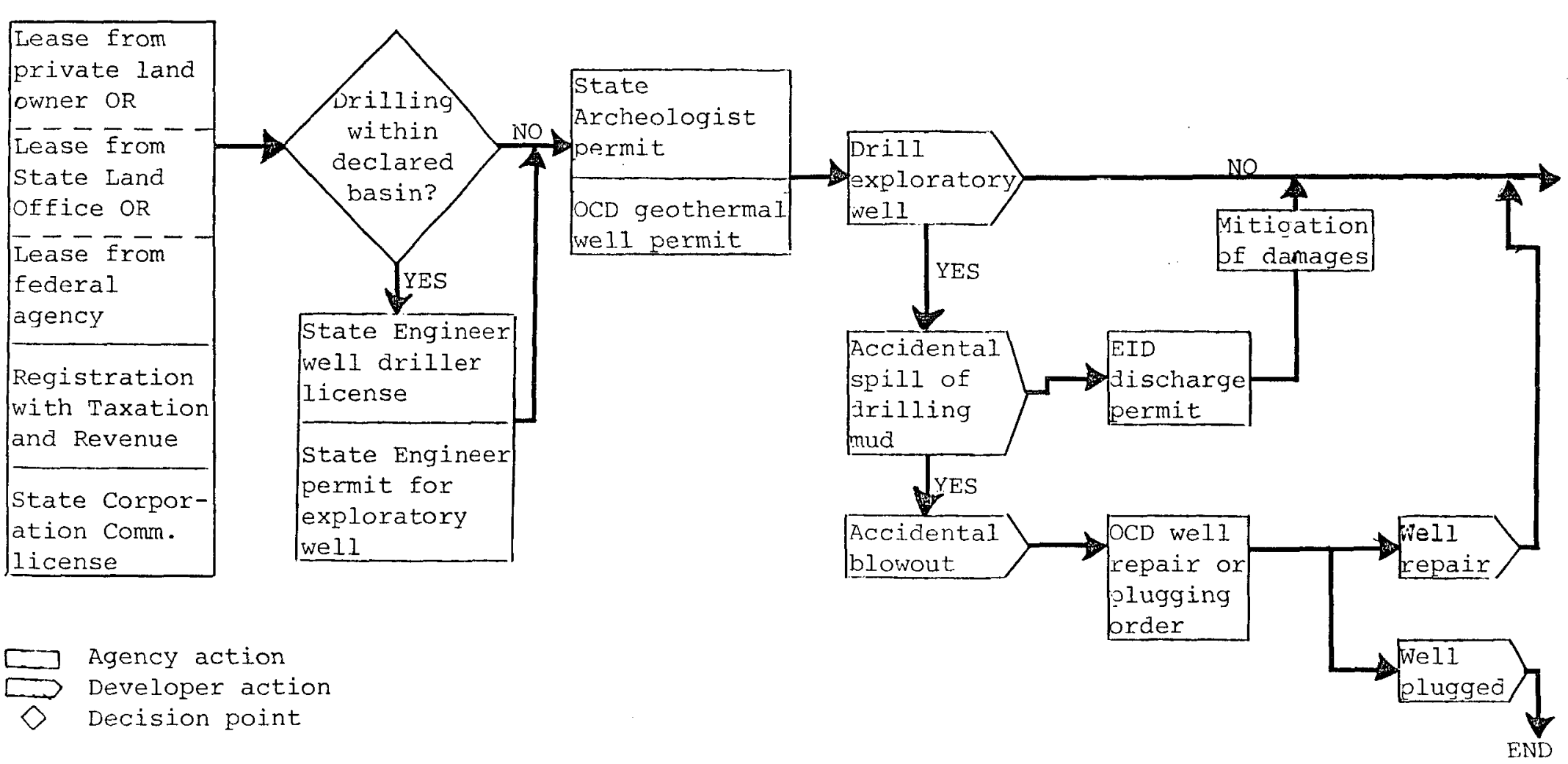

Figure 13. Time line and events chart (adapted from Hannah et al.,1979) of institutional procedures for exploration of geothermal resources in New Mexico under state and local regulations and of the EIS process. 
also issued. It should be noted that the State Engineer operates under the doctrine of prior appropriation, which separates the ownership of land from the right to use water on the land. It holds that water belongs to the public and is subject to appropriation for beneficial use. By applying water to a beneficial use, the developer acquires the right to use the water. The first entity to apply beneficial use has the first and prior right to the water. Permits can be granted to subsequent users only if the State Engineer finds that the granting will not impair the right of prior users. The OCD, however, operates under the doctrine of correlative rights, or the rights of an owner of a portion of a geothermal reservoir (by virture of OCD drilling permits) to recover his share of the land surface of the reservoir, as much as is practical, without undue waste. No one else should develop his holdings in such a way as to deprive the first owner of his rateable share.

\subsection{Resource Development Phase}

This is the second phase of geothermal development, involving the development of the geothermal well field to supply the proposed plant or facility. Some of the regulations discussed under the resource exploration phase (Section 4.2) will continue to apply to this phase.

\subsubsection{Regulation of Deve1opment We1ls}

The $0 i 1$ Conservation Division of the Energy and Minerals Department regulations continue to apply to geothermal development wells (Oil Conservation Division, 1979). Of particular interest are the following:

RULE 3. WASTE PROHIBITED.

Sections (a) and (b) apply to development wells (Section 4.2.1).

RULE 4. PROTECTION OF LIFE, HEALTH AND THE ENVIRONMENT:

Statement applies to development we11s (Section 4.2.1).

RULE 102. DRILLING PERMIT.

Section (b) applies to development wells (Section 4.2.1).

RULE 104. WELL SPACING.

\section{A. CLASSIFICATION OF WELLS.}

Any wel1, other than a geothermal observation well or a low-temperature thermal well, which is not an exploratory we 11 as defined above, shall be classified as a development well, unless such well is being drilled for injection or disposal purposes, in which case it will be appropriately classified. 
Any well classified as a development well or injection or disposal well within a given geothermal field shall be drilled, operated, and produced in accordance with these Geothermal Rules and Regulations unless special rules in conflict therewith have been promulgated for such field, said special rules then being applicable.

B. ACREAGE AND WELL LOCATION REQUIREMENTS.

\section{(2) Development We11s}

A well classified as a development well shall be located on a designated drilling tract comprising of at least 10 surface acres (being a quarter-quarter-quarter section of the U.S. Public Land Surveys or a projection thereof if on unsurveyed land), and shall be located at least 165 feet from the outer boundary of the quarter-quarter-quarter section, at least 330 feet from the nearest well drilling to or capable of production from or injection into the same geothermal reservoir to which it is projected, and at least 100 feet from any public road, street, or highway dedicated prior to commencement of drilling.

\section{(3) Injection Vells}

Injection wells drilled for the purpose of injection into a geothermal reservoir shall be located at least 330 feet from the outer boundary of the lease or drilling parcel and at least 100 feet from any public road, street, or highway dedicated prior to commencement of drilling.

(4) Disposal We11s

There shall be no restriction as to the placement of geothermal disposal wells.

C. NON-STANDARD LOCATIONS.

Section (1), (2) and (3) apply to development wells (Section 4.2.1).

The Rules for offsetting action special acreage and well location requirements, noise abatement, safety regulations, disposal of produced waters and general blowout prevention (Section 4.2.1) also apply to development wells.

\subsubsection{Regulation of Surface and Groundwaters}

\subsubsection{Water Quantity}

Water in New Mexico is a commodity or property right owned by the people. Local Agencies and public districts which have responsibilities 
for water development and conservation are: water users associations. water and sanitary districts, drainage districts, irrigation districts, conservancy districts, artesian conservancy districts, and community ditches or acequias.

Water rights are administered by the State Engineer in accordance with the provisions of the constitution and the statutes; the adjudications of the courts; and the terms of interstate compacts, licenses and permits.

The general framework of the administrative system remains the same as in the territorial era. Changes that have been made were largely technical with little basic alteration in policy. The Manual of Rules and Regulations Governing the Appropriation and Use of Surface Waters and a similar manual with respect to groundwater provide the following:

Al1 natural waters flowing in streams and water courses in New Mexico and the waters of underground streams, channels, artesian basins, reservoirs, or lakes having reasonable, ascertainable boundaries belong to the public and are subject to appropriation for beneficial use.

Beneficial use is the basis, measure, and 1 imit of the right to use water. No water right, therefore, may be granted or claimed for more than the amount that can be beneficially used. Priority in times of appropriation shall give the better right.

Al1 existing rights to the use of water for beneficial purposes in New Mexico were recognized and confirmed by the State Constitution at the time of its adoption. Existing rights to beneficial use of underground waters are recognized and confirmed by the statutes.

The State Engineer is empowered to make all rules and regulations necessary administer the duties devolved upon his office, and New Mexico Water Law provides the following:

Excepting stored waters, failure of any owner to beneficially use all or any part of the water in which he has a vested right for a period of four consecutive years constitutes forfeiture if the failure to beneficially use the water persists one year after notice and declaration of nonuse given by the State Engineer, and such unused water shall revert to the public; except that forfeiture does not necessarily occur should such nonuse be caused by circumstances beyond the owner's control.

Specific regulations regarding surface water promulgated by the State Engineer are as follows:

The unauthorized use of water to which another is entitled, or the willful waste of water to the detriment of 
another or of the public is a misdemeanor. Excessive, wasteful, and otherwise nonbeneficial uses do not constitute a valid water right.

A11 water appropriated for irrigation purposes, except as otherwise provided by written contract between the owner of the land and the owner of any ditch, reservoir, or other works for the storage or conveyance of water is appurtenant to the land upon which it is used and shall so continued as long as it can be beneficially used on or until it is lawfully severed from the land. Water which is appurtenant to certain lands may not be transferred to other lands or used for other beneficial purposes excepting the consent of the owner of the land and as provided by law.

No appropriation of water shall be exercised to the detriment of anyone holding prior, valid, and existing rights to the use of the waters of a stream system.

Excepting for water rights acquired prior to March 19, 1907 , any right to the use of public waters must originate by application to the State Engineer as provided by statute. Unauthorized use shall be a misdemeanor.

The public is notified of proposed appropriations by publication in a newspaper of general circulation in the stream system and any water right owner who feels that the use of water under such application would be detrimental to this prior right may file a protest thereto. After due consideration of the facts, the State Engineer shall approve or reject the application. His decision is subject to appeal to the District Court.

It is unlawful to commence any construction of works until the formal application to appropriate water has been approved and signed by the State Engineer.

The diversion and distribution of water for irrigation and domestic purposes in New Mexico is a public purpose, and an appropriator may exercise the right of eminent domain to acquire rights-of-way for canals, ditches, reservoirs, etc., necessary to accomplish such purpose.

License to appropriate water is issued by the State Engineer after the works are satisfactorily completed and the water is applied to benefical use.

To the end that the waters of the several stream systems of the State may be so utilized as to prevent waste and damage and in order that the benefits of such waters be distributed among the landowners along said streams and equitably as possible without interfering with vested rights, the natural right of the people living in the upper valleys to impound and 
utilize a reasonable share of such waters has been recognized and declared, subject always to the provisions of the water right statutes.

The appropriation statute does not apply to stockmen who shall build or construct tanks or ponds for watering stock which do not exceed 10 acre-feet in capacity. The owners are, however, at all times responsible for any detriment or damage to prior rights which may result from the contruction of and storage of water in such stock ponds.

The State Engineer has the right and duty of supervision of the apportionment of water according to licenses issued by his office and to the adjudications of the courts. Although water rights acquired prior to March 19, 1907, may be adjudicated only by the courts, all such rights are subject to regulation, adjudication, and forfeiture for nonuse as provided in the statutes; provided, that in all cases where the rights to the use of the waters in interstate streams of owners of land not included in conservancy districts, irrigation districts, or federal reclamation projects have been the subject of litigation in the state or federal courts of an adjoining state, the State Engineer shall assume control of all or any part of such interstate streams and the diversions and distribution of the waters of the same in the public interest.

Following are general principles of administration of groundwater by the State Engineer

Wells may be drilled and groundwaters appropriated for beneficial uses outside of the boundaries of declared areas of the state without the appropriator making application to the State Engineer, subject only to prior and existing rights within such areas.

Existing rights to beneficial use of underground waters are recognized and confirmed by the statutes. The State Engineer permits the filing of declarations of rights. Any new right to the use of waters in a declared underground water basin must originiate by application to the State Engineer.

Any right to the use of underground waters shall be subject to the valid and existing rights to the use of such waters by all prior appropriators thereof. Excessive, wasteful, or otherwise nonbeneficial use does not constitute a valid water right.

The public is notified of proposed appropriations by publication of each application in a newspaper of general circulation in the county which the proposed well will be located and any owner of water rights who feels that the use of water under such proposal will impair his rights may file a protest thereto. 
If no objection or protest is filed, the State Engineer shall approve the application in whole or in part if he finds that there are unappropriated waters and that the proposed app1ication will not impair existing rights. If protest has been filed and applicant and protestant are unable to reach an agreement, the State Engineer shall hold a hearing on the application after which he will either approve the application or deny it. His decision is subject to appeal to the District Court.

It is unlawful to commence the construction of any well for the appropriation of underground water in declared basins until the application has been approved.

License to appropriate underground water is issued by the State Engineer after he has received satisfactory evidence that the works have been completed and the water applied to beneficial use within the terms of the permit.

The right to the use of underground water for irrigation purposes is appurtenant to the land on which it is used and shall so continue as long as it is beneficially used or until it is lawfully severed from the land. Water which is appurtenant to certain lands maybe transferred to other lands or other uses only as provided by law and with the consent of the owner of the land.

Utilization of water in the state is subject to provisions of compacts entered into between New Mexico and other states on the Rio Grande, Costilla Creek. Pecos River, Colorado River, Upper Colorado River Basin, Animas-La Plata Project, La Plata River, and Canadian River. Discussions of these compacts are contained in House Document No. 319, 90th Congress, 2nd Session. Treaties, adjudications, "court decrees, and other litagations are also discussed in the House Document.

Generally, when information is needed on a compact, it must be reviewed in its entirety because of the relation of one article to another. Therefore, in reference to the eight compacts, only the states involved and dates of ratification by New Mexico are given here.

1. Colorado River Compact. This compact was ratified by New Mexico, Laws of 1923, Chapter 6, and amended by Laws of 1925, Chapter 78. Signatories to the compact are the states of Arizona, California, Colorado, Nevada, New Mexico, Utah, and Wyoming.

2. La Plata River Compact. This compact, ratified by New Mexico by Laws of 1923, Chapter 7, is between the states of Colorado and New Mexico.

3. Rio Grande Compact. Signatories to the compact are the states of Colorado, New Mexico and Texas. New Mexico ratified the document originally by Laws of 1939, Chapter 33. The compact was subsequently amended by laws of 1945 , Chapter 60 . 
4. Costilla Creek Compact. The compact, ratified by New Mexico, Laws of 1945, Chapter 51, amended by Laws of 1963, Chapter 256, is a compact between the states of Colorado and New Mexico.

5. Upper Colorado River Basin Compact. This compact was ratified by New Mexico by Laws of 1949 , Chapter 5. Parties to the compact are the states of Colorado, New Mexico, Utah, Wyoming, and Arizona.

6. Pecos River Compact. An earlier compact was conditionally ratified by New Mexico, Laws of 1933, Chapter 166; the present compact was ratified by Laws of 1949 , Chapter 6 . It is an agreement between the states of Texas and New Mexico.

7. Canadian River Compact. This compact was ratified by New Mexico by Laws of 1951, Chapter 4. It apportions the waters of the Canadian River among the states of New Mexico, Texas and Oklahoma.

8. Animas-La P1ata Project Compact. This compact, ratified by New Mexico by Laws of 1969 , Chapter 57 , is between the states of Colorado and New Mexico. The Animas-La Plata Project is a federal reclamation participating project under the Colorado River Storage Project Act.

Three international treaties between the United States and Mexico affect water use in New Mexico. The first treaty, ratified in 1906 by the United States and in 1907 by Mexico, obligates the United States to deliver annually 60,000 acre-feet of water in the bed of the Rio Grande at the headworks of the Acequia Madre Diversion Dam located above the city of Juarez, Mexico. Provisions are contained for the sharing of shortages in case of extraordinary drought or serious accident to the irrigation system in the United States. The second treaty, ratified in 1933, launched cooperative efforts by the two nations to relieve the towns and agricultural lands in the E1 Paso-Juarez Valley from flood dangers. Stabilization of the international boundary was obtained by rectifying the Rio Grande's channel to confine it between two parallel levees. Flood control was improved by construction of Caballo Dam. The third treaty, executed in 1944, and covering the delivery of Colorado River water to Mexico, affects New Mexico in its capacity as a Colorado River Basin state.

Portions of New Mexico are affected by water rights issues embodied in historical treaties between the federal government and various Indian tribes. Some of these treaty obligations are currently being tested in the federal courts. It would be wise, for developers and regulatory agencies alike, to be aware of the current status of such litigation.

\subsubsection{Water Quality}

Policy for water pollution control programs, as provided by the Water Quality Act (74-6-1) (NMSA, 1978) is established by the Water Quality Contro1 Commission, which consists of eight state agency directors or their designees and one public member appointed by the 
Governor. Although a number of agencies are involved in environmental issues, by far the bulk of the regulatory effort involves the Environmenta1 Improvement Division.

The Water Quality Control Commission has been delegated principal authority for water quality control in New Mexico. This commission has the power to adopt a comprehensive water quality program; adopt water quality standards; promulgate regulations to prevent or abate water pollution; classify waters for certain purposes; receive and allocate funds made available by the federal government; and grant variances from regulations of the commission.

Under direction of the commission and the administration of the Environmental Improvement Division, stream standards for the Rio Grande and Pecos, San Juan-La Plata-Animas, Canadian, and Gila-San Francisco Rivers in New Mexico were approved as federal standards in 1969. Certain effluent regulations have also been adopted. In August 1973 the commission revised the stream standards as required by the Water Quality Act Amendments of 1972. The revised standards have also been approved as federal standards.

State Water Quality Control Commission regulations require several permits or notifications for discharge of water contaminants to surface or groundwater (Hannah et al., 1979):

1-201 "Notice of Intent to Discharge," requires a developer intending to make a new or change in water contaminant discharge to file a notice with the water Quality Section.

1-202 "Filing of P1ans and Specifications-- Sewerage Systems," requires the filing of plans and specifications for sewerage systems, prior to commencement of construction, with the Water Quality Section. This notification and permit applies to geothermal development only if construction of sewage treatment facilities are incorporated into development or operational features.

1-203 "Notification of Discharge-- Removal," requires that any person in charge of a facility, as soon as he has knowledge of a spill of any water contaminant, shall immediately notify the Chief, Water Quality Section, of the spill and take appropriate steps to contain, remove and mitigate the damage caused by the spill.

2-100 "Applicability of Regulations," applies to the State's surface discharge regulations to those discharges which are not subject to the Federa1 National Pollutant Discharge Elimination System (NPDES) and establishes parameter effluent levels for these discharges. EID has not legally taken over administration of the NPDES program, although it assists the EPA in the day-to-day operations of the program.

3-101 "Regulations for Discharges Onto or Below the Surface of the Ground," are aimed at protecting the quality of all groundwater in New Mexico with an existing concentration of $10,000 \mathrm{mg} / 1$ or less Total Dissolved Solids (TDS). The regulations establish groundwater standards 
for specific parameters and require an approved discharge plan prior to commencement of discharge. Monitoring and reporting requirements are included. The OCD reviews and approves groundwater discharge plans for geothermal projects on behalf of the WQCC. OCD has 60 days after receipt of notice of intent to discharge to notify the developer if a discharge plan is required. For good cause, the OCD may allow a developer to discharge without a discharge plan for up to 120 days.

\subsubsection{Regulations for Establishment of a Public Utility}

The Public Utility Act of 1941 (Hannah et al., 1979) created the Public Service Commission as the regulatory agency having decisive powers over the securities issued and services and rates provided by utilities. In order to operate a utility as a profit-making entity, specifically as a geothermal power producting facility, one must be licensed by the Public Service Commission. The PSC does not have jurisdiction over municipally owned utilities or utilities on Indian lands. A Certification of Convenience and Necessity may be obtained no more than one year before the commencement of construction of the power facility. If an already existing, licensed utility wishes to expand operation to include a geothermal power-producing facility, for less that $230 \mathrm{MW}$ capacity, it may request commission assessinent under General order 10 for approval and for more than $230 \mathrm{MW}$, it must petition for the full certificate.

THE PSC has jurisdiction over all water, gas and electric public utilities (except those that are municipally-owned) and specifically over the distribution of steam through a pipeline. A district heating system would come under the jurisdiction of the PSC (except, presumably, if municipally-owned). No such systems yet exist in New Mexico, so this jurisdiction is untested.

\subsubsection{Pathway to Development of a Geothermal Resource Area in New Mexico}

Figure 14 presents a time line and events chart of both the institutional procedures for development of geothermal resource areas in New Mexico under state and local regulations, including the regulatory agencies and specific actions required by regulation, and the parallel time line and events required for the federal Environmental Impact Statement process.

As soon as the resource is proven and the decision made to pursue further development activity, the initiation of a data collection program for the EIS should occur, if this process is required in the commercialization effort that is proposed. The EIS process can take up to 36 months from the beginning of data collection through submission by the developer to the federal land managment agency or lead agency. Concurrently, a series of state and local procedures are executed. (Note: If no EIS is required, the state and local procedures will be pursued separately.) 
CUMULATIVE TIME FOR FEDERAL EIS PREPARATION (where required)

\begin{tabular}{|c|c|c|c|c|}
\hline Montins & 13 & $14-24$ & $25-36$ & $37-48$ \\
\hline $\begin{array}{l}\text { Begin } \\
\text { data }\end{array}$ & tal & & $\begin{array}{l}\text { Adequate data for } \\
\text { developer's Applicant } \\
\text { Environmental Analysis } \\
\text { (12-24 months) }\end{array}$ & $\begin{array}{l}\text { AEA submitted to } \\
\text { federal land management } \\
\text { agency or lead agency } \\
(6-12 \text { months })\end{array}$ \\
\hline
\end{tabular}

CUMULATIVE TIME FOR STATE AND LOCAL PROCEDURES

\begin{tabular}{ll|l|l|l|l|l|l|l|l|l|l|l|l|l|l|}
\hline Months & 13 & $25-36$ & & 47 & 48 \\
\hline
\end{tabular}

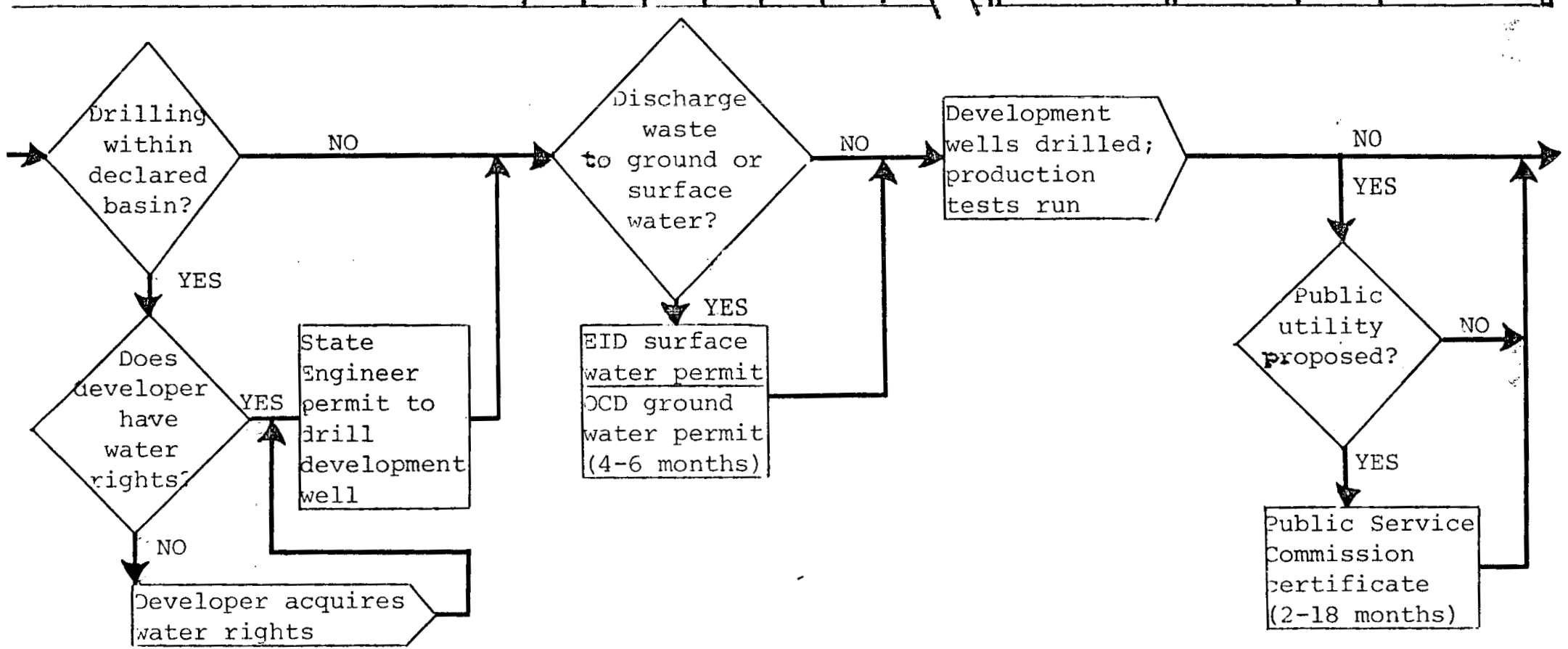

$\therefore$ Agency action

$\longrightarrow$ Developer action

$\diamond$ Decision point

Figure 14. Time line and events chart (adapted from Hannah et a1.,1979) of institutional procedures for development of geothermal resource area in New Mexico under state and local regulations and of the EIS process. 
If the drilling is within a declared surface or groundwater basin, issues of water rights must be resolved, and if necessary, the developer must acquire the necessary water rights. This process of acquiring water rights can take an undetermined amount of time, thus lengthening the time line. The State Engineer will issue a permit to drill a development well when water rights issues are settled. If the development strategy requires discharge of waste to ground or surface water, the required EID (for surface water) and OCD (for groundwater) permits must be secured. Accidental spills or blowouts would be regulated and mitigated under the procedures indicated for exploratory well drilling (Section 4.2.4).

If a new public utility is proposed for the operation of either an electrical generation facility or a district heating facility, petitions must be made to the Public Service Commission for a Certificate of Convenience and Necessity. (Note exceptions in Section 4.3.3.)

By the end of a maximum of 48 months (four years), the way should be clear for the construction and implementation of the proposed facilities. Diligence on the part of the developer will lead to the completion of state and local regulation requirements and the preliminary stages of the EIS process concurrently.

\subsection{Construction and Implementation Phase}

The third step of geothermal commercialization involves the construction of project facilities. In this phase, the time line for the EIS process is significantly longer than that for state and local regulations, with construction of facilities delayed until the EIS process is complete.

\subsubsection{Local Zoning Codes}

There are basically two types of local zoning codes that would affect geothermal development within the boundaries of a town or city: 1) building construction codes and covenents and 2) noise pollution regulations. At least 25 New Mexico cities and towns have adopted construction codes that are as stringent as the existing state codes, or more so. Developers of geothermal facilities within cities with building codes and special zoning laws should become familiar with these regulations and work with local officials in the resolution of conflicts so that the appropriate building permits may be acquired prior to facility construction.

Under the Noise Control Act of 1972, the Environnental Protection Agency is responsible for conducting research on the effects of noise. This act is not enforced statewide, however, and only a few New Mexico cities have adopted any local noise regulations and standards. Those areas with noise abatement regulations are Albuquerque, Farmington, Los Alamos, Socorro and Red River. Most of these regulations concern 
vehicular noise pollution control and may, in fact, have no effect on geothermal commercialization activities. Other New Mexico communities may develop similar regulations in the near future. The most active in this direction are Espanola, Gallup, Grants, Las Cruces, Las Vegas, Portales, Santa Fe and Taos.

\subsubsection{Construction Industries Commission Building Codes}

The Construction Industries Commission is responsible for the adoption of statewide building codes and the issuance of building permits for the construction of geothermal facilities. Under the law establishing the Commission, the Construction Industries Licensing Act, the public is protected against substandard or hazardous construction, alteration, installation, connection, demolition or repair work. Since the building codes are not incorporated into state law, they may be amended by simple majority of the commission at any time it deems feasible. Conflicts with existing building codes and planned geothermal facilities are likely to center around building design parameters, heat loss, and heating/cooling system mechanics. Such conflicts, however, should be resolvable through appropriate interaction with the Commission.

\subsubsection{Environmenta1 Improvement Division Air Quality Regulations}

A developer must obtain a permit from the EID prior to construction of or modification of any source of air contaminants, which if uncontrolled, would result in an emission of the contaminant greater than ten pounds per hour or twenty five tons per year, or would result in the emission of a hazardous air pollutant. Sufficient information must be submitted by the developer to demonstrate a projection model of the levels of emissions for comparison with the ambient conditions and standards. A permit may be denied if it appears the emissions will not meet applicable regulations of the New Mexico Air Quality Control Act, if the emissions of a contaminant are in excess of a Federal standard, or if the project will cause or contribute to air contaminant levels in excess of any national, state or Class A county (Bernalillo) ambient air quality standards.

State and federal standards defining ambient air quality are presented in Table 8 . This includes the five pollutants monitored in New Mexico: total suspended particulate, sulfur dioxide, carbon monoxide, ozone, and nitrogen dioxide. Hydrogen sulfide is not monitored in New Mexico, although a standard of $0.01 \mathrm{ppm} / \mathrm{one}^{-h o u r}$ average exists.

Air quality is further protected by the 1977 Clean Air Act Amendments which became law on August 7, 1977. Two major provisions of this act are the Prevention of Significant Deterioration and the Determination of Non-Attainment Areas (areas that do not meet national ambient air quality standards for a pollutant). 
Table 8. Definition, unity of measurement, and state and federal regulations concerning air pollutants that may possibly be associated with geothermal development.

\begin{tabular}{|c|c|c|c|c|}
\hline Pollutant & $\begin{array}{l}\text { Definition } \\
\text { or Formula }\end{array}$ & $\begin{array}{l}\text { Measurement } \\
\text { Unit }\end{array}$ & $\begin{array}{c}\text { State } \\
\text { Regulations } \\
\end{array}$ & $\begin{array}{c}\text { Federal } \\
\text { Regulations } \\
\end{array}$ \\
\hline arsenic & As & $\mu \mathrm{g} \cdot \mathrm{m}^{-3}$ & $\begin{array}{l}30 \text { days }{ }^{\text {avg }} \\
10 \mu \mathrm{g} \cdot \mathrm{m}^{-3}\end{array}$ & \\
\hline beryllium & $\mathrm{Be}$ & $\mu q \cdot m^{-3}$ & $\begin{array}{l}30 \text { day avg } \\
0.01 \mu \mathrm{\mu g} / \mathrm{m}^{3}\end{array}$ & \\
\hline boron & B & $\mu g \cdot m^{-3}$ & $\begin{array}{l}30 \text { day avg } \\
10 \mu g \cdot m-3\end{array}$ & \\
\hline carbon monoxide & $\mathrm{CO}$ & ppm & $\begin{array}{l}8 \mathrm{~h} \text { avg } \\
8.7 \mathrm{ppm}\end{array}$ & $\begin{array}{l}8 \text { h avg } \\
9 \text { ppm }\end{array}$ \\
\hline $\begin{array}{l}\text { hydrogen } \\
\text { sulfide }\end{array}$ & $\mathrm{H}_{2} \mathrm{~S}$ & ppm & $\begin{array}{l}1 \mathrm{~h} \mathrm{avg} \\
0.01 \mathrm{ppm}\end{array}$ & \\
\hline $\begin{array}{l}\text { sulfur } \\
\text { dioxide }\end{array}$ & $\mathrm{SO}_{2}$ & ppm . & $\begin{array}{l}24 \mathrm{~h} \mathrm{avg} \\
0.10 \mathrm{ppm}\end{array}$ & $\begin{array}{l}24 \mathrm{~h} \text { avg } \\
0.14 \mathrm{ppm}\end{array}$ \\
\hline $\begin{array}{l}\text { nitrogen } \\
\text { dioxide }\end{array}$ & $\mathrm{NO}_{2}$ & ppm & $\begin{array}{l}24 \mathrm{~h} \text { avg } \\
0.10 \mathrm{ppm}\end{array}$ & $\begin{array}{l}\text { annual arithmetic mean } \\
0.05 \mathrm{ppm}\end{array}$ \\
\hline $\begin{array}{l}\text { photochemical } \\
\text { oxidants (ozone) }\end{array}$ & $\left(0_{3}\right)$ or $0_{x}$ & ppm & $\begin{array}{l}\mathrm{h} \text { avg } \\
.06 \mathrm{ppm}\end{array}$ & $\begin{array}{l}1 \mathrm{~h} \mathrm{avg} \\
0.08 \mathrm{ppm}\end{array}$ \\
\hline hydrocarbons & $\ldots{ }_{x}{ }^{H} x$ & ppm & $\begin{array}{l}3 \mathrm{~h} \text { avg } \\
0.19 \mathrm{ppm}\end{array}$ & \\
\hline
\end{tabular}

1 Statewide except in Pecos-Permium Basin where standards are $1 / 2 \mathrm{~h}$ avg. $0.10 \mathrm{ppm} ; 1 / 2 \mathrm{~h} \mathrm{avg} .0 .03 \mathrm{ppm}$ within corporate 1 imits; and $1 / 2 \mathrm{hr}$ avg $0.03 \mathrm{ppm}$ within 5 miles of cities with populations of 20,000 or more. 
Table 8. (Continued)

\begin{tabular}{|c|c|c|c|c|}
\hline Pollutant & $\begin{array}{l}\text { Definition } \\
\text { or Formula } \\
\end{array}$ & $\begin{array}{c}\text { Measurement } \\
\text { Unit } \\
\end{array}$ & $\begin{array}{c}\text { State } \\
\text { Regulations } \\
\end{array}$ & $\begin{array}{c}\text { Federal } \\
\text { Regulations } \\
\end{array}$ \\
\hline $\begin{array}{l}\text { heavy } \\
\text { metals }\end{array}$ & & $\mu \mathrm{g} \cdot \mathrm{m}^{-3}$ & $\begin{array}{l}30 \mathrm{~d} \mathrm{avg}_{\mathrm{i}} \\
10 \mu \mathrm{q} \cdot \mathrm{m}^{-3}\end{array}$ & \\
\hline $\begin{array}{l}\text { total suspended } \\
\text { particulate }\end{array}$ & TSP & $\mu g \cdot m^{-3}$ & $\begin{array}{l}24 \mathrm{~h} \text { avg } \\
150 \mathrm{~g} / \mathrm{m}^{3}\end{array}$ & $\begin{array}{l}260 \mu g / m^{3} \\
24 \mathrm{~h} \mathrm{avg}\end{array}$ \\
\hline $\begin{array}{l}\text { total reduced } \\
\text { sulfur }\end{array}$ & $S$ & ppm & $\begin{array}{l}1 \mathrm{~h} \text { avg } \\
.003 \mathrm{ppm}\end{array}$ & \\
\hline mercury & $\mathrm{Hg}$ & $\mu g \cdot m^{-3}$ & $\begin{array}{l}30 \mathrm{~d} \cdot \operatorname{avg} \\
10 \mathrm{\mu g} \cdot \mathrm{m}^{-3}\end{array}$ & \\
\hline methane & $\mathrm{CH}_{4}$ & ppm & $\begin{array}{l}3 \mathrm{~h} \text { avg } \\
0.19 \mathrm{ppm}\end{array}$ & \\
\hline ethane & $\mathrm{C}_{2} \mathrm{H}_{6}$ & ppm & $\begin{array}{l}3 \mathrm{~h} \mathrm{avg} \\
0.19 \mathrm{ppm}\end{array}$ & \\
\hline fugitive dust & $\begin{array}{l}\text { solid airborne } \\
\text { particulate } \\
\text { matter emitted } \\
\text { as the result } \\
\text { of processing } \\
\text { operations } \\
\text { from any source } \\
\text { including waste } \\
\text { piles }\end{array}$ & $7 \mathrm{bs} / \mathrm{h}$ & $\begin{array}{l}10 \text { lbs } / \mathrm{h} / 10,000 \\
\text { lbs, aggregate } \\
\text {-inciuding } \\
\text { asphalt, mica, } \\
\text { pumice and } \\
\text { perlite }\end{array}$ & \\
\hline
\end{tabular}


The Prevention of Significant Deterioration and the Visibility Protection sections of the 1977 Clean Air Act protect air which is cleaner than minimum levels required to meet national standards. Since New Mexico has few areas where pollutants exceed the standards, this act may do more to protect New Mexico's clean air than, perhaps, a11 other legislation. The Visibility Protection area is especially important in areas with scenic qualities. A visual target--such as a mountain range--illustrates the need for adequate visibility in providing the viewer some means to assess the air quality. In urban areas, or other areas where visual targets are few, this aspect of air quality is not deemed to be as important.

Previous legislation at both state and federal levels had been aimed at the abatement of problems rather than the prevention of air pollution. However, the Prevention of Significant Deterioration has provisions to:

1. protect public health and welfare from any actual or potential adverse effect, notwithstanding attainment and maintenance of al1 national ambient air quality standards;

2. to preserve, protect and enhance the air quality in areas of special concern;

3. to ensure that economic growth will occur in a manner consistent with preservation of existing clean air resources;

4. to assure that emissions from any source in any state will not interfere with the prevention of significant deterioration in any other state; and

5. to assure that any decision to permit increased air pollution is made only after careful evaluation and opportunity for public participation (State of New Mexico, Air Quality Section, 1977).

The act further outlines ceilings which cannot be exceeded and provides increments which define allowable increases for air pollution above a present baseline air quality level. These increments are:

1. Class I. This increment is intended to apply to an area which is to remain pristine, and would allow almost no increase in air contaminant levels (Figure 15).

2. Class II. This increment is applicable where moderate development is desired. It would allow almost any type of well-controlled industry.

3. Class III. This increment applies where intensive growth is desired.

Of these classifications, Class $I$ is probably the most important to geothermal development. Areas, such as international parks, wilderness 


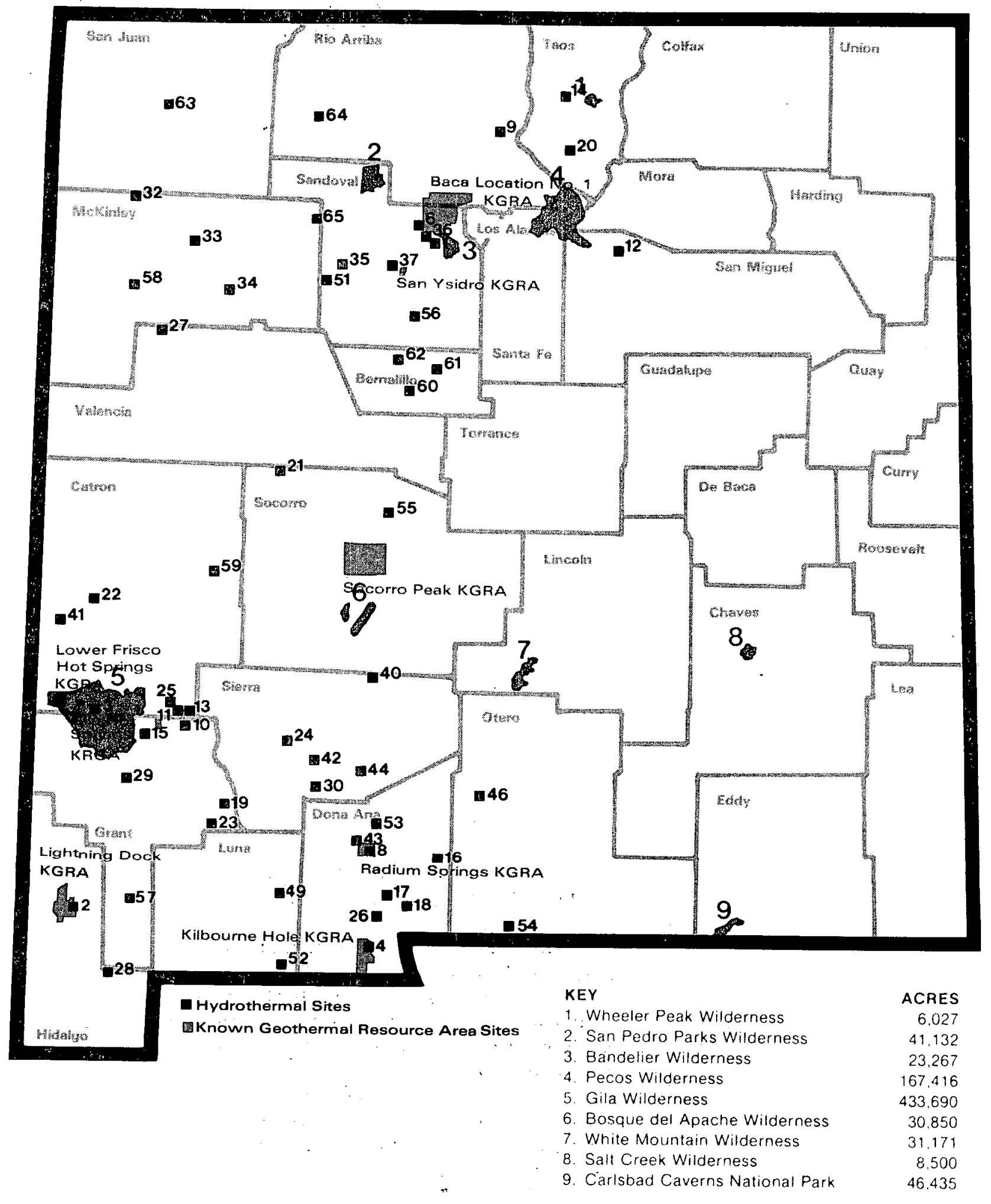

Figure 15. Mandatory Class I, under the Prevention of Significant Deterioration and the Visability Protection sections of the 1977 Clean Air Act in New Mexico. 
areas which exceed 5,000 acres, and national parks which exceed 6,000 acres, are Mandatory Class $I$ and cannot be redesignated. Within New Mexico there are nine such areas (Wheeler Peak Wilderness, San Pedro Parks Wilderness, Bandelier Wilderness, Pecos Wilderness, Gila Wilderness, Bosque del Apache Wilderness, White Mountain Wilderness, Salt Creek Wilderness and Carlsbad Caverns National Park). Since the Clean Air Act Amendments establish a national goal of the prevention of any future and remedying of any existing impairment of visibility due to manmade air pollution, this may indeed complicate geothermal development in areas near these sites. As can be seen in Figure 15, several potential geothermal sites either occur on or near these Mandatory Class I areas, which may limit geothermal development.

The 1977 Clean Air Act also requires each state to designate all areas that do not meet federal air quality standards for five specified pollutants (total suspended particulate, sulfur dioxide, carbon monoxide, nitrogen dioxide and photochemical oxidants). These areas are called "non-attainment areas". In New Mexico, non-attainment for the following pollutants may only inhibit geothermal development, if such pollutants are associated with a particular geothermal resource. They include:

1. carbon monoxide in areas around Las Cruces, Farmington, Santa Fe and Bernalillo County in its entirety;

2. total suspended particulates around potash refineries in the Carlsbad area, in Albuquerque and in a $4.5 \mathrm{mile}$ radius around the Kennecott Corporation smelter at Hurley;

3. sulfur dioxide in a 2.5 mile radius of the Four Corners Power Plant, and a 4.5 mile radius around the Kennecott Copper Corporation smelter at Hurley;

4. photochemical oxidants in Albuquerque, Ias Cruces, and portions of Lea and Eddy Counties. The EPA has "automatically" designated all urban areas in the U.S. with populations over 200,000 as non-attainment areas for this pollutant.

A stated objective of the New Mexico Air Quality Control Program is to insure source compliance with New Mexico air quality regulations. The Air Quality Control Act requires that an effort be made to seek voluntary compliance from the source. When such compliance cannot be obtained, the Act allows for seeking an injunction and penalties of up to $\$ 1000$ for each violation of a regulation. In an effort to voluntarily comply with regulations, a source may request relief from a regulation for a specified time period because of economic hardship, or in order to modify, upgrade or install additional air pollution equipment. In other instances, relief will be based on the lack of availability of technology. 


\subsubsection{Other Federal Regulations}

Noise level regulations and ambient air quality regulations have been set for worksites and industrial operations through the Occupational Safety and Health Act (OSHA), administered by the Department of Labor. Several other federal agencies have standards for noise pollution and abatement, Housing and Urban Development (HUD) sets standards for building construction of HUD-funded projects. Department of Defense is concerned with military-related noise, especially airports. The Federal Aviation Administration is also concerned with aircraft noise. The Bureau of Motor Carrier Safety deals with noise in the interstate trucking industry, and the Federal Highway Administration monitors noise associated with highway construction. These regulations will have only a minimal affect on the construction of a geothermal facility, with OSHA, perhaps, playing the most important role.

The New Mexico Heritage Program of the Natural Resources Department administers both the state's Endangered Species Act and the Federal Rare and Endangered Species Act and ensuing U.S. Fish and Wildlife Service regulations. Developers, although not required to secure a license in this regulatory area, do need to be aware that these regulations are being met. Other special regulations appear in the Migratory Waterfowl and Song Bird Acts. The U.S. Forest Service and the Bureau of Land Management have established Research Natural Area categories for some biotic units that have been placed into special use categories to preserve their natural conditions. Other special legislation, like the Wild Rivers Act, set aside parcels of land from any commercial development.

\subsubsection{Environmental Improvement Division Special Permits}

If appropriate to the construction plans, the following EID permits must be obtained prior to construction and operation of waste disposal, drinking water and food service facilities: 1) operation of a septic tank or discharge to community waste system, 2) operation of a public drinking water system; and 3) food service operation. Many geothermal facilities will require none of these.

\subsubsection{Päthway for Construction and Implementation for a Geothermal Facility in New Mexico}

Figure 16 shows the time line and events chart of institutional procedures for construction of a geothermal facility in New Mexico under state and local regulations and of the EIS process.

In general, the EIS process requires up to 12 months for lead agency review, another 6-12 months for the preparation of a draft EIS (by a designated federal entity), a public comment period of 2-12 months, a period for the resolution of public comments, the preparation of the final EIS document, and the release of the document and subsequent waiting period for final comments. When this process is 
CUMULATIVE TIME FOR FEDERAL EIS PREPARATION (where required)

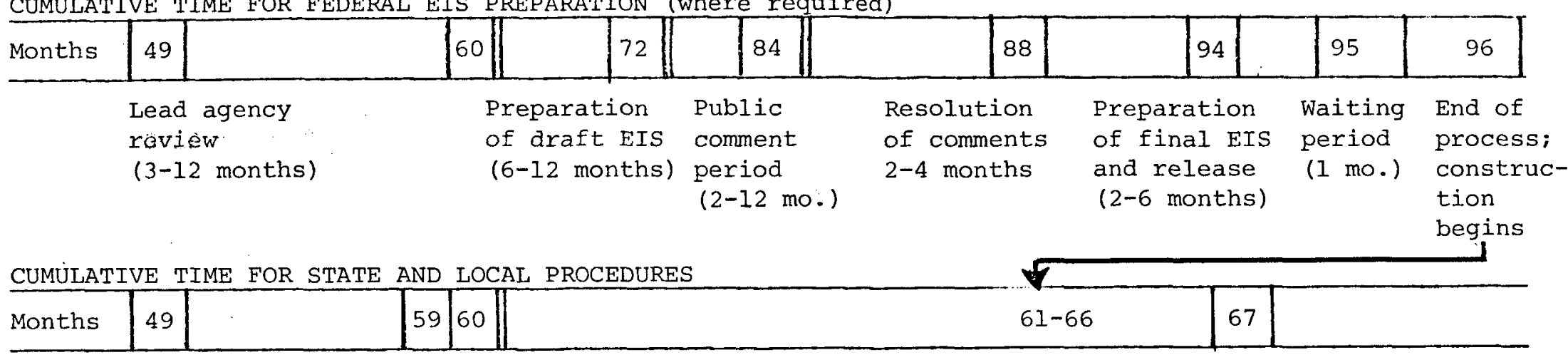

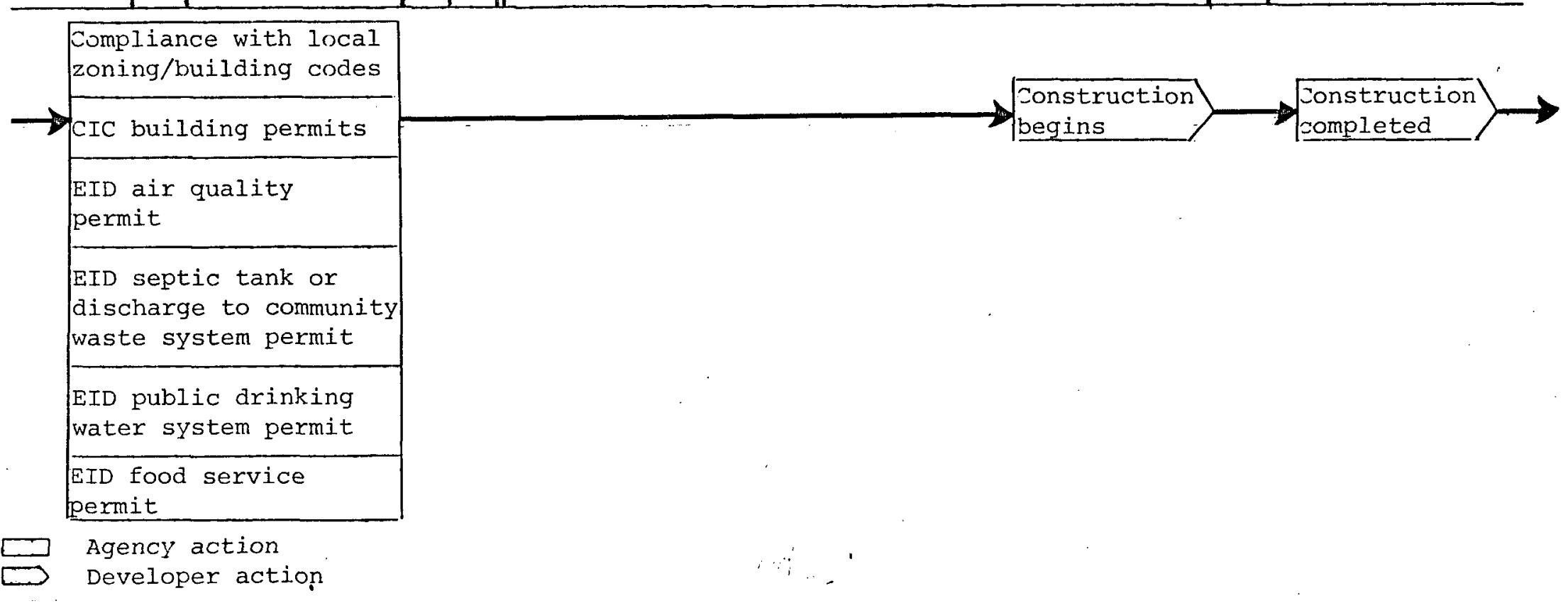

Figure 16. Time line and events chart (adapted from Hannah et a1.,1979) of institutional procedures for construction and implementation for geothermal facility in New Mexico under state and local regulations and of the EIS process. 
completed, construction may begin. Public hearings may be held during both the preparation of the draft EIS period and the period for public comment.

If the preparation of an EIS is not required for the construction of the geothermal facility, the time line may be significantly shorter for meeting the requirements of the state and local procedures. The final steps necessary prior to the construction of the facility are the obtaining of a variety of state and local permits. The three primary permits are those associated with meeting local zoning regulations or building codes, the Construction Industries Commission building permit and an EID air quality permit. EID septic or sewage discharge permits, a permit for the establishment of a public drinking water system and one for the operation of a food service apply only if the facility plans call for these systems.

\subsection{Operations Phase}

The final phase of geothermal commercialization activity is that of operating the now existing facility. In this phase, all previous regulations that affect the daily operations of the facility remain in effect.

\subsubsection{Hazardous Waste Regulations}

The EID would be required to issue a permit for the disposal of hazardous wastes, since hazardous waste regulations apply to the transportation and disposal of those materials deemed hazardous substances by regulation. This waste must be disposed of only at permitted waste disposal sites, as approved by the EID. The removal and disposal of solids built up from a geothermal operation, which contained highly toxic concentrations of trace elements, would qualify for this regulation (Hannah et al., 1979).

\subsubsection{On-Going Record Keeping and Reporting Requirements}

\subsubsection{State and Local Requirements}

As reported in the previous three sections, many state agencies have some type of continuing responsibility to the operation of a geothermal facility. Each agency, by virture of it's legislative charter, continues to monitor the operation of a geothermal facility in terms of state land leasing, functioning of wells and groundwater discharges, water rights and water usage, utility rate hearings and fee structures, taxation of income and collection of gross receipts taxes, air and water quality standards, and the general operation of business. In the process of carrying out these on-going responsibilities, environmental impact monitoring data is collected

over time. No agency, however, has a legislative responsibility to 
examine, after a period of extended facility operation, the cumulative effects of this operation on the environmental quality, or the comparative effects over time of the operation of similar facilities with other types of energy consumption.

\subsubsection{Federal Requirements}

The Environmental Protection Agency administers and enforces the Resource Conservation and Recovery Act (RCRA) in New Mexico. State and federal solid waste regulations would probably come into play only during the operation phase of some geothermal projects (Hannah et al., 1979).

\subsubsection{Pathway for Operation of a Geothermal Facility in New Mexico}

Figure 17 presents a time line and events chart of both the institutional procedures for operation of a geothermal facility in New Mexico and the federal environmental monitoring that is mainly executed by the complementary state agencies.

If the geothermal facility will accumulate solid waste with highly toxic substances, the EID permit for disposal of hazardous waste must be secured by the developer. After the plant begins operation, the daily requirements of on-going environmental responsibility come into play. These data provide a measure of environmental quality in the facility over time, even after the completion of an EIS, if required, and all other permitting responsibilities. 
CUMULATIVE TTME FOR FEDERAL ENVIRONMENTAL MONITORING ACTIVITIES

\begin{tabular}{ll|l}
\hline Months 97 & 98 & CONTINUOUS
\end{tabular}

EIS complete

Federal monitoring begins

CUMULATIVE TIME FOR STATE AND LOCAL PROCEDURES

$\begin{array}{ll}\text { Months } & 68 \\ & \text { CONTINUOUS }\end{array}$

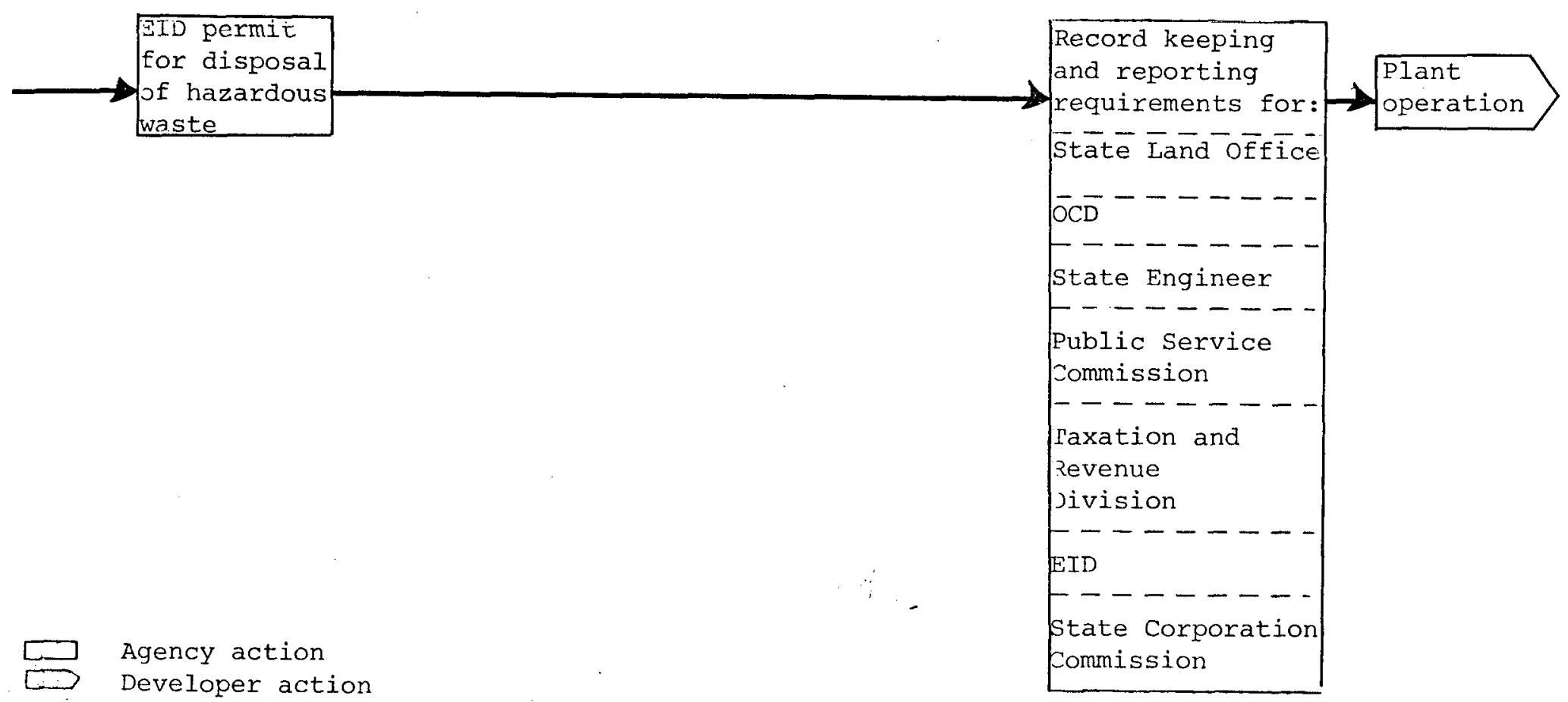

Figure 17. Time line and évents chart (adapted from Hannah et a1.,1979) of institutional procedures for operation of a geothermal facility in New Mexico under state and local regulations and federal environmental monitoring. 


\subsection{AVAILABLE INFORMATION FOR ASSESSING ENVIRONMENTAL IMPACTS ASSOCIATED WITH GEOTHERMAL DEVELOPMENT}

The six categories (Geophysical, Water, Air, Noise, Biota, and Socioeconomics) within this section were selected on the basis of their common appearance in Environmental Assessments and Environmental Impact Statements associated with geothermal energy projects. These categories were, in the opinion of the authors, the areas most likely to be impacted by geothermal development in New Mexico.

\subsection{Geophysical Data}

In the case of the geophysical data presented, a clear distinction must be made between quantifiable descriptors used in resource exploration and such resource descriptors used in measuring potential environmental effects due to project development (Marlin, pers. comm., 1979). Studies of thermal waters, heat flow, sedimentary basins, volcanic rock, volcanic activity, and faulting structures are all utilized in finding and evaluating geothermal resource areas. Possible effects associated with development of geothermal resources include seismic activity, subsidence and soil modification. These effects are considered due to their potential for causing structural damage to the physical aspects of development or the environment.

\subsubsection{Description and Measurement}

Sections 5.1.1.1 through 5.1.1.5 present a small-scale summary of research data obtained through a number of funding sources (the National Science Foundation, the United States Geological Survey, the Department of Energy, the New Mexico Research and Development Program and the efforts of over 20 reseachers of three New Mexico Universities). Data in these sections have been compiled into a common set under the State of New Mexico/Department of Energy, State Coupled Low Temperature Resource Assessment Program for future presentation in a state-specific 1:500,000 scale map series currently being assembled by NOAA for DOE and the State of New Mexico... The NOAA maps and associated reference documents list will be available from NOAA and/or the NMEI/NMSU in 1980.

\subsubsection{Distribution of Thermal Waters}

The logs of wells drilled for water, oil and natural gas in New Mexico provide data useful in the location of geothermal resource areas. Figure 18 shows the distribution of water, oil and natural gas wells with abnormally high bottom hole temperatures. This data is collected by the Oil and Gas Division of the Energy and Minerals Department in the process of drillers complying with state drilling regulations. Figure 19 shows the distribution of thermal wells and springs in relation to the identified geothermal sites in New Mexico indicating the range of in situ temperatures at these sites. Since none of these wells were 


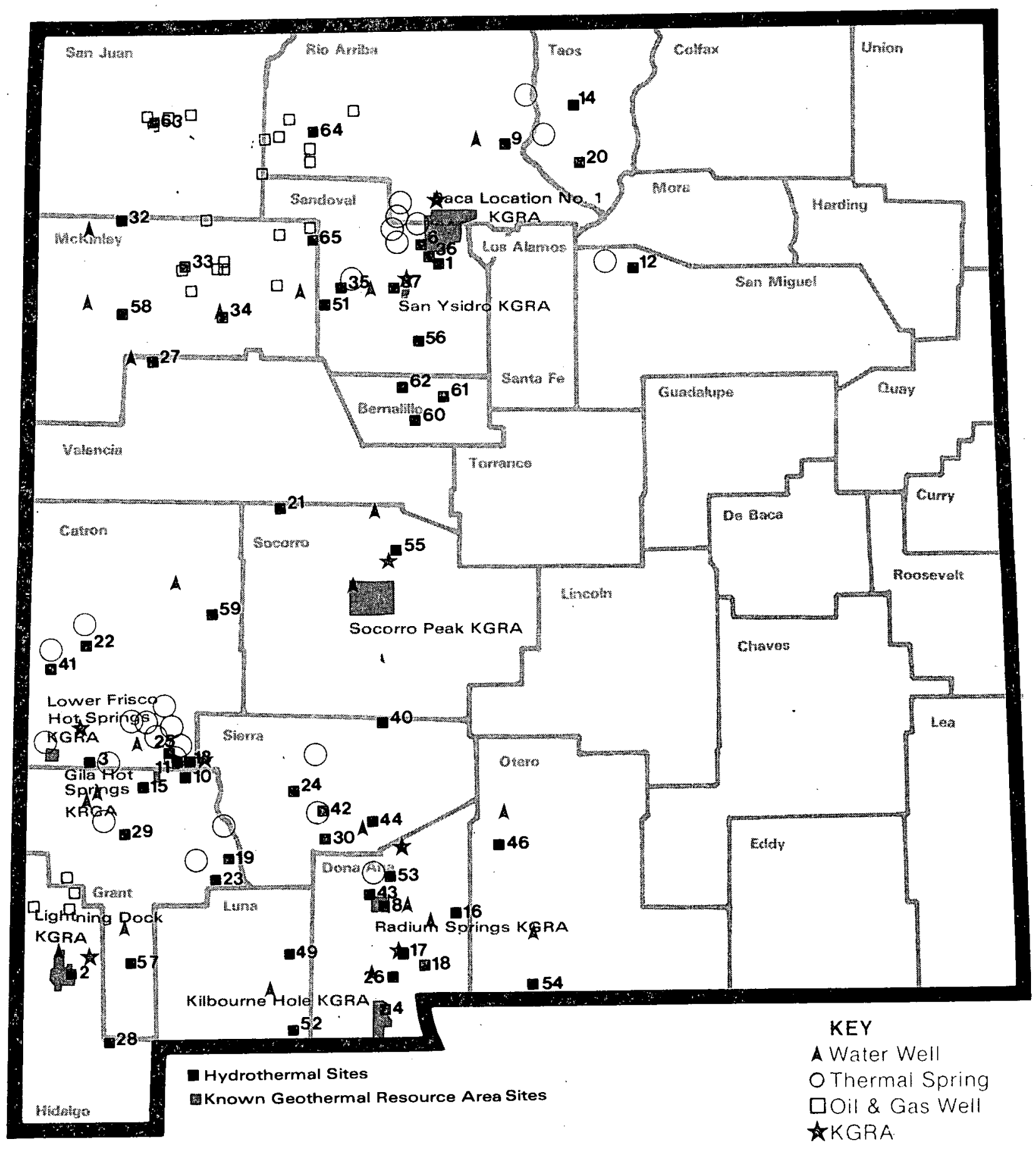

Figure 18. Distribution of water, oil and gas wells having abnormally high bottom hole temperatures in relation to geothermal sites in New Mexico (Chaturvedi, 1979b). 
drilled for the purpose of identifying or quantifying specific geothermal resource areas, they serve only as indicators of geothermal locations and may not be located in the prime portions of the geothermal resource areas.

\subsubsection{Heat F1ow Measurements}

Summarizing the data of four researchers from the New Mexico Institute of Mining and Technology and New Mexico State University, Figure 20 presents heat flow contours in relation to geothermal sites in New Mexico.

\section{1 .1 .3 Deep Sedimentary Basins}

A number of deep sedimentary basins have been mapped within the state. These data are presented in Figure 21.

\subsubsection{4, Quaternary Volcanic Rocks, Volcanic Centers, Quaternary and Other Tertiary Faults}

A sumnary of research data showing the location of late Quaternary volcanic rocks and major volcanic centers and the location of Quaternary and other Tertiary faults is presented in Figure 22.

\section{1 .1 .5 Seismicity}

In 1962, a regional seismic monitoring network was established in New Mexico. Prior to the establishment of this network, seismic activity was not measured precisely, but was recorded only as "felt" earthquakes (Figure 23). Data from this period is probably biased in terms of where people were located at the time of the seismic activity and how "strong" a tremor they thought they had felt.

Seismic activity has been monitored as precise data since 1962 (Figures 24 and 25). This data, however, may be biased by the location of the monitoring stations.

\section{1 .1 .6 Subsidence}

The Environmental Overview staff has been unable to locate any subsidence baseline data in New Mexico.

\section{1 .1 .7 Soils}

Soil associations and classification data is available for every New Mexico county except Luna, Mora, parts of Sandoval and Socorro. This data has been published by either the Soil Conservation Service and Forest Service in cooperation with the New Mexico Agricultural 


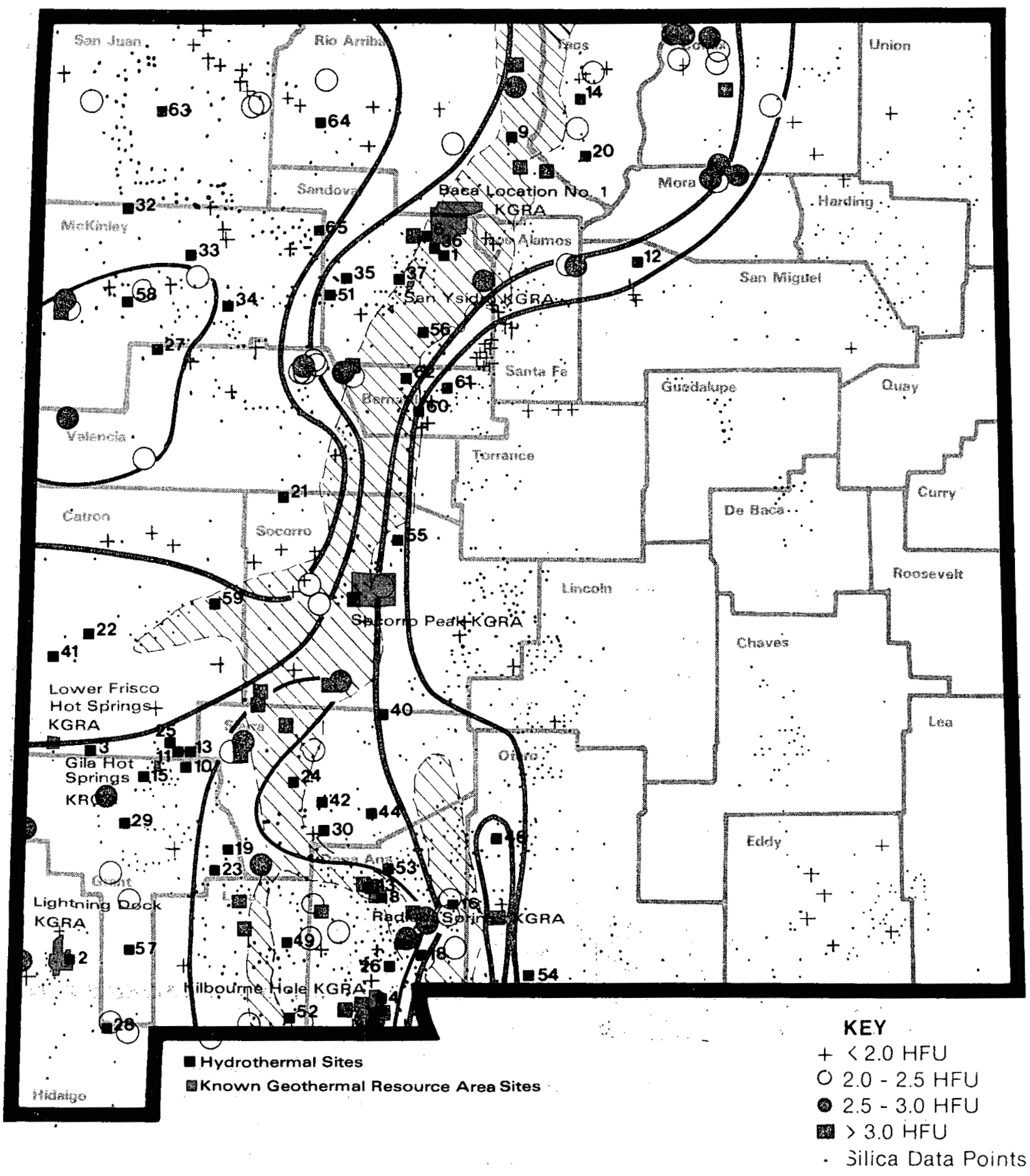

Figure 20. Heat flow contoùr map in relation to geothermal sites in New Mexico (Morgan et a1., 1979). 

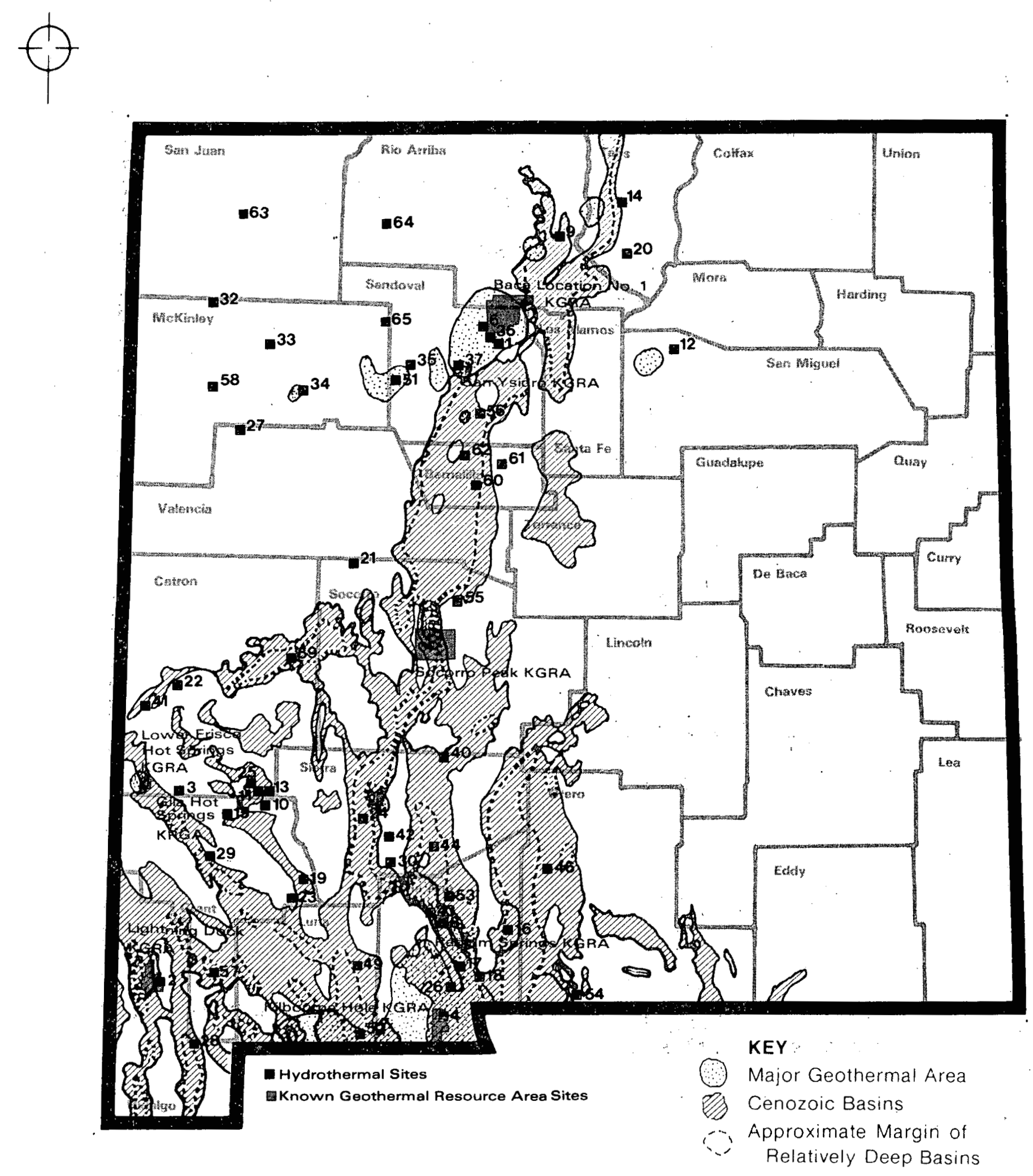

Figure 21. Deep sedimentarỳ basins relative to major geothermal sites in New Mexico (Callender and Swanberg, 1979). 


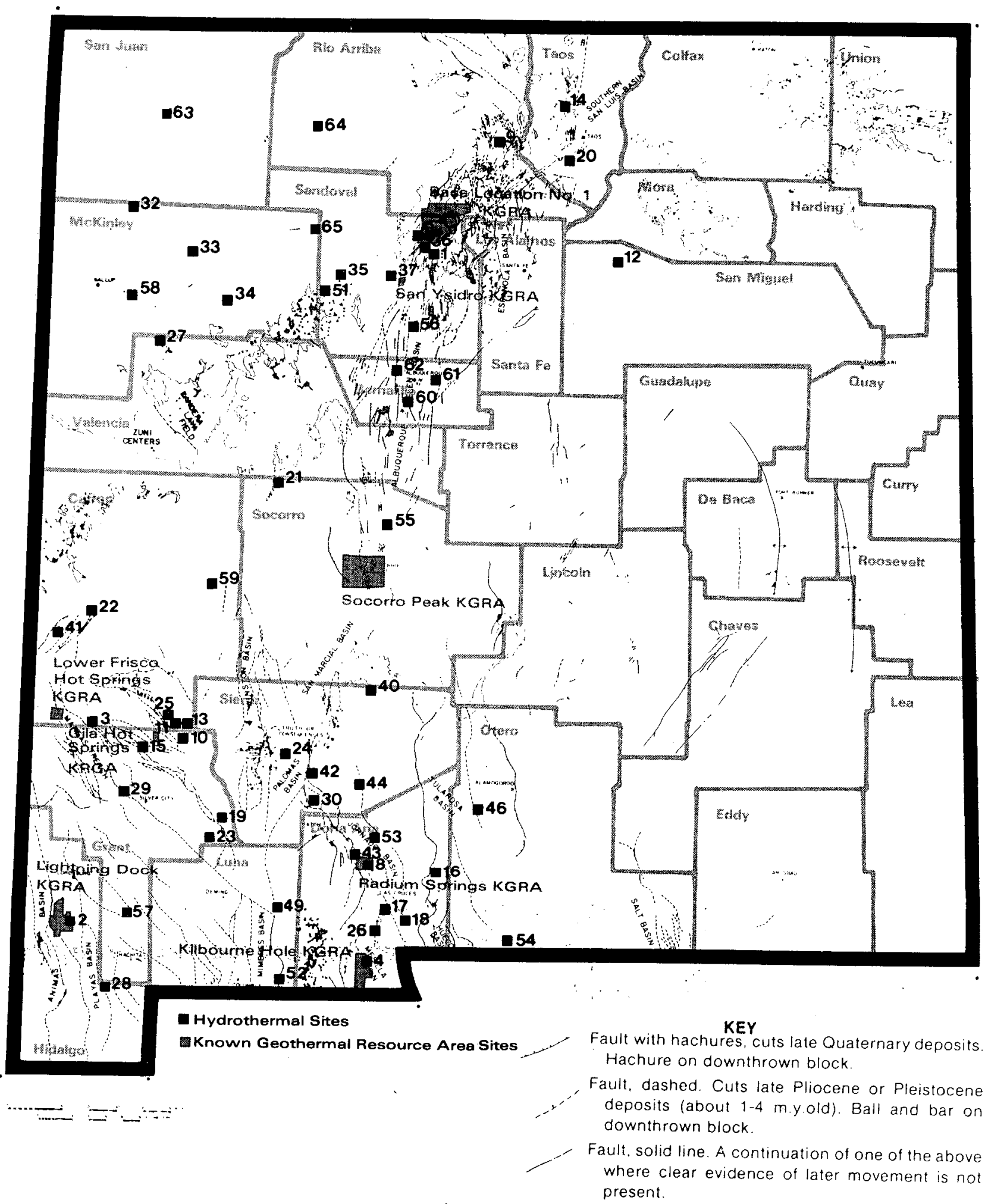
Hachure on downthrown block.

Fault, dashed. Cuts late Pliocene or Pleistocene deposits (about 1-4 m.y.old). Ball and bar on downthrown block.

- Fault, solid line. A continuation of one of the above where clear evidence of later movement is not present.

All faults dotted where concealed or covered. 


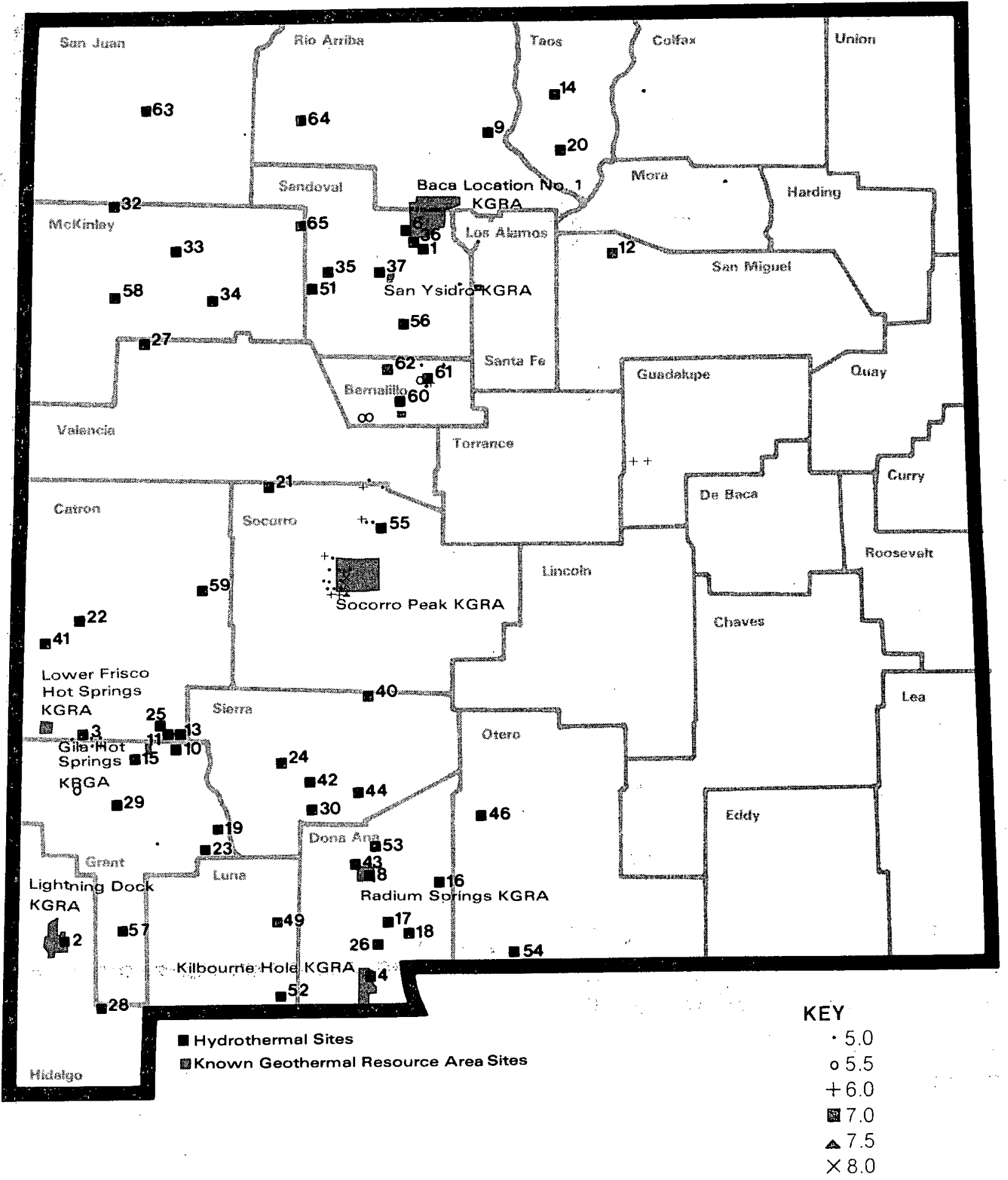

Figure 23. Seismic activity ("felt earthquakes") prior to the installation of a regional seismic monitoring network in 1962 in relation to geothermal sites in New Mexico (Sanford, 1979b). 


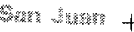

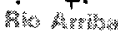

64

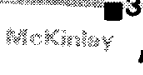

$32 . \sqrt{1}+0^{9}$ $9^{9} 0$ $-20$

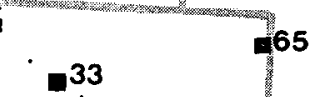

$\square 8$

133

165

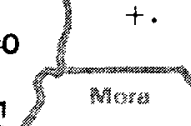

$+$
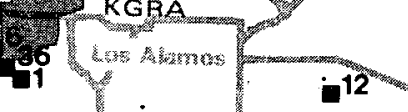

San Ysidro KGRA

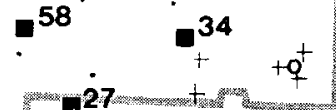

5

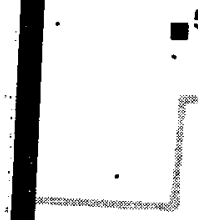

Wastom
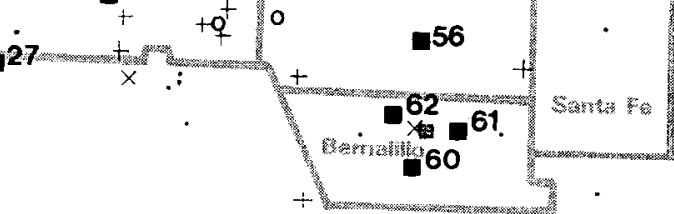

cutury

$0^{41}$

Lower Frisco

Hot Springs

KGRA

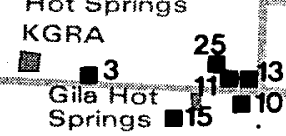
KRGA
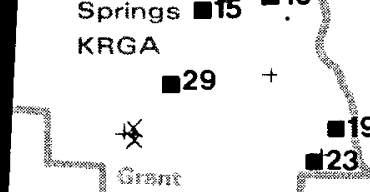

LGhtn
KGRA

ning 00

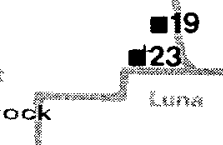

B

5

55

Kilbourrie Hold KGRA.

Torganses +
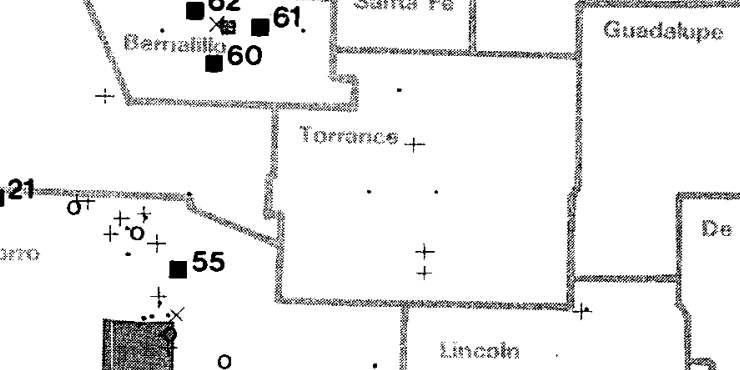

consy

ro Peak KGRA.
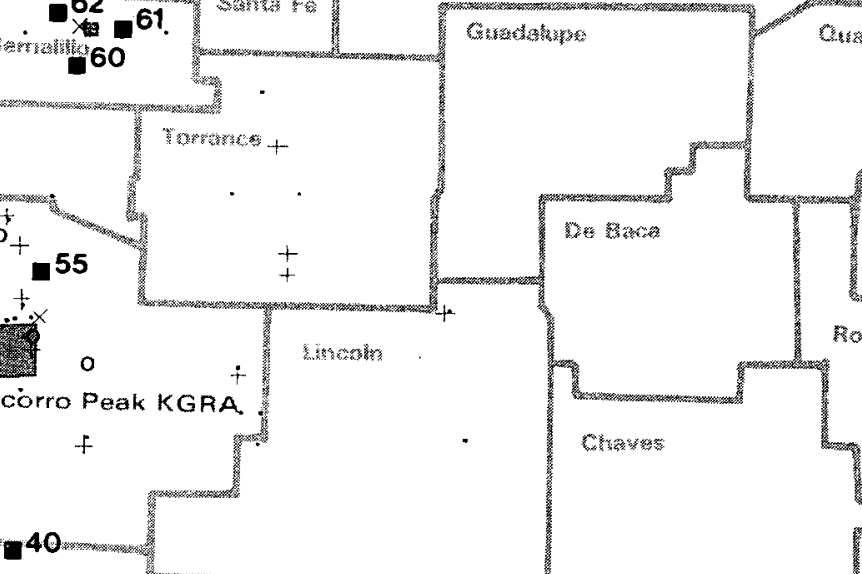

Preso
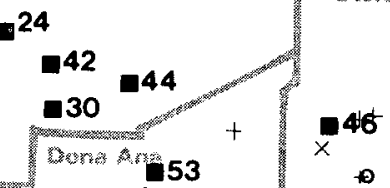

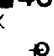
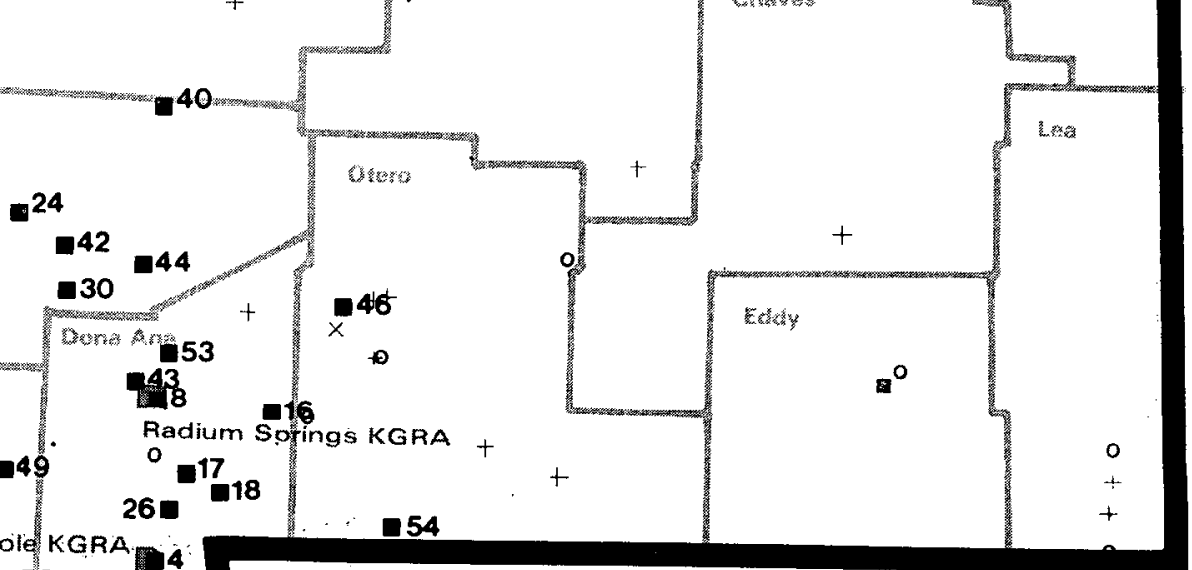

Hydrothermal Sites

Known Geothermal Resource Area Sites

KEY

A $>4$

$3.5-3.9$

$\times 3.0-3.4$

$0.2 .5-2.9$

$+2.0-2.4$

- $1.5-1.9$

Figure 24. Recorded seismic activity between 1962 and 1967 in relation to geothermal sites in New Mexico (Sanford, 1979b). 


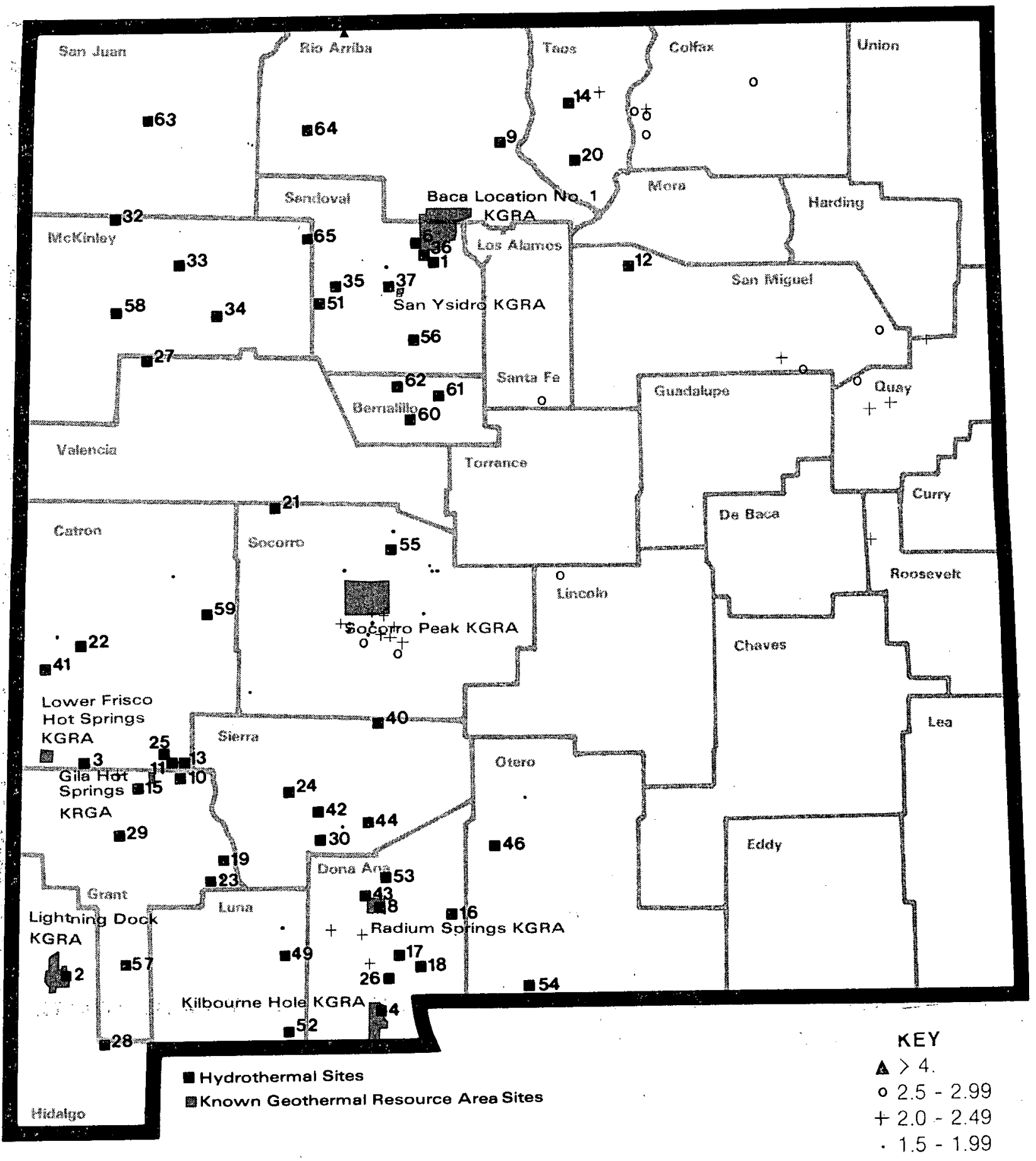

Figure 25. Recorded seismic activity between 1978 and 1977 in relation to geothermal sites in New Mexico (Sanford, 1979h). 
Experiment Station or by the Agricultural Experiment Station itself.

The Soil Conservation Service and Forest Service reports are comprehensive in nature, including a general soil map, a description of the soil, use and management of the soil, formation and classification of the soils, and the general nature of a county. Mapping for these reports were executed at two intensities, high and low. The high intensity areas were mapped in considerable detail. Low intensity surveys, mainly rangeland, has less detailed mapping. The county reports indicate the level of intensity used for any parcel of land within the county. SCS reports are available for the following counties and areas (see Figure 26): Bernalillo County, Bluewater Area, Cabezon Area, Curry County, Eddy Area, Hidalgo County, Harding County, Lea County, Mescalero-Apache Area, Quay County (North and Southwest Areas), Roosevelt County, Santa Fe County, Torrance County and the Zuni Mountain Area.

The New Mexico Agricultural Experiment Station reports are less comprehensive, suited to appraising land for irrigation, and to a lesser extent, to preliminary planning for forestry, range, urban, engineering, recreation and wildlife uses. AES reports are available for the following counties (see Figure 27): Catron, Chaves, Colfax, Curry, DeBaca, Dona Ana, Eddy, Grant, Guadaupe, Hidalgo, Lea, Lincoln, Los Alamos, McKinley, Otero, Quay, Rio Arriba, Roosevelt, Sandoval, San Juan, San Miguel, Santa Fe, Sierra, Taos, Torrance, Union and Valenica.

\subsubsection{Current Monitoring Activities}

5.1.2.1 Thermal Waters, lleat Flow, Sedimentary Basins, Quaternary

Thermal waters data will continue to be collected on new well sites through the on-going regulatory activities of the Oil and Gas Division of the Energy and Minerals Department and the State Engineer's Office. Through September 1980, at least, the State Coupled Low Temperature Geothermal Resource Assessment Program will provide additional data on these wells. "Heat flow data, basic geological data in potential geothermal sites and data on seismic activity in the state will also continue to be developed through the New Mexico Bureau of Mines and the faculties of the three major universites-The University of New Mexico, New Mexico Institute of Mining and Technology, and New Mexico State University. Much of this data, however, will not be specific to an individual geothermal resource area. Specific geophysical data is available on the Baca 非 1 KGRA (Baca EIS, 1979) and some monitoring for geophysical changes stimulated by geothermal development, if any, will occur at this site.

\section{1 .2 .2 Subsidence}

There is no general program for monitoring subsidence activities that can yield either baseline data or data on changes over time in the public domain. 


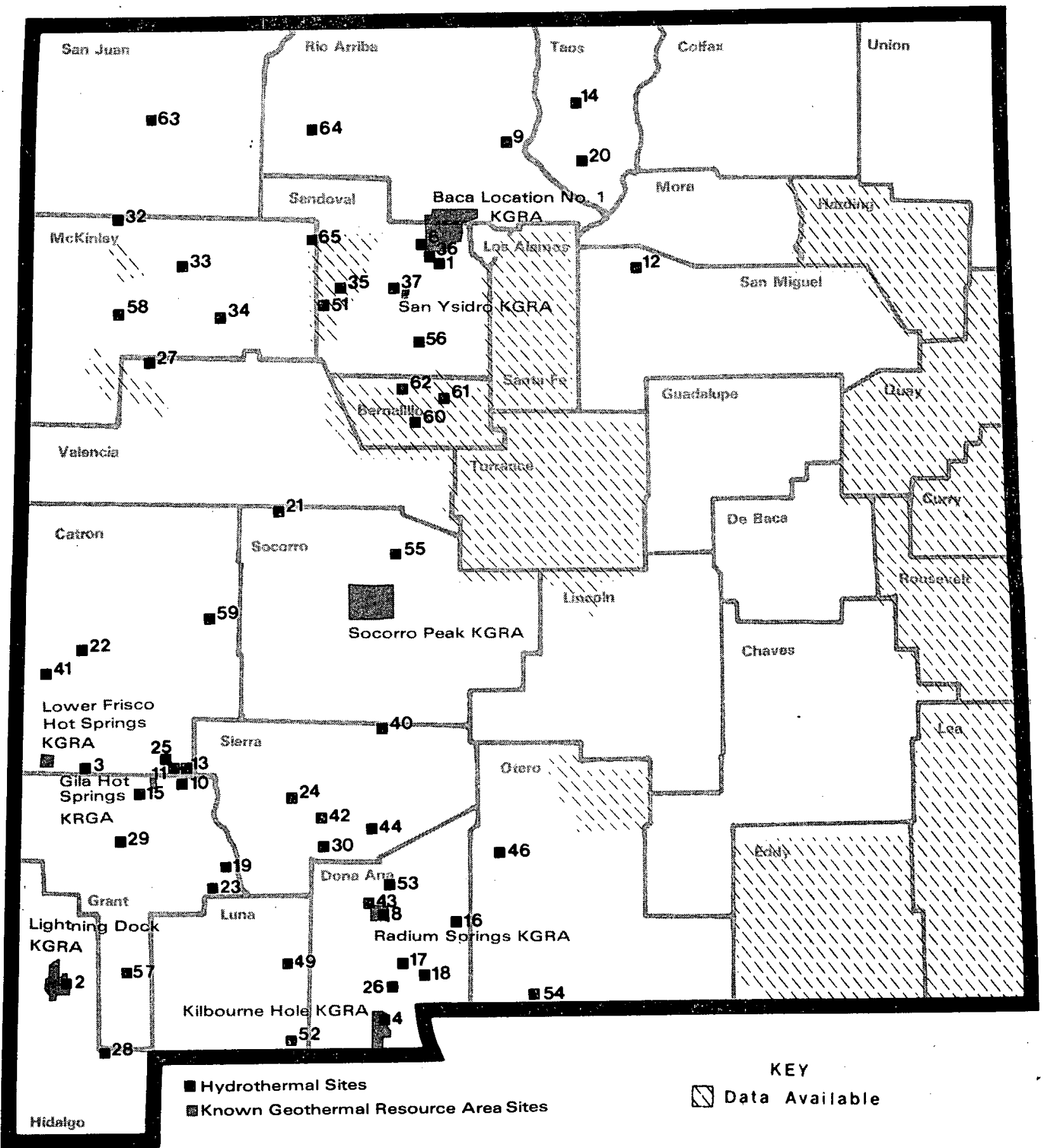

Figure 26. Availability of soil classification data from the Soil Conservation Service and Forest Service in relation to geothermal sites in New Mexico. 


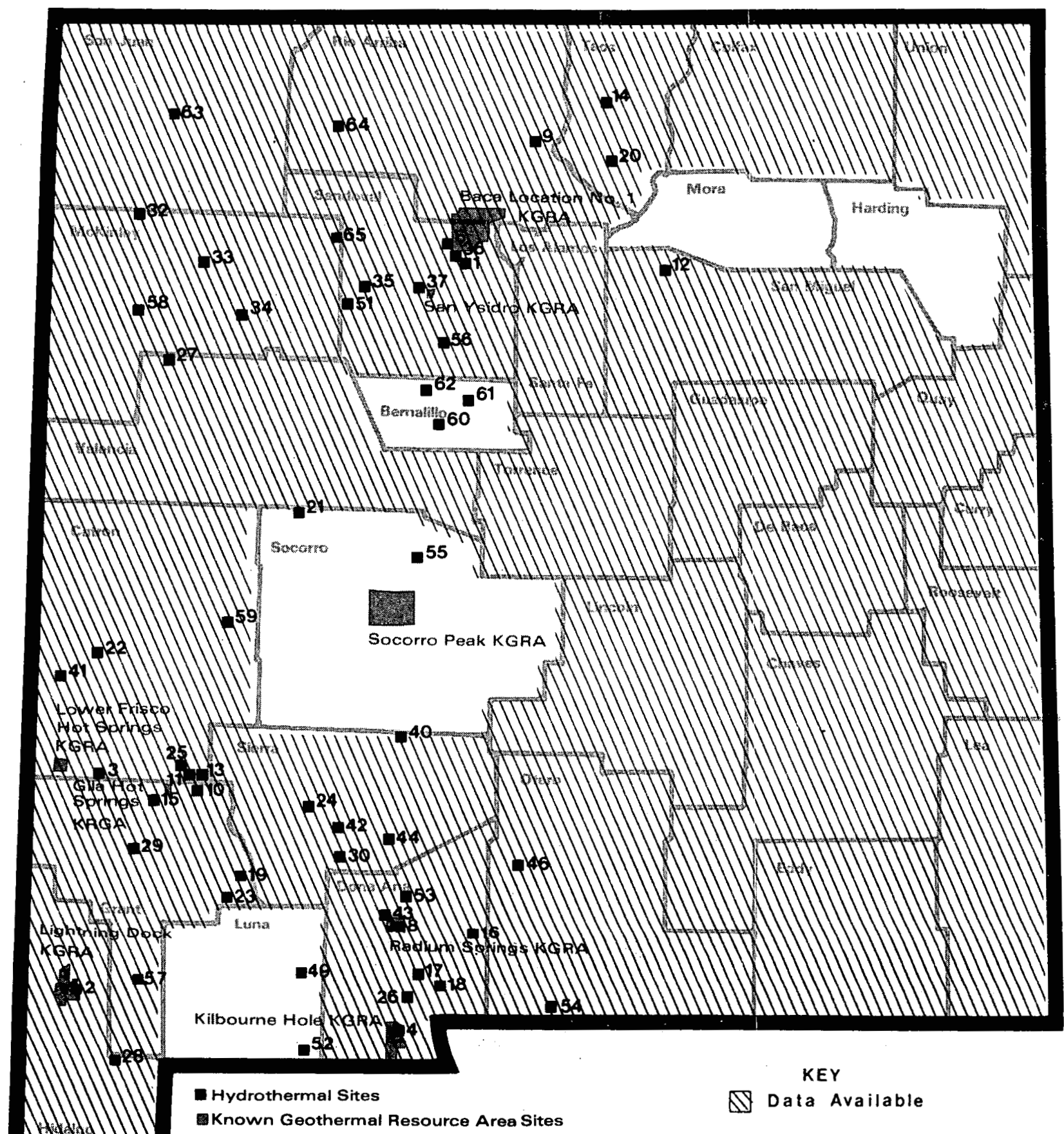

Figure 27. Availability of soil classification data from the New Mexico Agricultural Experiment Station in relation to geothermal sites in New Mexico. 


\section{1 .2 .3 Soils}

Continuing programs of the Soil Conservation Service, the Forest Service and the New Mexico Agricultural Experiment Station will provide additional data about soils and soils classification.

\subsubsection{Accuracy of Baseline Data}

Although the quality of geophysical data is excellent (with the exception of subsidence data), it is, for the most part, of a general nature. Data on thermal wells is specific to given wells, but the wells may not be at optimum locations within a geothermal resource area. Available data on heat flow, sedimentary basins, Quaternary structures and faults and seismicity are useful in locating potential geothermal areas, but the data is insufficient to determine well placements and potential environmental impacts. This is particularly true with seismic data which may be biased to the location of monitoring stations. One must obtain information through site-specific field work using test wells to determine the chemical composition, temperature and quantity of geothermal waters at the anticipated production well depth in order to determine the environmental impact of an individual geothermal application in a particular geothermal reservoir. This specific data is necessary to predict the impact on air and water quality, and would be collected in the process of exploration and development. 'If subsidence is assumed to be a potentially significant environmental issue, then baseline subsidence data collection and continuous monitoring are required for decision-making.

The soils data are by far the most complete. In areas of the state where only an Agricultural Experiment Station report is available, it may be necessary to carry out more detailed soil surveys on the specification locations which are involved in a new geothermal development. In areas of the state where a Soil Conservation Service survey has been completed, there is probably sufficient data available for determining optimum well and plant sites, roads and transportation corridors.

\subsection{Water Data}

The data and other information for this section is taken largely from four documents: New Mexico Water Resources Assessment. for Planning Purposes, (State of New Mexico, 1976); 1972 Water Resources Data for New Mexico, Part 1, Surface Water Records (USGS, 1974); 1972 Water Resources Data for New Mexico, Part 2, Water Quality Records (USGS, 1975); and Geothermal Data from New Mexico Geothermal Waters (Swanberg, 1978b). These documents will be quoted freely.

New Mexico is a water-deficient area with respect to the availability of freshwater to maintain present irrigated agriculture and to meet other projected needs. Except for small quantities of available 
undeveloped surface water supplies in the Lower Colorado and Arkansas-White-Red River systems and the almost fully committed but not yet used supplies of the Upper Colorado Basin, the surface supply is fully appropriated and is being used beneficially within the terms of international treaties, interstate compacts, court decrees, and state laws.

New Mexico receives as precipitation, in the form of rain and snow, an estimated 85 million acre-feet of water each year from which about three million acre-feet is realized as runoff in streams. The remaining 82 million acre-feet returns to the atmosphere through evaporation and transpiration by vegetation or percolates into the earth as recharge to underground aquifers which do not discharge directly to streams in New Mexico. About one million acre-feet out of three million acre-feet of runoff is also lost to non-beneficial evapotranspiration.

New Mexico receives water from upstream states, mostly from Colorado via the San Juan River and the Rio Grande. Commitments to downstream states under existing interstate compacts and court decrees require apportionment of water to those states. When New Mexico has fully developed its surface water resources, within the allowances of interstate compacts and court decrees, river outflow will approximate river inflow and the state will be using about the amount of streamflow that it produces.

In addition to the surface water supplies, New Mexico is fortunate to possess large quantities of water in underground storage. The magnitude of this supply is estimated by the Geological Survey to be some 20 billion acre-feet, with about one-quarter being fresh or only slightly saline. It is estimated that about three billion acre-feet of freshwater and 1.4 billion acre-feet of slightly saline water would be recoverable.

In some areas of the state where groundwater of good quality can be economically obtained, development and use have been underway for several decades. The draft on the supply in many areas where significant development has occurred, exceeds recharge; consequently, groundwater levels are declining. There are no data on subsidence associated with this decline.

Generally, surface runoff and groundwater discharge from the high mountains are of excellent quality, due to the nature of the geologic formations present. Water originating from lower areas, frequently, is of a lesser quality, due to presence of more readily soluble minerals. As good quality water flows downstream it is subjected to degradation by use and co-mingling with other waters containing substantial quantities of dissolved solids acquired through natural processes and uses by man. 


\subsubsection{Description and Measurement}

\subsubsection{Genera1}

The State of New Mexico is divided topographically into five major surface-water drainage basins, as designated by the Water Resources Council. In addition, the Pecos River Basin is separated from the balance of the Rio Grande Basin since the drainages do not combine within New Mexico, thus defining a sixth basin.

Under authority of the groundwater code, the State Engineer assumes jurisdiction over the appropriation and use of groundwater in an area when boundaries are reasonably ascertainable and management control over the area is deemed necessary, and he so proclaims. As of March 1976, 25 such basins have been proclaimed or declared. These basins embrace more than $58 \%$ of the total state area. The location and names of the basins are shown on Figure 28. Further water development in a declared underground water basin is subject to a State Engineer's ruling that unappropriated water is available and new appropriations will not impair existing rights.

Groundwater depletions for all purposes increased from less than half a million acre-feet in 1940 to more than a million acre-feet in 1970. Not all groundwater is physically and economically extractable. Extensive studies will be required to determine the quantity and quality of all groundwater supplies. The areas that have been studied, and the reports prepared thereon are shown in Figure 29. A bibliography of these reports is available in the New Mexico State Engineers Office.

\section{2 .1 .2 Quantity of Water}

One of the most apparent features of New Mexico's water supply is the unevenness of its distribution.

Long-term streamflow records show that New Mexico receives an annual water supply of about 5.7 million acre-feet. Precipitation within the state accounts for about 3.3 million acre-feet; and about 2.4 million acre-feet are received as streamflow from other states, mostly from Colorado via the San Juan River and the Rio Grande. New Mexico depletes about 2.3 million acre-feet of surface water annually, and about 3.4 million acre-feet are discharged each year to downstream states.

Water uses depending on surface water are assumed to have essentially a full supply in 1970. Therefore, 1970 depletions from surface supplies plus small amounts yet undeveloped in the Lower Colorado and Arkansas-White-Red Basins, and the committed but yet unused supplies from the Upper Colorado Basin are assumed to make up the surface water supply currently available for use in the state under existing compacts, treaties, and court decrees. 


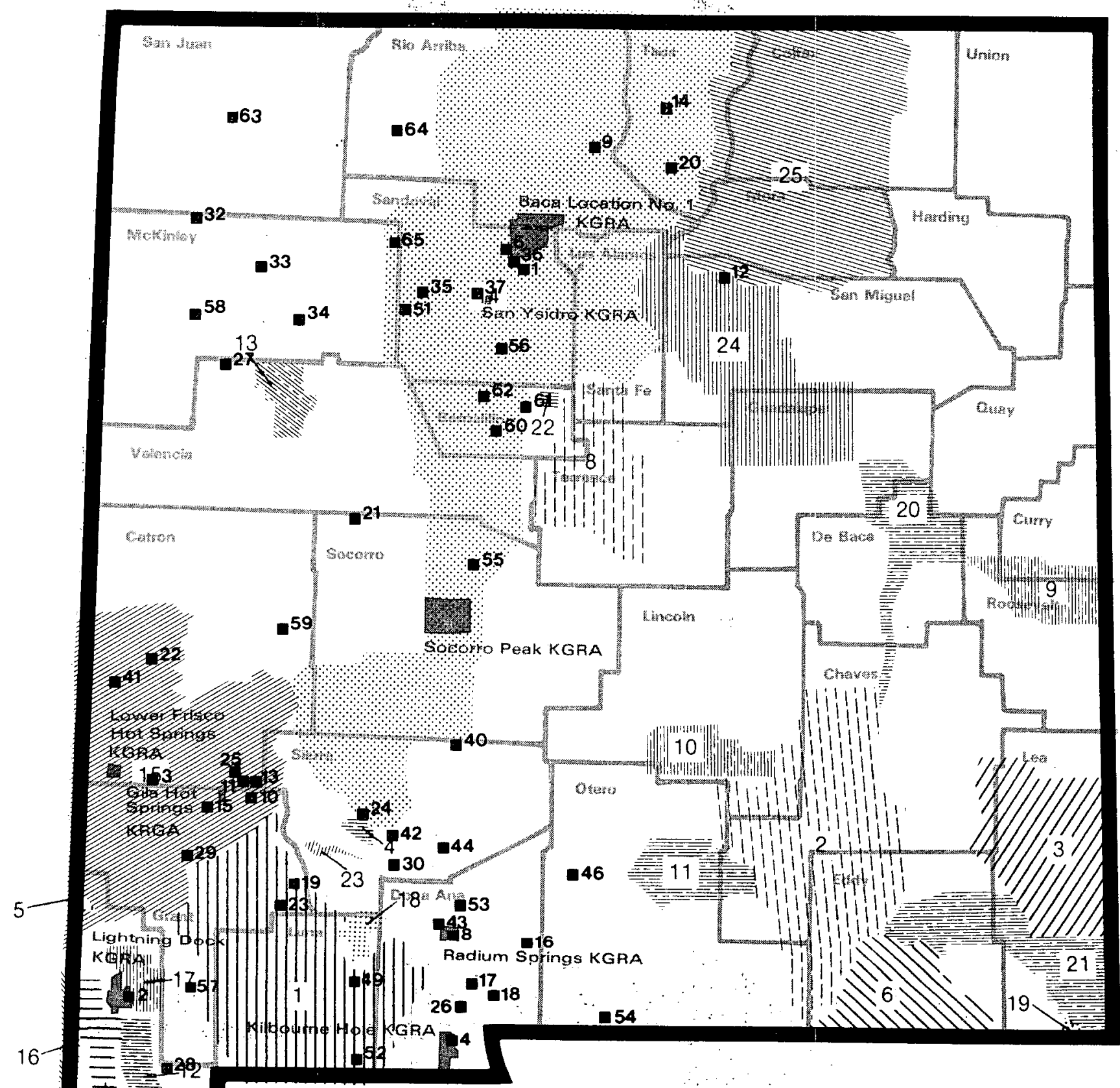

- Hydrothermat Sites

Known Geothermal Resource Area Sites

\section{Underground Water Basins}
1. Mimbres Valley
2. Roswell Artesian
3. Lea County
4. Hot Springs
5. Virden Valley
6. Carlsbad

7. Animas Valley
8. Estancia
9. Portales
10. Hondo
11. Penasco
12. Playas Valley

7. Animas Valley

9. Portales

11. Penasco

12. Playas Valley
13. Bluewater

14. Rio Grande

15. Gila-San Francisco

16. San Simon

17. Lordsburg Valley

18. Nutt-Hockett
19. Jal

20. Fort Sumner

21. Capitan

22. Sandia

23. Las Animas Creek

24. Upper Pecos

25. Canadian River

Figure 28. Twenty-five declared underground water basins in New Mexico (State of New Mexico, 1976). 


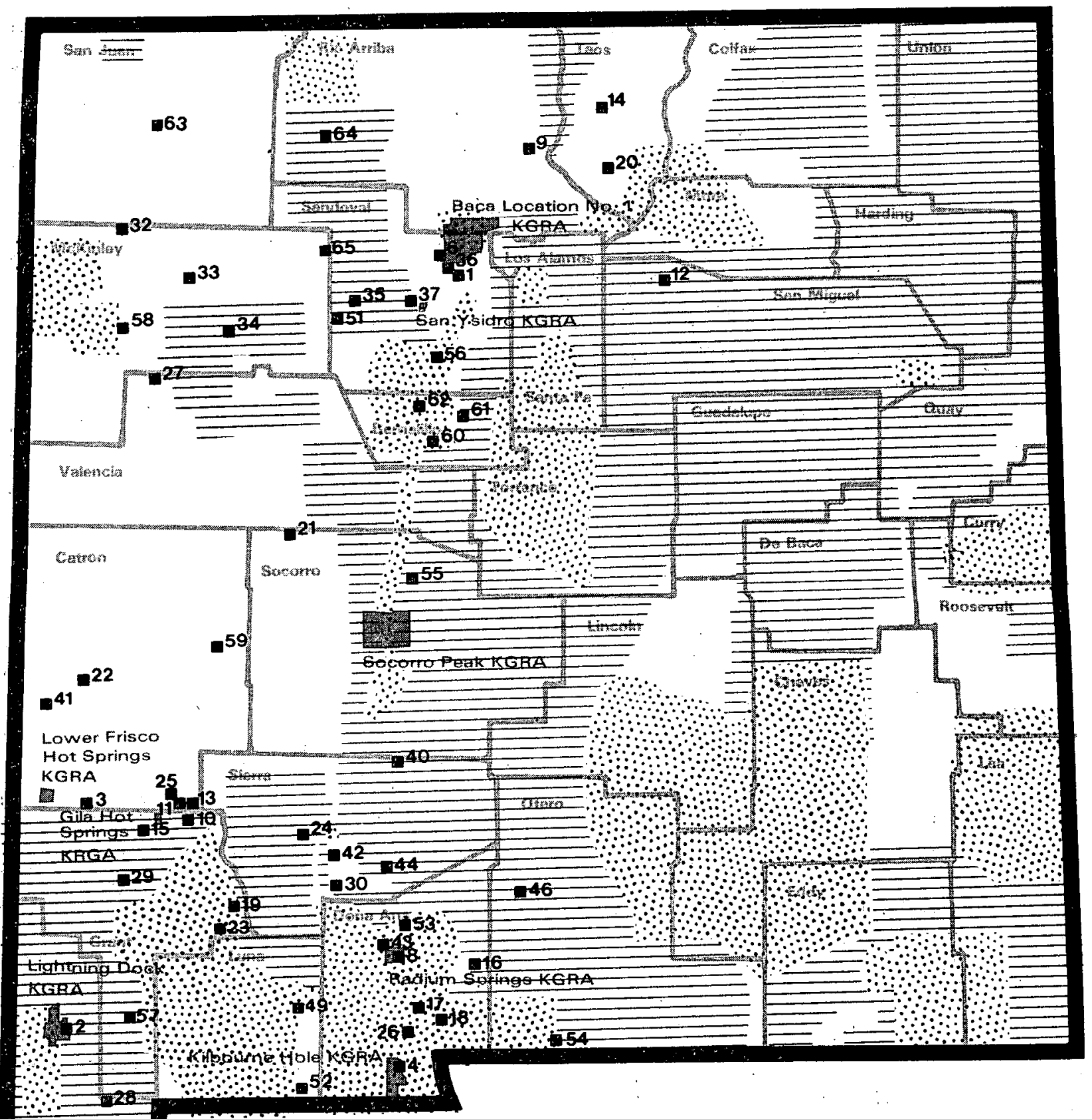

Hydrothermal Sites

Known Geothermal Resource Area Sites

KEY

. QUANTITATIVE

$\exists$ QUALITATIVE

$\square$ RECONNAISSANCE

Figure 29. Locations of groundwater studies in 1973, divided into quantitative, qualitative and reconnoissance work (State of New Mexico, 1976). 
Surface water surpluses in 1970 include small amounts of undeveloped water in the Little colorado and Arkansas River systems and a considerable amount of the water in the San Juan River, which is almost entirely allocated to authorized projects. The San Juan-Chama Project will divert an average of 110,000 acre-feet of water each year from the Upper Colorado River Basin into the Rio Grande Basin. A large part of the supply is being diverted at the present time. Initial delivery of water was made in March 1971. Other authorized projects are the Navajo Indian Irrigation, Animas-La Plata, and Hammond Projects.

Figure 30 indicates graphically the average discharge of most of the streams with appreciable discharge. This map also shows the volume of annual runoff during the period 1951-1970. It should be noted that, although lines of equal runoff have been extended to all parts of the state, average runoff is poorly defined in areas where streamflow data are scarce or unavailable. The average annual discharge in acre-feet, is the mean of the annual discharges published during the 1951-1970 water-year period. The average annual discharge, in inches, indicates the relative productivity of each contributing drainage basin.

In most of the major drainage basins of the state, a close relationship between groundwater and surface water exists; a change in regime of either will generally affect the other. However, the effect of pumping on the surface supply depends on how near a well is to the river, the time since pumping started, and the aquifer coefficients. At the present time, most stream-connected groundwater aquifers are administered by the State Engineer. The total water resource is therefore conjunctively managed to provide optimum use.

In addition to flow in rivers, about 4.4 billion acre-feet of recoverable fresh and slightly saline groundwater is estimated to be present in underground storage. About three billion acre-feet of this water in storage is fresh and may be used without treatment for many purposes.

Groundwater is heavily pumped in intermontane basins along the Rio Grande, in the Roswell and Carlsbad areas of the Pecos Valley, and in the High Plains area of eastern New Mexico. In many developed areas groundwater is being mined, and as a result there is a decline in water table levels.

There are large quantities of Eresh groundwater available for development in several of the drainage basins. The thickest known aquifer is in the unconsolidated sand and gravel within the valley of the Rio Grande. However, in most cases these groundwater supplies are stream-connected; their development would affect surface supply. In some areas of the state, it is difficult to develop suitable supplies of fresh groundwater since the aquifers are of low transmissivity and yield little water to wells.

Saline groundwater occurs throughout the state--generally at greater depths than freshwater. Salinity commonly increases with depth beneath the land surface. 

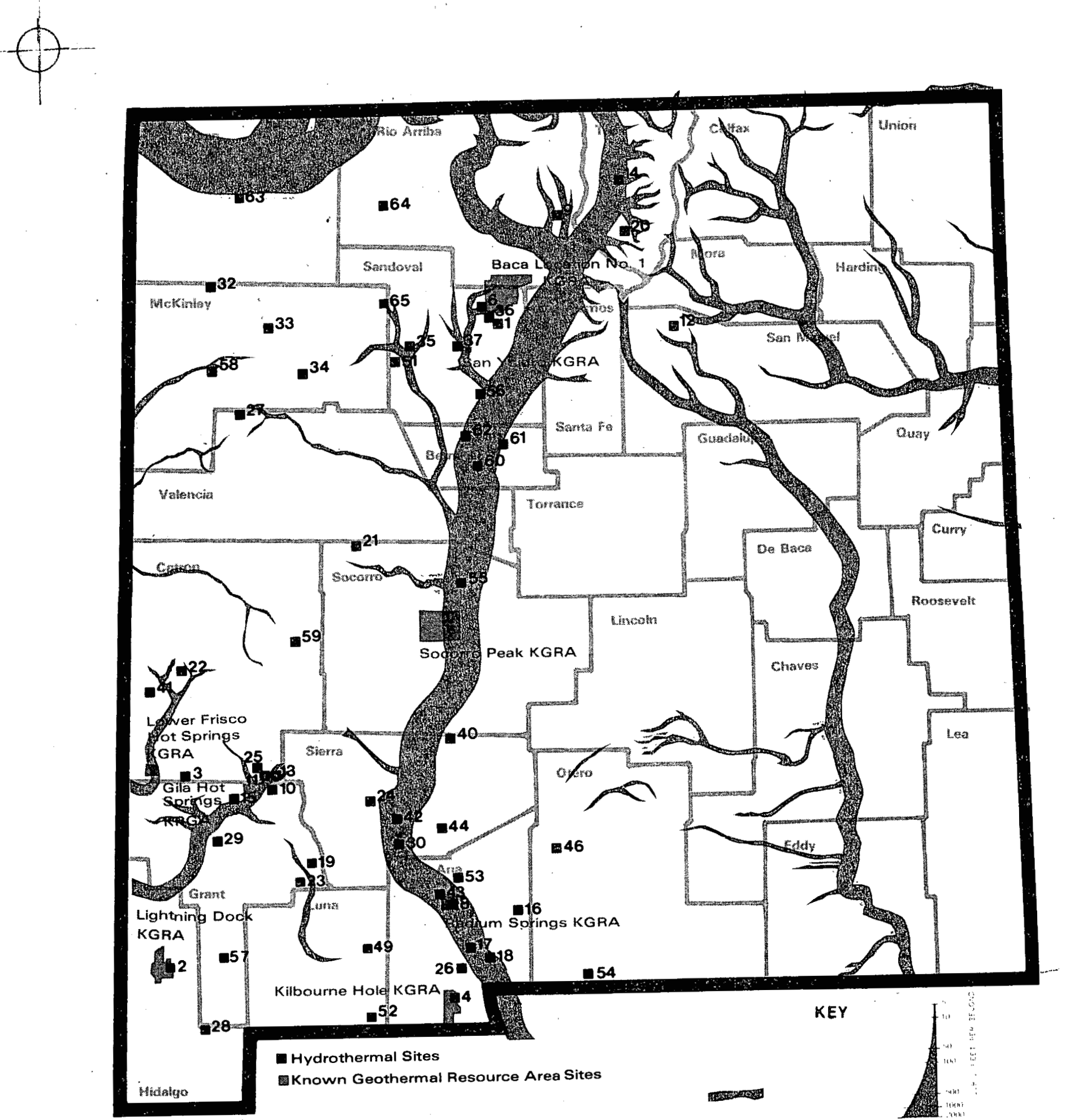

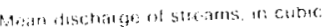

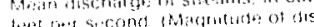

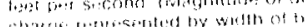

Descharge in cubce teer per second. equats fwith of bat. wh the Sine siale.

Figure 30. Mean discharge of selected reaches of streams, in cubic feet per second and mean annual runoff, in inches in New Mexico, 1951-1970 (State of New Mexico, 1976). 
As demands for water increase, the shallower freshwater aquifers in most areas will not be able to supply the demand, and it may become necessary to utilize saline water. As desalination processes become more advanced, and relatively more economical, saline groundwater will be recognized as a valuable part of the total water resources in New Mexico.

\section{$5.2 \cdot 1.3$ Quality of Water}

\subsection{Surface and Groundwaters}

Another characteristic of the New Mexico water supply is the wide variability in chemical quality found over the state. According to the New Mexico Water Quality Commission Report, existing stream quality ranges from nearly pristine in mountain streams to highly turbid and saline in the lower stream reaches. Most of these changes are attributable to natural causes and the normal degradation as a result of consumptive use. Throughout New Mexico, limited streamflow is available for dilution and assimilation of wastewater, increasing the need for waste water treatment, proper disinfection, and in some reaches removal of algal stimulants such as nitrogen and phosphorous. Groundwater also varies regionally in quality. In some areas of the state, groundwater which does not meet the quality prescribed by public health drinking water standards and National Academy of Science Criteria is used because it is the only water available. In accordance with Federal Water Pollution Act (Public Law 92-500), water quality standards designed to protect the existing quality of all perennial reaches of streams were adopted in August 1973.

Freshwater is defined as water that contains less than $1,000 \mathrm{mg} / 1$ of dissolved solids. However, this definition does not necessarily determine the suitability of such water for human consumption. The following standards and tolerances are generally accepted for water that is used for the various purposes described.

Slightly saline groundwater is used for drinking, irrigation, and industrial purposes in those parts of the state where water of a better quality is not available locally or is in short supply. Slightly saline water is defined as water containing from 1,000 to $3,000 \mathrm{mg} / 1$ of dissolved solids.

Water used for human consumption should not only be chemically and biologically safe but should also be free of undesirable physical properties such as color and taste. Listed below are a few of the recommended drinking water standards established by the U.S. Public Health Service in 1962 . 
Substance

Chloride (C1)

Sulfate $\left(\mathrm{SO}_{4}\right)$

Total dissolved solids (TDS)
Concentration (mg/1)

250

500

There have been no obvious detrimental effects on public health in areas where water supplies being used do not meet the above standards. Many other toxic substances affect water quality. Generally, information on these substances is available in appropriate publications. The recently enacted Federal Safe Drinking Water Act of 1974 (Public Law 93-523) may provide some additional safeguards for public drinking water.

It is not possible to set a definite maximum hardness standard for public water supplies because objections depend on what the consumer has become accustomed to and to economic considerations. Hardness of more than $300-500 \mathrm{mg} / 1$ of calcium carbonate $\left(\mathrm{CaCO}_{3}\right)$ is excessive for public water supply. Many consumers will ob ject to water harder, than $150 \mathrm{mg} / 1$. In other communities, the criterion for maximum hardness is considerably less than $150 \mathrm{mg} / 1$. A moderately hard water is sometimes defined as having hardness between 60 to $120 \mathrm{mg} / 1$.

Water consumed by livestock is subject to similar limitations as water consumed by humans, but higher concentrations of pollutants are permissible. The maximum concentration of total dissolved solids varies from about $2,800 \mathrm{mg} / 1$ for poultry to about $12,900 \mathrm{mg} / 1$ for sheep. Range cattle will drink water which contains about $10,000 \mathrm{mg} / 1$. The recommended 1 imit for livestock is about $5,000 \mathrm{mg} / 1$. The maximum limit for dairy cattle should not exceed $7,150 \mathrm{mg} / 1$. Water containing high concentrations of sodium and chloride is preferred to that which contain high concentrations of sulfate because of the laxative effect of sulfates.

The use of water for irrigation depends on many factors not directly associated wtih water composition. The bulk of the soluble salts present in the water supply is not taken up by growing plants but remains in the soil. However, concentrations of solutes in the soil cannot be allowed to rise too high because excessive concentrations interfere with the osmotic process by which a plant takes up water. Most of the mineral matter retained by crops are calcium and magnesium salts.

The extent and severity of the salt problem in irrigated areas depends on several factors besides the quality of the water supply: nature and composition of the soil and subsoil topography of the land, amount of water used, method of application, kind of crop grown, climatic conditions, and groundwater and surface water drainage. Sensitive crops, such as fruits and nuts, will generally tolerate 500- 
$1,000 \mathrm{mg} / 1$ of dissolved solids, while moderately salt-tolerant plants, such as alfalfa and many garden crops, on permeable soils with careful management practicess, will tolerate considerably higher concentrations.

Plant species vary greatly in the amounts of sodium they may accumulate, and few well-defined instances of sodium toxicity have been found. Very low concentrations of boron are essential to the normal growth of all plants but even low concentration's may cause injury to plants. Most vegetable and grain crops are at least semi-tolerant of boron, but nut and fruit crops are not. Boron may occur in limited, scattered areas of arid or semi-arid regions, and excessive boron is frequently present in saline soils. However, excess boron has not been found to be a great problem in New Mexico.

Quality requirements for industrial water varies widely, and each industrial application has its own standards. For many industrial applications, such as cooling or condensation, chemical quality is critical.

One sample can define adequately the water quality at a given time, if the mixture of solutes throughout the stream cross-section is homogeneous. However, the concentration of solutes at different locations in the cross-section may vary widely with different rates of water discharge, depending on the source of material and the turbulence and mixing of the stream. Some streams must be sampled through several vertical sections to obtain a representative sample needed for accurate mean concentration and use in calculating load.

For measurements such as $\mathrm{pH}$ and specific conductance, field values are considered to be more representative than laboratory values; however, if a sample changes very little between the time it is collected and the time it is measured in the laboratory, and i.f the laboratory method is more accurate than the field method, the laboratory value may be better.

The chemical analyses of composite samples in this report generally represent discharge-weighted composites which range from one-day composites to 30-day composites. The composite periods are selected on the basis of chances in the specific conductance of individual samples and fluctuations in streamflow.

Groundwater quality at a site generally does not change significantly during a short period. Changes in quality may be defined adequately by sampling as infrequently as seasonally or annually.

Water temperature is an important parameter of water quality. Water temperature is a deciding factor in the makeup of the aquatic ecosystem, and fluctuations in water temperature have been known to cause fish-kills and, if extreme, may result in the destruction of aquatic vegetation.

Suspended sediment concepts are described by Guy (1969), and the techniques for sample collection, analyses, and measurement of 
suspended-sediment are described by Guy and Norman (1970). Methods for computation of fluvial sediment discharges are described by Porterfield (1972). Suspended-sediment concentrations are determined from samples collected by using depth-integrating samplers. Samples usually are obtained at several verticals in the cross-section, or a single sample may be obtained at a fixed point and a coefficient applied to determine the mean concentration in the cross-section.

Generally two types of biological data appear in reports: (1) microbiological data on coliform and streptococci bacteria, and (2) aquatic biological data on benthic (bottom dwelling) organisms. prescribed methods for the collection and analysis of aquatic biological and microbiological samples are being developed by the U.S. Geological Survey.

Coliform and streptococci bacteria are indicators of animals waste discharges into a stream or aquifer because these organimsms are present in the intestinal tract of warm-blooded animals. These organisms are short-lived and relatively harmless, but their presence in a water supply suggest recent contamination and a possibility that dangerous bacteria may a1so be present.

\subsection{Geotherma1 Waters}

New Mexico's geothermal water has received additional study. Swanberg (1979b) made an "Open File Report" titled "Geochemical Data from New Mexico Geothermal Waters." Included in this report are temperatures and locations of approximately 300 springs and wells in New Mexico and West Texas. One-third of these are springs, the rest are we1ls.

Three temperature measurements were made. These were: actual, $\mathrm{Na}-\mathrm{K}-\mathrm{Ca}$ estimation, and silica estimation. Map or quadrangle name, latitude and longitude, and range and township were given.

Water chemistry data included the following: TDS, pH, Ca, Mg, Na, $\mathrm{K}, \mathrm{CO}_{3}, \mathrm{HCO}_{3}, \mathrm{Cl}$, and $\mathrm{SO}_{4}$ in milligrams per liter for most sites; iron, fluoride, boron, phosphorus, and silica in ppm for most sites; nickel, lead, antimony, selenium, strontium, and zinc in ppm for approximately one-half of the sites; cadnium, cobalt, chromium, copper, mercury, hydrogen sulfide, lithium, manganese, molybdenum, ammonium, silver, aluminum, arsenic, barium, and bromine in $\mathrm{ppm}$ for about one-third of the sites. The chemical quality of geothermal springs and wells varied considerably. The highest TDS reported in this data was $220,152 \mathrm{mg} / 1$, and the lowest $40 \mathrm{mg} / 1$. The highest $\mathrm{pH}$ recorded was 10.56 and the lowest 6.69. Hydrogen sulfide $\left(\mathrm{H}_{2} \mathrm{~S}\right)$ was reported at a high of $5.8 \mathrm{ppm}$ at one well and at a low of $<0.1 \mathrm{ppm}$ in 47 wells and springs. Since few geothermal resource areas have been tested to depth, the specific chemical quality of an individual resource area is not known. These data are generally collected during the exploration phase of geothermal development. 


\section{2 .2 Current Monitoring Activities}

Historically, there has been concern over water in New Mexico. This concern has reflected the paucity of the resource, and has led to extensive monitoring programs to protect the limited amounts of water present in the state. The Geological Survey began investigation of groundwater supplies while New Mexico was still a territory; nine water supply papers concerned with groundwater had been published prior to New Mexico's gaining statehood in 1912. Since that time, many advances have been made in monitoring programs, and as such, there is active monitoring of water in many parts of the state.

\subsubsection{Quantity of Water}

Most of the surface water gaging of stream flow is accomplished by the Geological Survey through a network of regular recording gaging stations in the state (Figure 31). There were also 15 stations along the border in adjacent states being operated to provide streamflow data for New Mexico. It is interesting to note that the first gaging station established in the United States by the Geological Survey was on the Rio Grande at Embudo in January 1889. Streamflow records for that station extend from 1889 to the present time.

The base data collected at gaging stations consists of records of stage and measurements of discharge of streams or canals and stage, surface area, and contents of lakes or reservoirs. In addition, observations of factors affecting the stage-discharge relationship or the stage-capacity relationship, weather records, and other information are used to supplement base data in determining, the daily flow or volume of water in storage. Records of stage are obtained from a water-stage recorder that gives a continuous graph of the fluctuations or from direct readings on a nonrecording gage. Measurements of discharge are made with a current meter using the general methods adopted by the Geological survey on the basis of experience in stream gaging since 1888. Surface areas of lakes or reservoirs are determined from instrument surveys using standard methods. The configuration of the reservoir bottom is determined by sounding at many points.

The data in the 1972 Water Resources Data for New Mexico, Part 1, (USGS,1974) generally comprise a description of the station and tabulations of basic data. For gaging stations on streams or canals, the daily discharge and monthly and yearly discharge is available. For gaging stations on lakes and reservoirs, a monthly summary table of stage and contents or a table showing the daily contents is given. Tables of daily gage heights or elevations are included for some reservoir stations.

The description of the gaging station (USGS, 1974) gives the location, drainage area, period of record, type of gages, history of gages, average discharge, extremes of discharge, and general remarks. The type of gage currently in use, the datum of the present gage above mean sea level, and a condensed history of the types, locations and 


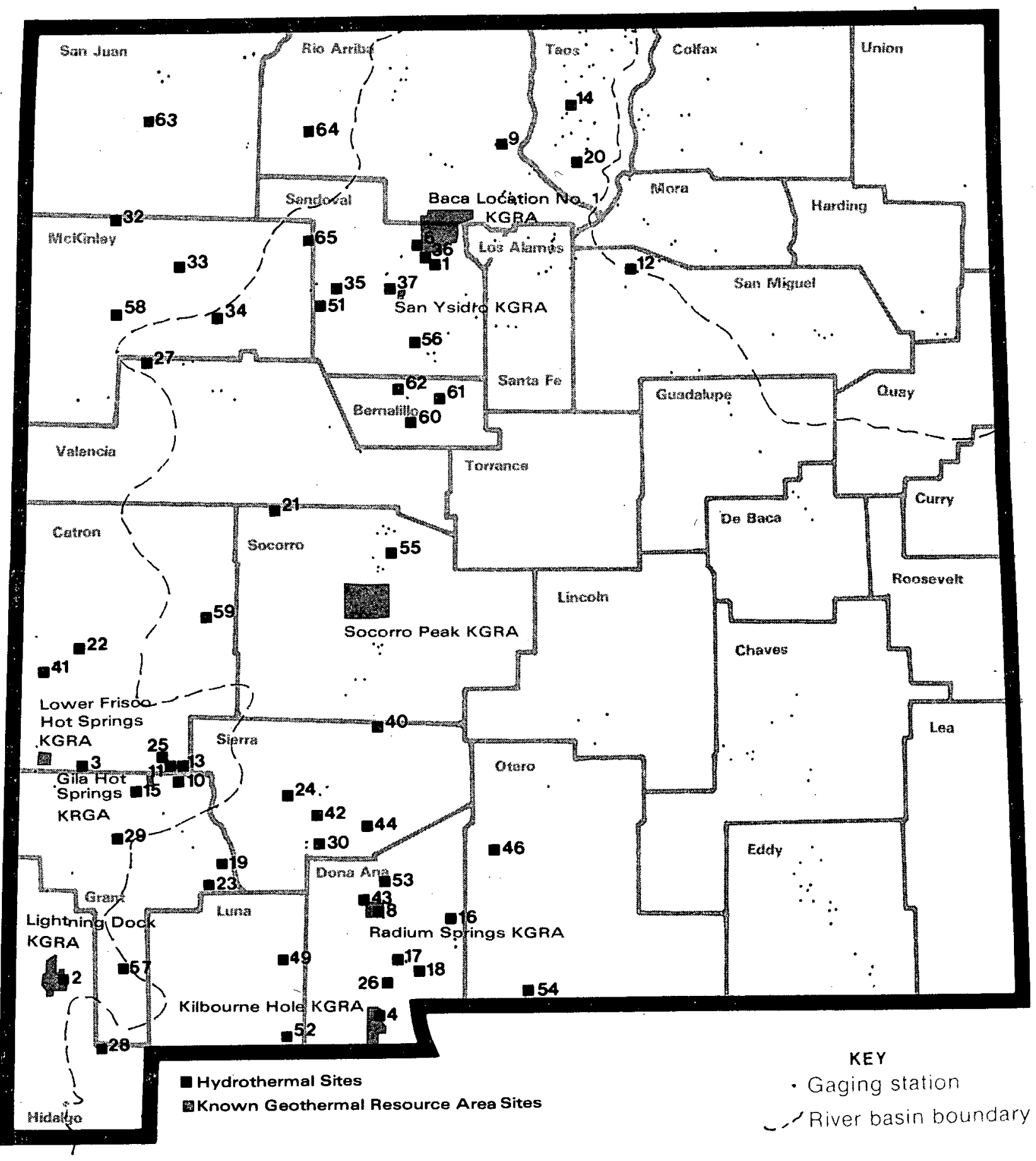

Figure 31. Location of USGS streamflow-gaging stations in New Mexico in 1970 (State of New Mexico, 1.976). 
datums of previous gages used during the period of record are given. The average discharge for the number of years indicated is given for stations having five or more complete years of record. The minimum daily discharge is given if there is extensive regulation. Information pertaining to the accuracy of the discharge records, to conditions that affect the natural flow at the gaging station, and to availability of water Quality records, is given.

Surface water drainage basins are also monitored for water quantity in a combined network of U.S.G.S., E.I.D., and Forest Service stations. The location of these stations in relation to geothermal sites is shown in Figure 32.

\section{2 .2 .2 Quality of Water}

The Geological Survey began collection quality-of-water data in New Mexico in 1905. In 1970 chemical-quality data were collected at about 50 stations, of which 13 were daily operations; and suspended-sediment data were collected at about 40 stations, of which 22 were daily operations. The locations of sampling stations where data on chemical quality and suspended sediment were collected in 1970 are shown in Figure 33.

Although some early chemical-quality records were taken, many of these stations were operated for only a short period of time. Published chemical analyses records for key stations are generally available for on 1y about ten years or less; in many cases, a total dissolved solids determination is not included. The chemical analyses extend to 1937 for a few key stations.

The average annual dissolved-solids discharge in selected reaches of stream and dissolved-solids discharge at selected stations, for the period 1951-1970, are depicted graphically in Figure 34. The dissolved-solids discharge for river reaches was determined by interpolating between stations. The annual. discharge at selected stations is shown by the bar graphs.

A graphic presentation of the average annual suspended-sediment discharge for selected reaches of stréams"at sélected stations for the period 1951-1970 is given in Figure 35. A reservoir in a stream system will trap all or part of the suspended-sediment discharge. The instance below reservoirs that the river has essentially no sediment load depends on sediment-laden tributary inflow and the erodibility of the river channel bed and banks. Most of the discontinuities on Figure 35, however, are due to insufficient data rather than to reservoirs. The bar graphs on the map show the amount of suspended sediment, in millions of tons, that is discharged annually at selected stations.

Water samples for analyses and water-quality field measurements usually are collected at or near points on streams where gaging stations are maintained by the U.S. Geological Survey for measurement of water discharge. Discharge records for streams in New Mexico have been 


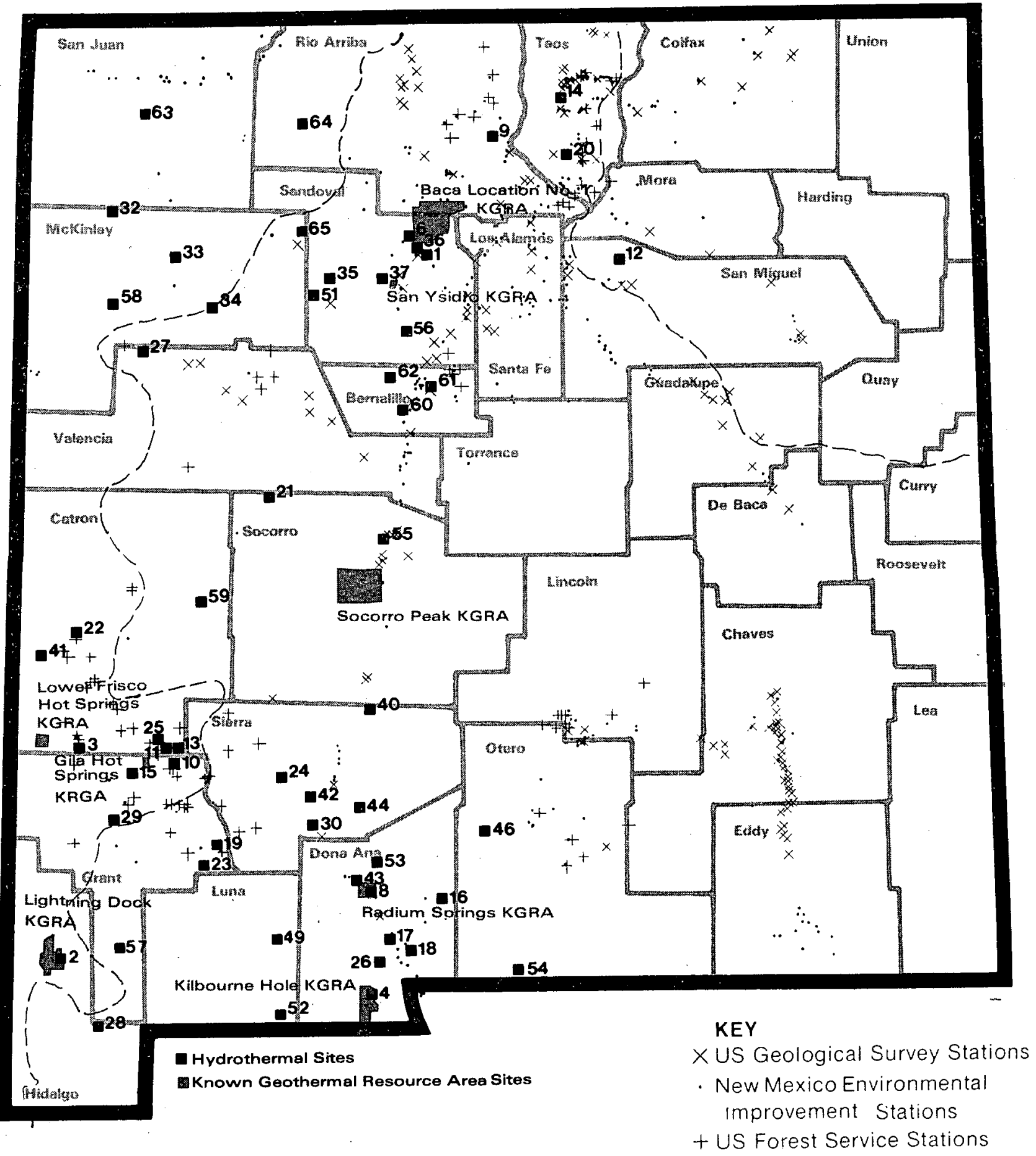

Figure 32. Surface water drainage basins monitoring sites in liew Mexico. 


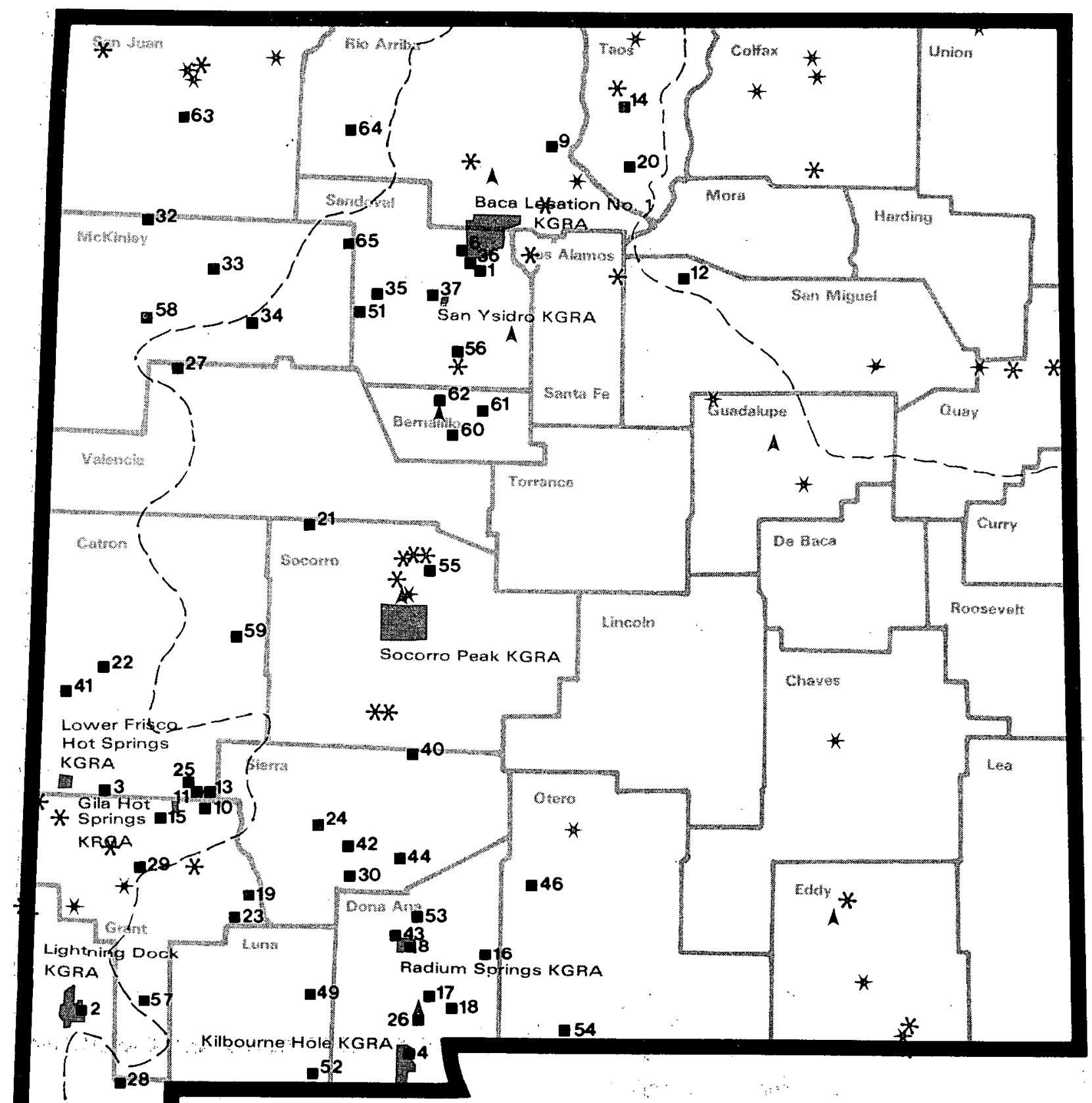

- Hydrothermal Sites

Known Geothermal Resource Area Sites

KEY

* Chemical quality

* Suspended sediment

Chemical quality

$A$ and

Suspended sediment

- River basin boundary

Figure 33. Locations of USGS chemical quality and suspended sediment sampling stations in New Mexico, 1970 (State of New Mexico, 1976). 


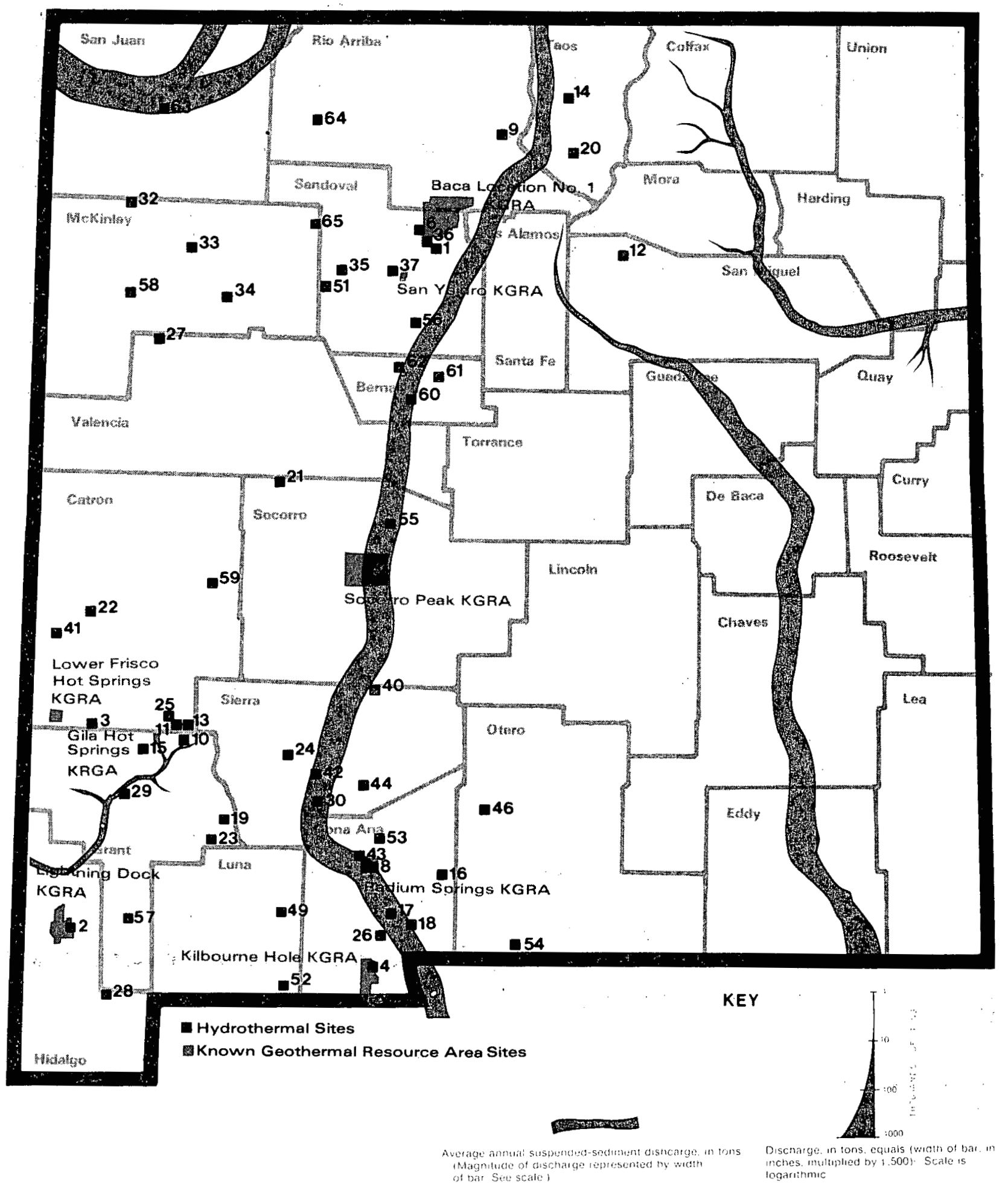

Figure 34. Average annual dissolved solid discharge in selected reaches of streams and dissolved solid discharge at selected stations in New Mexico, 1951-1970 (State of New Mexico, 1976). 


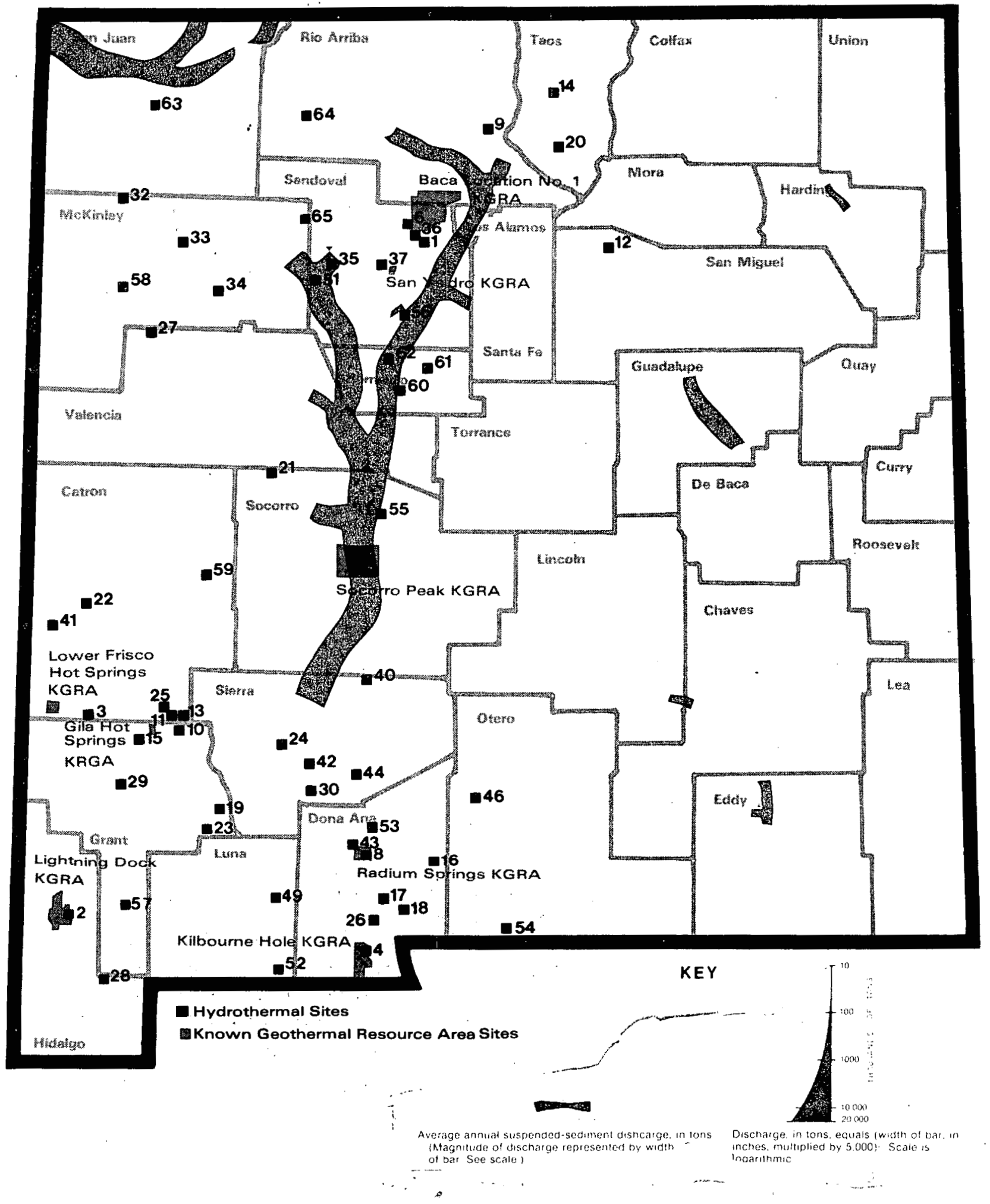

Figure 35. Average annual suspended sediment discharge in selected reaches of streams and suspended sediment discharge at selected stations in New Mexico, 1951-1970 (State of New Mexico, 1976). 
released in the report "Water Resources Data for New Mexico, 1972, Part 1, Surface Water Records". Mo'st of: these "records are used in conjunction with the computations and the chemical constitutents and sediment loads in this report.

The data, in Water Resources report includes a description of the sampling station and tabulations of the samples analyzed. "The description of the sampling station gives the location, drainage area, periods of record for the various water-quality data, extremes of the pertinent data, and general remarks, in a format similar to that used for streamflow gaging stations. For miscellaneous surface-water sites, no descriptive stations are given. For groundwater sites, no descriptive statements are given either. However, the well number, depth, date of sampling, and other pertinent data are given in the tables that contain the chemical analyses of groundwater.

Most methods for collecting and analyzing water samples to determine the kinds and concentration of solutes are described by Brown et al. (1970). The method for determining elemental constituents.by emission spectographic techniques is described by Barnett and Mallory (1971). Analysis of pesticides, herbicides, and organic substances in water are described by Georlitz and Lamar (1967); Lamar et al. (1965); and Georlitz and Brown (1972).

Water temperatures at all of the water-quality stations are taken at the same time water samples are collected. The water temperature records listed are daily water temperatures. Large streams have a small diurnal temperature change; shallow streams may have a dajly range of several degrees and may follow closely the changes in air temperature. Some streams may be affected by waste-heat discharges. At stations where continuously recording thermographs are used, the records consists of maximum, minimum and mean temperatures for each day. Monthly averages are also shown.

During periods of rapidly changing flow or rapidly changing concentration, samples may have been collected more frequently (twice daily, or in some instances, hourly). The published sediment discharges for days of rapidly changing flow or concentration were computed by the "subdivided day method" (time-discharge-weighted average). Therefore, for those days when the published sediment discharge value differs from the values computed as the product of discharge times mean concentration times 0.0027 , the reader can assume that the sediment discharge for that day was computed by the subdivided day method. For periods when no samples were collected, daily loads of suspended sediment were estimated on the basis of water discharge, sediment concentrations observed immediately before and after the periods, and suspended-sediment loads for other periods of similar discharge.

At other stations, suspended-sediment samples were collected periodically at many verticals in the stream cross section. Although data collected periodically may represent conditions only at the time of observations, such data are useful in establishing seasonal relations between quality and streamflow in predicting long-term 
sediment-discharge characteristics of the stream. In addition to the records of the quantities of suspended sediment, records of periodic measurements of the particle-size distribution of the suspended sediment and bed material are included.

The distribution and abundance of benthic organisms in a stream are related to the quality of that stream. Aquatic benthic organisms were collected by use of a square-foot surber sampler or artificial substrate. The surber sampler is a one-foot square frame with a conical net attached. The frame is implanted firmly on the bottom of a shallow stream, usually in the riffle zone. The stones, rocks, and gravels within the square frame are scrubbed and washed to dislodge any organisms which are then carried by current into the collection net. An artificial substrate is made by suspending a basket of rocks into a stream. After a specified period, usually six weeks to two months, the basket is removed from the stream, and any organisms are collected from the rocks. At least three sections within a stream cross section are sampled in an attempt to obtain a representative sample. The presence or absence of certain organisms in the benthic zone may be used as an indicator of the water-quality conditions within the stream.

Geothermal waters are being monitored only at drillsites in New Mexico. Probably the most extensive data is being collected at the Baca. Other data is being collected at the state's direct heat demonstration sites in Taos, Truth or Consequences, Las Alturas and Faywood Springs.

\subsubsection{Accuracy of Baseline Data}

Much data is available on surface and groundwater quantity and water quality in New Mexico. The four documents used in preparing much of this report represent an accurate "state of the art" on water quantity and quality data, with the exception of geothermal waters. The evaluation of data that follows is taken from these documents: New Mexico Water Resources Assessment for Planning Purposes (State of New Mexico, 1976); 1972 Water Resources Data for New Mexico Part 1, Surface Water Records, (USGS, 1974); 1972 Water Resources Data for New Mexico, Part 2, Water Quality Records (USGS, 1975); and Geothermal Data from New Mexico Geothermal Waters (Swanberg, 1979b).

The accuracy of discharge data depends primarily on (1) the stability of the stage-discharge relation or, if the control is unstable, the frequency of discharge measurements; and (2) the accuracy of observations of stage, measurements of discharge, and interpretation of records.

The station description in 1972 Water Resources Data for New Mexico, Part 1 under "REMARKS" states the degree of accuracy of the records. "Excellent" means that about $95 \%$ of the daily discharges are within 5\% accuracy; "good" within 10\%; and "fair" within 15\%. "Poor" means that daily discharges have less than $15 \%$ accuracy. 
Figures of daily mean discharge in the abovementioned report are shown to the nearest hundreth of a cubic foot per second for discharges of less than 1 cfs; to tenths between 10 and 1,000 cfs; and to three significant figures above $1,000 \mathrm{cfs}$. The number of significant figures used is based solely on the magnitude of the figure. The same rounding rules apply to discharge figures listed for partial-record stations and miscellaneous sites.

Discharge of some stations, as indicated by the month1y mean, may vary widely from natural runoff, due to the effects of diversions, consumptive use, regulation by storage, increases or decreases in evaporation due to artificial causes or other factors. Evaporation from a reservoir is not included in the adjustments for changes in reservoir contents.

Chemical-quality data published in this report are considered to be the most representative values available for the stations listed. The values reported represent water-quality conditions at the time of sampling as much as possible, consistent with available sampling techniques and methods of analysis. In the rare case where an apparent inconsistency exists between the reported $\mathrm{pH}$ value and the relative abundance of carbon dioxide species (carbonate and bicarbonate), the inconsistency is the result of a slight uptake of carbon dioxide from the air by the sample between measurement of $\mathrm{pH}$ in the field and determination of carbonate and bicarbonate in the laboratory.

In conclusion, where available, data on surface and groundwater quantity and quality will probably be adequate for a baseline determination of environmental parameters. Where the data is missing, potential geothermal development sites should have water testing done in a manner consistent with that required by the State Engineer's Office and other state and federal agencies. Data on waters' from geothermal reservoirs is conspicuously missing, for most of the sites. Both quantity and quality information at the depth of geothermal production wells should be documented during the exploration and development phases of a site-specific commercialization project. :

\subsection{Air Data}

One of the most important environmental elements that might be impacted by geothermal development is air. Air quality data collection and standards are increasingly dictated by legislation. Baseline air quality must reflect point-specific pollutants in order to separate pollution caused by geothermal development from other sources of pollution. With this in mind, possible pollutants, current monitoring in New Mexico current air quality regulations (both federal and state) and the quality of existing air data will be discussed. 


\subsubsection{Description and Measurement}

Because relatively 1 ittle is known about the geothermal waters of most of the geothermâl resources in New Mexico, the possible pollutants of geothermal waters discussed here are based on data from previous geothermal development in other areas. There may be no similarity between these geothernal waters and these in New Mexico. At various other resource areas the following chemicals and compounds have been discovered to be present in some degree: carbon dioxide $\left(\mathrm{CO}_{2}\right)$, hydrogen sulfide $\left(\mathrm{H}_{2} \mathrm{~S}\right)$, methane $\left(\mathrm{CH}_{4}\right)$, hydrogen $\left(\mathrm{H}_{2}\right)$, ethane $\left(\mathrm{C}_{2} \mathrm{H}_{6}\right)$, mercury $(\mathrm{Hg})$, arsenic (As), boron ${ }^{4}(\mathrm{~B})$, nitrogen ${ }^{2}$ dioxide $\left(\mathrm{NO}_{2}\right)^{6}$ and carbon monoxide ( $\mathrm{CO})$. Another pollutant is total suspended particulate (TSP) material.

Data from thermal wells and springs in New Mexico (Swanberg, 1979b) indicate hydrogen sulfide levels of less than 0.1 to $5.8 \mathrm{ppm}$ (the majority of waters with $>0.1$ ), mercury levels of less than 0.0002 to $0.0148 \mathrm{ppm}$, arsenic levels of 0.001 to $0.160 \mathrm{ppm}$ and boron levels of 0.00 to $3.90 \mathrm{ppm}$. These data yield no information about the levels of carbon dioxide, methane, hydrogen, ethane, nitrogen dioxide or carbon monoxide. Although these data were taken from existing springs and wells, and not from geothermal wells at production depths, they may prove to be indicative of data from production depths in the same areas.

Data available from the state's air pollution monitoring network includes total suspended particulate (average $\mathrm{g} / \mathrm{m}$ in a 24-hour period), sulfur dioxide (average ppm in a 24-hour period), carbon monoxide (average $\mathrm{ppm}$ in an 8-hour period), ozone (average $\mathrm{ppm}$ in a 1-hour period) and nitrogen dioxide (average $\mathrm{ppm}$ in a 24-hour period). Hydrogen sulfide levels are not monitored, but point source measurement may be required of specific industry facilities within the state. Monitoring of other pollutants with established state standards occur in areas of the state where EID perceives there is a problem.

Areas of the state already exceeding federal and state standards for particular pollutants are:

1) carbon monoxide: Las Cruces, Farmington, Santa $\mathrm{Fe}$ and Berna1illo county;

2) total suspended particulates: Carlsbad, Albuquerque and an area near Hur1ey;

3) sulfur dioxide: San Juan County within a 2.5 mile radius of the Four Corners Power Plant and near Hurley within a 4.2 mile radius of the Kennecott Copper smelter; and counties.

4) ozone: Albuquerque, Las Cruces and portions of Lea and Eddy

Although inversions play an important role in the daily air quality in most valley regions of the state, little inversion data is collected in the state. The U.S. Weather Bureau at $E 1$ Paso and Albuquerque obtain data daily from weather ballon readings, but do not retain such data from year to year. If such data exists, it is retained at the National Records Center at Nashville, Tennessee. 


\subsubsection{Current Monitoring Activities}

The responsibility for the control of air pollution (and thus air quality) from any source in New Mexico is divided between the Environmental Improvement Board and the Environmenta1 Improvement Division of Health and Environment Division. These organizations have placed Bernalillo County under the auspices of the Albuquerque-Bernalillo County Air Quality Control Board and the Albuquerque Environmental Health Department (State of New Mexico, 1977).

These responsibilities have evolved from the state and federal standards (Table 8) for many air pollutants. State standards are not to be exceeded except for hydrogen sulfide which may not be exceeded more than once per year; federal standards may be exceeded once per year. Regulation and conformity to these standards require a monitoring system developed by the Environmental Improvement Board and maintenence by the Environmental Improvement Division.

The Environmental Improvement Board and the Environmental Improvement Division were created by the Environmenta1 Improvement Act in 1971. The EID is one of the six divisions within the HED and has the responsibility of enforcing rules, regulations and standards promulgated by the Environmental Improvement Board. The Environmental Improvement Board consists of five nembers appointed by the Governor upon the advice and consent of the State Senate. The members serve overlapping terms with no term to exceed five years. The Environmental Improvement Board has the responsibility of promulgating rules, regulations and standards relating to environmental management and consumer protection (State of New Mexico, 1977). This has 1ed, in turn, to the development of eight air quality control regions (Figure 36). The air quality control regions are both interstate (three) and intrastate (five). They cover all of New Mexico as well as parts of Texas, Arizona, Colorado and Utah. A11 of these regions (except Region Five) contain potential geothermal sites (Figure 36 ).

Ambient air quality monitoring units are located in the general vicinity of many potential geothermal sites in the sitate. Exceptions do exist, specifically in the vicinity of geothermal sites in western New Mexico. Prior to development of these resource sites, baseline data on air quality would need to be collected.

The ambient air monitoring units within each region sample for the following pollutants:

1. total suspended particulates (TSP);

2. sulfur dioxide $\left(\mathrm{SO}_{2}\right)$;

3. carbon monoxide (CO);

4. ozone $\left(\mathrm{O}_{3}\right)$; and

5. nitrogen dioxide $\left(\mathrm{NO}_{2}\right)$. 


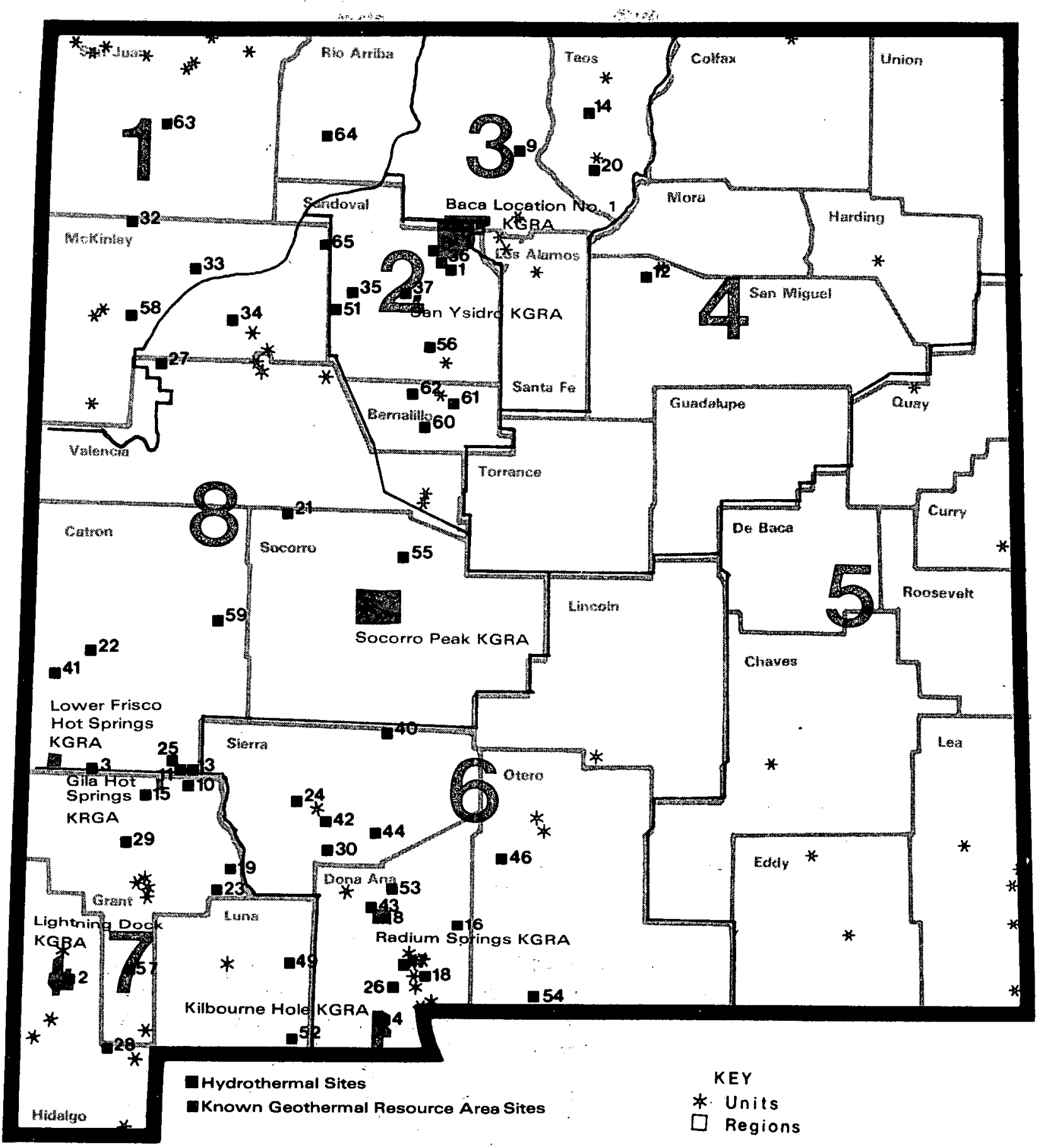

Tigure 36. Air quality control regions and ambient air monitoring units for the State of New Mexico (State of New Mexico, Air Quality Section, 1977). 
A complete description of sampling methods may be found in State of: New Mexico, Air Quality Section (1977). Table 9 presents the possible pollutants, and the monitoring frequency and coverage provided by existing monitoring units in New Mexico.

These ambient air monitoring units within each region (Figure 36) were established to provide accurate and valid data to:

1. insure that New Mexico air quality standards are being met;

2. establish background concentrations;

3. provide a warning about possible effects of an air contaminant or group of contaminants that will allow the director of the EID to make accurate judgments during an emergency episode;

4. evaluate air pollution trends which will allow the staff to evaluate the effects of land use planning, industrial growth, transportation planning, population growth and air quality control regulations; and

5. detect sources that may cause violations of ambient air quality standards (State of New Mexico, Air Quality Section, 1977).

Monitoring of visibility is also being conducted in New Mexico by the National Park Service. Data is presently being taken at Bandelier National Park, Carlsbad Caverns, Chaco Canyon, and White Sands National Monument. These data are being taken in response to the visibility Protection section of the 1977 Clean Air Act Amendments, which was mentioned previously and sumnaries of these data are obtainable from National Park Service personnel at those sites.

\subsubsection{Accuracy of Baseline Data}

Quality assurance activities are performed as a portion of the air monitoring network. The monitoring unit receives guidance from the U.S. Environmental protection Agency and participates in audit programs with Rockwell International (the Environmental. Protection. Agency Western Energy Quality Assurance Contractor) and with the Environmental Protection Agency. The Environmental Improvement Division (M. Rinaldi, pers. comm.) has great confidence in the data take since the initiation of quality assurance. Prior to that time, all data had to be carefully evaluated to determine validity.

The establishment of background concentrations of air pollutants currently defined by state and national standards will aid the potential geothermal developer. At present, major pollution problems in New Mexico are close to heavily populated areas or near several large industries. The entire state suffers from occasional high concentrations of total suspended particulate matter due to natural wind-blown dust. 
Table 9. Monitoring frequency and coverage of air pollutants that may be associated with geothermal development.

\begin{tabular}{|c|c|c|}
\hline Pollutant & Monitoring Frequency & Monitoring Coverage \\
\hline arsenic & none & none ${ }^{1}$ \\
\hline beryllium & none & none \\
\hline boron & none & none \\
\hline carbon monoxide & daily & all units \\
\hline hydrogen sulfide & none & none \\
\hline sulfur dioxide & daily & all units \\
\hline nitrogen dioxide & daily & all units \\
\hline photochemical oxidants (ozone) & daily & all units \\
\hline hydrocarbons & none & none \\
\hline heavy metals & none & none \\
\hline total suspended particulates & daily & all units \\
\hline total reduced sulfur & none & none \\
\hline mercury & none & none \\
\hline methane & none & none \\
\hline ethane & none & none \\
\hline fugitive dust & none & none \\
\hline
\end{tabular}

${ }^{1}$ Spot monitoring occurs in EID-identified problem areas, frequency is a 24 -hour sample every 6 days. 
Air monitoring units, however, are conspicuously missing for geothermal sites in Catron County and in the vicinity of 36 geothermal sites. Other sites may not be close enough to be monitoring units to determine complete baseline data. It would be necessary to evaluate the completeness of available data for the establishment of a baseline in the vicinity of a particular site in order to determine if further data collection activities were necessary.

Further, a1though the state has standards for some pollutants, namely arsenic, beryllium, boron, hydrogen sulfide, hydrocarbons, heavy metals, total reduced sulfur, mercury, methane, ethane and fugitive dust, its ambient air monitoring system does not provide any baseline data on the quantity or frequency of these pollutants. Spot monitoring does occur in EID-identified problem areas. Environmental baseline data on these pollutants, if indicated in the quality of the geothermal brine, would need to be established prior to any facility operation.

Inversion data, if obtainable is probably not sufficiently site-specific to be of value, except perhaps in the Albuquerque area.

\subsection{Noise and Noise Pollution Data}

Noise is the most subtle and possibly the most widespread pollutant that man encounters. Many times it annoys, but it can also constitute a danger to human health and wildlife habitat. In New Mexico, noise pollution is not considered to be an important environmental impact from any source (including geothermal development), in light of the lack of any state laws or regulations and the minimun participation of towns and cities in enacting noise legislation. Where noise legislation exists, it is most often aimed at controlling vehicular noise emissions rather than industrial noise levels. Indeed, OSHA work-related standards are the primary regulations that would affect geothermal development in New Mexico at the present time. This lack of regulation is reflected in the lack of available data and paucity of monitoring stations.

\subsubsection{Description and Measurement}

Noise is sound. Sound is produced by waves traveling through air in a manner similar to waves traveling through water. As in water, the higher the waves the greater their power. The greater the number of waves, the greater the frequency or pitch of the sound. The frequency of sound, or pitch, is measured in Hertz (Hz, or cycles) per second. Norma1 human hearing ranges from $20 \mathrm{~Hz}$ to $20,000 \mathrm{~Hz}$, or approximately the range from the lowest note on a pipe organ to the highest note on a violin (Environmental Protection Agency, 1977b).

Strength of sound, or noise level, is measured by decibels (dB). The decibel is based on a logarithmic scale. Therefore, a small 
increase in decibels represents a great increase in the intensity of the sound. For example, while ten decibels is ten times more intense than one decibel, 20 decibels is 100 times more intense $(10 \mathrm{x} 10$ rather than $10+10)$. Table 10 lists examples of well-known sources of sound. These can be compared with noise measurements at The Geysers power generating facility (Table 11), which uses dry steam geothermal resources. Noise levels from liquid-dominated sources for electrical generation will likely be similar (Hartley, 1978).

The expression dBA means "A-weighted" sound level measured in decibels above a reference sound pressure of 0.0002 microbars. "A-weighting" weights the contributions of sounds of different frequency so that the response of the human ear is simulated (since the human ear cannot perceive all sound frequencies).

\subsubsection{Current Monitoring Activities}

In New Mexico baseline data is being monitored only in cities with noise abatement regulations (Albuquerque, Farmington, Los Alamos, Socorro and Red River) and perhaps by some federal agencies (Federal Aviation Administration and the Department of Defense, near military bases). Only Albuquerque has regulations regarding drilling noise that may affect geothermal development. However, one or two readings of baseline data at a site prior to any development" should present sufficient data to determine noise levels attributable to geothermal use and development.

\subsubsection{Accuracy of Baseline Data}

Baseline data for noise pollution and abatement related to industrial development, specifically geothermal development; is virtually non-existent, except perhaps at the Baca and LASL hot, dry rock demonstration sites. The most usefule baseline data currently available may be that associated with geothermal resource sites near military bases and available from the Department of Defense. The.City of Albuquerque may also have adequate background noise data. Complete baseline data does not exist elsewhere in the state, since even those cities with noise abatement regulations tend to focus only on vehicular traffic data.

It is recommended, therefore, that a few sample readings be taken on geothermal development sites prior to the construction of permanent facilities, in order to establish an adequate sampling of background noise. If development activities are too disruptive to obtain an adequate sampling, sampling of nearby undisturbed area might provide adequate substitute data. 
Table 10. Examples of well-known sources of sound (Hartley, 1978).

Source of sound

quiet wilderness area

quiet suburban residence

business office

noisy urban area

adjacent to freeway

jet airplane at 100 feet
dBA Range

$20-30$

$48-52$

$50-60$

$80-90$

90

$120-130$ 
Table 11. Sound levels from various noise sources at the Geyers, California geothermal electrical generation facility Hartley, 1978).

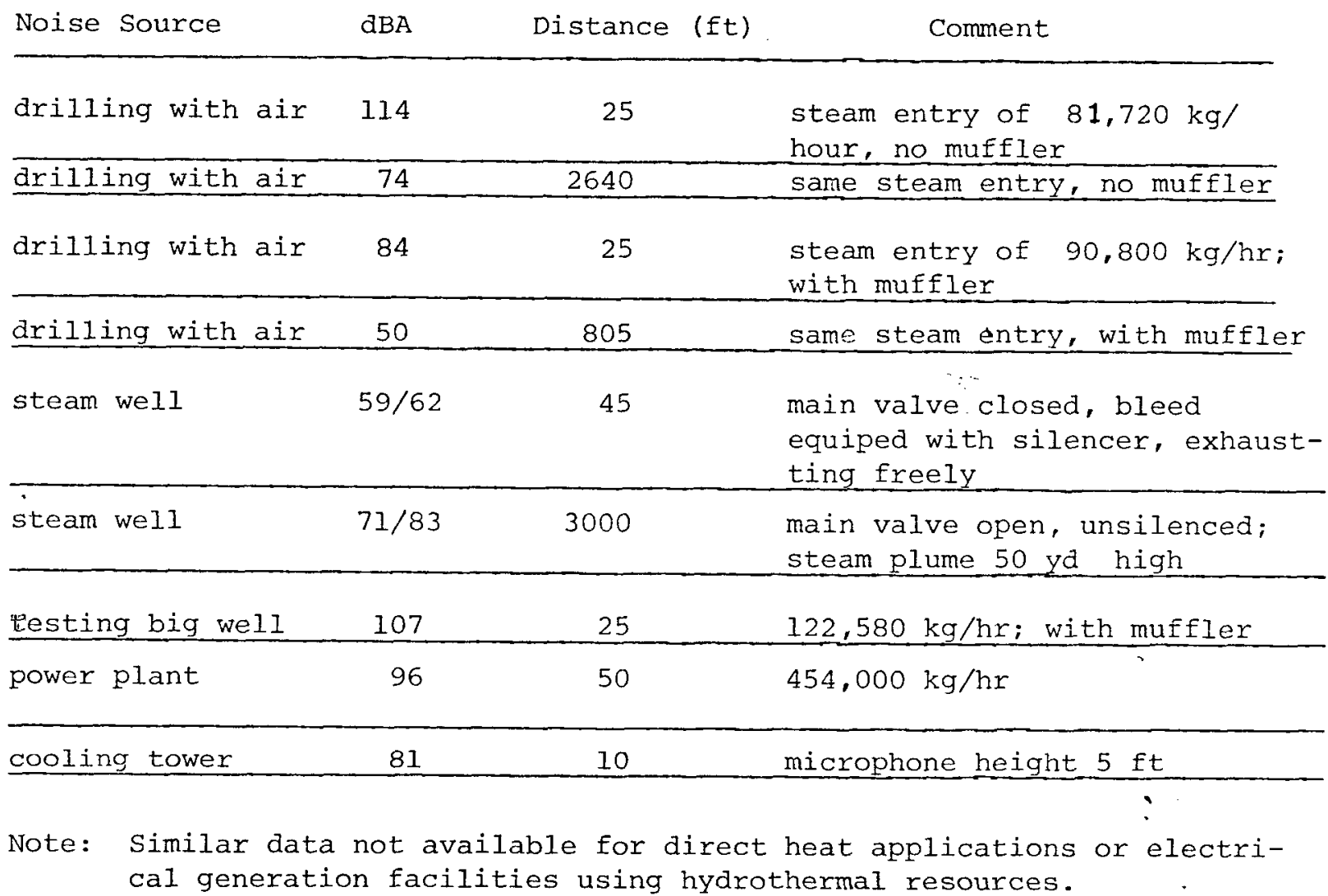




\subsection{Biotic Data}

Biota has been chosen for this section rather than ecosystems or ecology. Virtually all natural ecosystems in New Mexico are presently impacted to some degree by man's activity. The human species must, of course, be considered a bona fide component of natural ecosystems. However, the human activity of concern here is that which is peculiar to "modern" man and which is capable of greatly modifying natural ecosystems.

It must be remembered that ecosystems include abiotic as well as biotic components. Consequently, perturbations in any or all of the abiotic features being addressed in this document--such as geophysical, water, air, etc.--will affect ecosystems. Ecosystem changes resulting from modifications of ecosystem components are difficult to assess and virtually impossible to predict at the present time. Ecology is the study of ecosystems and is primarily concerned with interactions (dynamics) of ecosystem components.

From these comments it is understandable that the best that can be done for a study of this kind is to describe the existing biota (flora and fauna) of the area under consideration for geothermal development. Then a crude prediction of the possible impacts on these biota can be attempted. Little ecology will be involved, and hence, no ecosystem analyses will result.

\subsubsection{Description and Measurement}

New Mexico has a highly varied biota due to the great size and topographic heterogeneity of the state. Consequently, it is highly likely that geothermal energy development will impact different biotic arrays at each different site.

Most of the state's biota has been and is being impacted by man to some degree. It should be recognized that there are few, if any, pristine (virgin) plant or animal communities left in the state. However, concerted efforts should be made to safeguard at least examples of the most natural of these different communities found in our state.

To preserve benchmark examples of New Mexico's biotic diversity, we must first know with what diversity we are dealing. Then we have to know the locations and extend of the diverse units (communities). If this information is available, we can be in a position to objectively judge the seriousness or threat of any given impact on the biota of the state.

\section{5 .1 .1 Flora}

\section{5 .1 .1 .1 Vegetation}

Virtually all major terrestrial vegetation types found in the conterminous United States are also found in New Mexico. These are 
tundra, forest, woodland (savanna), scrubland, grassland, riparian (peculiar to drainage systems), and desert. Many of these major units (formations) have important subunits which are extensive in the state. Most of these subunit composed of recognizable species aggregations, sometimes referred to as community types. There are approximately 65 different series (associations) and 165 cominunity types in New Mexico. The numbers are approximate due to lack of sufficient data from some areas and possible differences in interpretation of the relative discreetness of some units.

The U.S. Forest Service is in the process of classifying the vegetation on its lands. They are using a modified-Daubenmire system which attempts to identify relatively stable (mature) species assemblages called "habitat types". The term "habitat type" is not applied unless or until a sufficient number of stands have been studied to indicate repetitive similarities to warrant the designation. The Forest Service has almost completed typing the higher elevations, is well along on the middle elevations, and is beginning the lower elevation vegetation. When completed, the tundra, forest, and woodland formations found on U.S. Forest Service land will be classified. The system lends itself well to use on Indian, state and private lands. The named community type can be changed to habitat type if and when a field survey indicates the unit has sufficient integrity to carry the name.

The Sojl Conservation Service has a series of technical guides containing range site descriptions. Even though these descriptions are for an applied use (grazing), the vegetation units are detailed and thorough. They are also consistent with the latest soil information for the state.

There are several vegetation maps for New Mexico. The most recent and best is "Potential Natural Vegetation, New Mexico, New Mexico Interagency Range Committee, Report No. 11, Soil Conservation Service, 1978." Due to the scale used, the smallest units on this map recognize diversity at a level well above (more general than) that of habitat or community type. "The smallest units on this map are similar to the series (association) category. . Figure 37 presents still more generalized vegetation types for the state.

Aquatic vegetation in New Mexico is less diverse than terrestrial, because there are relatively few aquatic habitats and water tends to reduce the heterogeneity of micro-habitats. Except for a few mountain streams and lakes, most aquatic vegetation is associated with man-modified and manipulated waters. This serves to further reduce plant diversity.

The New Mexico Heritage Office of the Division of Natural Resources in Santa $\mathrm{Fe}$ has some vegetation data (type, amount, location) on file in its data bank. This is available upon request.

The herbaria at the University of New Mexico and New Mexico State University contain extensive collections of plant specimens from New 


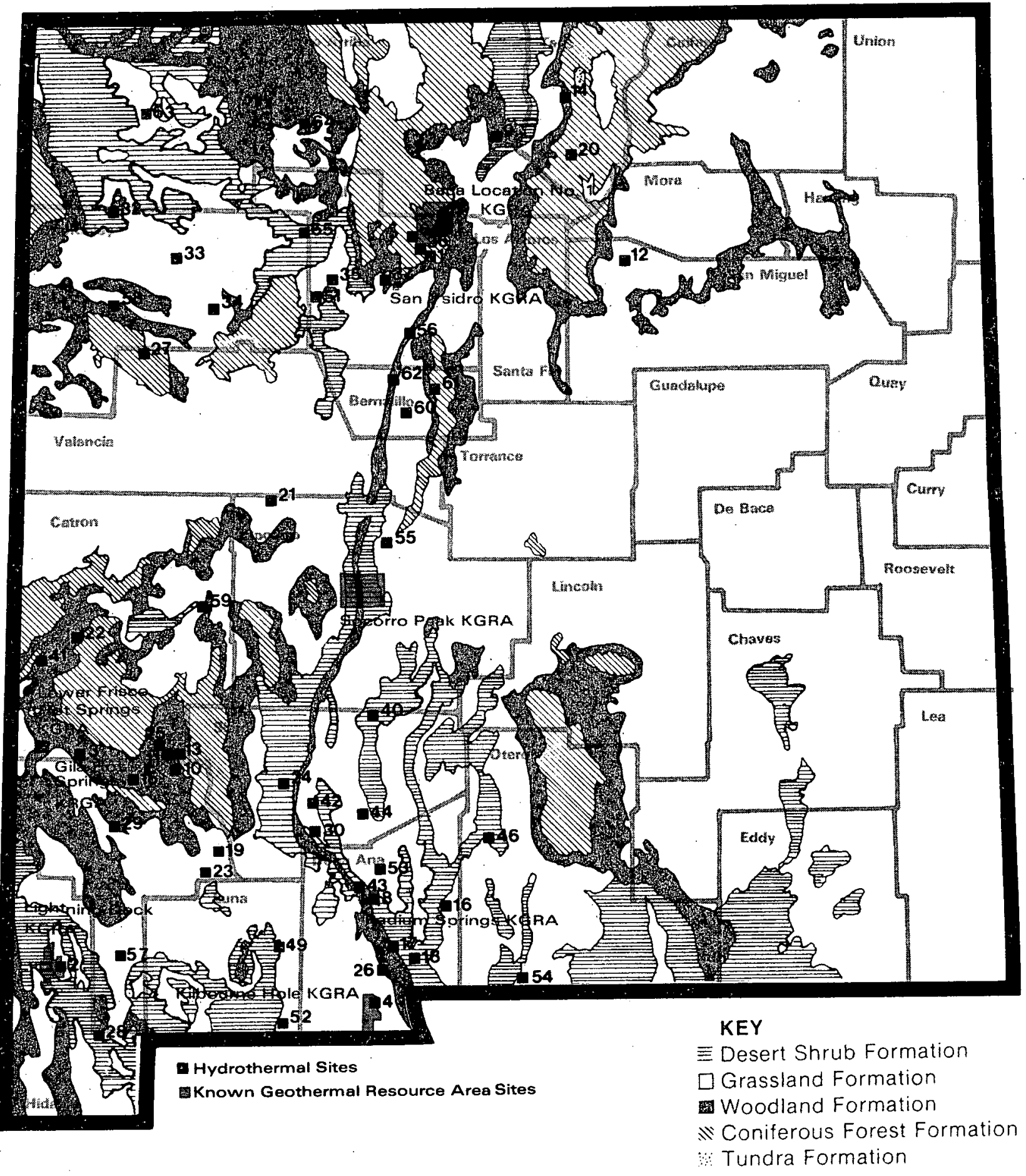

Figure 37. General vegetation patterns in New Mexico (Soil Conservation Service, 1.978). 
Mexico. Locations and generalized habitats can be obtained from the labels on these specimens.

A new "Flora of New Mexico" is in press and should be avajlable within the next year. This flora contains plates and range maps of most of the species included.

\subsection{Threatened and Endangered Species}

There are approximately 30 threatened and endangered plant taxa in New Mexico. A manual is being printed which gives descriptions, locations, and plates for the species in the state. The information to be included in the manual can also be obtained from the New Mexico Heritage office.

\section{5 .1 .2 Fauna}

The highly diverse topography, geography, and vegetation of New Mexico result in a diverse fauna in the state. Some elements of the High Rockies get into the state; Plains animals from prairies are found in the eastern portions of New Mexico; some Great Basin forms are found; and Sonoran animals are not uncommon in the southwestern corner. These are in addition to the Lower Rocky Mountain, desert grassland, Chihuahuan desert fauna.

\subsection{Animal Communities}

Most information on animal communities is located in research literature. The New Mexico Game and Fish Department has done some community type work. Occurrence and range data for individual species are fairly extensive. For vertebrates there are: Mammals of New Mexico (Findley et al., 1975), Guide to the Fishes of New Mexico (Koster, 1957), New Mexico Birds and Water (Ligon, 1961a), and New Mexico Birds and Where to Find them (Ligon, 1961b). There is also The Revised Checklist of the Birds of New Mexico (Hubbard, 1978). Dr. Sublette at Eastern New Mexico University has an extensive current data set on fish. There are fairly extensive reptile and amphibian collections at Western New Mexico University, New Mexico State University and the University of New Mexico. The University of . New Mexico and New Mexico State University also have extensive mammal, bird and insect collections.

Key wildife ranges and wildlife managements areas of the State of New Mexico are shown in Figure 38 and 39.

\subsection{Threatened and Endangered Species}

The threatened and endangered animal species are well documented in New Mexico largely due to the efforts of Dr. John Hubbard from the New 


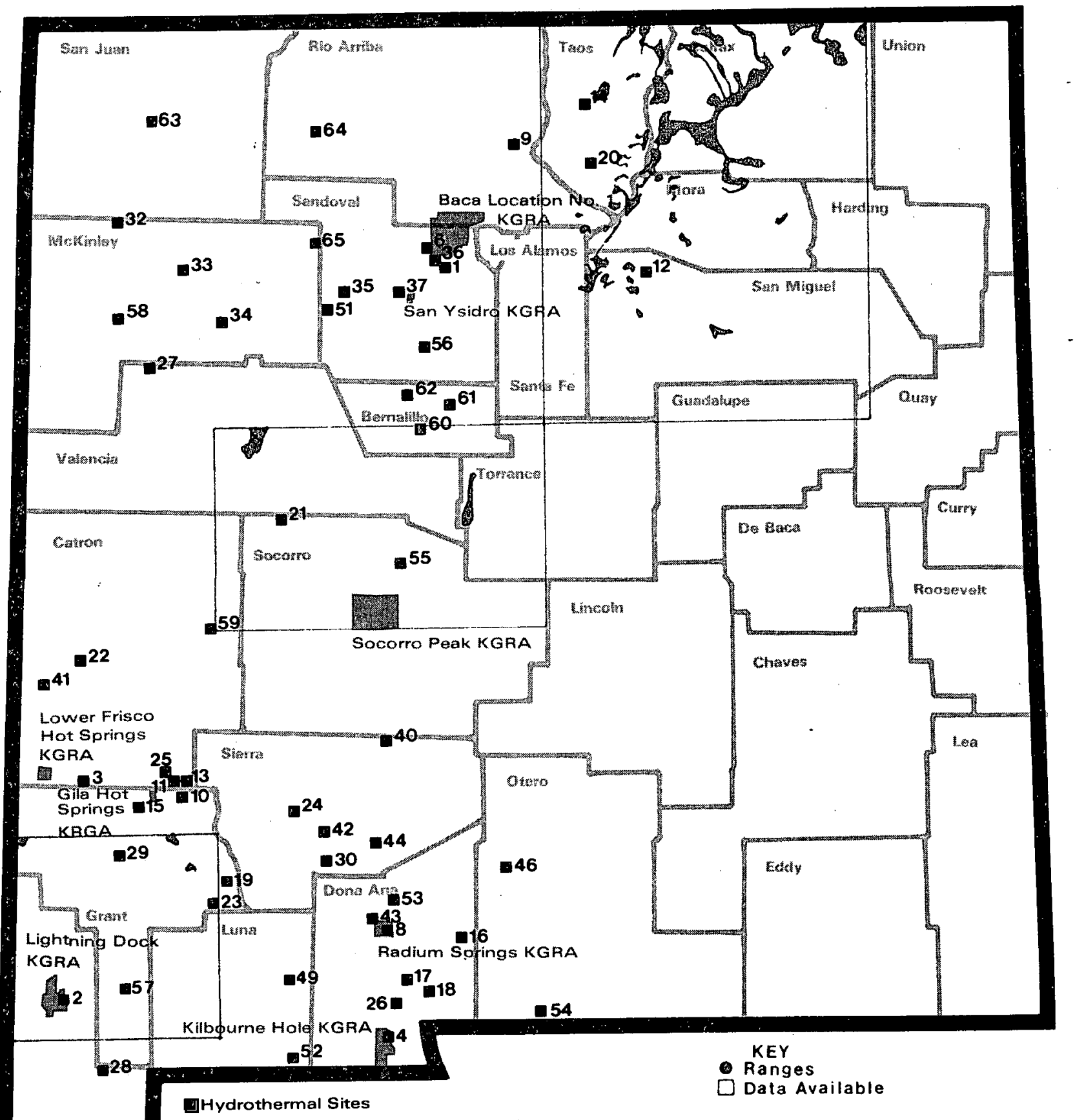

Hater

Known Geothermal Resource Area Sites

Figure 38. Key wild1ife ranges (State Planning Division, 1973). 


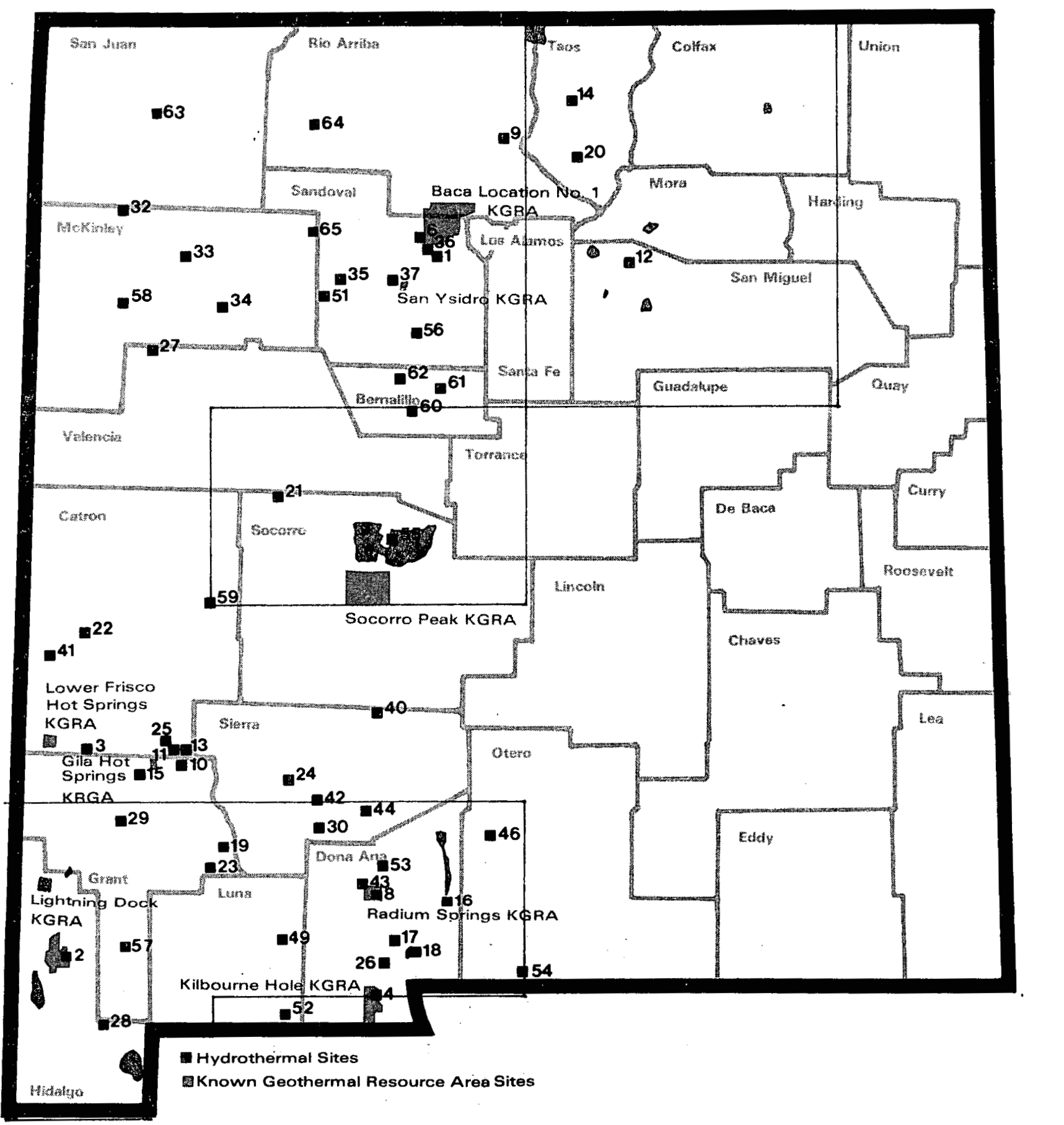

- Wildlife Areas

D Data Available

Figure 39. Wildlife management areas (State Planning Division, 1978). 
Mexico Department of Game and Fish. There is a manual for the vertebrates (Hubbard et al., 1978). The data from this manual plus additional data such as those obtained since publication of the manual and data on non-vertebrate animals is contained in the Heritage Program data bank and is available upon request.

\subsubsection{Current Monitoring Activities}

The Heritage office maintains a constant data acquisition and bank deposit system for all threatened and endangered species, new plant and animal occurrence sites, and bibliographic material such as publications and theses on plants and animals in New Mexico. The U.S. Forest Service Habitat Typing activity is continuing and in-service training sessions for habitat typing are planned so that precise locations and amounts (inventory) of the habitat types can be obtained. The Soil Conservation Service is constantly adding and correcting its range site description material. Figure 40 shows wilderness areas and Figure 41 natural areas in the state. Monitoring occurs in both areas to some degree.

\section{5 .3 Accuracy of Baseline Data}

General information on the biota of the state exists and is available. Most of the information can be found in the Heritage Program data bank or at least this data bank can be used to find out where the data are to be obtained. Animal occurrence and range information is relatively well known for the vertebrates. Vegetation data is not sufficient at the community type level and surveys and inventories will likely have to be conducted at each site of proposed development. The data on threatened and endangered species is good enough so that extensive searches will not be necessary at every site.

\subsection{Socioeconomic Data}

Socioeconomics deals with human-associated aspects--past, present, and future. This section considers impacts associated with geothermal development and people, including those things that would be encountered in the development of an environmental impact statement, including preservation of archaeological and historical sites; evaluation of recreation facilities and needs; cultural and economic considerations; land use and community services.

\subsubsection{General Socjoeconomic Data}

\subsubsection{Description and Measurement}

There is an extensive socioeconomic data base available from the Bureau of Business and Economic Research (1977), based on the last 


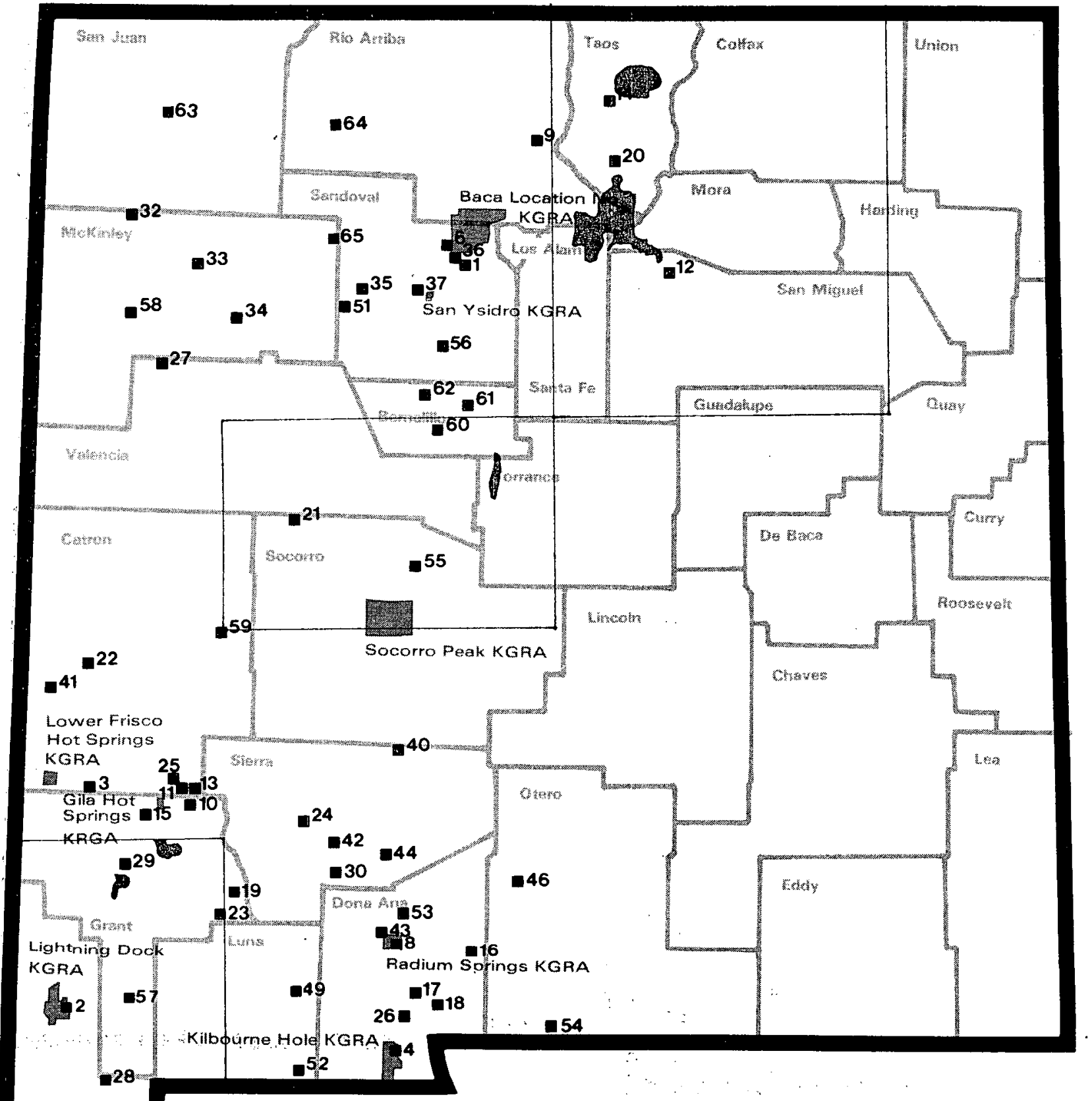

- Hydrothermal Sites

19.

Known Geothermal Resource Area Sites

Figure 40. Wilderness areas (State Planning Division, 1978). 


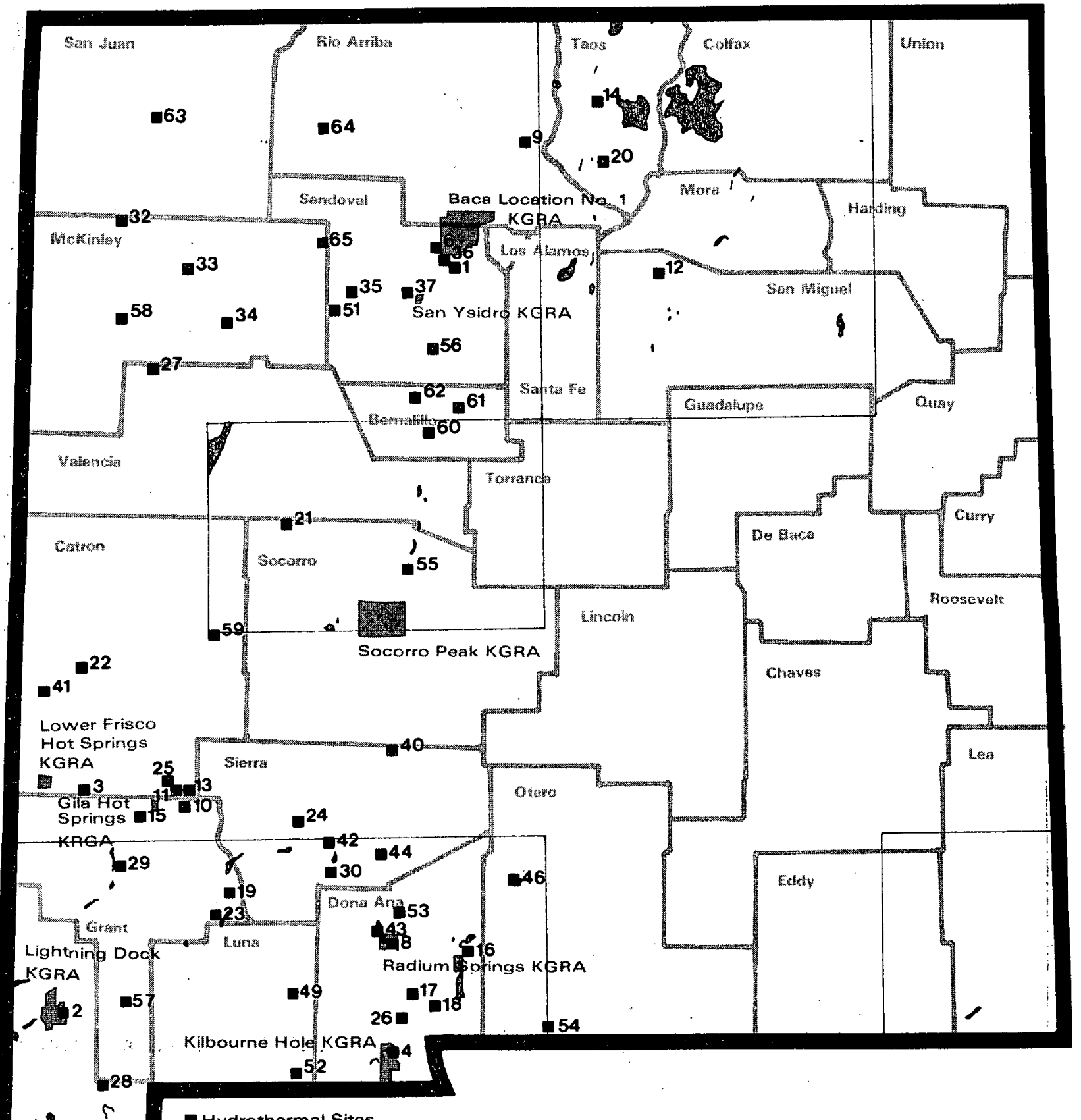

KEY

- Natural Areas

Data Available

Figure 41. Natural areas (State Planning Division, 1978). 
U.S. Census. Table 12 presents general data on New Mexico. Appendix E presents baseline data for the New Mexico counties that includes county area, population, matural increase in population, inferred migration, taxes and revenues, mining production, agricultural production, total retail sales, total wholesale receipts and total receipts of service.

\subsubsection{Current Monitoring Activities}

This basic socioeconomic data is made on projections (cohort survival and other techniques) from the most current U.S. Census Bureau statistics. Since new census data will be available from the 1980 survey, all socioeconomic data from this source should be considered "state-of-the-art" statistical data.

\subsubsection{Accuracy of Baseline Data}

With the addition of 1980 census data, information of this type should be very accurate for the next four-five years. After that point, inferences may throw a "skew" into the confidence levels of projections.

\subsubsection{Archaeological and Historical Sites}

In a state rich with cultural resources, protection of archaeological and hitorical sites must be carefully considered prior to development of any kind. In New Mexico, where numerous sites exist, this may become a problem of logistics. However, all sites must be located, described and evaluated prior to any geothermal activity.

\subsubsection{Description and Measurement}

In order to evaluate the problems caused when encountering archaeological or historical sites in a development area, one must first realize that they are generally considered to be any physical manifestation of cultural activities in the past. More precisely, they are defined as follows:

Archaeological resources--all evidences of past human occupations, which can be used to reconstruct the lifeways of past peoples. These include sites, artifacts, environmental and all other relevant information and the contexts in which they occur. Archaeological resources are found in prehistoric and aborginal sites and in Indian and European areas of occupation and activity.

Historical resources-all evidences of human occupations that date from historic, i.e., recorded history, periods. These resources include documentary data, i.e., written records, archival material, photographs, maps, etc.; sites, artifacts, environmental data and all other relevant 
Table 12. General socioeconomic information about the state of New Mexico (Bureau of Business and Economic Research, 1977).

State Area:

State Capital:

Population:

Population Components (1970):

$\%$ Rural

$\%$ Nonwhite

$\%$ Spanish-heritage

$\%$ Over age 65

Vital Statistics:

Births

Deaths

Natural increase

Inferred net migration

Education:

180 day average pub7 ic school enrollment

Employment:

Manufacturing

Mining

Contract construction

Transportation, public utilities, communication Wholesale and retail trade

Finance, insurance and real estate

Services

Government

Total nonagricul tural

Unemployment rate

Welfare (1975):

$\%$ of population of food stamp program

Income (1974):

Average per capita

Agricultural (1969):

Average farm size

Average value of land and buildings

Trade and Services (1972):

Total retail sales

Total wholesale receipts

Total receipts of services
$77,866,240$ acres

Santa Fe, New Mexico

30.2

9.9

40.1

6.9

106,707

39,372

67,335

60,570

271,431

$\$ 29,100$

19,000

24,700

23,200

79,600

16,300

64,900

102,200

359,000

$6.3 \%$

13.74

$\$ 4,139$

4,020 acres

$\$ 168,336$
$\$ 2,300,272$

350,784

753,920 
information. Historic resources are cultural resources and may be considered archaeological resources when archaeological work is involved in their identification and interpretation.

Many times, discovery of such sites may affect location or type of energy development, (P. Beckett, pers. comm.).

Geothermal exploration or development may be retarted until an adequate site specific survey can be made. In areas where hot springs or other surface hot water is present, there may be an unusually large number of sites. An excellent example of this is Faywood Hot Springs (23). Not only are the springs of historical interest, being the site of the Faywood Hotel, but they were also the site of Spaulding's training camps at the turn of the century. When the hotel site was being developed (circa 1880), there were reports of extensive Indian sites in the area. This included discovery of many artifacts in the area as well as at the spring itself.

These surface hot water sites apparently had an appeal to both the Indian and early European settlers in New Mexico. Frequently these sites had some sort of reljgjous significance to the Indians. Later, with the onslaught of settlers, these sites were developed as mineral baths, resorts, etc. Extensive site-specific data is available from the Museum of New Mexico and the State Archaeologist at the New Mexico Laboratory of Anthropology.

\subsubsection{Current Monitoring Activities}

Current monitoring or mapping of archaeological and historical sites is underway. However, in most of New Mexico, probably no more than $10 \%$ of the surface area has been examined. Much of the state has had less than 10\% surveyed, perhaps as little as one-half of one percent (P. Beckett, pers. comm.).

Because of the concern over these resources, the State of New Mexico, State Planning Division, has prepared maps showing areas of potential for high density sites (Figure 42 and 43). These may serve as a tool to provide potential developers with an estimation of site density, from which to judge the intensity of baseline data acquisition needed. Figures 44 and 45 show the location of historic sites and religious shrines in New Mexico.

\subsubsection{Accuracy of Baseline Data}

The availability of data is, as mentioned previously, limited to those areas which have been surveyed. Data from surveyed areas is likely to be quite accurate. Maps on various achaeological studies are available for the development of Environmental Impact Statements. These maps are not released to the public (C. Schaafsma, Museum of New Mexico, pers. comm.), but the general maps provided by the State 


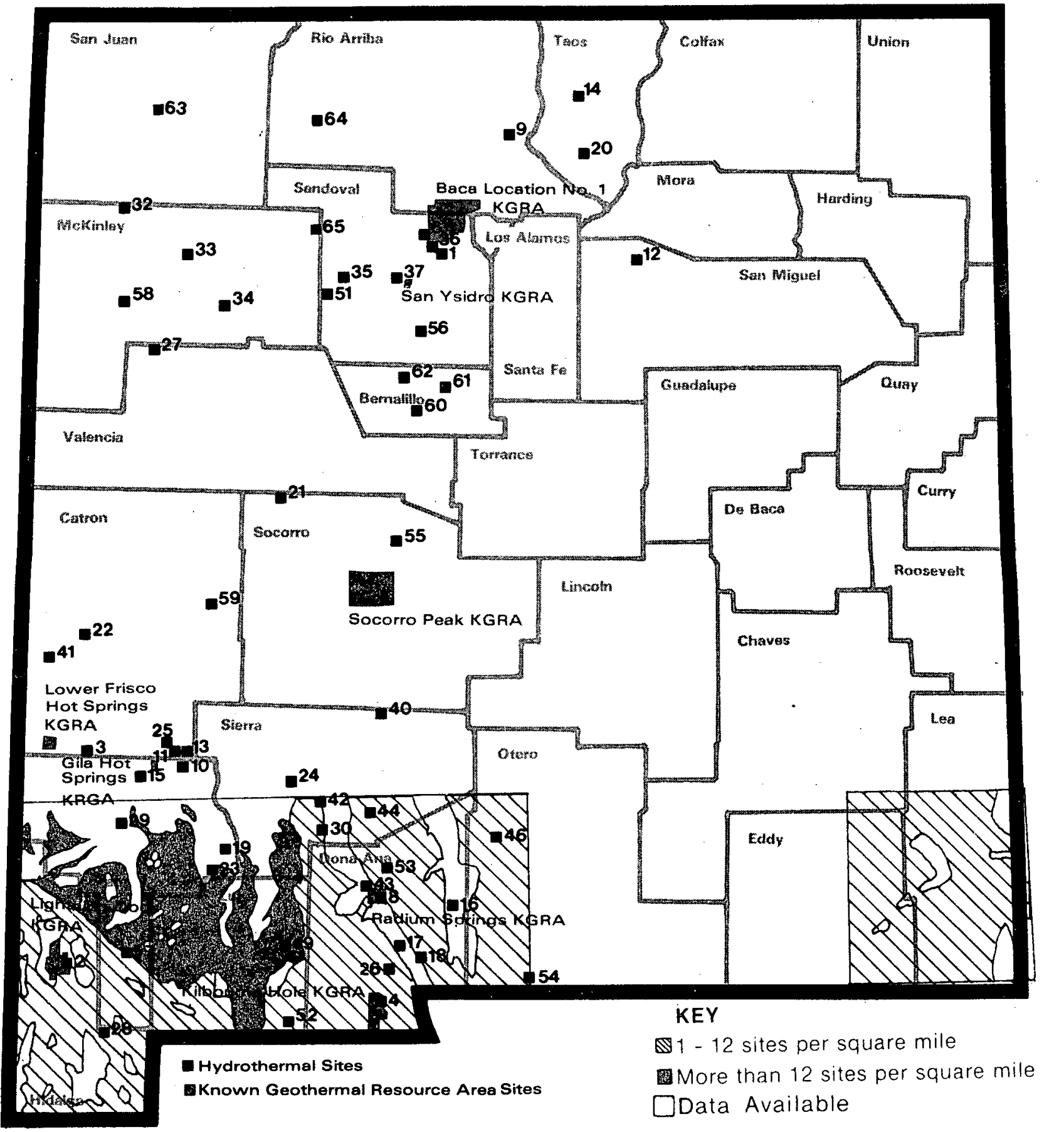

Figure 42. Predicted density óf archaeological sites (State Planning Division, 1978). 


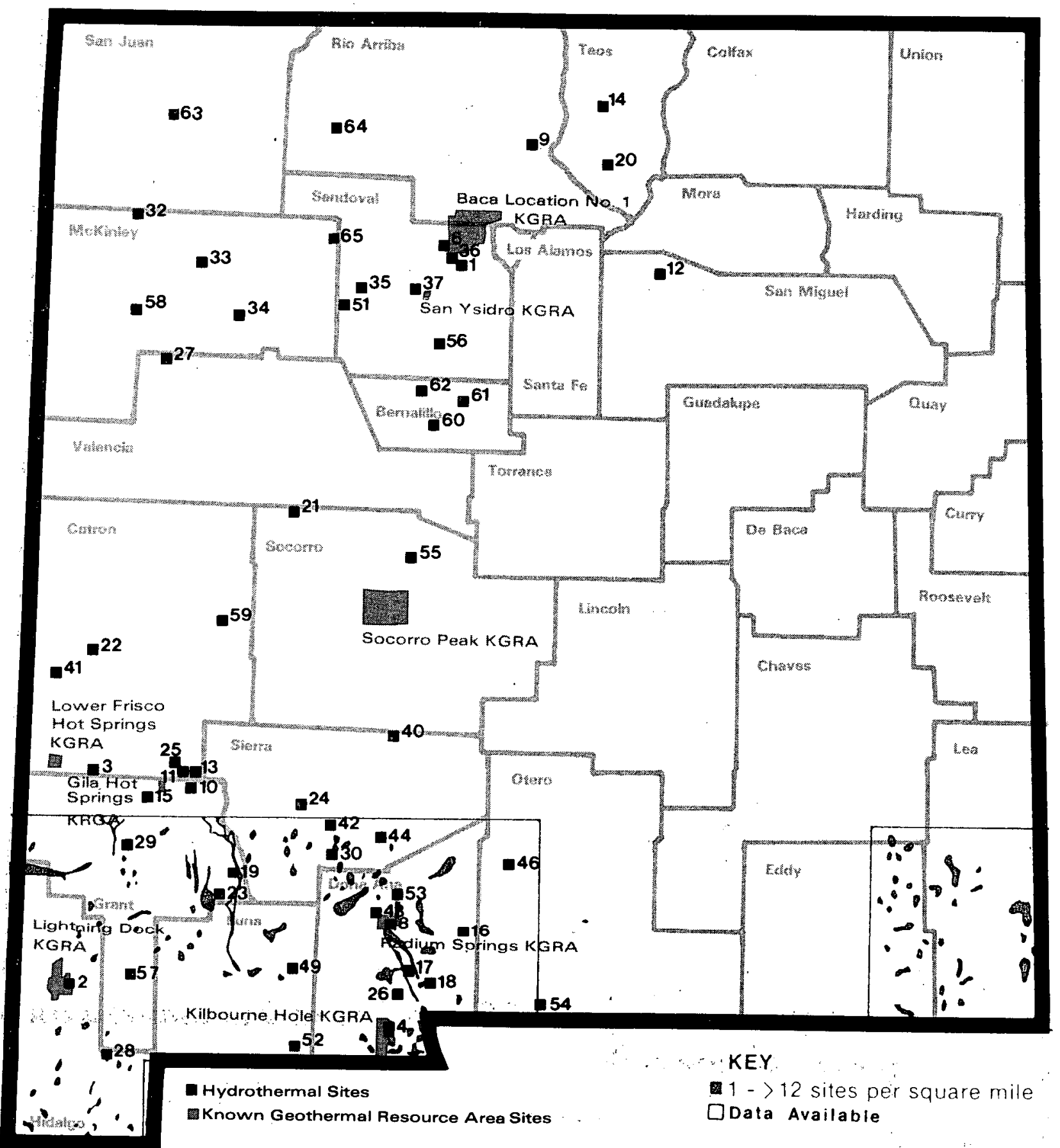

Figure 43. Known archaeological site densities (State Planning Division, 1978). 


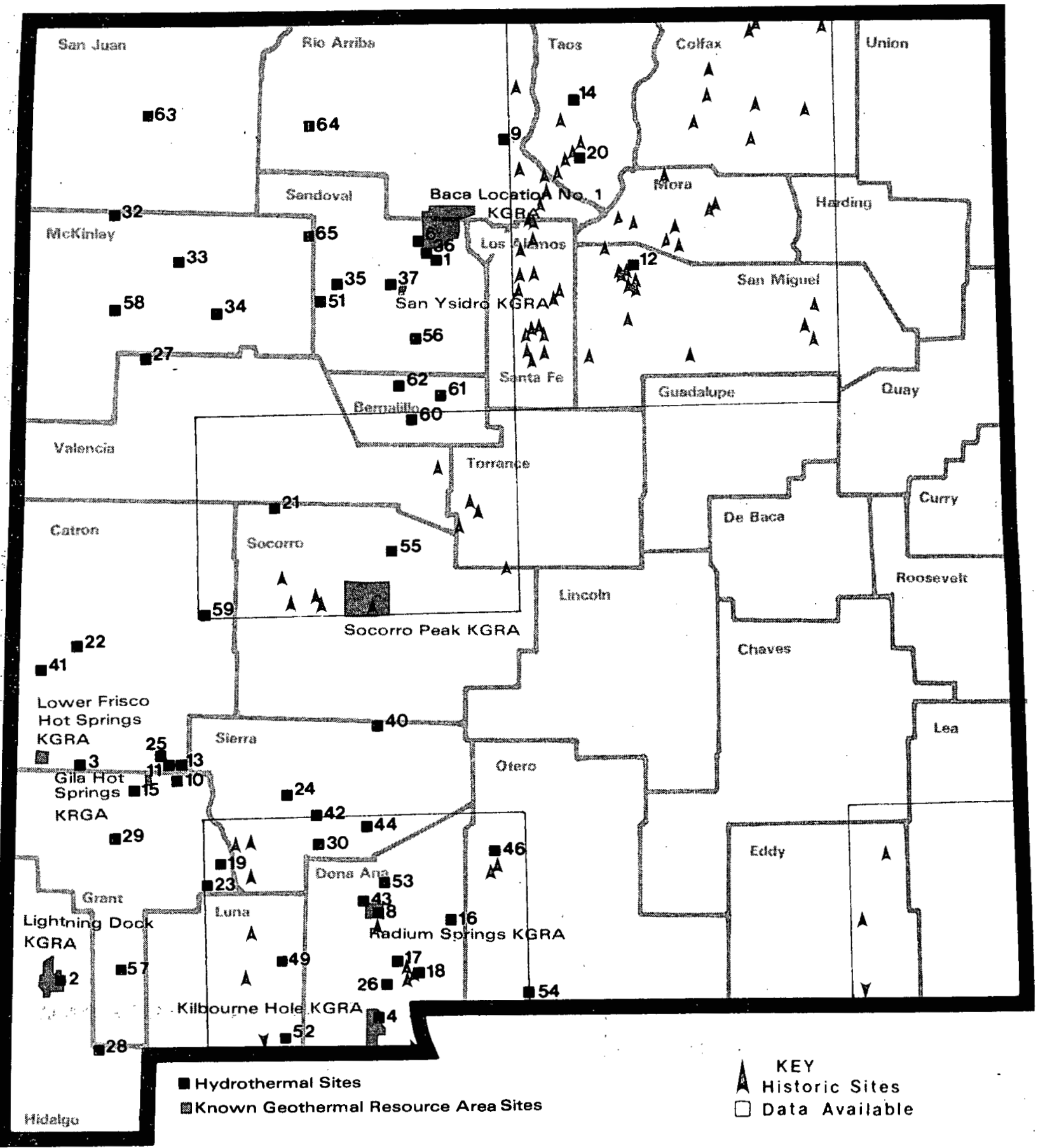

Figure 44. Registered historic sites (State Planning Division, 1978). 


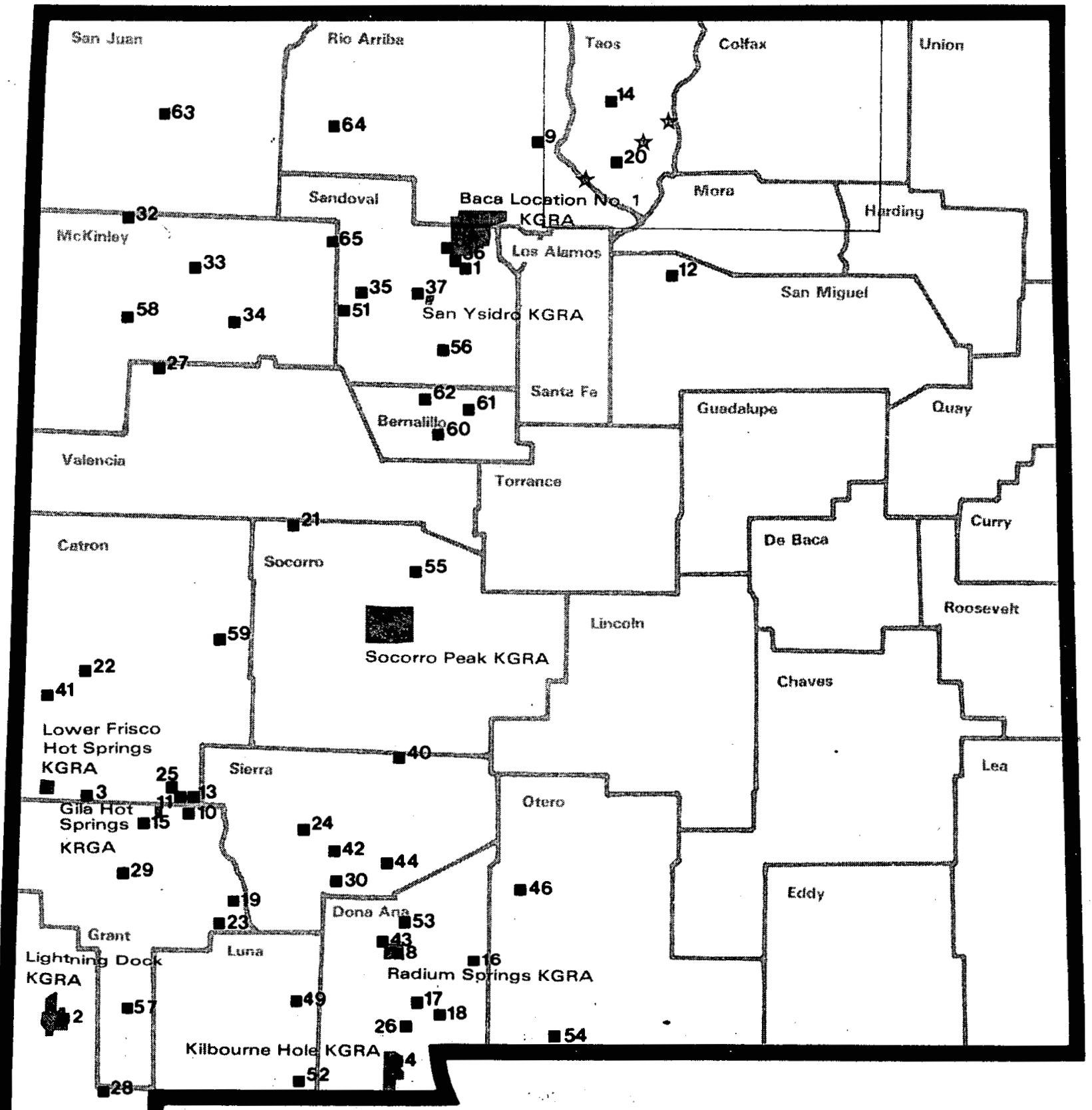

Hydrothermal Sites

Known Geothermal Resource Area Sites

KEY

Religious Shrines

$\square$ Data Available

Figure 45. Religious shrines (State Planning Division, 1978). 
Planning Division are: of public record. . Literature searches will provide some level of detajl on archaeology sites for site-specific development plans.

Because of the limited amount of publjc data, it is difficult to assess its value to geothermal developers. One might generally assume that if a previous study has not covered the precise area considered for geothermal development, the existing data may be of little use if the area is known to have a high concentration of sites. A survey of subsites in which disturbances are planned within a development could adequately establish data.

\subsubsection{Recreation}

An increasing population often demands increased recreation facilities. If no new facilities are needed, then the increased impacts on existing facilities must be considered. If long-tern predictions include a population increase due to geothermal development, the community must consider the effects on recreation in the area. On the otherhand, geothermal facilities, particularly those utilizing direct heat, may not increase the population at all.

\subsubsection{Description and Measurement}

A number of problems will be associated with recreational development if geothermal commercialization causes an area's population to grow and new recreational facilities are needed. If a community does not have the economic resources to develop a recreational area then outside funding must be sought. If sufficient funds are available for development, the cost of maintenance of new or existing facilities must be considered. This maintenance will include combating recreation pollution.

In a study on the recreational pollution in the Sandia Mountains (Fisk et al., 1977) the high priority pollutions (according to the public interviewed) include litter, wildlife harrassment, fire control and prevention, crowding, esthetics and noise. Others of jmportance were trash, garbage, sewage, soil compaction, vegetation destruction, erosion and water siltation. Low priority impacts were vehicle emissions, dust, rock removal and picnic-fire smoke. If these impacts are not checked, the recreational area will be destroyed. Existing state park and monument facilities are shown in Figure 46. The only wild and scenic river currently designated in New Mexico is in Taos County with two geothermal sites in the nearby area (Figure 47). The state also has extensive National Park and National Forest properties available for recreation. 


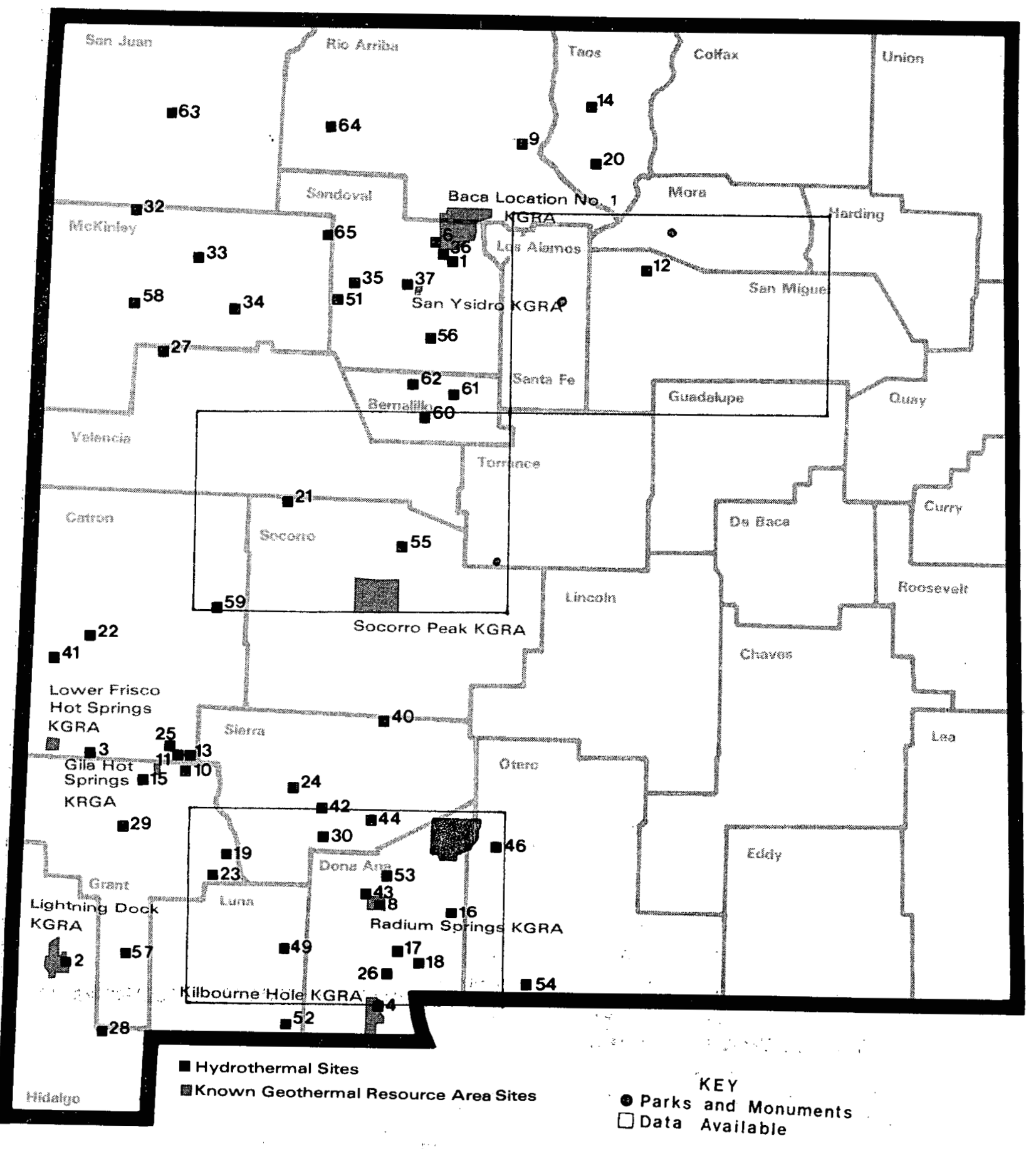

Figure 46. Parks and monuments (State Planning Division, 1978). 


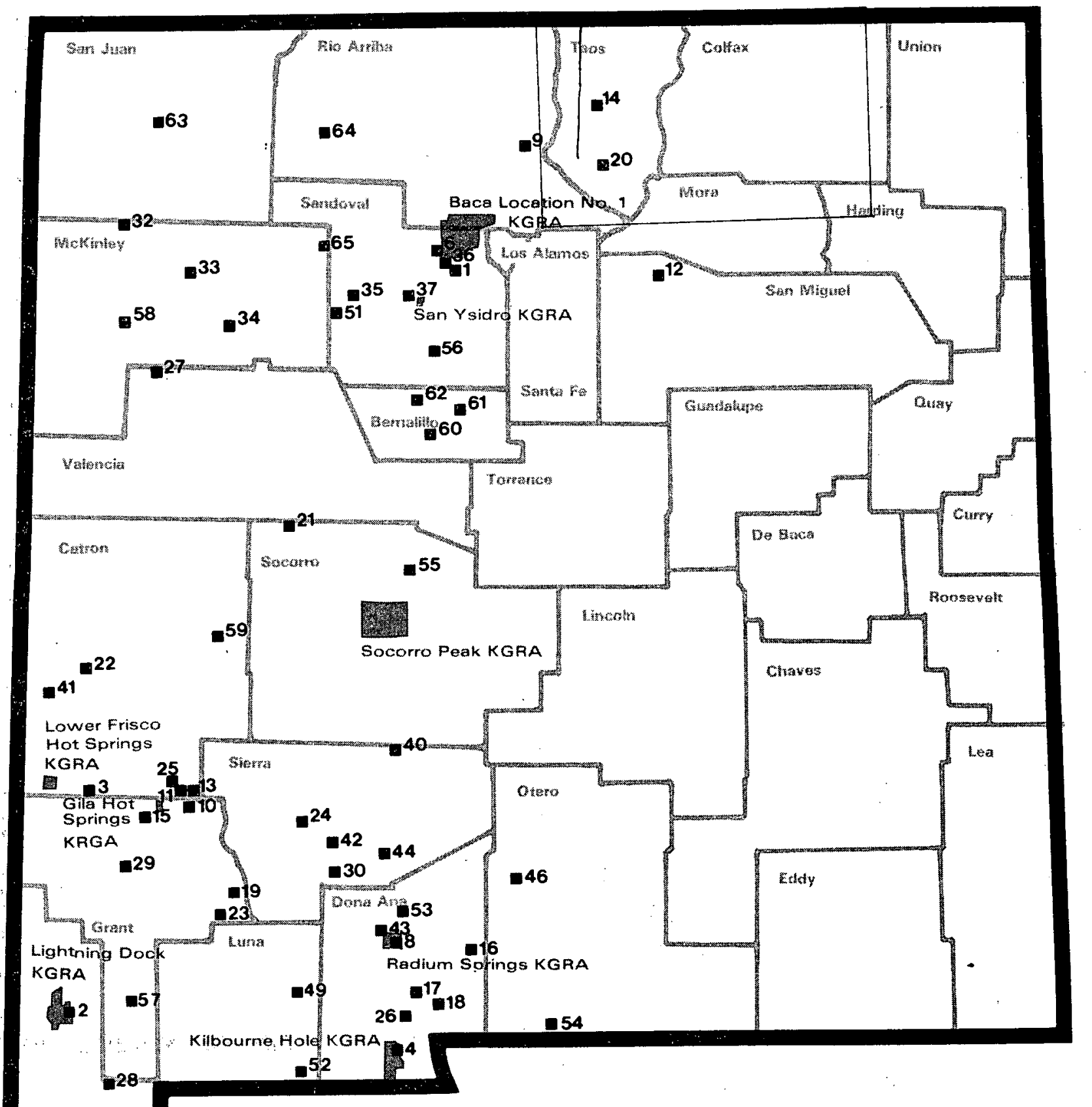

aydrothermal Sites

Whategna

Known Geothermal Resource Area Sites

$$
\text { KEY }
$$

- Wild and Scenic River

$\square$ Data Available

Figure 47. Wild and scenic rivers (State Planning Division, 1978): 


\subsubsection{Current Monitoring Activities}

Probably the only monitoring of the environment that occurs in or near recreational areas are those set up by the agency in charge of the recreation area, or those set up by the state or federal agencies for monitoring environmental impacts for some other reason. Another monitoring device are complaints by users, which may serve to inform the responsible persons of at least the grossest forms of pollution present.

\subsubsection{Accuracy of Baseline Data}

Baseline data on the status and availability of recreation areas in the state is complete and accurate. Measuring the effect of increasing an area's population based solely on geothermal development and commercialization is a bit more difficult. New Mexico's rural and urban areas will continue to grow in population, but this growth is more related to its position as a "sun belt" state and its increasing importance as an energy producing state (i.e., of oil, gas, and coal for exportation). Separating this general growth from that caused solely by geothermal energy growth may be impossible in most areas of the state. The only clear separation would occur where new industries utilizing geothermal energy employed an imported population (not'indigious to the area-possibly New Mexicans from other parts of the state). Population increases that occur during geothermal facility construction are likely to be temporary in nature (a short-term impact).

\subsubsection{Land Use}

One of the most important socioeconomic impacts will be on land use and land use planning. Another aspect of land use associated with geothermal development and facilities construction includes the attempt to alleviate potential environmental impacts from facility construction. This effort must be a community/developer joint effort. The major impact on land use will probably not occur because of the geothermal development, but because of the need for land to accommodate the population increases. In any case, geothermal developments should be compatible with any existing regional, state or local land use planning.

\subsubsection{Description and Measurement}

Undoubtedly the most difficult problem to resolve in the area of land use will be the development of priorities that placate the demands of al1 users; agricultural interests, mining interests, geothermal developers, etc. would all be requesting first priority on land use. A possible solution to this problem is land use planning. However, since much of this planning is based on tenuous principles, a development of priorities may be difficult to obtain. 
Impartial judgement of priorities would possibly serve to alleviate these political problems and attempt to resolve the true issues confronted by land use. These issues include minimizing environmental impacts and maximizing economic returns on a state-wide of community-based level.

Existing land uses are illustrated in the following series of figures from data available through the State Planning Office (1978). Areas of potential (and predicted) growth are shown in Figure 48. This growth is not necessarily related to geothermal development, but may be related to the increase in other energy development activities. Figure 49 shows existing irrigated agricultural lands. Figure 50 identifies areas without fresh water aquifers, which are therefore, unlikely areas for either agricultural or urban development. Mineral occurrences are displayed in Figure 51. Various upward turns in the economics of mining and processing minerals, particularly uranium and coal, will cause a predictable growth in populations and increase pressures for modifying existing land uses (ie. from agriculture to urban). Primary and secondary range land are shown in Figure 52. The locations of commercial timber industries are noted on Figure 53. Both of these land uses will possibly compete with geothermal development within the mountainous areas of New Mexico, although they may be very compatible with the use of geothermal energy facilities in these areas, since the geothermal facility would retire a relatively small amount of range or timberland.

\subsubsection{Current Monitoring Activities}

Land use monitoring is done by many departments and agencies. The New Mexico State University Agricultural Experiment Station monitors irrigated and non-irrigated farm lands. The $0 i 1$ and Gas Commission regulates the areas with extensive oil and gas development. The State Engineers Office keeps records on areas where land use is dependent on water use, e.g., land irrigated from underground water sources. The State Planning Division of the Department of Finance and Administration is monitoring land use in its Critical Areas Study (1979).

\subsubsection{Accuracy of Baseline Data}

Land use data that is available is quite accurate and up-to-date. The conspicuous absence of data stems from the non-existance of regional comprehensive land use planning efforts. Outside of city limits, few planning structures exist. The closest institution for accomplishing this type of planning are the Council of Government units, one in each of the state planning divisions of the state. 


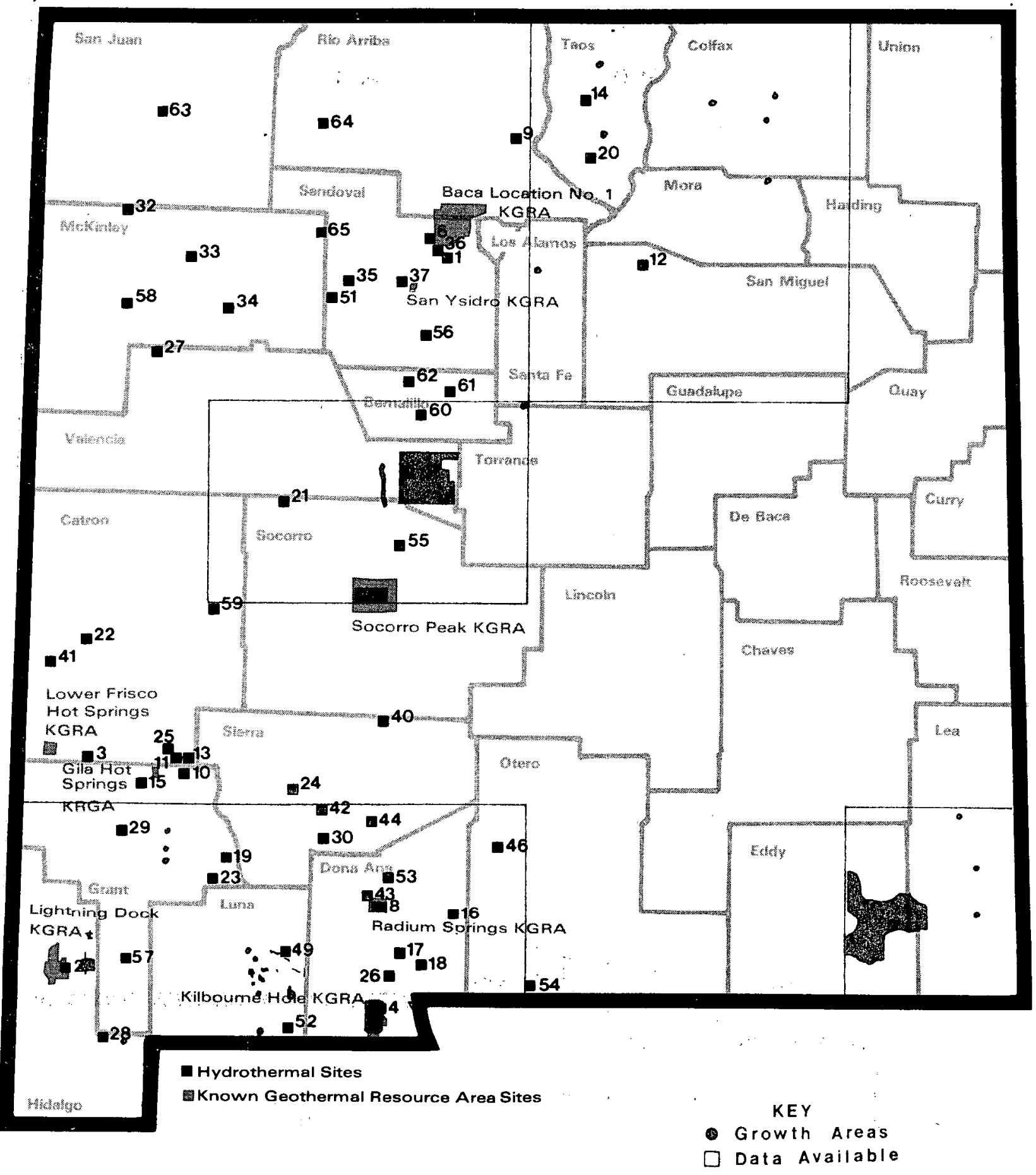

Figure 48. Potential growth areas (State Planning Division, 1978). 


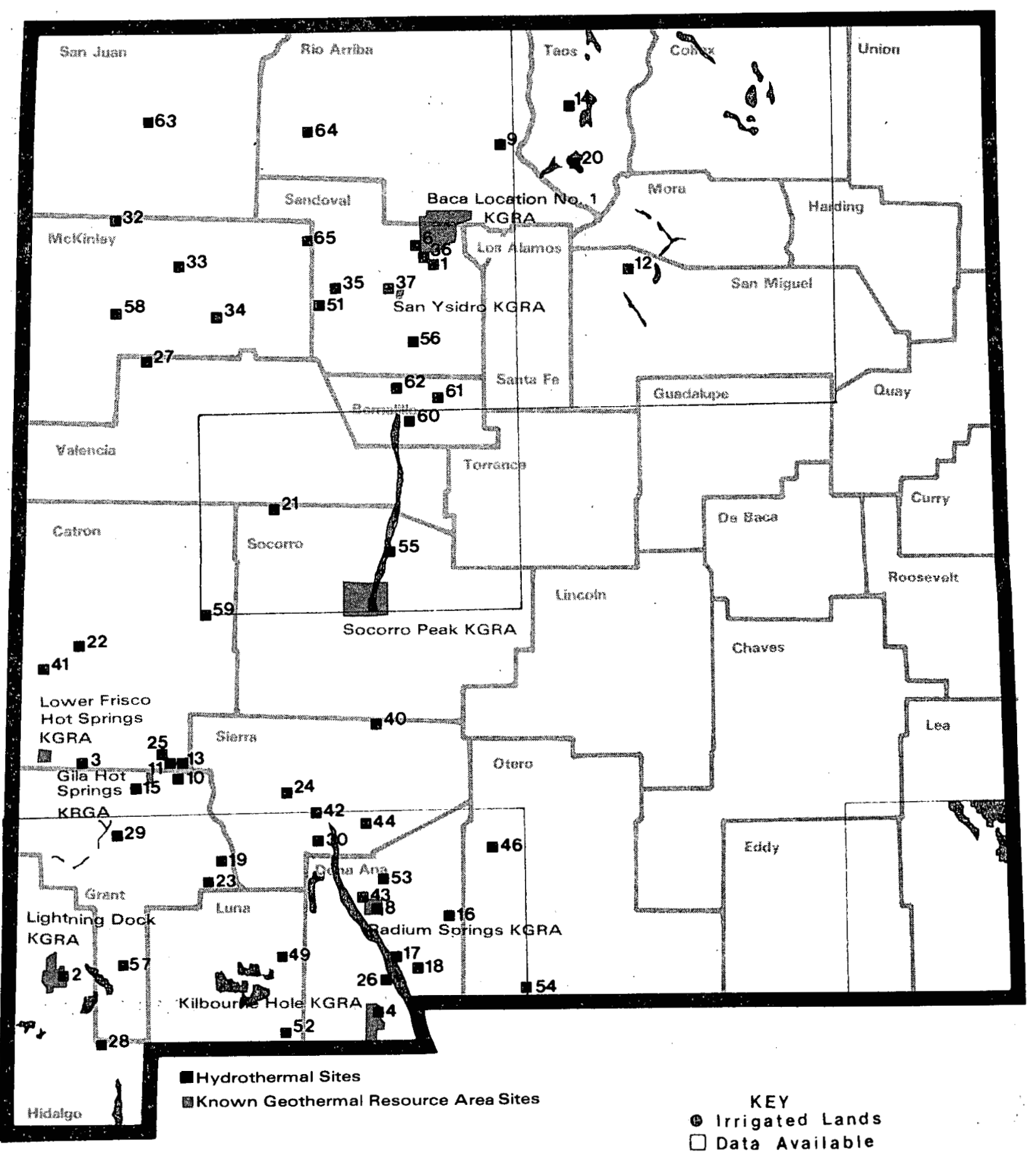

Figure 49. Existing irrigated agricultural lands (State Planning Division, 1978). 


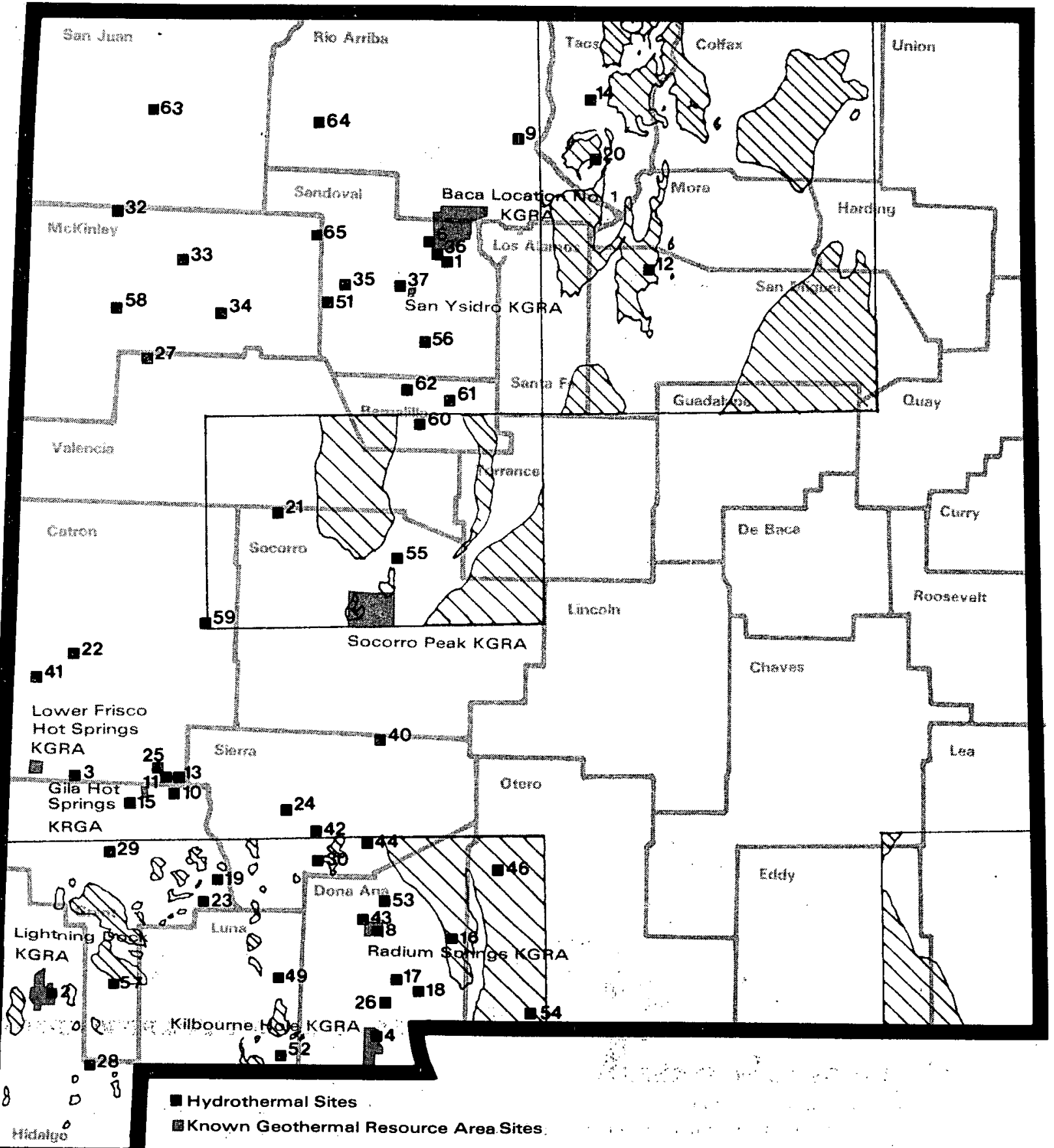

KEY

Without Fresh Water

Data Available

Figure 50. Areas without fresh water aquifers (State Planning office, 1978). 


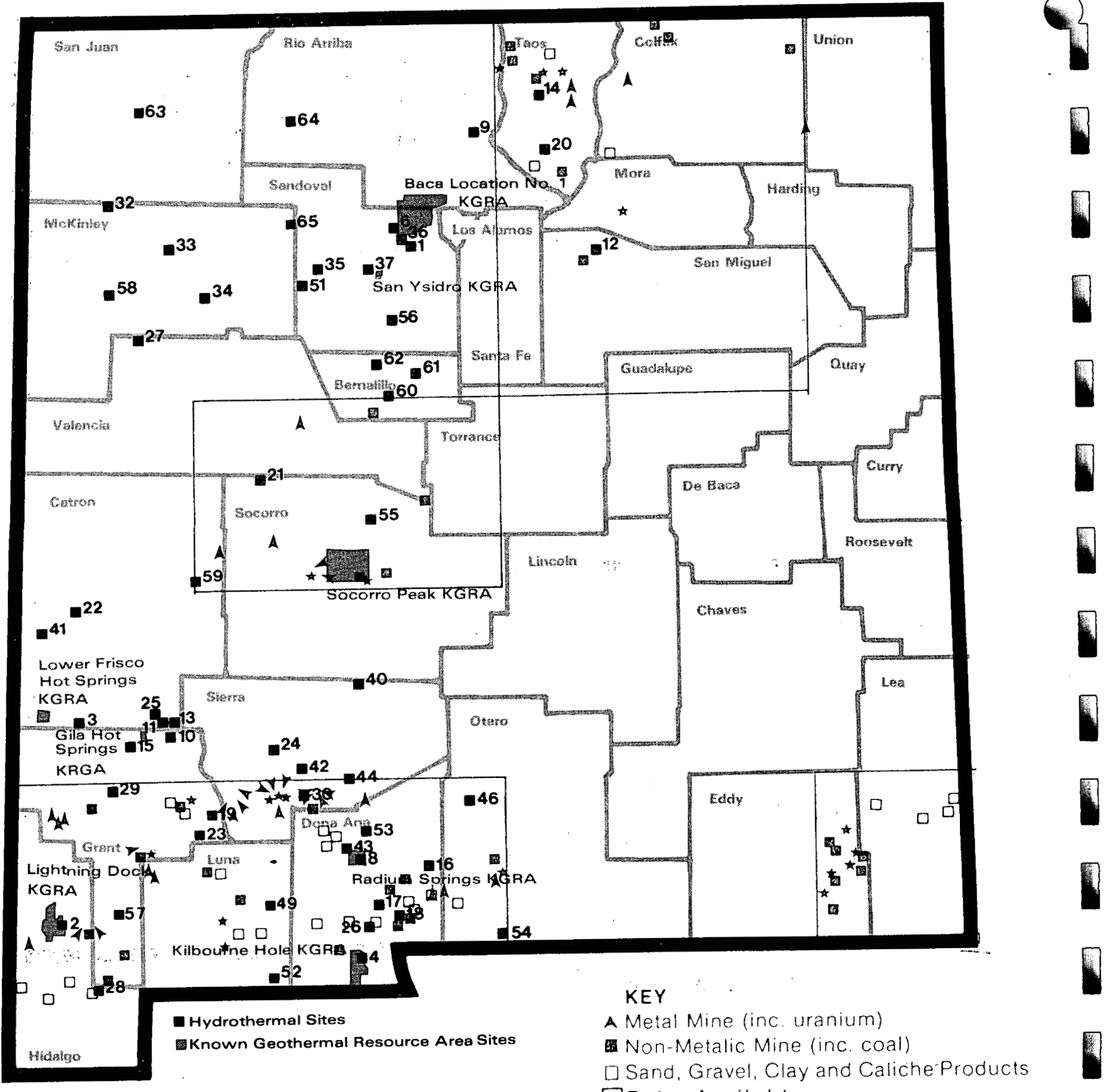

$\square$ Data Available

Figure 51. Mineral occurrences (State Planning office, 1978). 


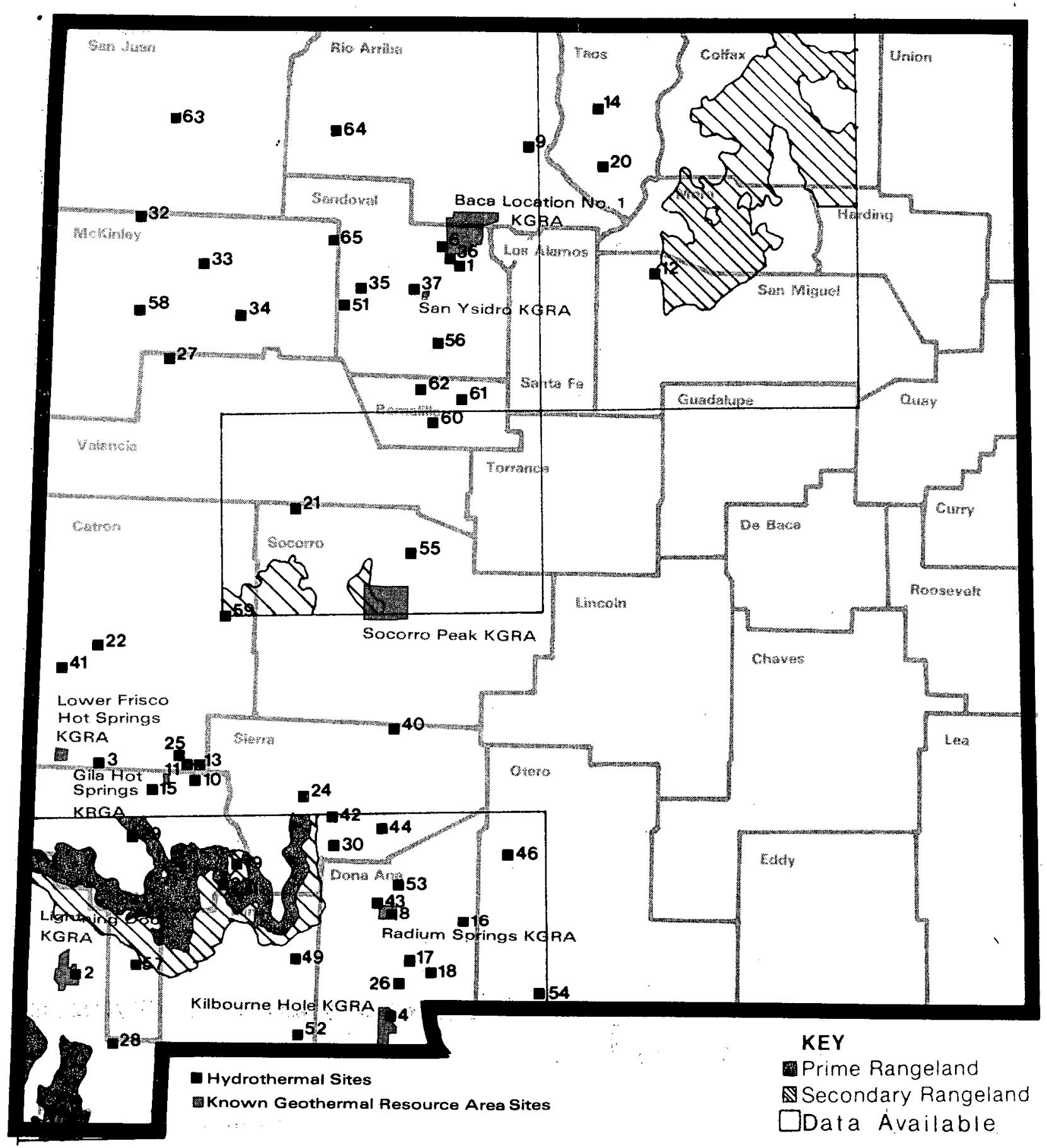

Figure 52. Prime and secondary range land (State Planning Division, 1978). 


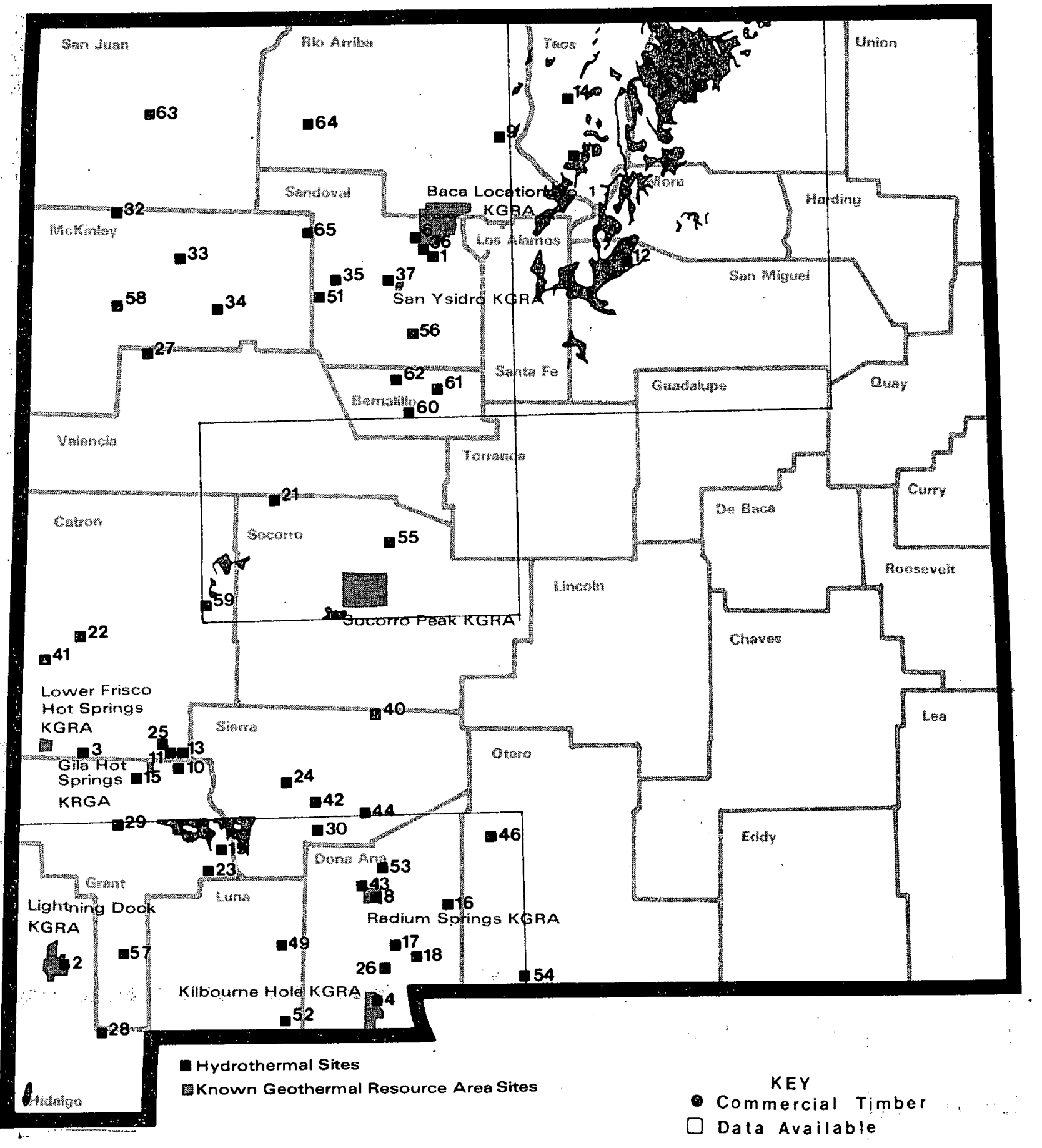

Figure 53. Commercial timber industry locations (State Planning
Division, 1978). 


\subsection{PREDICTED ENVIRONMENTAL IMPACTS}

Environmental impacts that may occur with the development of geothermal energy in New Mexico are divided into two groups: 1) short-term impacts, or those generally associated with exploration, development and construction phases; and 2) long-term impacts, or those generally associated with plant or facility operations. Where the degree of impact differs, these two groups will be further organized into those impacts associated with the technologies of electrical generation and those associated with the technologies of direct heat applications.

It should be noted that, since this report deals with a wide variety of geothermal resource sites and the potential of many different technological applications not yet proposed for any one site, this discussion of environmental impacts does not imply the degree of an impact will be the same in all sites or developments. Further, it should be realized that the State of New Mexico will continue to need electrical generation facilities and space heating and cooling in the future as well as the present for the well-being of its citizens. The environmental impacts of geothermal development should be balanced against those environmental impacts that would be associated with providing electricity and space heating and cooling from other energy

- sources, including the traditional fuels of natural gas, butane, propane, oil, and coal as well as newly developing energy sources of solar, nuclear, wind, and various synthetic fuels.

\subsection{Geophysical Impacts}

The impacts from geothermal development that could occur in the physica1 environment are man-induced seismicity and subsidence, and soil modification.

\section{1 .1 Short-Term Impacts}

A potentially major short-term impact is soil modification by compaction from the transportation of heavy equipment and by increased soil erosion from the construction of roads, drill sites, plants, facilities, and transportation (electrical lines and heat pipes) systems. The degree of impact is likely to be greater with the development of electrical generation facilities and large-tract district heating systems than for small direct heat applications (residential, commercial or industrial). This impact, where necessary, can be mitigated significantly by careful planning of site locations, and the construction of erosion control structures, and revegetation.

Accidental spills of drilling muds can impact soils, biota, and water quality. In this context (geophysical), if a serious spill would occur, it could modify the composition of surface soils. However, this potential impact can be mitigated by proper construction of mud containment areas. The size of the well field and the chemical makeup 
of the drilling mud would determine the degree of impact in both electrical generation and direct heat developments. The use of drilling muds are, of course, unique to oil, gas, water and geothermal field development.

Drilling activities on unstable slopes should be minimized where soil and slope composition may be suceptable to landslides.

\subsubsection{Long-Term Impacts}

The most severe impact to the physical environment, if occuring on any large scale, would be that of man-induced seismic activity caused by the movement of fluids and rock strata under pressure from either withdrawal or injection of geothermal fluids. The principles of rock mechanics are as yet not we1l understood, and it is difficult to determine in existing geothermal fields whether seismic activity that has been recorded is a result of better monitoring or changes in the geothermal reservoir. Baseline data on seismic activity in the state is not adequate over geologic time to determine if new activity is in response to geothermal development. There have been only three occurrences of seismic activity greater than 4.0 on the Richter scale in the 15 year history of the seismic recording network.

Injection of fluid into porous media has resulted in induced seismicity in two cases, both in Colorado--one at Rangeley, one at the Rocky Mountain Arsenal near Denver (Healey, et al., 1968; Raleigh, et a1., 1976). In both cases, fluid was injected to the formation at formation face pressures well above the pressure at which the rock fractured (fracture pressure), and large quantities of fluid were injected. At Rangeley, experiments with injection pressure showed that the earthquakes would occur when injection pressure was above a certain threshold, and would cease below that pressure. In both cases; the mechanism is believed to be dilatation of the porous rock (increase of interstitial pore pressure to the level at which rock grains floated apart) and opening of fractures and fault zones in the rock mass by the injected water. These phenomena decreased the rigidity of the rock, mass substantially. In the presence of seismic stress, this resulted in movement along the faults and resulting seismicity (Crow, pers. comm., 1980).

Many billions of barrels of oil and gas formation water have been injected into both the producing and disposal reservoirs in the major oil-producing states. Texas, Loujsiana, and California officials report that there is no reported instance of induced seismicity as the result of injection in their states. This says only that there has been no significant seismicity; that is, no one has complained of it. These states all restrict the pressure at which fluid can be injected. The limit is $0.8 \mathrm{psi} /$ foot of depth (hydrostatic is approximately $0.45 \mathrm{psi} / \mathrm{ft}$ of depth, and lithostatic about 1 psi/ft depth). This pressure is measured at the formation face. The reason this works is that most reservoir rocks require pressure in excess of this amount to cause fracturing. Clearly, the Colorado experience indicates that the rule of thumb doesn't always work. Perhaps a more 
conservative practice would be to limit injection to a few hundred psi above ambient at the formation face or to reduce pressure if fracturing occurs. In the Imperial Valley, the operators stopped injection when the pressure at the wellhead rose to 300 psi--considerably less at the formation face--and indeed found that scale and sludge had plugged up the formation (Crow, pers. comm., 1980).

Land subsidence, caused by fluid withdrawal from the geothermal reservoir without replacement, could be an impact of geothermal development. The degree of impact is likely to be greater in large well fields used for electrical generation facilities and large-tract district heating systems, than for individual direct heat applications.

Land surface subsidence is in the last analysis a function of decrease in reservoir pressure of the producing formation. The subsidence results from translation of compaction is the direct result of reservoir pressure change. Control of reservoir pressure means control of subsidence. Reservoir pressure can be controlled by injection of fluid back to the reservoir; thus fluid injection controls reservoir compaction and subsidence. Compaction is of two kinds: recoverable and nonrecoverable. Recoverable subsidence occurs between the grains of the reservoir rock--usually sand or limestone; essentially it is an elastic phenomena. Repressuring the reservoir returns it to its former state. Nonrecoverable compaction occurs in clays--within the reservoir and in the rocks above and below it. Essentially it is the result of dewatering the clays, which are originally saturated with fluid. Once the water is out of the clay, there is no returning it to original state. Oil field practice--unfortunately undocumented in published material--is to reduce the reservoir pressure slightly below the original by production, then to inject fluid to sustain this pressure. This procedure limits that subsidence to small amounts. It has been successful at East Wilmington oil field in California. This is the eastward extension of the old Wilmington field, where there was as much as 27 feet of subsidence locally. The East Wilmington extension has seen very little subsidence, according to ray source (Crow, pers. comm., 1980).

The severity of the impact must be measured in terms of disruptions to roads, pipe lines and transmission corridors, irrigation ditches, and buildings. If the drop is gradual or over a wide area, the impact might go unnoticed. Such subsidence may be occurring in areas where water is "mined" for irrigation and in oil and gas fields. Since no baseline data is available, it should be important to monitor this possible physical modification in the first large well field developments in the state, to establish whether this impact is significant. This activity and its impact is thought to be mitigated by the use of reinjection wells to return the geothermal fluids to the reservoir.

The important thing about subsidence is the sensitivity of the region to it: if the land use is affected by a small amount of subsidence (gravity-flow irrigation, wetlands, housing) then the area is sensitive. If, on the other hand, the land use is not sensitive (grazing, dryland farming, mountainous terrain) then much subsidence 
can be accepted without significant environmental effect. It is important to make a determination of potential sensitivity before setting up a subsidence monitoring effort. The level of the monitoring effort can be tailored to the sensitivity. For example, the Imperial Valley and the Gulf Coast (geopressured resource) are generally sensitive to subsidence. The Geyers and Roosevelt Hot Springs are not; probably the Baca is not, either (though Felix Miera, LASL, says his working group was worried about some nearby lakes) (Crow, pers. comm., 1.980).

Contamination of soils at solid waste disposal sites can be another long-term impact of geothermal development. Again, the degree of impact is dependent on the amount of solid waste produced by the facility (the larger the facility, the greater the potential waste), and it is also influenced by the chemical composition of the geothermal fluids. Fluids relatively free of toxic substances will create less hazardous solid waste problems. Some recovery of substances may be economically feasible, thus reducing the problem of solid wastes. Proper disposal handling and issuance of solid waste site permits are mitigating procedures for this impact source. Geothermal fluids with acceptably low amounts of potentially toxic materials can be used in "cascading" applications, including agricultural uses.

Soil erosion in transmission line corridors and heat pipe lanes can be an impact, but mitigating measures for revegetation and natural succession will reduce the significance of this problem. The greater the area of vegetation disturbance, the greater the degree of impact.

\subsection{Water Impacts}

The impacts of geothermal development that could occur in association with water in New Mexico are those related to the diversion of water from another usage (or the perception of potential diversion) and potential degredation of water quality.

\subsubsection{Short-Term Impacts}

The establishment of adequate and lawful water rights is the most significant of water quantity issues. In the arid Southwest, water is a most important commodity. The technology to be employed in a particular geothermal resource area and the amount of energy product--electricity, heat or cooling--will determine the degree of impact. This issue is considered short-term, since it must be resolved prior to the construction and operation of the facility and the granting of various regulatory permits. Once it is settled, if the quantity needs of the facility have been adequately projected, the long-term impact will be known in advance. Disputed socioeconomic water issues will be discussed in that section $(6.6)$.

Accidental well blowouts, surface spills of drilling muds, and accidental loss of drilling mud in the subsurface rocks may impact the quality of surface and groundwaters in the vicinity and have the 
potential of mixing waters from different aquifers. The degree of impact will depend on the quantity and chemical makeup of the errant drilling muds or geothermal fluids. The effects of these accidents are likely to be minimal (in terms of duration and distance from the well that is affected). Mitigating procedures to avoid surface spills and blowouts are known by experienced drillers and regulatory agencies. We11s can be repaired or plugged, if necessary. Contamination by loss of drilling mud in the surface rocks will be reduced by the water's normal circulation in a short period of time.

At any time in the history of a given geothermal well. There is the potential for downhole leakage from well casing or channelling in the cement into potable aquifers. Deterioration of potable water quality could occur from such leakage. This could be detected by periodic cement bond and casing continuity. logging, and mitigated by conducting the necessary repairs.

The soil erosion impact described in the previous section (Geophysical 6.1.1) may cause siltation in the surface water near construction activity sites. The degree of impact, of course, is likely to be greater with large-scale facilities than with individual direct heat applications. Mitigating procedures to prevent continued soil erosion will also reduce or eliminate excess siltation.

\subsubsection{Long-Term Impacts}

Consumptive use of water, primarily in electrical generation facilities, is the most significant water quantity impact of geothermal development. Assuming that water rights issues have been solved, this impact is predictable over time. The real question here is the location of the generating facility in relation to available water and existing water rights, rather than the quantity of water that will be used by an electrical generation plant. Conflict arises when geothermal resource areas are located in places where water is scarce or devoted to other uses (i.e., fishing streams, irrigation, bath houses), since the geothermal resource must be used where it is. The degree of impact from consumption use of water at the geothermal electrical power plant will vary with the unique circumstances of each site. It may, if the competition for water is great enough, be one of the most important impacts to consider for a particular geothermal development. Direct use geothermal applications will probably have little significant impact from consumptive use of water. Since the quality of geothermal waters varies considerably in New Mexico, one possible benefit of geothermal development may be the "rnining" of useful waters from closed aqui.fers, those not presently circulating in ground and surface water combinations. This may produce new water sources for New Mexico.

Another issue associated with solid waste storage related to soil contamination is the contamination or degregation of surface waters, through disposal site runoff, and groundwater, through disposal site seepage. In both cases, the degree of impact is dependent on the amount and chemical composition of the solid waste. The amount of 
waste is, of course, a function of the facility size and the type of technology being used. The larger the quantity of geothermal fluids being processed, the more solid waste that will be stored. The seriousness of health hazard presented also depends on the nature of the geothermal fluids. As previously stated, some geothermal water in the state is of better quality than some drinking water. The degree of impact of this possible source of water quality degregation will be very site-specific, and may be an important impact in certain locations.

A issue related to contamination of surface and ground waters from solid waste disposal sites is that of contamination from accidental spills at well sites, along pipelines, or at the plant or facility. In both situations, mitigating procedures can be used to reduce runoff to critical surface waters or retard such runoff to permit dilution with fresh water and reduce the impact. Siting of solid waste disposal sites with specific attention given to groundwater circulation can reduce the potential for serious impact of such contamination.

\subsection{Air Impacts}

The impacts of geothermal development that could occur in association with air quality in New Mexico are the emission of air contaminents-including hydrogen sulfide, visual degredation and fugitive dust.

\subsubsection{Short-Term Impacts}

The most significant short-term impact on air quality during geothermal exploration, well development and construction of facilities is the emission of air contaminents during the drilling and testing of wells. The degree of impact is likely to be greater for the development of electrical generation facilities, due to the higher temperatures and pressures in the geothermal reservoir. This, of course, would continue to be true for direct heat wells drilled into high temperature reservoirs $\left(150^{\circ} \mathrm{C}\right.$ or greater) where fluids may rise as steam allowing pollutants to comingle with air molecules rapidly. In lower temperature reservoirs, the fluids will probably remian as liquids, emitting fewer air pollutants at the surface. Hydrogen sulfide levels associated with a given reservoir cannot be predicted with certainty before reservoir testing. If the hydrogen sulfide level is low or nonexistant, there will be no impact. If the $\mathrm{H}_{2} \mathrm{~S}$ level is sufficient to result in significant ambient levels, impact will occur prior to capping the well and during well testing periods.

A second possible impact on air quality would be that of fugitive dust contamination caused by construction activities. It is exceedingly doubtful that this impact would have any significance over time, or that it would be greater in a geothermal development area than if the same area were undergoing any other construction activity. And 
considering the combination of dry weather and high winds generally prevalent in the state during certain seasons, the significance of such impact would be reduced if it occurred simultaneously with spring winds or similar ambient condition. The standard construction mitigation technique of watering down the area, where water is available, would reduce this impact. The degree of impact will vary with the season, the types of soils and vegetation in the area, and the amount of land surface under disturbance.

\subsubsection{Long-Term Impact}

The most important impact of geothermal development on air quality stems from contaminent emissions from the venting of we1ls in the well field, and the hydrogen sulfide abatement processes and cooling tower emissions at the electrical generation facility. The degree of impact is further influenced by the chemical makeup of geothermal fluids, the type of hydrogen sulfide abatement equipment, and cooling tower construction planned for a particular facility. Current technology in abatement systems and cooling tower design can significantly reduce this impact. (The Stretford process of hydrogen sulfide abatement, for instance, may reduce emissions of $\mathrm{H}_{2} \mathrm{~S}$ by $60-95 \%$.)

Baseline data within the state is only available for pollutants of carbon monoxide, sulfur dioxide, nitrogen dioxide, photochemical oxidents (ozone) and total suspended particulates. Although the state has standards for arsenic, beryllium, boron, hydrogen sulfide, hydrocarbons, heavy metals, total reduced sulfur, mercury, ethane and fugitive dust, no units now monitor these contaminants throughout the state. Spot monitoring of problem areas may be insufficient for new geothermal facilities. It is important that the initial geothermal electrical generating facilities have comprehensive monitoring programs for all possible pollutants that are identified as being present in the geothermal fluids. Results from the initial demonstration projects may be sufficiently conclusive to reduce the effort needed for later facilities. It is equally important that the state develop the capacity (in equipment and staff) to monitor the current regulations on a continuing basis as related to geothermal development. Of particular interest in cooling tower operations is the distribution, of toxic materials and particulate materials transported in water vapor through cooling tower drift. Predicting the pattern of the drift is the subject of several modelling programs currently being developed in the United States. Models most appropriate to New Mexico are those that simulate complex mountainous terrain, since most of our geothemal sites are either in mountainous areas or along the valley floors near the mountains. The importance of being able to predict the distribution pattern is determined by the nature of pollutants being distributed in this manner and what lies in the path of distribution. The location of the geothermal resource site also determines the allowable increases for air pollution above a present baseline air quality level under provisions in the Clean Air Act of 1977, with development in Class II and III areas having a greater latitude of air quality standards than those of a Class I areas. 
Most direct heat applications involve "closed loop" handling of geothermal fluids, limiting the exposure of fluids to the atmosphere. This reduces the degree of impact on air quality at such facilities, regardless of the water quality. In addition, if the geothermal fluids used at a given direct heat facility have a low level of pollutants, there will be no air quality problems of the facility.

Visual degradation is another impact of geothermal (and other types of energy) development. At geothermal sites, visual degradation takes the form of steam plumes from well venting or cooling tower operation mostly associated with electrical generation facilities. The degree of impact is related to the location of the facility. Under the Clean Air Act of 1977 Significant Deterioration and Visability Protection amendment, visual targets, such as a mountain range, are considered more important in scenic areas than in urban areas. Class I areas are defined as international parks, wilderness areas which exceed 5,000 acres and national parks which exceed 6,000 acres. New Mexico has nine such areas in the state, five of which are located in the general vicinity of geothermal resource areas. Visual degradation impacts would be more important to these areas, and probably less significant to other geotherma1 areas.

\subsection{Noise Impacts}

By definition, noise is considered "unwanted" sound. Although no positive impacts are associated with noise, if it is not perceived as unwanted by either regulation, medical research or public opinion, then no pollution has occurred. In the case of regulation, the impact must be mitigated or an infraction has been committed. In the cases of medical research and public opinion, mitigation is not required, but for the sake of community harmony, the developer of a geothermal site might do well to consider this action.

\subsubsection{Short-Term Impacts}

The impact of noise pollution in geothernal development stems from drilling and well testing activity. The degree of impact will be influenced by the type of drilling operation (air vs. drilling mud), the type of well testing activity (steam venting vs. pumping water for drawdown tests), the amount of sound emitted, and the type of perceivers to be impacted. Short-term drilling and well testing activities can use mitigating procedures for sound dampening. The most significant impact would be felt by the development workers at the site, where OSHA regulations would apply. Only one community, Albuquerque, currently has any noise abatement regulations that would come into conflict with any type of geothermal development, and those regulations could be met with proper procedures. Therefore, the short-term impact of noise pollution is probably not very significant to the state as a whole or to individual geothermal sites under development. 


\subsubsection{Long-Term Impacts}

Point-source noise from well venting and turbine operation in electrical generation facilities are the main contributors to impact during plant operation. The most serious impact of this nature will be on employees at the plant, since noise decreases over distance from the source. OSHA standards can be met by using various mitigating procedures (i.e., land buffers, ear plugs, etc.). This impact will be greater with electrical generating facilities, and probably non-existant with direct heat applications. The degree is also influenced by the distance of the operation from towns and cities. Besides the physical and psychological effects of noise pollution on humans, interference with life cycles of wild animals can occur. Since this source of pollution can be controlled effectively on the plant site with appropriate use of mitigating procedures, this impact is not beleived likely to be very significant in the development of New Mexico's geothermal resources.

\subsection{Biotic Impacts}

Biotic impacts are site and technology specific. They are secondary, that is, the result of changes in the environment caused by other types of impacts, such as physical modifications, water quantity and quality changes, air quality changes and changes in noise levels and land use.

\section{5 .1 Short-Term Impacts}

The most direct short-term impact on the biota at a geothermal site is the immediate loss of habitat through disturbance in exploration, development and construction on the site. The degree of impact will vary with the degree of disturbance, and will be greater in electrical generating facilities and large district heating well fields than in smaller-surfaced site development. The effects of this impact can be mitigated by careful planning for site development to reduce the total area disturbed and eliminate destruction of critical habitat unique to the area. Disruption of non-critical habitat is not likely to have an effect on the floral and fuana populations nearby. The disruption of existing habitat may have a positive impact by providing species diversity in an area where it did not exist-a bonus for encouraging wildife populations but a detractor for growing mature Ponderosa pine stands.

Accidental spills, blowouts, and excessive erosion can cause deterioration of ground and surface waters and silting of surface waters, which, if serious in nature, will cause temporary loss of habitat and reduce both biotic populations and biotic diversity in the immediate area. The degree of this impact will vary with the severity of the problem and the nature of the geothermal fluids dispersed in this uncontrolled manner. 


\subsubsection{Long-Term Impacts}

Changes in land use patterns resulting from new industries locating in the area to use new energy supplies and bringing an influx of human population will result in loss of habitat in the area. This may cause interference with migratory routes. The degree of impact will be greatest with electrical generating facilities and large-scale industrial heating/cooling direct use applications. Regional planning can reduce the effect of this type of impact on the immediate area.

Changes in air quality, particularly deposition of airborne toxic elements and particulate waste, can impact the flora of the region. The degree of impact becomes significant if threatened and endangered species or field crops are involved.

Changes in water quantity from drawdown of groundwater aquifers can cause changes in stream systems leading to a negative impact on riparian habitat and the development of exotic aquatic habitats in sumps. Decreasing water quality, caused by erosion or chemical emissions, will cause a decrease in the biotic diversity of the area. If mitigating procedures control the primary impacts to soils, vegetation, air and water, then the biotic impacts will be lessened.

\subsection{Socioeconomic Impacts}

Socioeconomic changes may be issues, rather than impacts. Changes may be determined by discussion and prior resolution, rather than being the direct consequence of changes in the physical environmental elements (ie. air, water, physical structures and biota). For the purpose of this discussion, short-term impacts will be those associated with the preconstruction activities at a geothermal site, and long-term impacts will be those associated with construction and operation of a geothermal facility of any type.

\subsubsection{Short-Term Impacts}

Infringement on religious beliefs can be an important impact in any of the phases of geothermal development. Recognition of the affected cultures and cultural areas by the developer is mandatory prior to the initiation of any site activity. Mitigation through consultation with representatives of the cultures to be affected can be effective in reducing this impact. Compliance with the American Indian Religious Freedom Act is required if the geothermal resource area is adjacent to Indian lands or sacred areas.

Destruction of archaeological and historical sites is a prime impact in New Mexico. The developer must be in compliance with laws and regulations concerning these sites and is required to carry out adequate site surveys in advance of site-specific activities. Consultation with the Museum of New Mexico and adequate pre-planning of development can mitigate this impact. 
Another significant impact is site-related employment. Will the exploration and development activities utilize indigenous or imported personnel? What is the role of the Employment Security Commission in obtaining workers for the project? How will nearby communities be affected by employment opportunities, if indigenous workers are to be used, or by impacts on housing, schools, transportation routes and public services, if imported personnel are being used?

Site-specific geothermal exploration and development will involve the hauling of drilling and field equipment to the site from main highways. This may occur over rural roads. If so, what will the impact of this activity be on these roads and the communities adjacent to those roads? What mitigating procedures can be used (will the state widen the road, for example)?

\subsubsection{Long-Term Impacts}

The following impacts or issues are offered as a checklist for developers, communities, and state and federal governmental units who are all involved together in the socioeconomic impacts of any major development, including geothermal development, in a particular part of the state.

1. New legal definitions of ownership of the geothermal resource: Who owns the resource? If the State owns the water, who owns the heat? Who has control of taxing, law enforcement, etc. on federal lands and other non-state and private lands? Conflicts in these issues need to be resolved in the courts and the state legislature, and may in fact, retard geothermal development in parts of the state.

2. Infringement on religious beliefs: Did the resolution of short-term impacts adequately solve issues for long-term facility operations?

3. Cultural impacts: Input must be made by affected groups at each step of resource development. What are the self-determined life styles of the area residents? What is the proper mechanism for determining who represents what cultural groups in the area. A1I cultures and subcultures must be represented in the overall process.

4. Aesthetics: Identify problems and perceived interference with aesthetics in the area. Attempt to mitigate these in the planning effort. Be mindful of the sensitivity to cultural differences in New Mexico.

5. Employment during construction and facilities operation: Will the work force be indigenous (a positive impact) or imported (both positive and negative impact depending on the size of the work force)? What is the role of the Employment Security Commission?

6. Regional resources management or land use management: Will multiple use concepts be used? Will the carrying capacity of the land 
be coordinated (air, land, water, community services)? Will the area be allowed growth? Who determines this? What is the real socioeconomic data base? What kind of coordinating units exist? What should exist? What will exist? Will the Community Assistance Council be involved? What will the impact of this development be on the communities involved?

7. Growth management: In determining the development of an area, degrees of action should be selected-no action, low action, medium action, high action. Who should determine this? What will be the impact of this growth on recreation facilities and governmental services?

8. Spinoff use of energy for industrial development: Co-generation and other technology should be considered. What will the auxilliary development due to community growth be? Should the community work towards localized energy self-sufficiency? What technologies are economically feasible?

9. Energy requirements and identification of the final consumer: The California power users or in-state consumers? Determine energy and power needs prior to the project. Identify end user and potential "bumping" which might occur as energy resources dwindle.

10. Government services: What are the cost vs. benefits? Do the entities involved have the ability to raise the necessary monies? What federal money sources are available?

11. Taxing base: A full spectrum analysis of the taxing alternatives should be developed prior to developing a geothermal resource. What will be the impact on local tax structures and revenues? What are the existing and proposed tax incentives?

12. Transportation: Who will pay for improving roads to the sites? What impact will improved roads have on rural areas? Consider power lines and heat distribution pipes as a part of the transportation impact. What right-of-way problems exists?

13. Archaeological and heritage preservation from hydrogen sulfide deterioration: Is this being considered in the planning? What management is there for protection of sites? What technology is available to minimize damage?

14. Public information and education: There must be a sincere effort to disseminate information at the conception of the project to a11 the impacted communities. A public relations effort should be made to inform and educate the general public. Who is responsible for this effort--the developer, the government? Which government?

15. Impact of geothermal development on tourism: Will this be a positive or negative impact? Tourism is a substantial industry in the state. Does the state want to bill itself as a leader in geothermal energy production to attract tourist? What are the economics of development and tourism? 
16. Government's ability to regulate and enforce existing laws: The governmental entities that will be involved in the development and operation of a geothermal facility should be identified. There should be an analysis of their staffing needs to meet additional demands of regulations and enforcement associated with this development. There should be provision made for change in agency operations, if needed. 


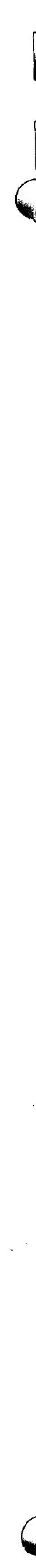

158 


\subsection{RECOMMENDATIONS AND CONCLUSION}

The recommendations and conclusions of this study include the input of the 60-person Environmental Overview Workshop held in Albuquerque, New Mexico, September 7 and 8, 1979 and input of the project staff. In a state of over one million people, it is unlikely that every individuals viewpoint is reflected here, but this document represents a starting point for discussion of the environmental impacts that will be significant in the development of the state's geothermal resources.

\subsection{Ranking of Environmental Impacts}

Environmental impacts associated with geothermal development in New Mexico are ranked as "high" and "low" priority for general geothermal development. Individual impacts and issues may be more or less important to the development of specific geothermal sites and the type of development (electrical generation, district space heat, individual space heat, agricultural or industrial processing) planned for the site. Comprehensive analyses of existing baseline data for both the site and technology to be developed in an individual project early in the development process will determine the ranking of environmental impacts appropriate to the project that is planned.

\subsubsection{High Priority Impacts}

These potential environmental impacts will be the most significant to the development of geothermal energy in New Mexico. The degree of importance of each impact will vary with the character of each resource area and the mitigation actions taken prior to and during development.

Water. The environmenta1 impacts of geothermal development associated with water are those related to the diversion of water from another existing or potential use and the changing of water quality. In the arid Southwest, water is a most important element of man's surviva1. Both short-term (Section 6.2.1) and 1ong-term (Section 6.2.2) impacts affecting water quantity and quality must be considered important to the development of all types of geothermal technologies, from the estab1ishment of new bath houses on a small scale to the establishment of major electrical generation facilities. The degree of impact will, of course, vary with the locale, size and type of development.

Air. Disintegration of air quality, if occurring as a result of geothermal development, is also of great importance in New Mexico. Long-term impacts (Section 6.3.2) will be more significant than short-term impacts (Section 6.3.1), and the uncontrolled release of contaminants is of greater importance than visual degredation, except in the portions of the state perceived as being "most scenic." With the application of current geothermal technologies, air-associated 
impacts are more important in the development of electrical generation facilities using steam-flash technologies than in direct heat applications. At the moment, projects in low temperature geothermal resource areas are not believed likely to encounter significant air pollution impacts, based on initial data from existing thermal wells and springs and direct heat technologies.

Socioeconomic. The impact of geothermal development on socioeconomic parameters will vary considerably with location of and the size and type of planned development. Both short-term (Section 6.6.1) and long-term (Section 6.6.2) impacts need to be considered at the initiation of resource exploration activities that are intended to lead to immediate geothermal resource development. Involvement of all the communities that will be impacted by planned development needs to occur continuously in the development process.

\subsubsection{Low Priority Impacts}

These potential environmental impacts are, in general, the least significant to the development of geothermal energy in New Mexico. In specific geothermal projects, individual exceptions may be made in relation to unique conditions of the geothermal site.

Biotic. Biotic environmental impacts occur as a result of changes in the environment caused by other types of impacts. If a project has met all current regulations (Section 4.0) and the primary impacts of air quality and water quality and quantity and vegetation have been satisfactorily resolved, biotic impacts associated with geothermal development (Sections 6.5.1 and 6.5.2) will be minimal in most geothermal developments. Unique site characteristics related to threatened and endangered species may increase the importance of these impacts on development in a specific geothermal resource site; im such cases, biotic impacts will have a high priority.

Geophysical. Environmental impacts associated with geothermal development and the physical parameters of the environment are those of man-induced seismicity, subsidence and soil modification. Longterm impacts (Section 6.1.2) will be more important than shortterm impacts (Section 6.1.1). Induced seismic activity is a significant issue in areas of the state that show a history of natural seismic activity. Seismicity in an area that has no natural activity, however, is likely to be more noticaed than in an area with natural seismic activity. Subsidence related solely to geothermal development will be important to high population areas and transportation corridors (highways, pipe and transmission lines, irrigation systems). Soil contamination may be more significant than soil modification, although proper engineering will mitigate both.

Noise. The impact of noise pollution on geothermal development is perhaps the least significant by its very definition of "unwanted sound." Impacts of this nature become important when the public perceives that sufficient sound disturbances are occurring as a direct 
result of a specific geothermal project. The importance of this impact will vary greatly with the size and type of geothermal development project. Because most geothermal activity will produce low levels of noise, and because many of the prospective geothermal areas are remote from human habitation, impacts are unlikely to be significant.

\subsection{Recommendations for Specific Actions to be Taken in Evaluating the Significance of Environmental Impacts Associated with Geothermal Development}

These recommendations are made in the interest of providing sufficient information for decision-making and for providing the necessary advance planning and coordination of industry, government, and the people involved in geothermal development projects throughout New Mexico.

\subsubsection{Geophysical}

\subsubsection{Research and Data Acquisition}

1. Research is needed to determine the effects of reinjection of geothermal fluids on subsidence and seismic activity in high and low temperature reservoirs.

2. In initial geothermal projects within areas of seismic activity, adequate seismic monitoring networks should be established and monitored to determine if induced seismicity is occurring, and, if so, how significant it is. Continued activity of this sort with additional geothermal projects will depend on the earlier findings.

3. Subsidence data is needed for initial large-scale geothermal developments (ie., electrical generation or district heat well fields) if subsidence could create economic problems in that specific location.

4. If on1y Agricultural Experiment Station soils data is available at a given geothermal site, soil surveys may be necessary for well and plant sites, and road and transmission corridor sitings. Engineering geologic studies may be needed in areas with unstable rock and soil conditions for large geothermal facilities.

\subsubsection{Regulations and New Legislation}

1. Legislative action should be taken to give authority to the appropriate agencies (perhaps the Geology Division of the Energy and Minerals Department or the New Mexico Bureau of Mines) to develop guidelines for maximum acceptable levels of phenomena such as subsidence and induced seismicity. 
2. Standardization of baseline data measurements should be developed by the Energy and Minerals Department, the New Mexico Bureau of Mines and the New Mexico Energy Institute at New Mexico State University and other interested agencies and groups.

\section{2 .2 Water}

\subsubsection{Research and Data Acquisition}

1. Site-specific baseline data from test wells in the geothermal resource area is needed for determination of chemical composition, temperatures and quantities of geothermal waters for the production reservoir in order to determine the potential severity of environmental impacts on air quality and water supplies and quality, as well as, the associated biotic impacts. This data should be collected during exploration and well field development.

2. Future hydrological reports of potential geothermal reservoirs should identify the methodology used in assessing the resource, and address the associated weaknesses in estimating reservoir temperatures, volumes, dissolved constituents and toxic substances.

3. Research needs to be conducted on changes, if any, in water quality, reservoir temperature and pressure, ground and surface waters and other related parameters associated with the developinent of geothermal resources in areas where the hydrology is not well documented to determine if these are connections between geothermal reservoirs and groundwater reservoirs, and if so, what effect such connections might have on water quality.

\subsubsection{Regulations and New Legislation}

1. The appropriate regulatory agency should take all possible means to prevent the potential contamination of local surface waters by spillage or seepage by geothermal fluids, even to the extent of requiring the divertion of streams, provided such action does not prove detrimental to existing water rights.

2. A state procedure for identifying the adequacy of data for determining environmental impacts should be developed by the appropriate state agencies (ie., the Environmental Improvement Division and the Water Research Institute) for institutions, industries or municipalities to follow in initiating geothermal development.

3. New regulations need to be developed concerning the reinjection of geothermal fluids and potential contamination of other aquifers from both injection and downhole well leakage. 


\section{2 .3 Air}

\subsubsection{Research and Data Acquisition}

1. Baseline data on air quality is necessary and should reflect undisturbed (pre-exploration) conditions. This may require the use of similar, but undisturbed, areas if data collection begins after much of the initial exploration and development activities occur.

2. It is necessary for the state regulatory agency to evaluate the adequacy of available baseline data in the vicinity of a planned geothermal project to determine if further data collection activities are necessary.

3. There is a need for the development of a self-contained (self-powered) type of air monitoring equipment to alleviate the problems associated with having the placement of such equipment related to the location of power sources.

4. Research should develop sophisticated modeling techniques to predict the environmental effects of toxic emissions on air quality in rough terrain locations. Such models should be verified to determine if their predictions are valid in New Mexico.

\subsubsection{Regulations and New Legislation}

1. There is a need to expand the existing ambient air monitoring system to acquire baseline data on the air pollutants of arsenic, beryllium, boron, hydrogen sulfide, hydrocarbons, heavy metals, total reduced sulfur, mercury, methane, ethane and fugitive dust in areas where large-scale geothermal development involving potential air emissions is anticipated. This expansion is necessary for the enforcement of current air quality standards.

2. Technology for point-source pollutant monitoring for the specific pollutants in item one needs to be developed.

3. Regulatory agencies need to evaluate the long-term (1ifetime of the facility) environmental impacts relative to air pollution and geothermal development in the broader context of pollution associated with the use of other energy forms for the same purpose (i.e., electrical generation by petroleum fuels, coal, nuclear, solar vs. geothermal and direct heat from synfuels, coal, wood, etc. vs. geothermal). This broader context evaluation is equally important to consumption for any purpose in the state and is essential to the long-term protection of air quality.

4. Since the majority of air quality problems are associated with cooling tower, operation, as the main exit point for effluents, the state's regulatory agencies and geothermal development industries must work together to insure that all options are considered (ie., wet-dry 
towers, use of binary systems for generation, and improved control technology).

\section{2 .4 Noise}

\subsubsection{Research and Data Acquisition}

1. If noise pollution is determined to have an important impact in site-specific geothermal development, there is a need for the collection of baseline data prior to development. This data should reflect undisturbed conditions and may require the use of similar undisturbed areas if initial development activities are occurring.

\subsubsection{Regulations and New Legislation}

1. There is a need for source-specific noise regulations in portions of New Mexico where geothermal and other kinds of development are perceived to potentially create conflict (ie., in significant natural areas or within populations centers). Such regulations must consider existing ambient noise levels.

\subsubsection{Biota}

\subsubsection{Research and Data Acquisition}

1. There should be a state-wide listing of geothermal sites that have not been biotically surveyed, cross referenced with current sources of information

2. Research needs to be conducted to obtain inventories of the biotic systems in New Mexico in geothermal resource areas to aid in the assessment of potential impacts of geothermal development.

3. Additional funding should be sought for the completion of a biotic data information system which would survey and monitor geothermal sites.

4. Monitoring activities should be conducted at geothermal development sites to assess on-going impacts of such development.

5. Research should be conducted on the mitigation of biotic impacts associated with geothermal development.

\subsubsection{Regulations and New Legislation}

1. There should be a coordination of state and federal agency efforts in sharing of biotic data. This should prevent data overlap and redundancy in data collection. 


\subsubsection{Socioeconomic}

\subsubsection{Research and Data Acquisition.}

1. A predictive capability for the socioeconomic parameters associated with energy development in New Mexico should be interated into the Energy Managment Information System currently under construction at the New Mexico Energy and Minerals Department. This tool should be used in developing future environmental impact assessments.

2. Baseline data needed for archeological and historical site location is needed within the projected disturbed surface areas of a geothermal development project. The intensity of such baseline surveys is dependent on the predicted and known archeological/historical site density in the specific geothermal area.

\subsubsection{Regulations and Legislation}

1. The planning of community services and recreational facilities to meet future population growth in specific areas of New Mexico needs to be considered as a whole, of which geothermal development may play a part. The real issue is energy availability vs. population growth. Formal or informal regional planning groups (composed of such units as the Council of Governments, citizen groups, local tribal councils, city and county governments, and federal agencies, particularly those that are land stewards in the region) should be outlining a program now to meet or limit projected growth. Planned geothermal project could then be fit into existing regional efforts.

\subsection{General Summary Comments}

In conclusion, the environmental impacts and their relative importance to geothermal development in New Mexico that are presented in this document are as varied as the quality of the individual geothermal resource and the type of technology applied in a particular geothermal development project. Appendix $F$ presents an overview of the availability of baseline environmental data for development within currently identified geothermal sites. Impacts likely to be of high importance include water availability and quality, changes in air quality and effects on the socioeconomic status of each area. Impacts likely to be of lesser importance include geophysical impacts, impacts on the biota and problems caused by noise. 
Adams, L. H. 1924. A physical source of heat in springs. Journal of Geography, 32:191 p.

Albee, H. F. 1968. Geologic map of the Munger Mountain Quadrangle, Teton and Lincoln Counties, Wyoming. U.S. Geological Survey $(G Q-705)$.

Allen, E. T. and A. L. Day. 1935. Hot springs of the Yellowstone National Park. Carnegie Institutional Publication 466:525 p.

American Association of Petroleum Geologists. 1975. Geothermal gradient map of Arizona and western New Mexico. Geotherma1 Survey of North America, American Association of Petroleum Geologists (Portfolio map area no. 18).

American Conference of Governmental Industrial Hygienists. 1976. Threshold limit values for chemical substances in workroom air adopted by American Conference of Governmental Industrial Hygienists for 1976. American Conference of Governmental Industrial Hygienists.

Anderson, D. N. and L. N. Axtel1 (eds). 1972. Geothermal overviews of the western United States. Geothermal Resources Council (Specia1 Report 1).

Anderson, W. 1970. Mineral springs and health resorts of California with a complete chemical analysis. The Bancroft Co., San Francisco, California.

Anspaugh, L. R. 1977. The geotherma1 environmental overview project. Lawrence Livermore Laboratory, University of California (UDIC-17632).

Armstrong, F. C. and E. R. Cressman. 1963. The Bannock thrust zone of southeastern Idaho. U.S. Geological Survey (Prof. Paper 374-J).

Ary, M. D. 1959. Geology of the eastern part of the Thermopolis and Lucerne anticlines, Hot Springs County, Wyoming. Master's Thesis, University of Wyoming, Laramie.

Atlantic Scientific. 1976. Environmental impact report, Ford Flat Geothermal Steam Area, Lake County, California. County of Lake Planning Department.

Augustin, L. A., W. N. Capener, L. B. Catlett, C. E. Eastman, J. R. Gray, B. C. Ives, M. E. Matthews and R. J. Supalla. 1977. Socio-economic impacts of coal mining communities in northwestern New Mexico. Surface Environment and Mining, Forest Service, U.S. Department of Agriculture. Agricultural Experiment Station at New Mexico State University (AES Bulletin 652). 
Aytmann, R. C. 1975. Environmental impact of a geothermal power plant. Science $187(4179)$.

Baca Environmental Impact Statement. 1979. Draft environmental impact statement for the geothermal demonstration program, $50 \mathrm{MW}$ power plant, Baca Ranch. U.S. Department of Energy (DOE/EIS-0049-D).

Baker, C. L. 1946. Geology of the northwestern Wind River Mountains. Geological Society of America Bulletin 57:565 p.

Barnett, P. R. and E. C. Mallory. 1971. Determination of minor elements in water by emission spectroscopy. Geological Survey (Techniques of water resources inventory, book 5, chapter A2).

Bartlett, A. B. 1925. Report on examination of mineral springs and hot water wells. Wyoming Geological Survey.

Bartley, A. B. 1926. The mineral hot springs of Wyoming. Wyoming Geologist's Office (Bulletin 16).

Battelle Pacific Northwest Laboratories. 1976. Removal of hydrogen sulfide from geothermal steam. Energy Research and Development Administration (Contract 非-45-1-1830).

Bazant, Z. P., S. Nemat-Nasser and H. Ohtsubo. 1976. Finite element solution of geothermal energy extraction. Proceedings of Stanford Geotherma1 Program Workshop, Stanford University.

Bechtel Corporation. 1977. Operation and maintenance of the East Mesa Test Site. U.S. Bureau of Reclamation (Contract 非4-06-300-2622).

Bechtel Corporation. 1977. Advanced design and economic considerations for commerical geothermal power plants at Heber and Niland, . California (SAN-1124-2).

Behrendt, J. C., B. L. Tibbetts, W. E. Bonini and P. M. Laving. 1968. A geophysical study in Grant Teton National Park and vicinity, Teton County, Wyoming, with sections on stratigraphy and structure. U.S. Geological Survey (Professional Paper 516-E:1-23).

Bel1, G.R. 1962. Design criteria for diatomite filters. Journal of the American Wastewater Association (Vol. 54).

Bel1, W. G. 1956. Tectonic setting of Happy Springs and nearby structures in the Sweetwater uplift area, central Wyoming. American Association of Petroleum Geologists, Rocky Mountain Section Geological Record.

Biehler, S. 1971. Gravity studies in the Imperial Valley, cooperative geological-geophysical-geochemical investigations of geothermal resources in the Imperial Valley area of California. University of California, Riverside.

Blackwe11, D. D. 1969. Heat-flow determinations in the northwestern United States. Journal of Geophysical Research 74(4):992-1007. 
Blackwe11, D. D. 1971. The thermal structure of the continental crust. p. 169-184. In Heacock, J. G. (ed). The structure and physical properties of the earth's crust. Geophysical Monograph Series 14, Washington, D.C.

Blair, A. G., J. W. Tester and J. J. Mortenson. 1976. LASL hot-dry-rock geothermal project, July 1975-June 1976. Los Alamos Scientific Laboratories (LA-6525-PR).

Bloomster, C. H. 1975. GEOCOST: A computer program for geothermal cost analysis. Battelle Corporation, Pacific Northwest Laboratories, (BNWL-1888).

Bloomster, C.H., L. L. Fassbender and C. L. McDonald. 1977. Geothernal energy potential for district and process heating applications in the U.S. An economic analysis. Battelle Corporation, Pacific Northwest Labs (BNWL-2311).

Bond, R. G. and C. P. Straub. 1973. Handbook for environmental contro1. Vo1. IV. Wastewater treatment and disposal. CRC Press, Cleveland, Ohio.

Boyer, S. E. 1932. Hot Springs State Park. S. E. Boyer and Co., Casper, Wyoming.

Brown, D. W. 1973. The potential for hot-dry-rock geothermal energy in the western U.S. Los Alamos Scientific Laboratories.

Brown, M. G., R. B. Duffield, C. L. B. Siciliano and M. C. Smith. 1979. Hot dry rock geothermal energy development program. Los Alamos Scientific Laboratories (LA-7807-HDR).

Brown, E., H. W. Skougstad, and M. J. Fishman. 1970. Methods for collection and analysis of water samples for dissolved minerais and gases. Geological Survey (Techniques of water resources inventory, book 5, chapter A1).

Bureau of Business and Economic Research. 1977. New Mexico Statis'tical Abstract. The University of New Mexico Press, Albuquerque.

Bureau of Reclamation. 1976. New Mexico water resources: assessment for planning purposes. United States Department of Interior.

Burk, C. A. 1952. The Bit Horn hot springs at Thermopolis, Wyoming. Wyoming Geological Association Guidebook, 7th Annual Field Conference.

Burma $0 i 1$ and Gas Company. 1975. Environmental impact report, Castle Rock Springs geothermal steam area, Lake County, California. Atlantis Scientific.

Bush, R. C. 1976. An overview of PG\&E's audible noise measurement program at The Geysers. Geotherma1 Environmental Seminar, 1976. 
Bush, R. C. 1977. Plant and equipment noise treatment. Proceedings of Pacific Coast Electrical Association and Engineering and Operation Conference.

California Department of Health. 1976. Guidelines for the preparation and content of noise elements of the general plan. Office of Noise Control. California Department of Health with Office of Planning and Research.

Callender, J., W. Elston, S. Kudo and W. Seager. 1979. Location of late Quaternary volcanic rocks, faults and major volcanic centers. Preliminary report to the New Mexico Energy Institute at New Mexico State University.

Callender, J., G. Landis, G. Jiracek, et al. 1976. Evaluation of geothermal potential of the basin and range province of New Mexico. New Mexico Energy Institute at New Mexico State University (NMEI 6).

Callender, J. and C. Swanberg. 1979. Deep sedimentary basins. Preliminary report to the New Mexico Energy Institute at New Mexico State University.

Carslaw, H. S. and J. C. Jaeger. 1959. Conduction of heat in solids. Oxford University Press, Ely House, London. 2nd edition.

Chapin, C. 1979. Geological investigation of the Socorro geothermal area. New Mexico Energy Institute at New Mexico State University (NMEI 26).

Chaturvedi, L. 1979a. Analysis of geological and geophysical logs of two geothermal exploration wells drilled on New Mexio State University Land. Prelimiary report to the New Mexico Energy Institute at New Mexico State University.

Chaturvedi, L. 1979b. Distribution of water, oil and gas wells having abnormally high bottom temperatures. Preliminary report to the New Mexico Energy Institute at New Mexico State University.

Chaturvedi, L., C. Keyes, et a1. 1979. Use of geothermal energy for desalination in New Mexico. New Mexico Energy Institute at New. Mexico State University (NMEI 42).

Chen, C. L. and R. P. Miele. 1977. Demineralization of sand-filtered secondary effluent by spiral wound reverse osmosis process. Environmental Protection Agency, (600/2-77-169).

Chen, C. L. and R. P. Miele. 1977. Wastewater demineralization by two-stage fixed bed ion exchange process. Environmental Protection Agency $(600 / 2-77-145)$.

Chen, C. L., H. H. Takenaka and R. P. Miele. 1975. Demineralization of wastewater by electrodialysis. Environmental Protection Agency $(600 / 2-75-047)$. 
City of Truth or Consequences. 1978. Geotherma1 space heating for the senior citizens' at Truth or Consequences. Proposal submitted to the Energy and Minerals Department, Santa Fe.

Clark, S. P., Jr. 1966. Handbook of physical constants. Geological Society of America, Inc., New York.

Collier, A. J. 1920. Oil in the warm springs and Hamilton domes, near Thermopolis, Wyoming. U.S. Geologica1 Survey (Bulletin 711-D).

Cosner, S. R. 1977. Geothermal brine data file. Lawrence Livermore Laboratories, University of California.

Cox, E. R. 1976. Water resources of northwestern Wyoming. U.S. Geological Survey (Hydrologic Atlas 558).

Crawford, J. G. 1940. Oil-field waters of Wyoming and their relation to geologic formations. American Association of Petroleum Geologists (Bulletin 24).

Cuellar, G. 1975. Behavior of silica in geothermal waste. Second UN Symposium on the Development and Utilization of Geothermal Resources. San Francisco, California. U.S. Government Printing Office. Washington, D.C.

Culp, R. L. and G. L. Culp. 1971. Advanced wastewater treatment. Litton Educational Publishers, Inc., New York.

Cunniff, et al. 1979. Geothermal potential applications for the Rocky Mountain Basin and Range Region, Draft Special Data Report, New Mexico Energy Institute at New Mexico State University (NMEI 10-6).

Cunniff, R. and C. Rao. 1979. Geothermal market penetration assessment for Colorado, New Mexico, Montana. New Mexico Energy Institute at New Mexico State University (NMEI 30-2).

Dalkey, N. 1969. The Delphi Method: An experimental study of group opinion (RAND R-5888-PR).

Dane, C. H. and G. O. Bachman. 1965. Geological map of New Mexico. New Mexico Bureau of Mines and Mineral Resources, Socorro.

Day, A. L. 1939. The hot spring problem. Geological Society of America Bulletin 50(3):317.

Decker, E. R. 1976. Geothermal resources, present and future demand for power and legislation in the State of Wyoming. Wyoming Geological Survey (Public Information Series).

Dellechaie, F. 1975. A hydro-chemical study of the south Santa Cruz Basin near Collidge, Arizona. Second UN Symposium on the Development and Use of Geothermal Resources. San Francisco, California. U.S. Government Printing Office. Washington, D. C. 
DiPippo, R. 1978. An introduction to electrical energy conversion systems for geothermal energy resources. Brown University Press, Providence.

Dodds, F. J., A. E. Johnson and W. C. Ham. 1975. Material and corrosion testing at The Geysers geothermal power plant. Second UN Symposium on the Development and Utilization of Geothermal Resources. San Francisco, California. U.S. Government Printing office, Washington, D.C.

Douglas, J. G.. R. J. Serne, D. W. Shannow and E. M. Woodruff. 1976. Geothermal water and gas--collected methods for sampling analysis. Battelle Corporation, Pacific Northwest Laboratories (BNWL 2094).

Dow Chemical Company (Texas Division). 1977. Removal of hydrogen sulfide from simulated geothermal brines with oxygen. Energy Research and Development Administration (Contract No. 76-C-02-2797).

Druitt, C. E. 1976. Mean annual temperature map--State of Arizona. Arizona Oil and Gas Consumers Committee (Map. GT-2).

Dryden, F. D. 1970. Mineral removal by ion exchange and electrodialysis. University of California at Berkeley at South Lake Tahoe, Workshop on Wastewater and Reuse.

Eastwood, R. L. 1974. Cenozoic volcanism and tectonism of the southern Colorado plateau. Geology of Northern Arizona, Part I--Regional Studies. p. 238-256. In Karlstrom, T. N. U., G. A. Swann and R. L. Eastwood. Sponsored by Northern Arizona University, Museum on Northern Arizona. U. S. Geological Survey, Center of Astrogeology, Flagstaff, Arizona.

ECOVIEW Environmental Consultants. 1976. Environmental impact report on Borax Lake Area, Lake County, California.

ECOVIEW Environmental Consultants. 1977. A draft environmental impact report for Union 0 il Company Unit \#17, Development Area, Lake: County, California.

EIC Corporation. 1976. Control of hydrogen sulfide emissions from geothermal power plants. Annual Status Report. Energy Research and Development Administration (Contract EY-76-C-02-2730).

Einarsson, S. S. 1975. Geothermal space heating and cooling. Second UN Symposium on the Development and Use of Geotherma1 Resources. San Francisco, California. U.S. Government Printing office. Washington, D.C.

Ellickson, P. L., S. Brewer and K. Knight. 1978. Balancing energy and the environment: The case of geothermal development. RAND. Santa Monica, California. 
El1is, A. J. 1970. Quantitative interpretation of chemical characteristics of hydrothermal systems. Geothermics (Special Issue 2). p. 516-528.

Elston, W. E. and S. A. Northrop. 1976. Cenozoic volcanism in southwestern New Mexico. New Mexico Geologic Society (Special Publication No. 5) 151 p.

Emery, A. F. 1966. Stress intensity factors for thermal stresses in thick hollow cylinders. American Society of Mechanical Engineers. Journal of Basic Engineering. p. 45-51.

Energy Research and Development Administration. 1976. A national p1an for energy research, development and demonstration creating energy choices for the future. Energy Research and Development Administration (76 Vol. 2).

Energy Research and Development Administration. 1976. A bibliography-geothermal resources--exploration and exploitation. National Technical Information Service. U.S. Department of Commerce. Springfield, Virginia.

Environmental Impact Planning Corporation. 1977. Long Ridge geothermal leasehold -- draft environmental impact report. County of Lake Planning Department.

Environmental Protection Agency. 1971. Methods for chemical analysis of water and wastes. Environmental Protection Agency Water Quality Office, Analytical Quality Control Laboratory, Cincinnati. 298 p.

Environmental Protection Agency. 1973. Public health and welfare criteria for noise. Office of Noise Abatement and Control (Report 550/9-73-002).

Environmental Protection Agency. 1976. National interim primary drinking water regulations. 40 CFR Part 142, Federal Register 41(3).

Environmental Protection Agency. 1976. Quality criteria for wate $\dot{r}$. Office of Water and Hazardous Materials (Report 440/9-76-023).

Environmental Protection Agency. 1977a. Geothermal position paper: Environmental Protection Agency regulatory options and research development information needs (Report 600/7-77-092).

Environmental Protection Agency. 1977b. Information on levels of environmental noise requisite to protect public health and welfare with an adequate margin of safety. Office of Noise Abatement and Control (Report 550/9-74-004).

Environmental Protection Agency. 1977c. Survey of environmental regulations and assessment of pollution potential and control technology applications for geothermal resources development (Phase II Report, Contract No. 68-03-2371). 
Ermak, D. L. and P. L. Phelps. 1978. An environmental overview of geothermal development: The Geysers--Calistoga KGRA. Vol. 1. Issues and recommendations. Lawrence Livermore Laboratory. University of California, Livermore.

Eskinazi, S. 1962. Principles of fluid mechanics. Allyn and Bacon, Inc., Boston, Massachusetts. p. 355-372.

Faber, H. A. 1972. Improving community water supplies with desalting technology. Journal of American Waterworks Association.

Fairfax, J. P. and H. K. McCluer. 1972. Hydrogen sulfide abatement-Geysers Power Plant Pacific Gas and Electric Company. (Progress report 7485.3-71).

Farah, O. G. and F. Williams. 1976. Methodology for ranking geothermal reservoirs in nonelectric industrial applications. MITRE Corporation, McLean.

Federal Water Pollution Control Administration. 1968. Water quality criteria. Report of the National Technical Advisory Committee to the Secretary of the Interior.

Fernelius, W. A. 1975. Production of fresh water by desalting geothermal brines -- a pilot desalting program at the East Mesa geothermal field, Imperial Valley, California. Proceedings Second UN Symposium on the Development and Use of Geothermal Resources. San Francisco, Ca1ifornia. U.S. Government Printing Office. Washington, D.C.

Findley, Harris, Wilson and Jones. 1975. Mammals of New Mxico, University of New Mexico Press, Albuquerque.

Finney, J. P. 1973. Design and operation of The Geysers power plant. Geothermal Energy. Stanford University Press.

Forrester, J. A. 1962. Map of outcrops of Tertiary and Quaternary igneous rocks in Arizona. Arizona Bureau of Mines, University of Arizona, Tucson.

Fournier, R. 0. and J. J. Rowe. 1966. Estimation of underground temperatures from the silica content of water from hot springs and wet steam wells. American Journal of Science $264(9): 685-697$.

Fournier, R. O. and A. N. Truesde11. 1970. Chemical indicators of subsurface temperature applied to hot waters of Yellowstone Nationa1 Park, Wyoming, U.S.A. Geothermics Specia1 Issue $2: 529-535$.

Fournier, R. 0. and A. N. Truesde11. 1973. An empirical Na-K-Ca geothermometer for natural waters. Geochem. Cosmochim. Acta $37(5): 1255-1275$. 
Fournier, R. O., D. E. White and A. N. Truesde11. 1974. Geochemical indicators of subsurface temperature. I. Basic assumptions. Journal of Research, United States Geological Survey 2(3):259-262.

Fuchs, R. L. and G. W. Hutter. 1975. Geothermal energy: slow moving industry heats up. Engineering and Mining Journal. 178(1):89.

Gennis and Associates. 1977. Draft environmental impact report: McCu1loch Oil Corporation, Cobb Valley Geothermal Leasehold. County of Lake Planning Department.

Geonomics, Inc. 1976. A comparison of hydrothermal reservoirs of the western U.S. Electric Power Research Institute.

Georlitz, D. F. and E. Brown. 1972. Methods for analysis of organic substances in water. U.S. Geological Survey (Techniques of water resources inventory, book 5 , chapter A3).

Georlitz, D. F. and W. L. Lamar. 1967. Determination of phenoxy acid herbicides in water by electron-capture and microcoulometric gas chromotography. U.S. Geological Survey (Water supply paper 1817-C).

Geothemal Advisory Council. 1976. Institutional barriers to geothermal energy development. Government Printing Office, Washington, D.C.

Gerlach, T., D. Norton, K. J. DeCook and J. S. Summer. 1975. Geothermal water resources in Arizona, feasibility study, project completion report. U.S. Department of the Interior, Office of Water Resources (Research Project A-054-Arizona). Washington, D.C.

Gleason, M. N., R. E. Gossolin, H. C. Hodge and R. P. Smith. 1969. Clinical toxicology of commercial products. Williams and Wilkinson Company. Baltimore, Maryland.

Godwin, L. H., L. B. Haigler, R. L. Rioux, D. E. White, L. J. P. Muffler and R. G. Wayland. 1971. Classification of public lands valuable for geothermal steam and associated geothermal resources. U.S. Geological Survey (Circular 647).

Gray, J. R. 1977. Kinds and costs of recreational pollution in the Sandia Mountains. Agricultura1 Experiment Station New Mexico State University, Las Cruces (Bu1letin 651).

Grieder,R. 1973. Economic considerations for geothermal exploration in the western United States. Symposium of Geothermal Energy, Colorado Geological Survey, Denver.

Griffith, A. A. 1924. The theory of rupture. Proceedings of the First International Congress of Applied Mechanics. Delft Publishers.

GRIPS Commission (A California Joint Powers Agency). 1978. GRIPS Plan. 1211 First Street, Napa. 
Gunaji, N., et al. 1978. Geothermal applications feasibility study for the New Mexico State University. New Mexico Energy Institute at New Mexico State University (NMEI 13).

Guthrie, K. M. 1974. Process plant estimating, evaluation and control. Craftsman Book Company.

Guy, H. P. 1969. Laboratory theory and methods for sediment analysis. U.S. Geological Survey (Techniques of water resources inventory, book 5 , chapter $\mathrm{C} 1$ ).

Guy, H. P. and V. W. Norman. 1970. Field methods for measurement of fluvial sediment. U.S. Geological Survey (Techniques of water resources inventory, book 3 , chapter $\mathrm{C} 2$ ).

Haigler, L. B. 1969. Geothermal resources. In mineral and water resources of Arizona. Arizona Bureau of Mines (Bulletin 180). p. 575-577.

Hanna, D., et al. 1979. New Mexico handbook for geothermal resource development, state and local government regulations. New Mexico Energy and Minerals Department.

Hanny, J. A. and B. C. Lunis (eds). 1979. New Mexico hydrothermal commercialization baseline. Department of Energy Resource Applications, Geothermal Resource Office, EG\&G, Inc., Idaho Fa1ls.

Hartley, R. 1978. Pollution control guidance for geothermal energy development. United States Environmental Protection Agency (EPA-600/7-78-101).

Healey, J. H., W. W. Rubey, D. T. Griggs and C. B. Raleigh. 1968. The Denver earthquakes. Science, vol. 161, no. 3848, p. 1301-1310.

Hem, J. D. 1959. Study and interpretation of the chemical characteristics of natural water. U.S. Geological Survey (Water supply paper 1473).

Hesketh, E. H. 1973. Understanding and controlling air pollution. Ann Arbor Science Publishers, Inc. Ann Arbor, Michigan.

Hodson, W. E. 1975. Records of water wells, springs, oil and gas test holes and equivalent rocks of the Powder River Basin. Wyoming State Engineer.

Howard, L. 0. 1895. Animal life in thermal springs. Insect Life. U.S. Department of Agriculture, Division of Entomology. p. 413-414.

Howe, E. D. 1974. Fundamentals of water desalinization. Marcel Dekker Publishers.

Hubbard, J. 1978. Revised checklist of the birds of New Mexico. New Mexico Ornithological Society (Publication \#6). 
Hubbard, J., Conway; Campbe11, Schmitt, and Hatch. 1978. Handbook of species endangered in New Mexico. New Mexico Department of Game and Fish.

Hsu, Y. C. and F. Santosa. 1977. The stability of a large open hydraulic penny-shaped fracture near the earth's surface. (Preliminary Progress Report ME-80(77) LASL-4941). Los Alamos Scientific Laboratories.

Illingworth, R. R. 1976. Factors contributing to annoyance by geothermal steam well venting at The Geysers. Geothermal Environmental Seminar. 1976.

Irwin, G. R. 1958. Handbuck der Physik. Springer, Berlin, Volume $6: 551-590$.

Jaeger, J. C. and N. G. W. Cook. 1969. Fundamentals of rock mechanics. Richard Clay, Bungay, Suffolk, England.

Jhaveri, A. G. 1975. Environmental noise and vibration control at geothermal sites. UN Symposium on Development and Use of Geothermal Resources. San Francisco, California. U.S. Government Printing Office, Washington, D.C.

Jiracek, G. R., C. Smith, M. E. Ander, H. T. Holcombe, M. T. Gerety and C. A. Swanberg. 1977. Geophysical studies at Lightning Dock KGRA, Hidalgo County, New Mexico. Geothermal State of the Art, Geothermal Resources Council. Davis, California. In Press.

Kaufman, E. L. and C. L. B. Siciliano. 1979. Environmental analysis of the Fenton Hill hot dry rock geothermal test site. Los Alamos Scientific Laboratories (LA-7830-HDR).

Kehle, R. 0. 1972. American Association of Petroleum Geologists * geotherma1 survey of North America. United Nations symposium on the Development and Utilization of Geothermal Resources. Geothermics, Special Issue $2(1): 358-367$.

Keith, S. B. 1969. Gypsum and anhydrate. In Mineral and water resources in Arizona. Arizona Bureau of Mines (Bulletin 180). p. $371-382$.

Kennedy, J. 1979. Personal communication to NMEI/NMSU. State Land Office.

Koster. 1957. Guide to the fishes of New Mexico. University of New Mexico Press, Albuquerque, New Mexico.

Kubota, A. and E. Berg. 1968. Evidence for magma in the Katmai Volcanic Range. Bulletin of Volcanism 31:175-214.

Lachenbruch, A. H. 1961. Depth and spacing of tension cracks. Journal of Geophysical Research 66(12):4273-4272. 
LaFrance, L. 1979. Feasibility study of geothermal energy for heating greenhouses. New Mexico Energy Institute at New Mexico State University (NMEI 41).

Lamar, W. L., D. F. Georlitz and L. N. Law. 1965. Identification and measurement of chlorinated organic pesticides in water by electioncapture gas chromatography. U.S. Geological Survey (Water supply paper 1817-B).

Laszlo, J. 1976. Application of the Stretford Process for $\mathrm{H}_{2} \mathrm{~S}$ abatement at the Geysers Geothermal Power Plant. Proceedings of the 11th InterSociety Energy Conversion Engineering Conference.

Leitner, P. 1978. An environmental overview of geothermal development: The Geysers--Calistoga KGRA. Volume 3. Noise. Lawrence Livermore Laboratories, University of California, Livermore.

Ligon. 1961. New Mexico birds and water. University of New Mexico Press, Albuquerque.

Ligon. 1961. New Mexico birds and where to find them. University of New Mexico Press, Albuquerque.

Ligner, J. J., N. D. White, L. R. Kisfer and M. E. Moss. 1969. Water resources. In Mineral and water resources of Arizona. Arizona Bureau of Mines (Bulletin 180). p. 471-569.

Liptek, B. G. (ed). 1974. Environmental engineering handbook. Volume III, land pollution. Chilton Book Company.

Lowe11, J. D. 1974. Regional characteristics of porphyry copper deposits of the southwest. Economic Geology 69(5):601-617.

Mahon, W. A. J. 1973. Chemistry of the exploration and exploitation of hydrothermal systems. Geothermics. Special Issue 2:1310-1322.

Marlin, J., et al. 1978. Regional operations research for development of geothermal resources in the southwestern United States. New Mexico Energy Institute at New Mexico State University (NMEI 10).

Matsua, K. 1973. Drilling for geothermal steam and hot water. Geothermal Energy Review of Research and Development. H. C. H. Armstead (ed). UNESCO, Paris, France.

Matumoto, T. 1971. Seismic body waves observed in the vicinity of Mt. Katmai. Alaska and evidence for the existence of molten chambers. Geological Society of America Bulletin 82:2905-2920.

McClintock, F. A. and J. B. Wash. 1962. Friction of Griffith cracks under pressure. Proceedings of the Fourth U.S. Congress of Applied Mechanics. Berkeley, California. 
McDevitt, P. and C.Rao. 1978. The district space heating potential of low temperature hydrothermal geothermal resources in the southwestern United States. New Mexico Energy Institute at New Mexico State University (NMEI 10-1).

McDevitt, P. and K. Nowotny. 1979. The electricity supply potential of geothermal energy in the Rocky Mountain basin and range region, 1980-1990. New Mexico Energy Institute at New Mexico State University (NMEI 30-1).

McDonald, C. L. and C. H. Bloomster. 1977. The geocity model: description and application Battelle Corporation, Pacific Northwest Laboratories, Rich1and (BNWL-SA-6343).

McDonald, C. L., C. H. Bloomster and S. C. Schulte. 1977. GEOCITY: A computer code for calculating costs of district heating using geothermal resources Battelle Corporation, Pacific Northwest Laboratories, Richland (RNWL-2208).

McFarland, R. D. and H. D. Murphy. 1977. Extraction of energy from hydraulically-fractured geothermal reservoirs. 1976 InterSociety Energy Conservation Engineering Conference.

Microgeophysics Inc. 1970. Unpublished maps of historical seismicity for New Mexico and Arjzona.

Miller, A. and V. LeFebre. 1978. Geothermal applications feasibility study for the New Mexico Institute of Mining and Technology Campus. New Mexico Energy Institute at New Mexico State University (NMEI 19).

Moog, J. L. 1976. Can Mg in groundwater prevent heart attacks? Johnson Drillers Journal 1976:7.

Moore, R., E. Wolfe and G. Ulrich. 1976. The San Francisco Mountain geothermal area. Arizona Geothermal Energy Conference 1976. Phoenix, Arizona.

Morgan, P., M. Rejter, W. Seager and C. Swanberg. 1979. Heat flow, contour map. Preliminary report to the New Mexico Energy Institute at New Mexico State University.

Muffler, L. J. P. 1975. Summary of Section I: Present states of resources development. Second UN Symposium on the Development and Use of Geothermal Resources. San Francisco, California. U.S. Government Printing Office, Washington, D.C.

Mundorff, J. C. 1970. Major thermal springs of Utah. Utah Geologic and Mineral Survey (Water Research Bulletin 13).

Murphy, H. D., R. G. Lawton, J. W. Tester, R. M. Potter, D. W. Brown and R. L. Aamodt. 1976. Preliminary assessment of a geothermal energy reservoir by hydraulic facturing. Society of Petroleum Engineers SPE: 6093 . 
National Academy of Sciences, 1973. Water Quality Citeria 1972. Committee on Water Quality Criteria. Washington, D.C.

National Industrial Pollution Control Counc1. 1971. Waste disposal in deep we11s (Subcouncil Report, COM-71-50242).

Nemat-Nassar, S., Z. P. Bazant and H. Ohtsubo. 1976. Hydraulica fracture and heat extraction from hot dry rock masses: a finite element approach. Numerical methods in Geomechanics. Second International Conference on Numerical Methods in Geomechanics. C. S. Desai (ed). American Society for Civil Engineering. Vol. $1: 7981$.

Nemat-Nasser, S., L. M. Keer and K. S. Parihar. 1977. Unstable growth of thermally induced interacting cracks in brittle solids. Geothermal Energy Research Report, Northwestern University.

Nowotny, K. and C. Rao. 1978. Geothermal development and production of electricity in the southwestern United States. New Mexico Energy Institute at New Mexico State University (NMEI 10-2).

O'Conne11, M. F. and R. F. Kaufman. 1976. Radioactivity associated with geothermal waters in the western United States. U.S. Environmental Protection Agency (ORP/LV-75-8A).

O'Dea, P., et al. 1979. Hydrothermal sites in the Rocky" Mountain basin and range region of the United States. New Mexico Energy Institute at New Mexico State University.

O'Dea, P., et al. 1979. Geothermal energy: cities and towns in the Rocky Mountain basin and range region, data report. New Mexico Energy Institute at New Mexico State University (NMEI 10-5).

Oil Conservation Division. 1979. Rules and regulations for geothermal resources. Oil Conservation Division, New Mexico Energy and Minerals Department.

Ostroot, G. W. and J. Ramos. 1972. Deep well acid disposal--planning and completion. American Association of Petroleum Geologists.'

Ozawa, T. and Y. Fuji. 1970. Phenomenon of scaling in production wells and the geothermal power plant in the Matsukawa Area. UN Symposium on the Development and Utilization of Geothermal Resources. Pisa, Italy. 2(2).

Pacific Gas and Electric Company. 1975. Amended environmental data statement. (Geysers Unit 13).

Pacific Gas and Electric Company. 1977. Environmental data statement. (Geysers Unit 16).

Peale, A. C. 1886. Lists and analyses of the mineral springs of the United States, a preliminary study. U.S. Geological Survey (Bulletin 32). 
Perry, R. H., C. H.y. Chilton and S. D. Kirkpatrick (eds). 1973. Chemical engineers handbook. McGraw-Hill Publishers. New York.

Phelps, P. L. and L. R. Anspaugh (ed). 1976. Imperial Valley environmental project: progress report. Lawrence Livermore Laboratory, University of California, Livermore (RPT. UCRL-50044-76-1).

Phelps, P. L., D. L. Ermak, L. R. Anspaugh, C. D. Jackson and L. A. Miller. 1978. Preliminary environmental assessments of known geothermal resource areas in the United States. Geothermal Resources Council Transactions. Hilo, Hawaii. Vol. 2:523.

Porterfield, G. 1972. Computation of fluvial sediment discharges. U.S. Geological Survey (Techniques of water resources inventory, book 3, chapter C 3 ).

Presser, T. S. and I. Barnes. 1974. Special techniques for determining chemical properties of geothermal water. U.S. Geologica1 Survey (Water Resources Investigations 22-74).

Raleigh, C. B., J. H. Healey and J. O. Bredehoeft. 1976. An experiment in earthquake control at Rangely, Colorado. Science, vol. 191, p. 1230-1236.

Ramachandran, G. 1977. Economic analyses of geothermal energy development in California. Stanford Research Institute, Menlo Park (SAN-115P108-1 Vo1. 1).

Rascheri, R. and W. S. Cook. 1976. Exploration and development of geothermal resources. U.S. Geological Survey. Office of the Area Geothermal Supervisor.

Reid, H. F. 1911. Remarkable earthquakes in central New Mexico in 1906 and 1907. Bulletin of the Seismological Society of America $1: 10-16$.

Reistad, G. M. 1975. Analysis of potential nonelectric applications of geothermal energy and their place in national economics. Lawrence Livermore Laboratories, University of California, Livermore (UCRL-51747).

Reiter, M., C. L. Hartman and C. Weidman. 1975. Terrestrial heat flow along the Rio Grande Rift, New Mexico and southern Colorado. Geological Society of America Bulletin. Vol. 86:811-818.

Reiter, M. 1979. Deep terrestrial heat flow measurements in New Mexico and neighboring geologic area. New Mexico Energy Institute at New Mexico State University (NMEI 38).

Renner, J. L., D. E. White and D. L. Williams. 1975. Hydrothermal convection systems. In Assessment of geothermal resources in the United States. U.S. Geological Survey (Circular 726). 
Rosenblad, A. E. 1976. Evaporator systems for black liquor concentration. Chemical Engineering Progress 72:53.

Roy, R. F., D. D. Blackwell and E. R. Decker. 1972. Continental heat flow. In E. C. Robertson (ed). Nature of the solid earth. McGraw-Hi11 Publi.shers, New York. p. 506-543.

Rubey, W. W. and K. J. Marata. 1941. Chemical evidence bearing on origin of a group of hot springs. Washington Academy of Sciences Journa $131(4): 169-170$.

Sadow, R. 1972. Pretreatment of industrial wastewater for subsurface injection. American Association of Petroleum Geologists.

Sanford, A. 1979a. Seismic exploration for shallow magma bodies in the vicinity of Socorro, New Mexico: phase one. New Mexico Energy Institute at New Mexico State University (NMEI 28).

Sanford, A. 1979b. Seismic activity in New Mexico. Preliminary report to the New Mexico Energy Institute at New Mexico State University.

Sanford, A. R., 0. Alptekin and T. R. Toppozada. 1973. Use of reflection phases on microearthquake seismograms to map an unusual discontinuity beneath the Rio Grande rift. Bulletin of, the Seismological Society of America 63:2021-2034.

Sanford, A. R. and D. J. Cash. 1969. An instrumental study of New Mexico earthquakes. New Mexico Bureau of Mines and Mineral Resources (Circular 102).

Sanford, A. R. and L. T. Long. 1965. Microearthquake crustal reflections, Socorro, New Mexico. Bulletin of the Seismological Society of America 55:519-586.

Sanford, A. R. and C. R. Holmes. 1962. Microearthquakes near Socorro, New Mexico. Journal of Geophysical Research 67:4449-4459.

Sanford, A. and Schlue, J. 1979. Seismic exploration for shallow knagma bodies in the vicinity of Socorro, New Mexico. New Mexico Energy Institute at New Mexico State University (NMEI 33).

Sanyal, S. K. 1977. Preliminary compliation of chemical composition of geothermal waters. Geonomics, Inc.

Sass, J. H., W. H. Diment, A. H. Lachenbruch, B. V. Marshall, R. J. Munroe, T. H. Moses, Jr., and T. C. Urban. 1976. A new heat flow contour map of the conterminous United States. U.S. Geological Survey (Open File Report 76-756).

Sass, J. H., A. H. Lachenbruch, R. J. Munroe, G. W. Creene and T. H. Moses. 1971. Heat flow in the western United States. Journal of Geophysical Research 76(26):6376-6413.

Sauck, W. A. and J. S. Sumner. 1970. Residual aeromagnetic map of Arizona. Department of Geosciences, University of Arizona, Tucson. 
Sax, N. I. 1968. Dangerous properties of industrial materials. Rheinhold Book Corporation.

Schock, R. and A. Duba. 1975. Effects of electrical potential on scale formation in Salton Sea Brine. Lawrence Livermore Laboratories, University of California, Livermore (Contract W-740S-Eng-48).

Schuller, C. R., A. H. Schilling, R. J. Cole and G. D. Simon. 1976. Legal, institutional and political problems in producing power from geothermal resources in California. Battelle Research Report. Battelle Corporation, Richland.

Schultz, A. R. 1918. A geologic reconnaissance for phosphate and coal in southeastern Idaho and western Wyoming. U.S. Geological Survey (Bulletin 680).

Scott, J. D. and R. T. Moore. 1976. The Palo Verde Nuclear Power Station--Geotechnical considerations in site selection. Field Notes from the Arizona Bureau of Mines. 6(3-4):1-7.

Simmons, G. M. 1977. Economics and projections for geothermal development in the northwest. Geothermal Energy Magazine 5(10):

Smith, J. H. 1973. Collection and transmission of geothermal fluids in geothermal energy review of research and development. H. C. H. Armstead (ed). UNESCO, Paris, France.

Smith, M. C. 1973. The potential for the production of power from geothermal resources. Los Alamos Scientific Laboratories, Los Alamos (LA-UR-73-926).

Smith, M. C. 1974. Geothermal power: problems and progress. Los Alamos Scientific Laboratories, Los Alamos (LA-UR-74-566).

Sociotechnical Systems, Inc. 1977. Draft environmental impact report, northern California power agency/resource funding limited, Cobb Valley geothermal project. County of Lake Planning Department.

Soil 1 Conservation Service. 1978. Potential natural vegetation, New Mexico. Soil Conservation Service (New Mexico Interagency Range Committee Report No. 11).

Solar America, Inc. 1978. Utilization of natural flowing low temperature geothermal spring waters for year-round crop production in a commercial solar-assisted greenhouse. A proposal to the New Mexico Energy and Minerals Department.

Southwestern New Mexico Services to Handicapped Children and Adults, Inc. 1978. Demonstration of a geothermally heated greenhouse for the production of native plants by the handicapped. A Proposal to the New Mexico Energy and Minerals Department, Santa Fe.

Spiegler, K. S. 1966. Principles of desalination. Academic Press, New York. 
Stanford Research Institute. 1977. Environmental analysis for geothermal energy development in The Geysers region. Report for the California Energy Resources Conservation and Development Conservation (Volume I. Summary).

Starkey, A. Personal communication. New Mexico Energy Institute at New Mexico State University.

Starkey, A. and Thompson, C. 1979. Prospect for geothermal energy development in New Mexico. New Mexico Energy Institute at New Mexico State University (NMEI 0-4).

State of New Mexico. 1976. New Mexico water resources assessment for planning purposes.

State of New Mexico. 1977. Ambient air quality summaries, 1973-1976. Air Quality Division. Environmental Improvement Agency.

State Planning Division. 1978. Critical areas study. New Mexico Department of Finance and Administration.

Stone, W. and N. Mize1l. 1977. Geothermal resources of New Mexico: a survey of work to date. New Mexico Energy Institute at New Mexico State University (NMEI 5).

Stuart, W. D. and M. J. S. Johnston. 1975. Intrusive origin of the Matsushiro earthquake swarm. Geology 1975:63-67.

Sumners, W. K. 1965. Chemical characteristics of New Mexico's thermal water--a critique. New Mexico Bureau of Mines and Mineral Resources (Circular 83).

Sumners, W. K. 1965. A preliminary report on New Mexico's geothermal energy resources. New Mexico Bureau of Mines and Mineral Resources (Circular 80).

Sumners, W. K. 1971. Annotated and indexed bibliography of geothermal phenomena. Case Thompson Printing Company, Albuquerque, New: Mexico.

Sumners, W. K. 1976. Catalogue of thermal waters in New Mexico. New Mexico Bureau of Mines and Mineral Resources (Hydrologic Report 4).

Sung, R., G. Houser, G. Richards, J. Cotter, P. Walker and E. Pulaski. 1978. Preliminary cost estimates of pollution control technologies for geothermal development Environment Protection Agency (EPA Contract No. 68-03-2650, Work Directive T-S004).

Swanberg, C. A. 1974. The application of the Na-K-Ca geothermometer to thermal areas of Utah and the Imperial Valley, California. Geothermics 13 (2):53-59. 
Swanberg, C. A. 1975: Detection of geothermal components in groundwaters of Dona Ana County, Southern Rio Grande Rift, New Mexico. New Mexico Geologic Society Gujdebook. 26th Field Conference, Las Cruces. p. 175-180.

Swanberg, C. A. 1976. Geothermal investigations in southwest New Mexico. New Mexico Energy Institute at New Mexico State University (NMEI 3).

Swanberg, C. A. and P. Morgan. 1977. The correlation among the silica content of groundwaters, regional heat flow and the geothermal potential of western United States. Abs. of paper presented at IASPEI/AUCEI Assembly, Durham, England.

Swanberg, C. and P. Morgan. 1977. An appraisal study of the geothermal resources of Arizona and adjacent area in New Mexico and Utah, and their value for desalination and other uses. New Mexico Energy Institute at New Mexico State University (NMEI 6-1).

Swanberg, C. 1979a. Subsurface temperatures estimated by silica and sodium-potassium-calcium geothermometers and total dissolved solids in existing wells of New Mexico. Preliminary report to the New Mexico Energy Institute at New Mexico State University.

Swanberg, C. 1979b. Geothermal data from New Mexico geothermal waters. New Mexico Energy Institute at New Mexico State University (Open file report).

Theis, C. V., C. G. Taylor, Jr. and C. R. Murray. 1941. Thermal waters of the hot springs artesian basin, Sierra County, New Mexico. New Mexico State Engineer (14th and 15th Biennial Report).

Thompson, C. Alternate Energy'79 - a research and development report. New Mexico Energy Institute at New Mexico State University (NMEI $0-2)$.

Thompson, C. and Starkey, A. 1979. The geothermal option - a choice for New Mexico. New Mexico Energy Institute at New Mexico State University (NMEI 0-3).

Timmons, A. S. and 0. D. Whitescarver. 1978. Geysers simplified noise model, Unit 17, Geothermal Development Area. Union Oil Company of California, Santa Rosa.

Tolivia, M. 1970. Corrosion measurements in a geothermal environment. UN Symposium on the Development and Utilization of Geothermal Resources. Pisa, Italy. 2(2).

Tolmasof, T. 1976. Report on $\mathrm{N}_{2} \mathrm{~S}$ air quality and The Geysers geothermal development. Northern Sonoma County Air Pollution Control District.

Trehan, R. K., J. G. Leigh and S. Pond. 1976. Economic analysis and benefit assessment of the federal geothermal energy program MITRE Corporation, McLean (MTR-7326). 
Truesde11, A. H. and R. O. Fournier. 1979. Procedure for estimating the temperature of a hot water component in a mixed water using a plot of dissolved silica vs. enthalpy. Journal of Research. U.S. Geologic Survey. In Press.

United Nations. 1970. Proceedings of the United Nations Symposium on the Development and Utilization of Geothermal Resources. Pisa, Italy. Geothermics Special Issue 2, 2(1-2).

United Nations. 1975. Proceedings of the Second United National Symposium on the Development and Use of Geothermal Resources. San Francisco, California. U.S. Government Printing Office, Washington, D.C.

United States Army Corps of Engineers. 1972. Cost curves for conveyance, treatment and storage of wastewater. San Francisco, California.

United States Bureau of Reclamation. 1972. Geothermal resources investigations, Imperial Valley, California, January 1972, development concepts. Bureau of Reclamation, Boulder City, Nevada.

United States Department of Energy (Assistant Secretary for the Environment). 1978. Environmental readiness document (ERD) for hydrothermal electric and direct heat, commercialization, phase III planning (Draft Report).

United States Department of Energy. 1978. Geothermal space heating. EG\&G, Idaho Falls.

United States Department of Energy. 1978. Idaho geothermal project. EG\&G, Idaho Falls.

United States Department of Energy. 1978. Rules of thumb for * geothermal direct applications, resource rules, industrial uses, space heating, economics, conversion factors. EG\&G, Idaho Falls.

United States Department of Energy. 1978. Environmental development plan (EDP). Department of Energy (Report DOE/EDP-0014).

United States Department of the Interior. 1976. Geothermal resources operational orders. U.S. Geological Survey, Office of the Area Geothermal Supervisor.

United States Department of the Interior. 1977. Guidelines for acquiring environmental baseline data on federal geothermal leases. U.S. Geological Survey.

United States Envi ronmental Protection Agency. 1971. Noise from construction equipment and operations, building equipment and home appliances. Bolt, Beranek and Newman.

United States Environmental Protection Agency. 1971. Transportation noise and noise from equipment powered by internal combustion engines (Report NTID 300.13). 
Unjted States Environmental Protection Agency. 1974. Information on the levels of environmental noise requisite to protect public health and welfare with an adequate margin of safety. (Document 550/9-74-004).

United States Environmental Protection Agency. 1977. Waste stabilization ponds. Black and Veach Consulting Engineers.

United States Environmental Protection Agency. 1978. Pollution control guidance for geothermal energy development. Cincinnati, Ohio.

United States Geological Survey. 1971. Chemical quality of water in southeastern Wyoming. Wyoming District U.S. Geological Survey Water Resources Division.

United States Geological Survey. 1974. 1972 water resources data for New Mexico, Part 1 - surface water records. United States Department of the Interior.

United States Geological Survey. 1976. Conservation of lands and minerals. U.S. Geological Survey Annual Report (Fiscal Year 1976).

United States Geological Survey. 1978. Geothermal sites in the United States. United States Geological Survey (Circular 790).

United States Public Health Service. 1962. Public health service drinking water standards. Public Health Service Publication 956. U.S. Government Printing Office, Washington, D.C.

United States Public Health Service. 1969. Preliminary air pollution survey of hydrogen sulfide. A literature review. Consumer Protection and Environmental Health Service.

VanWindle, W. and H. Mignotte. 1964. A guide to the selection of * cost-effective wastewater treatment systems. Environmental Protection Agency (Report 430/9-75-002).

Waring, G. A. 1965. Thermal springs of the United States and other countries of the world--A summary. U.S. Geological Survey (Professional Paper 492).

Warner, D. 1965. Deep-well disposal of industrial wastes. Chemical Engineering $72: 73-78$.

Welder, G. E. 1968. Groundwater reconnaissance of the Green River Basin, southwestern Wyoming. U.S. Geological Survey (Hydrologic Atlas -- 290).

West, R. E. and J. S. Sumner. 1973. Bouguer gravity anomaly map of Arizona. Laboratory of Geophysics, Department of Geoscience, University of Arizona, Tucson.

West, V. 1977. Noise element of the general plan, Lake County, Californi.a. Sociotechnical Systems, Inc. 
Whitcomb, H. A. and M. E. Lowry. 1968. Groundwater resources and geology of the Wind River Basin area, central Wyoming. U.S. Geological Survey (Hydrologi Atals HA-270).

White, D. E. 1965. Geothermal Energy. U.S. Geologica1 Survey (Circular 519).

White, D. E. 1970. Geochemistry applied to the discovery, evaluation and exploitation of geothermal energy resources. Geothermics Special Issue 2:58-80.

White, D. E. 1973. Characteristics of geothermal resources in geothermal energy. Kurger and Otte (eds). Stanford University Press.

White, D. E. and D. L. Williams (eds). 1975. Assessment of geothermal resources of the United States. U.S. Geological Survey (Circular 726).

Wilson, E. D., R. T. Moore and J. R. Cooper. 1969. Geologic map of Arizona. Arizona Bureau of Mines, Tucson.

Wood, B. 1973. Geothermal power. In H. C. Armstead (ed). Geothermal energy review of research and development. UNESCO, Paris, France.

Woodruff, E. G. 1909. Sulphur deposits near Thermopolis, Wyoming. U.S. Geological Survey (Bulletin 380-M).

Woolard, C. P. and H. R. Joesting. 1964. Bouguer gravity anomaly map of the United States. American Geophysical Union Special Committee for the Geophysical and Geological Study of the Continents, Washington, D.C.

Yanagase, T., Y. Suginohara and K. Yanagase. 1970. Properties of " scales and methods to prevent them. UN Symposium on the Development and Utilization of Geothermal Resources. Pisa, Italy. $2(2)$. 
APPENDIX A

STEERING COMMITTEE MEMBERS

INDUSTRY

Lyle Berger, Ecologist

Union Oil Company of New Mexico

4100 Southern B1vd SE

Rio Rancho, New Mexico 87174

FEDERAL AGENCIES

Robert L. Quade

Recreation and Land Office

U.S. Forest Service

P.O.Box 1689

Santa Fe, New Mexico 87501

\section{CITIZENS GROUPS}

John R. Bart1it

New Mexico Citizens for Clean

Air and Water

113 Monte Rey Drive North

White Rock, New Mexico 87544

\section{STATE AGENCIES}

Cubia Clayton

Environmental Improvement Division Health and Environment Department P.O. Box 968

Santa Fe, New Mexico 87503

George Scudella

Natural Resource and Development Division

Energy and Minerals Department

P.0. Box 2770

Santa Fe, New Mexico 87503

\section{INSTITUTES AND RESEARCH LABORATORIES}

Joseph Marlin

New Mexico Energy Institute at NMSU

Box 3EI

New Mexico State University

Las Cruces, New Mexico 88003
David Sabo, Environmental Affairs Public Service Company of New Mexico P.0.Box 2267

Albuquerque, New Mexico

87103

\author{
James Querry \\ Geothermal Specialist \\ Bureau of Land Management \\ P.0. Box 1449 \\ Santa Fe, New Mexico 87501
}

Pauline Eisenstadt

Energy Consumers of New Mexico, Inc.

117 Richmond NE

Albuquerque, New Mexico 87106

Bill Isaacs

New Mexico Heritage Program

Natural Resources Department

Villagra Building

Santa Fe, New Mexico 87503 :
Ken Rea

Los Alamos Scientific Laboratory

P.O. Box 1663, Group H12

Mail Stop 490

Los Alamos, New Mexico 87545 
Project Manager:

Dr. William A. Dick-Peddie

New Mexico Environmenta1

Institute

New Mexico State University

Las Cruces, New Mexico 88003
Project Director:

Arlene H. Starkey

New Mexico Energy Institute at NMSU

Box 3EI

New Mexico State University

Las Cruces, New Mexico 88003 
APPENDIX B

LIST OF PEOPLE INVITED TO WORKSHOP. ATTENDEES ARE INDICATED BY AN ASTERISK (*).

Ear1 F. Aldon

Rocky Mountain Experiment Station

U.S. Forest Service

517 Go1d SW

Albuquerque, New Mexico 87101

Kay Anderson

6200 Indian School Road NE

Box 303

Albuquerque, New Mexico 87110

Phelps Anderson

City of Roswell

Box 1000

Roswe11, New Mexico 88201

D. B. Anthony

7112 Bellrose Avenue

Albuquerque, New Mexico 87110

Bery 1 Asplund

100 Circle Drive

Santa Fe, New Mexico 87501

Thomas E. Baca

Environmental Improvement Division

P.O. Box 968

Santa Fe, New Mexico 87503

Thomas G. Bahr

Water Resources Research Institute

Box 3167

New Mexico State University

Las Cruces, New Mexico 88003

* Pete Balleau

Bureau of Indian Affairs

Albuquerque Area office

Box 8377

Albuquerque, New Mexico

87198

Ken Balizer

Southwest Research and Information Center

Lomas Avenue

Albuquerque, New Mexico 87106 
* John Bartit

New Mexico Citizens for Clean Air and Water

113 Monte Ray Drive N

Los Alamos, New Mexico 87544

J. Bednerik

Institute of American Drilling Contractors

P.0. Box 4287

Houston, Texas 77210

Dick Bemis

$B \& K$ Instruments, Inc.

119 Quincy NE

Albuquerque, New Mexico 87108

W. C. Bennett

Environmental Manager

Environmental Improvement Division

4159 Montgomery NE

Albuquerque, New Mexico

87411

Gary W. Bequette

Police Department

County of Los Alamos

P.o. Box 30

Los Alamos, New Mexico

87545

* Lyle Berger

Union Oi1 of New Mexico

4100 Southern B1vd SE

Rio Rancho, New Mexico 87174

* George J. Biggs

Board Member for Geothermal Energy

Los Alamos Office

New Mexico Citizens for Clean Air and Water P.0. Box 5

Los Alamos, New Mexico 87544

Esther Y. Bottom, R.N.

Los Alamos Scientific Laboratories

Los Alamos, New Mexico 87545

John Bradley

County of Los Alamos

Box 30

Los Alamos, New Mexico 87544

Luther Branham

Department of Housing and Urban Development

Federal Housing Administration

625 Truman NE

Albuquerque, New Mexico 87110 
Lee Briggs

Chairman of Science and Math

Navajo Community College

Shiprock, New Mexico 87420

Bob Brisco

New Mexico Environmental Health Association

4159 Montgomery B1vd. NE

Albuquerque, New Mexico 87109

Michael F. Brown

Environmental Improvement Division

Box 2410

Gallup, New Mexico 87301

Pat Brown

933 Capulin Road

Los Alamos, New Mexico 87544

* Martha Bryant

New Mexico Energy Institute at NMSU

Box 3EI

New Mexico State University

Las Cruces, New Mexico 88003

Tom Burt

Environmental Improvement Division

406 North Guadalupe

Carlsbad, New Mexico 88220

Larry L. Byrd

Box 1149

New Mexico State Highway Department

Santa Fe, New Mexico 87501

Brant Calkin

Southwest Region, Sierra Club

338 E. DeVargas

Santa Fe, New Mexico 87501

Gary Car1son

Natural Resource and Development Division

Energy and Minerals Department

Box 2770

Santa Fe, New Mexico 87503

Larry T. Caudill

Box 4749

Albuquerque, New Mexico 87106

Charles N. Cawley

Department of Design and Environmental Analysis

Cornell University

Ithaca, New York 14850 


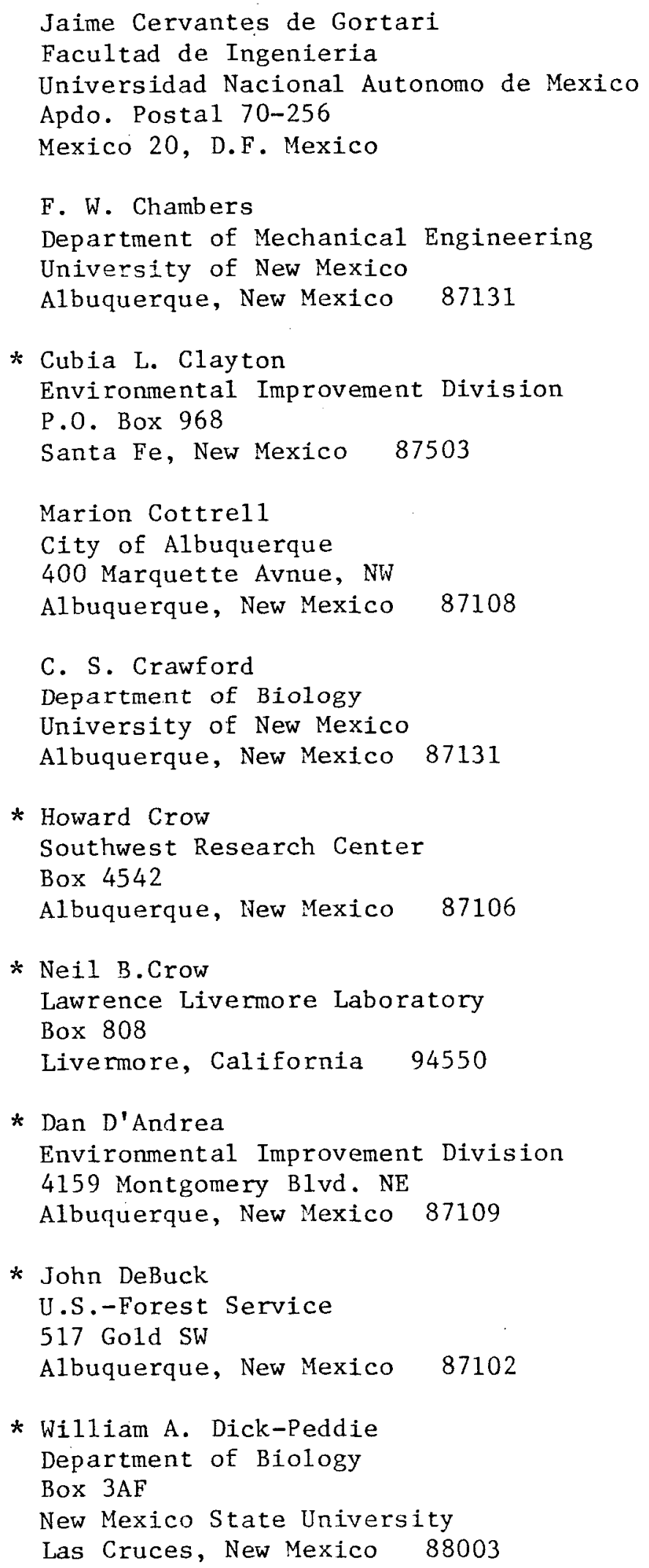




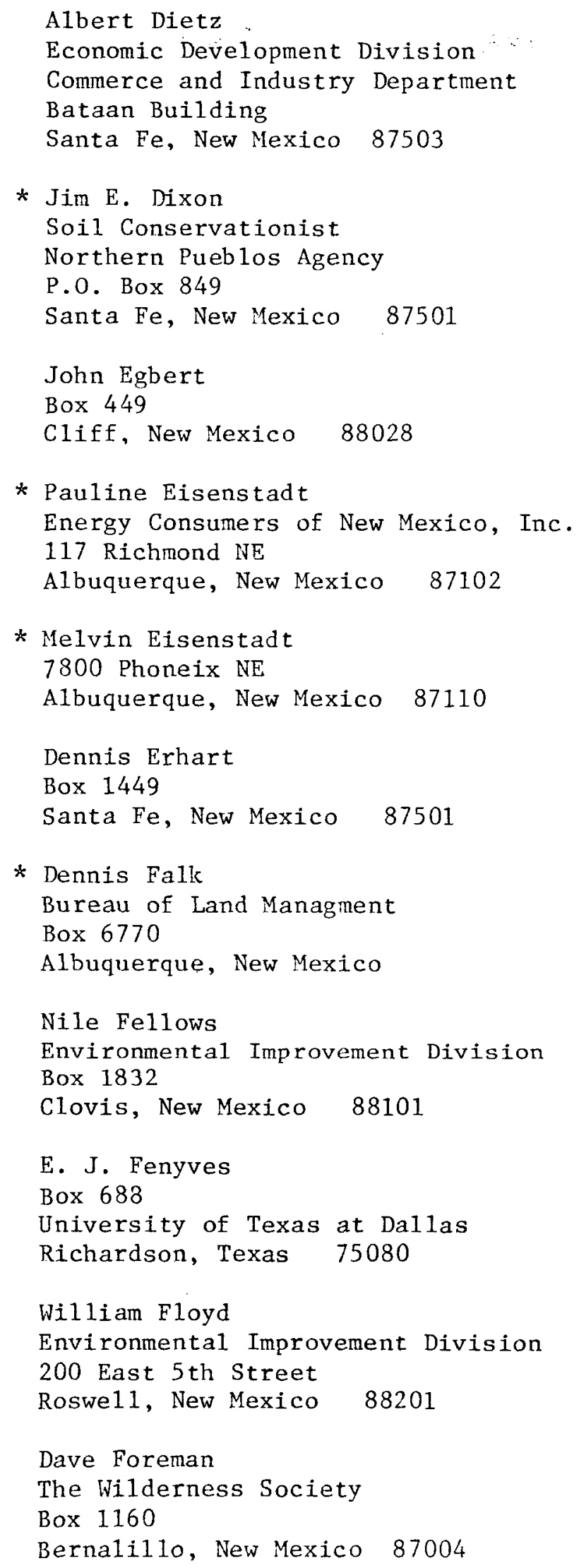


* Richard Forester

U.S. Geological Survey

2465 E. Bayshore

Palo Alto, California

94303

P. Forrest

Box 909

Santa Fe, New Mexico 87501

Phil Freeman

Department of Game and Fish

Capitol Building

Santa Fe, New Mexico 87503

George Goldstein

Health and Environmental Department

P.0. Box 968

Santa Fe, New Mexico 87503

James Gosz

Biology Department

University of New Mexico

Albuquerque, New Mexico 87131

Maggie Gover

Americans for Indian Opportunity

600 2nd Street NW

Plaza del Sol Building, Suite 403

A1buquerque, New Mexico 87102

Porter Grace

Department of Energy

Special Programs Division

Box 5400

Albuquerque, New Mexico 87185

* P. R. (Bob) Grant

Energy Resources Exploration, Inc. 9720-D Candelaria NE

Albuquerque, New Mexico 87112

* D. E. Gray

State Engineers Office

Bataan Memorial Building

State Capitol

Santa Fe, New Mexico 87503

John E. Guinn

Environmental Improvement Division

200 E 5th Street

Roswe11, New Mexico 88201 
Tommy Hampton

City of Las Vegas

P.0. Box 179

Las Vegas, New Mexico 87701

* David Hanna

219 W. Manhattan Avenue

Santa Fe, New Mexico 87501

LaDonna Harris

Americans for Indian Opportunity

600 2nd Street NW

Plaza del Sol Building, Suite 403

Albuquerque, New Mexico 87102

* Les Hawkins

7532 Bear Canyon Road NE

Albuquerque, New Mexico 87109

J . P. Hubbard

2016 Valle Rio

Santa Fe, New Mexico 87501

C. A. Hundertmark

233 Morningside $\mathrm{NE}$

Albuquerque, New Mexico 87108

* John D. Hunter

Bandelier National Monument

Los Alamos, New Mexico 87544

Lawrence B. Ingham

Box 2348

Santa Fe, New Mexico 87503

* Bill Isaacs

New Mexico Heritage Program

Natural Resources Department

Villagra Building

Santa Fe, New Mexico 87503

Calvin Jackson

Director of Health and Environment

Department of Energy

San Francisco Field Office

Oakland, California 94612

Bob Jensen

County of Los Alamos

Box 30

Los Alamos, New Mexico 87544 
* Roni Johnson

American Indian Puelbo Council

1015 Indian School Road NW

Albuquerque, New Mexico

* Nikki Jones

Environmental Improvement Division

Box 968

Crown Building

Santa Fe, New Mexico 87503

Donald Jordan

City of Gallup

P.O. Box 1270

Gallup, New Mexico 87301

* Frank Kingery

Westec Services, Inc.

3211 Fifth Avenue

San Diego, California 92103

* Robert Kirkpatrick

Environmental Improvement Division Box 968

Santa Fe, New Mexico 87503

* Gary Klimowicz

Knowledge Base Systems

425 Dartmouth NE

Albuquerque, New Mexico 87106

Gary Langhorst

Los Alamos Scientific Laboratories

Mail Stop 495

Los Alamos, New Mexico

* George K. Laskar

Bureau of Land Management

12200 Vienna NE

Albuquerque, New Mexico 87111

Jay Lazarus

Environmental Improvement Division

Box 968

Santa. Fe, New Mexico 87503

Vernon LeFebre

New Mexico Tech

Campus Station

Socorro, New Mexico 87801

* Philip Leitner

Biology Department

St. Mary's College

Moraga, California 
James $\mathrm{K}$. Libberton

Noise Control Unit

Environmental Improvement Division

Box 968

Santa Fe, New Mexico 87503

Lincoln County Land and Cattle Company

Box 338

Roswe11, New Mexico 88201

Lee Lockie

Air Quality Section

Environmental Improvement Division

Box 968

Santa Fe, New Mexico 87503

Jose G. Lucero

Police Department

City of Taos

Drawer 11

Taos, New Mexico 87571

Raymond A. Madson

Environmental Improvement Division

708 Uranium

Milan, New Mexico 78021

Alexander B. Maish

Org. 4741

Sandia Laboratories

Albuqeurque, New Mexico 87185

* Thomas Mancini

Department of Mechanical Engineering

Box 3450

New Mexico State University

Las Cruces, New Mexico 88003

* J. M. Marlin

New Mexico Energy Institute at NMSU

Box 3EI

New Mexico State University

Las Cruces, New Mexico 88003

* Art Martinez

Public Service Company of New Mexico

Box 2267

Albuquerque, New Mexico

87103 
* Marilyn A. Marquis

Department of Energy

Geotherma1 Demonstration Power Plant

Project Office

Plaza De1 Sol Building

Room 712, 600 2nd Street NW

Albuquerque, New Mexico 87102

W. W. McClellan

Public Safety Division

Box 5070

Las Cruces, New Mexico 88003

Pat McDermitt

City Manager

City of Las Vegas

Box 179

Las Vegas, New Mexico 87704

Carol Mc Donald

Bureau of Land Management

Box 1449

Santa Fe, New Mexico 87501

* Ruth Meincke

1712 San Cristobal SW

Albuquerque, New Mexico 87104

Mike Mendias

Environmental Protection Agency

1201 E1m Street

Dallas, Texas 75270

J. T. Michelson

Sunbe11 Corporaion

Box 7500

Albuquerque, New Mexico 87104

* Felix Miera

Los Alamos Scientific Laboratories

Mail Stop 495

Los Alamos, New Mexico 87545

* Chuck Molenkamp

Lawrence Livermore Laboratory

Box 808

Livermore, California 94550

* Garland Moore

National Park Service

Box 728

Santa Fe, New Mexico 87501 


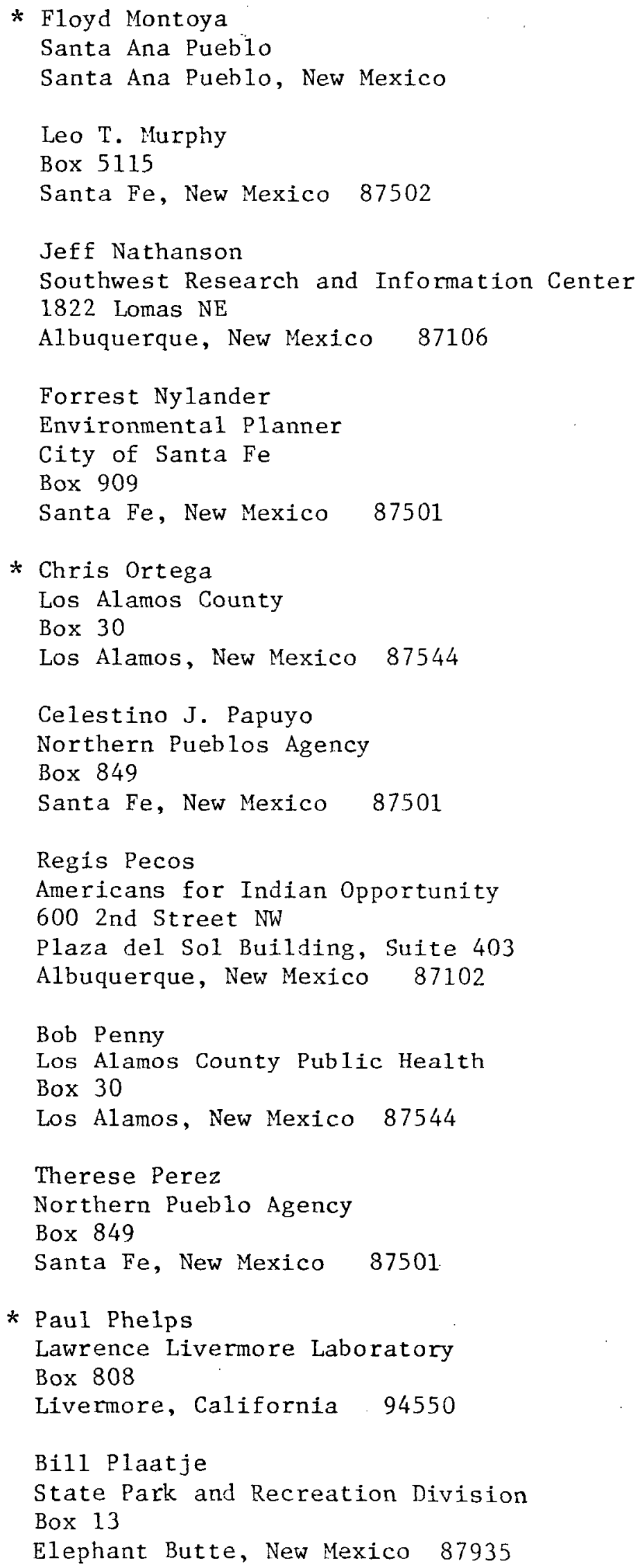




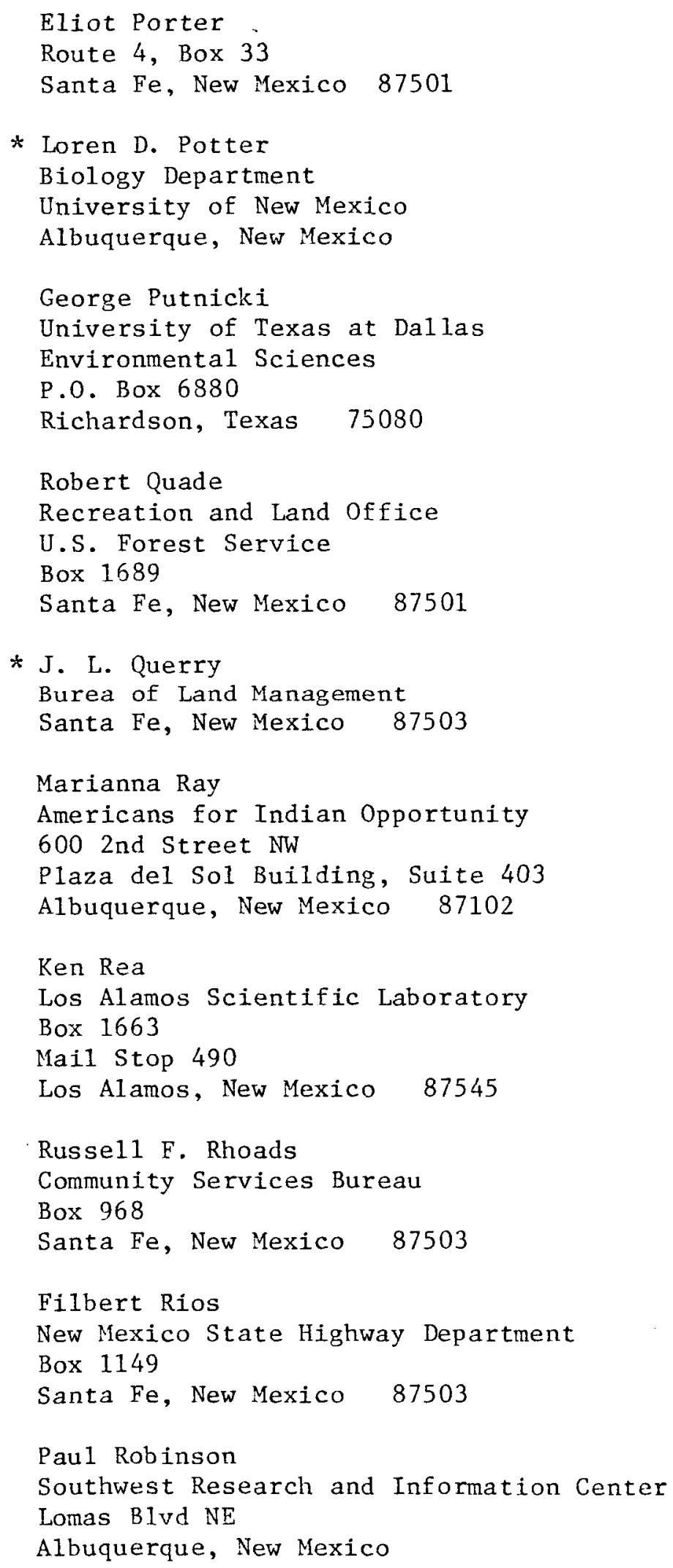


* David Sabo

Public Service Company of New Mexico

P.0. Box 2267

Albuquerque, New Mexico 87103

* Doug Sacarto

National Council of State Legislatures

1405 Curtis Street, 23rd Floor

Denver, Colorado 80202

Nick Salazar

Box 5115

Santa Fe, New Mexico 87502

N. Samadi

Box 688

University of Texas at Dallas

Richardson, Texas 75080

* Harold Sando

Office of Natural Resources

A11 Indian Pueblo Council, Inc.

Box 6507

1015 Indian School Raod NW

Albuquerque, New Mexico

A1 Sanford

Geoscience Department

New Mexico Tech

Campus Station

Socorro, New Mexico 87801

Thomas S. Scanlon, Jr.

New Mexico State Highway Department

Box 1149

Santa Fe, New Mexico 87503

Tracy Schofield

Los Alamos Scientific Laboratories

Mai1 Stop 495

Los Alamos, New Mexico

* Dave Schultz

517 Gold Avenue SW

Albuquerque, New Mexico 87102

Bil1 Schurkens

New Mexico Wildlife Federation

142 Monroe NE

Albuquerque, New Mexico

* George Scudella

Energy and Minerals Department

Box 2770

Santa Fe, New Mexico 87501 


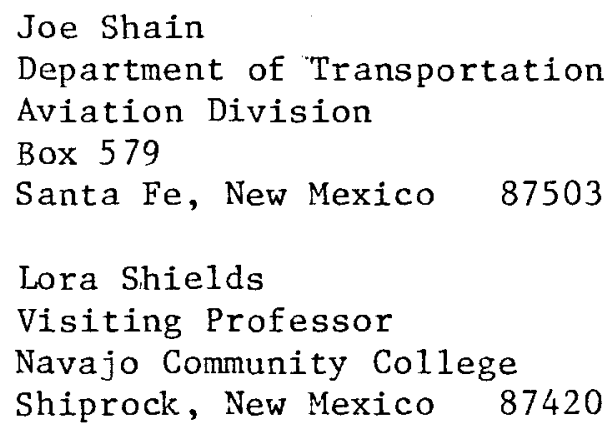

William Sisneros

City of Taos

Drawer $M$

Taos, New Mexico 87571

Warren Slade 4048A Sycamore

Los Alamos, New Mexico 87544

* Edward W. Smith

Eight Northern Indian Pueblos Council

Box 969

San Juan Pueb1o, New Mexico 87566

Mat thew W. F. Smith

UNM Center for Ent. and Comm. Disorders 2211 Lomas B1vd, NE

Albuquerque, New Mexico 87131

Ted Smith

Council of Energy Resource Tribes

Suite 312 , $5670 \mathrm{~S}$. Syracuse Circle

Englewood, Colorado: 80110

Betty Stacey

American Association of Retired Persons Box 1293

Albuquerque, New Mexico 87103

* Arlene H. Starkey

New Mexico Energy Institute at NMSU

Box 3EI

New Mexico State University

Las Cruces, New Mexico 88003

* Martin Suhr

U.S. Fish and Wildlife Service Box 1306

Albuquerque, New Mexico 87103 
* Able Suniga

Bureau of Land Management

200 Neal Street

Socorro, New Mexico 87801

E. A. Swenson

Box 2007

Albuquerque, New Mexico 87003

* Edwin Tafoya

Santa Clara Pueblo

Box 580

Espanola, New Mexico 87532

* Paul Tafoya

Santa Clara Pueb1o

Box 580

Espanola, New Mexico 87532

D. Taylor

New Mexico Conservation Coordinating Council

Box 142

Albuquerque, New Mexico

87103

Denise Tessier

Draw J

Albuquerque, New Mexico 87103

* David Townsend

New Mexico Technology Review

707 Peachtree Road

Rio Rancho, New Mexico 87124

Peter J. Valencia, Director

Motor Transportation Division

Box 1028

Santa Fe, New Mexico 87503

* Anselmo Valverde

Northern Pueblos Agency

Box 849

Santa Fe, New Mexico 87501

* Barry Welch

Bureau of Indian Affairs

Albuquerque Area Office

Box 8327

A1buquerque, New Mexico 87198

* F. G. West

Los Alamos Scientific Laboratories

Mail Stop 983

Box 1663

Los Alamos, New Mexico 87544 
* Eugene M. Wewerka

Los Alamos Scientific Laboratories

Mail Stop 495

Los Alamos, New Mexico 87454

Bob White

Aviation Division

New Mexico Department of Transportation

Santa Fe, New Mexico 87503

* J. Williams

Bureau of Land Management

200 Neal Street

Socorro, New Mexico 87801

Lee Wilson

Lee Wilson and Associates

Box 931

Santa Fe, New Mexico 87501

John S. Winder

Environmental Protection Agency

401 M. Street SW

Washington, D.C. 20460

Nelson Wurgler

1880 Golden Drive

Las Cruces, New Mexico 88001

* Keith A. Yarborough

Division of Natural Resources

Southwest Regional office

National Park Service

Box 728

Santa Fe, New Mexico 87501

Ron Zee

Department of Energy

Box 1702

Santa Fe, New Mexico 87501

Samuel Zeigler

Department of Occupational Medicine

Box 1163

Los Alamos, New Mexico 87545

Henry Zeller

Box 870

Silver City, New Mexico 88061 


\section{APPENDIX C}

WORKSHOP FOR

AN ENVIROMMENTAL OVERVIEW FOR THE DEVELOPMENT OF GEOTHERMAL RESOURCES

IN THE STATE OF NEW MEXICO

Friday and Saturday, September 7-8, 1979

Albuquerque Convention Center

$$
8 \text { a.m. }-5 \text { p.m. }
$$

Sponsored by:

The New Mexico Energy Institute at New Mexico State University and

The New Mexico Environmental Institute

Friday, September 7, 1979

7:45 REG ISTRATION

8:15 GENERAL SESSION

Welcome to Workshop -- NMEI/NMSU

DOE

Goals of the Workshop and Environmental Overview Project

DOE/LLL

NMEI/NMSU

Using Geothermal Energy -- a brief description of geothermal systems and extraction technologies: NMEI/NMSU

Hot Dry Rock System

Hydrothernal Systems

Vapor-dominated

Water-dominated

Volcanic

Rift Valley

Geopressured

Geothermal Energy Resources in New Mexico

Overview of Geothermal. Sites -- Hot dry rock and hydrothermal, high and low temperature sites

Geothermal Extraction Technologies -- Existing or in the process of development

Potential Geothermal Technologies that can be used in New Mexico 
10:00 BREAK

10:15 GENERAL SESSION -- PANEL PRESENTATION

Potential environmental impacts resulting from location of geothermal sites in New Mexico

Potential environmental impacts resulting from extraction technology in New Mexico

Electrical generation

Separated steam process

Single-flash process Separated-steam/Single-flash process

Binary cycle process

Hot dry rock process

Direct heat applications

Direct use of water

Surface heat exchanger

Down-the-hole heat exchanger

Heat pump

QUESTIONS AND ANSWERS ON GEOTHERMAL TECHNOLOGY/SITE LOCATION AND

ENVIRONMENTAL IMPACTS

12:00 LUNCH (at Convention Center)

1:30 SMALL GROUP DISCUSSIONS (On Section 4 of Draft Document)

Purpose: To determine if all available existing data needed has been addressed in the Draft Document;

To determine if the available data is adequate for measuring environmental impacts;

To recommend what is needed to fill gaps in baseline data.

Groups: Geophysical

Water

Air and Noise

Biota

Socioeconomics

$3: 30 \quad$ BREAK

$3: 45$ GENERAL SESSION

Group reports and general discussion of baseline data

Geophysical

Water

Air and Noise

Biota

Socioeconomics 
Saturday, September 8, 1979

$7: 45 \quad$ REGISTRATION

8:15 GENERAL SESSION -- PANEL PRESENTATIONS

State and federal regulations affecting geothermal development and environmental quality

Leasing and drilling permits

Water quality

Air Quality

Noise Quality

Antiquities

Threatened and Endangered Species

NEPA Requirements

State and federal environmental study requirements

State

Federal

Environmental Assessment

Environmental Impact Statement

CASE STUDY: Environmental impact statement for a geothermal demonstration program, 50 $\mathrm{MW}_{\mathrm{e}}$ Power plant, Baca Ranch

QUESTIONS AND ANSWERS ON REGULATIONS

10:00 BREAK

10:15 SMALL GROUP DISCUSSIONS (On Section 5 of Draft Document)

Purpose: To identify the problems associated with potential environmental impacts

Groups: Geophysical

Water

Air and Noise

Biota

Socioeconomics

12:00 LUNCH (at Convention Center)

1:30 SMALL GROUP DISCUSSIONS (On Section 6 of the Draft Document)

Purpose: To make recommendations on the priority of impacts and on future environmental data collection activites within the state.

Groups: Same as in morning session 
3:00 BREAK

3:15 GENERAL SESSION

Group reports on conclusions from morning and afternoon sessions Geophysica1

Water

Air and Noise

Biota

Socioeconomics

General Summary of Workshop Results 
AAR

ÄES

alluvium

andesite

anticline

aquifer

artesian

artesian water

basalt

base temperature

bed rock
Association of American Railroads

Agricultural Experiment Station located at New Mexico State University, Las Cruces, New Mexico

a general term for all detrital deposits resulting from the operations of modern rivers and stream, usually sand and grave1

a volcanic rock of intermediate composition, commonly a deep reddish purple color

an upwarped fold of rock layers

a water-bearing statum of permeable rock, sand or gravel

groundwater that has sufficient hydrostatic head to rise above its aquifer

groundwater that is under sufficient pressure to rise above the level at which it is encountered (by a well), but does not necessarily rise to or above the surface of the ground

a dark, fine-grained volcanic :rock, composed of calcium plagioclase and pyroxene

the maximum temperature attained by geothermal water during convective circulation

a general term for rock, usually solid, that underlies soil or other unconsolidated, superficial material

Bureau of Indian Affairs

Bureau of Land Mangement 
boiling point

brine

British thermal unit

caldera

calorie

carbon monoxide (CO)

chemical geothermometer

CID

condensate

critical point

crust the temperature at which the vapor pressure of a liquid is equal to the pressure of the atmosphere of the liquid

a highly saline solution. A solution containing appreciable amounts of $\mathrm{NaCl}$ and other salts

the quantity of heat required to raise the temperature of 1 pound of water $1^{\circ} \mathrm{F}$ at or near its point of maximum density (equivalent to 252 calories)

a large basin-shaped volcanic depression, circular in form, with a diameter many times greater than the included volcanic vent. The steepness of the walls or form of the floor does not matter

the quantity of heat needed to raise one gram of water $1^{\circ} \mathrm{C}$ at or close to $16^{\circ} \mathrm{C}$

a colorless, odorless and tasteless gas which has a deleterious effect in relatively small concentrations. It is produced primarily from incomplete combustion in fuels used in vehicles, industries and space heating

the technique of pre-drilling assessment of temperature characteristics of the geothermal reservoir. Most widely used geothermometers are the $\mathrm{SiO}_{2}$ content, and $\mathrm{Na}, \mathrm{Ca}$, and $\mathrm{K}$ ratios measured in water samples

Commerce and Industry Department

the liquid recovered from the condensation of gasses or steam produced from a geothermal reservoir

the temperature and pressure at which the properties of a liquid and its vapor become indistinguishable

the lithosphere, or solid exterior portion of the earth 
cubic foot per second (cfs)

$d B$

discharge

DOE

drainage area

drainage basin

drilling mud

drilling operations

dry rock

effluent the rate of discharge representing a volume of one cubic foot passing a given point during one second, and equivalent to 7.48 gallons per second or 448.8 gallons per minute

decibel

the volume of water (or more broadly, total fluids) that passes a given point within a given period of time

Department of Energy

a stream at a specific location is that area, measured in a horizontal plane, enclosed by a topographic divide from which direct surface runoff from precipitation normally drains by gravity into the stream above the specified point

part of the surface of the earth that is occupied by a drainage system, which consists of a surface stream of body of impounded surface water together will tributary surface stream bodies of impounded surface water

a suspension, generally aqueous, used in rotary drilling. It is pumped downward through drill pipe to seal off porous zones and to counter-balance the pressure of oil, gas, and water

the actual drilling, redrilling, completion, recompletion of a well for geothermal production or injection, including the running and cementing of casing, the performance of such operations as logging and perforating, and the installation of wellhead equipment

rocks beneath the earth's surface that do not have meteoric or juvenile water supplied to them by an aquifer to any other source

1) something that flows out, as an outflowing branch of a main stream or lake; 2) waste material (as smoke, liquid industrial refuse, or sewage) discharged into the environment, especially when serving as a pollutant 213 
EIB

EID

EMD

endothermic

EPA

ep ithermal

exothermic

exploratory well

fault

fault blocks

fissure

flash steam

fumarole

$\mathrm{g} / \mathrm{m}^{3}$
Environmental Improvement Board

Environmental Improvement Division

Energy and Minerals Department

characterized by or formed with adsorption of heat

Environmental Protection Agency

a deposit formed from low-temperature hydrothermal solutions in rocks at shallow depths

designating, or pertaining to a reaction that occurs with a liberation of heat

a well drilled for the discovery or evaluation of geothermal resources one mile or more beyond the established limits of a designated geothermal field

a fracture or fracture zone along which there has been displacement of the sides relative to one another parallel to the fracture.

a mass bounded on at least two opposite sides by faults. It may be elevated or depressed relative to the adjoining regions, or it may be elevated relative to the region on one side and depressed relative to that on the other

an extensive crack, break or fracture in rock; a mere joint or crack persisting only for a few inches or even a few feet is not usually termed fissure by geologists or miners, although in a strict physical sense it is

the steam generated when the pressure on hot water (usually above $100^{\circ} \mathrm{C}$ ) is reduced

a hole or vent from which fumes or vapors issue; a spring or geyser that emits steam or gaseous vapor; usually found in volcanic areas

grams per cubic meter 
geochemical anomaly

geopressurized

geotherm (geoisotherm)

geothermal energy

geothermal field

geothermal flux

geothermal observation well

geothermal reservoir

geotherma1 resource base

geothermal resources a cencentration of one or more elements in rock, soil, sediment, vegetation, or water markedly different from the normal concentration in the surroundings

zones below depths of 6,000 to 10,000 feet in which sediments in basins are commonly characterized by abnormally high pressure, high temperature, and low salinity

a curving surface within the earth along which the temperature is constant

the internal energy of the earth, available to man as heat from heated rocks or water

an area defined by the 0il Conservation Division of New Mexico which contains a well or wells, capable of commerical geothermal production

a vector quantity that measures the heat flow from the interior of the earth toward the surface

a well drilled solely for temperature observation purposes, and which shall not be completed as a geothermal producing well or as an injection well

any common source of geothermal resources, whether the fluids produced from the reservoir are native to the reservoir, or flow into or are injected into said reservoir

al1 of the stored heat above $30^{\circ} \mathrm{C}$ to a depth of $10 \mathrm{~km}$ (NM definition)

the natural heat of the earth, or the energy, in whatever form, below the surface of the earth present in, resulting from, created by, or which may be extracted from, this natural heat, and a11 minerals in solution or other products obtained from naturally heated fluids, brines, associated gases, and steam, in whatever form, found below the surface of the earth, but excluding oil, hydrocarbon gas and other hydrocarbon substances 
geothermal resource area

geothermal waters

geothermic; geothermal

geyser

hardness

HED

heat flow

heat pipe

heat pump

$\mathrm{Hz}$ the same general surface area which is underlain, or appears to be underlain by one or more formations containing geothermal resources

the water or brine produced from a geothermal reservoir

the heat of the earth's interior

a spring that throws forth intermittent jets of heated water or steam; the heat is thought to result from the contact of groundwater with hot rock

of water is a physical-chemical characteristic attributable to the presence of alkaline earths (principally calcium and magnesium) and is expressed as equivalent calcium carbonate

Health and Environment Division

dissipation of heat coming from within the earth by conduction (e.g., heat flow from a magma into its surroundings) or radiation (radiation from breakdown of radioactive elements) measured at the earth's surface

a closed system (usually in the form of a closed pipe) in which heat is transferred from one end to the other by a transfer of working medium within the pipe accompanied by a change of phase at each end; because of the large amounts of heat involved in the phase changes, large amounts of heat can be transferred, relative to metallic conduction, provided the circulation of the working medium can be effected

a device which, by the consumption of work or heat, effects the transport of heat between a lower temperature and a high temperature; in conventional usage, the term is usually limited to a device whose useful output is heat; a device whose useful output is the removal of heat is called a refrigerator

hertz or cycles per second of sound 
high-temperature reservoirs

hot igneous system

hot rock

hot spring

hot-water system

HUD

hyd rology

hydrostatic head

hydrothermal

hydrothermal alteration reservoirs with base temperatures greater than $150^{\circ} \mathrm{C}$ as defined by the U.S. Geological Survey Circular 726

a system in which the thermal anomaly is derived from igneous formations in the upper $10 \mathrm{~km}$ of the crust

pertains to any rock that is volcanically or radiogenically heated

a thermal spring whose water has a higher temperature than that of the human body $\left(98.6^{\circ} \mathrm{F}\right)$

a system that is dominated by a circulating liquid that transfers most of the heat and largely controls subsurface pressures. Characterized by hot springs that discharge at the surface

Housing and Urban Development.

the science that deals with the properties, distribution, and circulation of water on the surface of the land, in the soil and underlying rocks, and in the atmosphere

the height to which water will rise in an open column by virtue of the pressure upon it

an adjective applied to heated or hot aqueous-rich solutions, to the processes in which they are concerned, and to the rocks, ore deposits, and alterations products produced by them; hydrothermal solutions are of diverse sources, including magmatic, meteoric, and connate waters

the phase changes resulting from the interaction of hydrothermal fluids with pre-existing solid phases. Included are the chenical and mineralogical changes in rocks brought about by the addition or removal of materials through the medium of hydrothermal fluids 
hydrothermal convective systems

hydrostatic head

hydrothermal

hydrothermal alteration

hydrothermal convective sys tems

hypothermal

igneous

impermeable

injection

injection we11 in such a system most of the heat is transferred by the convective circulation of water or steam rather than by thermal conduction through solid rock

the height to which water will rise in an open column by virtue of the pressure upon it

an adjective applied to heated or hot aqueous-rich solutions, to the processes in which they are concerned, and to the rocks, ore deposits, and alterations products produced by them. Hydrotherma1 solutions are of diverse sources, including magmatic, meteoric, and connate waters

the phase changes resulting from the interaction of hydrothermal fluids with pre-existing solid phases; included are the chemical and mineralogical changes in rocks brought about by the addition or removal of materials through the medium of hydrothermal fluids

in such a system most of the heat is transferred by the convective circulation of water or steam rather than by thermal conduction through solid rock

pertaining to hydrothermal ore veins deposited at relative high temperatures $\left(300^{\circ}\right.$ to $\left.500^{\circ} \mathrm{C}\right)$

rocks formed by solidification from a molten state (magma)

not allowing passage of water

the placing of fluids in an underground stratum through a wellbore, whether by pressure at the surface or by gravity flow, and whether for disposal or other purpose

a well drilled or converted for the purpose of injecting fluids into a geothermal reservoir 
instantaneous discharge

isothermal process

juvenile water

KGRA

KGRF

latent heat

lava

leaching

LASL

LLL

log, we11 $\log$

low-temperature reservoir the discharge at a particular instant of time; if this discharge is reported instead of the daily mean, the heading of the discharge column in the tables is "Discharge (cfs)"

a process that takes place at a constant temperature. Isothermal relationships between pressure and volume of a gas or other fluid result when the temperature is constant and when heat is added or substracted by an outside substance or body

water that is derived from the interior of the earth and has not previously existed as atmospheric or surface water

Known Geothermal Resource Area; a federa1 designation of land area in which geothermal leases have been or may be competitively sought.

Known Geothermal Resource Field; a state designation similar to a KGRA.

the quantity of heat absorbed or released in an isothermal transformation of phase

fluid rock that issues from a volcano or a fissure in the earth's surface; also the same material solidifed by cooling

washing or draining by percolation; to dissolve minerals or metals from ore by using acid or water

Los Alamos Scientific Laboratories located at Los Alamos, New Mexico

Lawrence Livermore Laboratory located at Livermore, California

a systematic detailed and correct recorded description of the lithologic sequence encountered while drilling a geothermal well

geothermal reservoirs with base temperatures less than $90^{\circ} \mathrm{C}$ 
low-temperature thermal field

low-temperature thermal water

low-temperature thermal well

magma

magmatic water

mean concentration

mean discharge

meteoric water

micrograms per liter

microseismics an area defined by the $0 i 1$ Conservation Division which contains a we11, or wells, capable of production of low-temperature thermal waters

naturally heated water the temperature of which is less than boiling at the altitude of occurrence, which has value by virtue of the heat contained therein, and is found below the surface of the earth, or in warm springs on the surface

a well drilled to produce
low-temperature thermal water for the
purpose of extracting heat for
agricultural, commercial, industrial,
municipal, or domestic uses

molten rock material within the earth from which an igneous rock results by cooling

water that exists in or is derived from molten igneous rock or magma

the time-weighted concentration of suspended sediment passing a stream section during a 24-hour day

the arithmetic average of individual discharges during a specific period

what that occurs in or is derived from the atmosphere

a unit for expressing the concentration of chemical constituents in solution as weight (micrograms) of solute per unit volume (liter) of water. One thousand micrograms per liter is quivalent to one milligram per liter

more-or-less persistent feeble earth tremors due to natural causes such as winds or strong ocean wave motion or hot brines 
milliequivalents per liter

milligrams per liter

mud pot

mud volcano

multiple completion

MWE (MW $\left.{ }_{\mathrm{e}}\right)$

NCSL

neck

NEPA

nitrogen dioxide $\left(\mathrm{NO}_{2}\right)$ is a unit for expressing chemical equivalent concentrations of ions or constitutents in solution; concentrations in milligrams per liter are converted to milliequivalents per liter by multiplying by the appropriate factors. The factors are reciprocals of equivalent weights and are calculated by dividing the valences by the atomic or formula weights. The term "milliequivalents" is a contraction of the more precise term "milligram equivalents"

a unit for expressing the concentration of chemical constituents in solution; milligrams per liter represents the weight of solute per unit volume of water. Milligrams per liter may be converted to parts per million (ppm) by dividing the density in grams per milliliter. Concentration of suspended sediment also is expressed in.mg/1, and is based on the weight of sediment per liter of water-sediment mixture

a type of hot spring consisting of a shallow pit or cavity filled with hot, boiling mud which carries very little water and a large amount of fine-grained mineral matter

a cone-shaped mound with a maximum height of 250 feet built around a spring by mud brought to the surface by slowly escaping natural gas

the completion of a well in such a manner as to produce from more than one geothermal reservoir

megawatt electric

National Council of State Legislatures

a lava-filled conduit of an extinct volcano that is exposed by erosion

National Environmental Protection Act

a reddish-orange-brown gas with a characteristics pungent odor. It is corrosive, highly oxidizing and may be physiologically irritating and toxic 
NME I /NMSU

norma1 fault

NPS

NRD

OCD

OSHA

overdraft

ozone $\left(\mathrm{O}_{3}\right)$

paramarginal geothermal resources

partial record station

particle size

particle-size classification
New Mexico Energy Institute, located at New Mexico State University, in Las Cruces, New Mexico

a fault where the hanging wall has been depressed relative to the foot wall

Nationa1 Park Service

Natural Resources Department

Oil Conservation Division

Occupation Safety and Health Act

for a geothermal source, when the ratio of heat removed by a fluid (water or steam) to the normal heat flow into the volume of the fluid exceeds unity, the ratio is called the overdraft

a colorless gas produced when reactive organic substances and nitrogen oxides accumulated in the atmosphere react with the ultraviolet light in sunlight

the resources that are recoverable at a cost of between one and two times the current price of competitive energy

a particular site where limited streamflow data are collected systematically over a period of years for use in hydrologic analyses

the diameter, in millimeters, of suspended sediment or bed material determined either by sieve or sedimentation methods

used in this report agrees with recommendations made by the American Geophysical Union Subcommittee on Sediment Terminology:

$\begin{array}{lll}\text { Classification } & \text { Size }(\mathrm{mm}) & \text { Method of analysis } \\ \text { C1ay } & 0.0024-0.004 & \text { Sedimentation } \\ \text { Silt } & 0.004-0.062 & \text { Sedimentation } \\ \text { Sand } & 0.062-2.0 & \text { Sedimentation or sieve } \\ \text { Gravel } & 2.0-64.0 & \text { Sieve }\end{array}$


permeability

permeable rock

phreatic water

picocurie per liter

PNM

porosity

potentia1

$\mathrm{ppb}$

$\mathrm{ppm}$

regressive boiling the permeability of a rock is its capacity for transmitting a fluid. Degree of permeability depends upon the size and shape of the pores, the size and shape of their interconnections, and the extent of the latter. It is measured by the rate at which a fluid of standard viscosity can move a given distance through a given interval of time. The unit of permeability is the "darcy"

having a texture that permits water to move through it perceptibly under the head differences ordinarily found in subsurface water. A permeable rock has communicating interstices of capillary or supercapillary size

a term originally applied only to water that occurs in the upper part of the zone of saturation under water-table conditions. Now it is applied to all water in the zone of saturation; thus making it an exact" synonym of groundwater

one trillionth $\left(1 \times 10^{12}\right)$ of the amount of radioactivity represented by a curie (C or $\mathrm{Ci}$ ). A curie is the amount of radioactivity that yields $3.7 \times 10$ radioactive disintegrations per second. A picocurie yields 2.22 disintegrations per minute

Public Service Company of New Mexico, located in Albuquerque, New Mexico

the ratio of the aggregate volume of interstices in a rock or soil to its total volume; usually stated as a percent

the properly determined ability of a well to produce geothermal resources under conditions prescribed by the oil Conservation Division

parts per billion

parts per million

boiling that occurs in a liquid during a decrease in temperature 
reinjection

rhyolite

salinity

SCS

sediment

seismic

seismic attenuation

seismic discontinuity

sinter

sodium adsorption ratio the process of pumping waste water back into a well or aquifer

a light colored, fine-grained volcanic rock; compositional equivalent of granite

1) a measure of the quantity of total dissolved salts in water; 2) a measure of the total concentration of dissolved salts in saline water

Soil Conservation Service

solid material that originates mostly from disintegrated rocks and is transformed by, suspended in, or deposited from water; it includes chemical and biochemical precipitates and decomposed organic material such as humus; the quantity, characteristics, and cause of the occurrence of sediment in streams are influenced by environmental factors; some major factors are degree of siope, length of slope, soil characteristics, land usage, and quantity and intensity of precipitation

pertaining to an earthquake or earth vibration, including those that are artifically induced

that portion of the decrease in seismic signal strength with distance not dependent on geometrical spreading; the decrease depends on the physical characteristics of the transmitting media, involving reflection, scattering, and absorption

physical discontinuity within the earth separating materials in which seismic waves travel at significantly different velocities

a chemical sediment deposited by mineral springs, mostly silica $\left(\mathrm{SiO}_{2}\right)$

the expression of relative activity of sodium ions in exchange reactions with soil and is an index of sodium or alkali hazard to the soil. This ratio should be known especially water used for irrigated farmland 
solute

solution

space heating

specific conductance

specific heat

stage discharge relation

steam

streamflow an substance derived from the atmosphere, vegetation, soil or rocks that is dissolved in water

the homogeneous mixture of solutes and water. The solutes usually comprise a very small Eraction of the total weight of the mixture. For this reason, the terms "solution" and "water" are used interchangeab1y

the process of supplying the required heat for the physical comfort of human beings in houses, offices, or enclosed industrial plants; the heat required for a typical domestic dwelling on an average winter day in the U.S. is about $27,000 \mathrm{Btu} / \mathrm{h}$ or $7.8 \mathrm{~kW}$

a measure of the ability of water to conduct an electrical current and is expressed in microohms per centimeter at $25^{\circ} \mathrm{C}$; because the specific conductance is related to the number and specific chemical types of ions in solution, it can be used for approximating the dissolved-solids content in the water

the quantity of heat necessary to raise the temperature of $1 \mathrm{~g}$ of a given substance $1^{\circ} \mathrm{C}$

the relation between gage height and amount of water flowing in a channel, expressed as volume per unit of time

the invisible vapor into which water is converted when heated to the boiling point; a vapor arising from a heated substance

the discharge that occurs in a natural channel; although the term "discharge" can be applied to the flow of a canal, the world "streamflow" uniquely describes the discharge in a surface stream course; streamflow may be applied to discharge whether or not it is affected by diversion or regulation 
subsidence

sulfur dioxide $\left(\mathrm{SO}_{2}\right)$

suspended sediment

syncline

teleseism

temperature

temporary abandonment

thermal waters

thermal spring

thermograph

total dissolved solids
1) a sinking of a large part of the earth's crust; 2) movement in which there is not free side and surface material is displaced vertically downward with 1ittle or no horizontal component

colorless, nonflammable, odiferous gas with corrosive qualities; high concentrations can be found near copper smelters. and industries burning fossil fuels containing sulfur

the sediment that at any given time is maintained in suspension by the upward components of turbulent currents or that exists in suspension as a colloid

a downwarped fold of rock layers

an earthquake whose epicenter is over $1000 \mathrm{~km}$ away

a manifestation of " the average translational kinetic energy of the molecules of a substance caused by heat agitation

a state or period of suspended operations during which essentially containuous drilling, production, injection, storage, or work-over procedures have not taken place. Such period shall be 60 days for drilling wells and six months for all other classes or wells.

pertains to water heated by a natural or artifical agency

a natural spring flowing at least $15^{\circ} \mathrm{F}$ above mean annual surface temperature

a temperature sensing device that continuously or automatically records, on a chart, the water temperature of a stream

TDS are chemical constituents determined by addition of component parts or by direct measurement 
total sediment load

total suspended particulates

travertine

Union $\mathrm{Oil}$

USFS

USGS

vapor dominated

vaporization

vapor pressure

volcanic

waste the sum of the suspended-sediment discharge and the bedload discharge. It is the total quantity of sediment, assured by dry weight or volume, that is discharged during a given time

TSP are matter, either solid or liquid, dispersed in the atmosphere. Particles are of varying size and may remain suspended in the air for periods ranging from seconds to several months

a chemical sediment deposited by mineral springs, commonly calcium carbonate $\left(\mathrm{CaCO}_{3}\right)$

Union Oil of New Mexico, located at Rio Rancho, New Mexico

United States Forest Service

United States Geological Survey

a geothermal system in. which pressures are controlled by vapor rather than by liquid

the process by which a liquid is converted into a vapor

the pressure at which a liquid and its vapor are in equilibrium at a, given temperature

of, pertaining to, like or characteristic of a volcano; characterized by or composed of volcanoes; produced, influenced, or changed by a volcano or by volcanic agenices; made of materials derived from volcanoes especially rocks erupted and solidified at the surface

any physical waste including, but not limited to, underground waste resulting from the inefficient, excessive or improper use of dissipation of reservoir heat or energy or resulting from the location, spacing, drilling, equipping, operation or production of a geothermal resources well in such a manner as to reduce or tend to reduce the ultimate economic recovery of the geothermal 
water table

we 11

WRD

WRRI

WSP resources within a reservoir, and surface waste resulting from the inefficient production, gathering, transportation, storage, or utilization of geothermal resources, and the handling of geothermal resources in such a manner that causes ore tends to cause the unnecessary or excessive loss or destruction of geothermal resources obtained or released from a geothermal reservoir.

the surface between the "zone of saturation" and the "zone of aeration"; that surface of a body of unconfined groundwater at which the pressure is equal to that of the atmosphere

any exploratory we11, development well, injection we11, disposal well, geothermal observation we11, or low-temperature thermal wel1 as defined by the $0 i 1$ conservation Division

used as an abbreviation for "water-resources data"

Water Resources Research Institute

used as an abbreviation for "water-supply paper" 
APPENDIX E

GENERAL SOCIOECONOMIC INFORMATION BY NEW MEXICO COUNTY

(Bureau of Business and Economic Research, 1977) 
Bernalillo County, general socioeconomic information:

County Area (in acres):

748,160

County Seat:

Al buquerque

Population:

653,450

Population Components:

$\%$ Rural

5.8

$\%$ Nonwhite

4.7

\% Spanish-heritage

39.2

$\%$ Over 64

6.7

Vital Statistics:

Births

Deaths

Natural increase

Inferred net migration

30,113

10,949

19,164

29,240

Taxes and Revenues (1975): $\quad \$ 1,589,450$

Trade and Services (1972):

Total retail sales

Total wholesale receipts

$\$ 1,719,718$

Total receipts of services

Catron County, general socioeconomic information.

County Area (in acres):

$4,414,720$

County Seat:

Reserve

Population:

2,300

Population Components:

\% Rural

$\%$ Nonwhite

$\%$ Spanish-heritage

$\%$ Over 54

100.0

1.8

42.2

12.3

Vital Statistics:

Births

Deaths

Natural increase

67

Inferred net migration

30

Taxes and Revenues (1975):

$\$ 14,983$

Trade and Services (1972):

Total retail sales

Total wholesale receipts

Total receipts of services

$\$ \quad 1,945$

W 
"Chaves County" general sociaeconomic information.

County Area (in acres):

$3,900,300$

County Seat:

Roswell

Population:

89,300

Population Components:

$\%$ Rural

27.8

$\%$ Nonwhite

5.5

$\%$ Spanish-heritage

\% Over 64

27.9

9.0

Vital Statistics:

Births

3,876

Deaths

2,748

Natural increase

1,728

Inferred net migration

3,070

Taxes and Revenues (1975):

$\$ 168,567$

Trade and Services (1972):

Total retail sales

Total wholesale receipts

Total receipts of services

Colfax County, general socioeconomic information.

County Area (in acres):

County Seat:

Population:

Population Components:

$\%$ Rural

$\%$ Nonwhite

$\%$ Spanish-heritage

$\%$ Over 64
$2,413,440$

Raton

12,900

42.8

1.3

53.1

12.3

1,109

636

473

230

Inferred net migration

Taxes and Revenues (1975):

$\$ \quad 49,571$

Trade and Services (1972):

Total retail sales

Total wholesale receipts

Total receipts of services
$\$ 44,364$

$\$ 10,908$

$\$ 6,986$ 
Curry County, deneral socioeconomic information.

County Area (in acres'):

County Seat:

Population:

Population Components:

$\%$ Rural

$\%$ Nonwhite

$\%$ Spanish-heritage

$\%$ Over 64

Vital Statistics:

Births

Deaths

Natural increase

Inferred net migration

Taxes and Revenues (1975):

Trade and Services (1972):

Total retail sales

Total wholesale receipts

Total receipts of services
898,560

Clovis

76,300

14.1

8.1

17.4

7.4

4,959

1,394

3,565

40

143,042

177,403

203,549

22,329

De Baca County, general socineconomic information.

County Area (in acres):

County Seat:

Population:

Poputation Components:

$\%$ Rural

$\%$ Nonwhite

\% Spanish-heritage

$\%$ Over 64

Vital Statistics:

Births

Deaths

Natural increase

Inferred net migration

Taxes and Revenues (1975):

Trade and Services (1972):

Total retail sales

Total wholesale receipts

Total receipts of services
$1,574,240$

Ft. Sumner

4,275

100.0

0.4

40.8

18.1

167

167

$-6$

110

$\$ \quad 10,711$

$\$ 4,166$

$\$ 2,969$

$\$ 616$ 
Dona Ana County, general socioeconomic information.

County Area (in acres):

County Seat:

Population:

Population Components:

$\%$ Rural

$\%$ Nonwhite

\% Spanish-heritage

$\%$ Over 64

Vital Statistics:

Births

Deaths

Natural increase

Inferred net migration

Taxes and Revenues (1975):

Trade and Services (1972):

Total retail sales

Total wholesale receipts

Total receipts of services

$$
2,434,560
$$

Las Cruces

123,450

33.8

3.3

50.8

5.3

7,851

2,104

5,747

4,350

$\$ 245,668$

$\$ 253,934$

$\$ 110,627$

$\$ 38,394$

Eddy County, general socioeconomic information.

County Area (in acres):

County Seat:

Population:

Population Components:

$\%$ Rural

$\%$ Nonwhite

$\%$ Spanish-heritage

$\%$ Over 64

Vital Statistics:

Births

Deaths

Natural increase

Inferred net migration

Taxes and Revenues (1975):

Trade and Services (1972):

Total retail sales

Total wholesale receipts

Total receipts of services

$$
2,675,200
$$

Carlsbad

78,675

23.1

2.9

30.5

8.9

3,466

1,844

1,622

- 320

$\$ 346,020$

$\$ 156,924$

$\$ 65,162$

$\$ 23,760$ 
Grant County, general socioeconomic information.

County Area (in acres):

County Seat:

Population:

Population Components:

$\%$ Rural

$\%$ Nonwhite

$\%$ Spanish-heritage

\% Over 64

Vital Statistics:

Births

Deaths

Natural increase

Inferred net migration

Taxes and Revenues (1975):

Trade and Services (1972):

Total retail sales

Total wholesale receipts

Total receipts of services

$$
2,540,800
$$

Silver City

40,550

51.6

1.7

56.7

7.9

2,463

920

1,543

960

$\$ 212,869$

$\$ 87,300$

$\$ 26,125$

$\$ 7,278$

Guadalupe County -- general socioeconomic information.

County Area (in acres):

$1,919,360$

County Seat:

Santa Rosa

Population:

7,425

Population Components:

$\%$ Rural

$\%$ Nonivhite

100.0

$\%$ Spanish-heritage

0.5

$\%$ Over 64

84.5

9.4

Vital Statistics:

Births

Deaths

Natural increase

Inferred net migration

$-230$

Taxes and Revenues (1975):

$\$ \quad 18,614$

Trade and Services (1972):

Total retail sales

Total wholesale receipts

Total receipts of services

$\begin{array}{lr}\$ & 15,109 \\ \$ & 1,713 \\ \$ & 1,566\end{array}$ 
Harding County -- general socioeconomic information.

\begin{tabular}{|c|c|}
\hline County Area (in acres): & $1,368,320$ \\
\hline County Seat: & Mosquero \\
\hline Population: & 1,200 \\
\hline $\begin{array}{l}\text { Population Components: } \\
\% \text { Rural } \\
\% \text { Nonwhite } \\
\% \text { Spanish-heritage } \\
\% \text { Over } 64\end{array}$ & $\begin{array}{r}100.0 \\
0.5 \\
49.3 \\
14.6\end{array}$ \\
\hline $\begin{array}{l}\text { Vital Statistics: } \\
\text { Births } \\
\text { Deaths } \\
\text { Natural increase } \\
\text { Inferred net migration }\end{array}$ & $\begin{array}{r}61 \\
61 \\
0 \\
-\quad 100\end{array}$ \\
\hline Taxes and Revenues (1975): & 5,118 \\
\hline $\begin{array}{l}\text { Trade and Services (1972): } \\
\text { Total retail sales } \\
\text { Total wholesale receipts } \\
\text { Total receipts of services }\end{array}$ & $\begin{array}{r}1,344 \\
1,696 \\
31\end{array}$ \\
\hline
\end{tabular}

Hidalgo County -- general socioeconomic information.

County Area (in acres):

County Seat:

Population:

Population Components:

$\%$ Rural

$\%$ Nonwhite

$\%$ Spanish-heritage

$\%$ Over 64

Vital Statistics:

Births

Deaths

Natural increase

Inferred net migration

Taxes and Revenues (1975):

Trade and Services (1972):

Total retail sales

Total wholesale receipts

Total receipts of services
$2,206,080$

Lordsburg

9,600

27.6

1.4

58.3

8.8

588

228

360

640

$\$ 43,469$

$\$ 26,995$

3,682

5,426 


$$
\text { Lea County -- general socioeconomic information. }
$$
County Area (in acres):
2,$812 ; 160$
County Seat:
Lovington
Population:
94,125
Population Components:
$\%$ Rural
$\%$ Nonwhite
$\%$ Spanish-heritage
\% Over 64
18.9
6.3
12.5
5.4
Vital Statistics:
Births
Deaths
5,004
Natural increase
1,665
Inferred net migration
3,339
$-\quad 1,740$
Taxes and Revenues (1975):
$\$ 546,148$
Trade and Services (1972):
Total retail sales
Total wholesale receipts
Total receipts of services
$\$ 201,019$
$\$ 151,754$
$\$ \quad 40,119$

Lincoln County -- general socioeconomic information.

County Area (in acres):

County Seat:

Population:

Population Components:

$\%$ Rural

$\%$ Nonwhite

$\%$ Spanish-heritage

$\%$ Over 64
$3,109,760$

Carrizozo

13,875

100.0

2.5

34.0

11.6

Vital Statistics:

Births

691

Deaths

362

Natural increase

Inferred net migration

329

1,570

Taxes and Revenues (1975):

$\$ 74,127$

Trade and Services (1972):

Total retail sales

Total wholesale receipts

Total receipts of services
$\$ 21,678$

$\$ 2,121$

$\$ \quad 6,568$ 
Los Alamos County -- general socioeconomic information.

County Area (in acres):

69,120

County. Seat:

Los Alamos

Population:

15,900

Population Components:

$\%$ Rural

$\%$ Nonwhite

1.3

$\%$ Spanish-heritage

$\%$ Over 64

17.8

2.1

Vital Statistics:

Births 898

Deaths 257

Natural increase $\quad 647$

Inferred net migration $\quad 50$

Taxes and Revenues (1975): $\quad \$ 48,834$

Trade and Services (1972):

Total retail sales

Total wholesale receipts

Total receipts of services

$\$ 26,655$

$\$ 396$

Luna County -- general socioeconomic information.

County Area (in acres):

$1,892,480$

County Seat:

Deming

Population:

23,900

Population Components:

$\%$ Rural

$\%$ Nonwhite

28.7

\% Spanish-heritage

$\%$ Over 64

2.6

46.5

10.2

Vital Statistics:

Births

Deaths

Natural increase

Inferred net migration

1,370

705

665

2,140

Taxes and Revenues (1975):

$\$ \quad 64,577$

Trade and Services (1972):

Total retail sales

Total wholesale receipts

Total receipts of services

$\begin{array}{rr}\$ & 60,459 \\ \$ & 18,700 \\ \$ & 3,678\end{array}$ 
Mckinley County -- general socioeconomic information.

County Area (in acres):

County Seat:

Population:

Population Components:

$\%$ Rural

\% Nonwhite

$\%$ Spanish-heritage

\% Over 64

Vital Statistics:

Births

Deaths

Natural increase

Inferred net migration

Taxes and Revenues (1975):

Trade and Services (1972):

Total retail sales

Total wholesale receipts

Total receipts of services
$3,495,050$

Gal Tup

66,500

57.1

63.0

20.0

4.4

7,008

1,922

5,086

2,710

$\$ \quad 118,928$

$\$ 207,060$

$\$ 71,456$

$\$ 22,605$

Mora County -- general socioeconomic information.

County Area (in acres):

County Seat:

Population:

Population Components:

$\%$ Rural

$\%$ Nonwhite

\% Spanish-heritage

\% Over 64

Vital Statistics:

Births

Deaths

Natural increase

Inferred net migration

Taxes and Revenues (1975):

Trade and Services (1972):

Total retail sales

Total wholesale receipts

Total receipts of services
$1,244,160$

Mora

4,900

100.0

0.3

94.6

11.9

406

216

190

10

$\$ \quad 7,572$

1,665

$\$ 575$

$\$ 98$ 
Otero County. -- general socioeconomic information.

County Area (in acres):

County Seat:

Population:

Population Components:

$\%$ Rural

$\%$ Nonwhite

$\%$ Spanish-heritage

$\%$ Over 64

Vital Statistics:

Births

Deaths

Natural increase

Inferred net migration

Taxes and Revenues (1975):

Trade and Services (1972):

Total retail sales

Total wholesale receipts

Total receipts of services
$4,248,320$

Al amogordo

71,275

17.5

9.3

23.7

4.1

4,898

1,155

3,743

- 2,340

$\$ 102,526$

$\begin{array}{lr}\$ & 125,071 \\ \$ & 15,186 \\ \$ & 6,977\end{array}$

Quay County -- general socioeconomic information.

County Area (in acres):

County Seat:

Population:

Population Components:

$\%$ Rural

$\%$ Nonwhite

\% Spanish-heritage

$\%$ Over 64

Vital Statistics:

Births

Deaths

Natural increase

Inferred net migration

Taxes and Revenues (1975):

Trade and Services (1972):

Total retail sales

Total wholesale receipts

Total receipts of services
$1,845,120$

Tucumcari

19,250

34.1

2.1

36.0

12.5

951

691

260

240

$\$ \quad 58,092$

$\$ \quad 55,884$

$\$ 18,086$

$\$ 7,912$ 
Rio Arriba County -- general socioeconomic information.

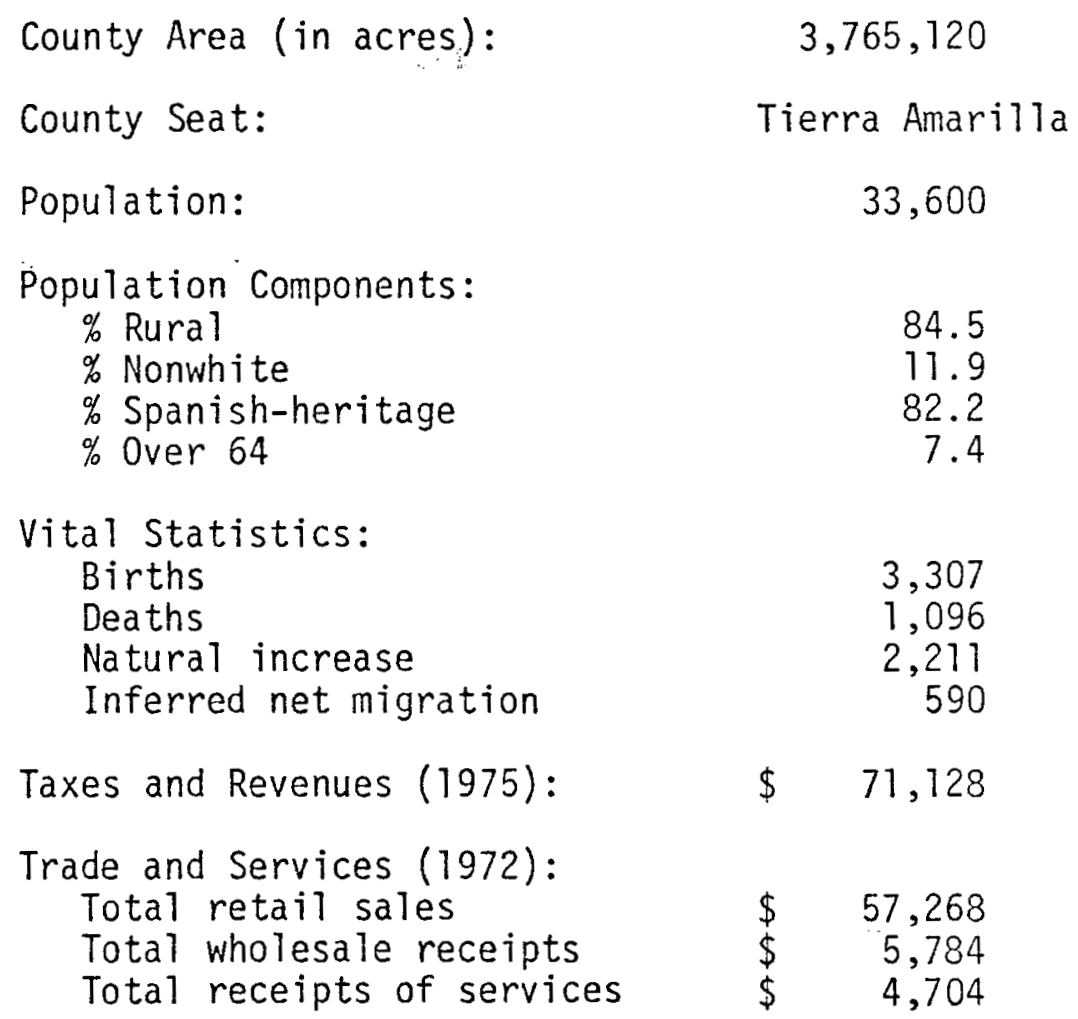

Roosevelt County -- general socioeconomic information.

County Area (in acres):

$1,572,480$

County Seat:

Portales

Population:

27,300

Population Components:
$\%$ Rural
36.0
$\%$ Nonwhite
2.3
\% Spanish-heritage
15.3
$\%$ Over 64
9.9

Vital Statistics:

$\begin{array}{lr}\text { Births } & 1,487 \\ \text { Deaths } & 712 \\ \text { Natural increase } & 775 \\ \text { Inferred net migration } & 980\end{array}$

Taxes and Revenues (1975): $\quad \$ \quad 51,307$

Trade and Services (1972):

Total retail sales

Total wholesale receipts

Total receipts of services 
Sandoval County -- general socioeconomic information.

County Area (in acres):

$2,378,880$

County Seat:

Bernalillo

Population:

25,375

Population Components :
$\%$ Rural
100.0
$\%$ Nonwhite
39.6
$\%$ Spanish-heritage
63.8
$\%$ Over 64
7.2

Vital Statistics:

Births

Deaths

Natural increase

2,497

912

1,585

Inferred net migration

3,520

Taxes and Revenues (1975):

$\$ 79,904$

Trade and Services (1972):

Total retail sales

Total wholesale receipts

Total receipts of services

$\begin{array}{ll}\$ & 13,078 \\ \$ & 1,194\end{array}$

San Juan County -- general socioeconomic information.

County Area (in acres):

$3,530,240$

County Seat:

Aztec

Population:

100,250

Population Components:

$\%$ Rural

51.8

$\%$ Nonwhite

36.1

\% Spanish-heritage

13.1

$\%$ Over 64

Vital Statistics:

Births

6,801

Deaths

1,879

Natural increase

4,922

Inferred net migration

7,680

Taxes and Revenues (1975):

$\$ 395,509$

Trade and Services (1972):

Total retail sales

Total wholesale receipts

Total receipts of services

$\$ 228,489$

$\$ \quad 110,682$

$\$ 68,368$ 
San Miguel County -- general socioeconomic information.
County Area (in acres):
$3,050,880$
County Seat:
Las Vegas
Population:
39,400
Population Components:
$\%$ Rural
37.0
$\%$ Nonwhite
$\%$ Spanish-heritage
1.7
\% Over 64
81.7
9.9
Vital Statistics:
Births
2,271
Deaths
996
Natural increase
1,275
Inferred net migration
230
Taxes and Revenues (1975): $\quad \$ \quad 58,126$
Trade and Services (1972):
Total retail sales
$\$ 67,546$
Total wholesale receipts
Total receipts of services
8,379
6,106

Santa Fe County -- general socioeconomic information.

County Area (in acres):

$1,221,760$

County Seat:

Santa $\mathrm{Fe}$

Population:

56,600

Population Components:

$\%$ Rural

$\%$ Nonwhite

3.0

\% Spanish-heritage

64.9

$\%$ Over 64

7.8

Vital Statistics:

Births

Deaths

5,382

Natural increase

Inferred net migration

2,170

3,212

3,890

Taxes and Revenues (1975):

$\$ 219,745$

Trade and Services (1972):

Total retail sales

Total wholesale receipts

Total receipts of services

$\$ 308,840$

$\$ 71,342$

$\$ 61,384$ 
Sierra County -- general socioeconomic information.

County Area (in acres):

County Seat:

Population:

Population Components:

$\%$ Rural

$\%$ Nonwhite

$\%$ Spanish-heritage

$\%$ Over 64

Vital Statistics:

Births

Deaths

Natural increase

Inferred net migration

Taxes and Revenues (1975):

Trade and Services (1972):

Total retail sales

Total wholesale receipts

Total receipts of services
$2,700,160$

Truth or Consequences

14,175

35.2

0.9

35.8

24.7

Socorro County -- general socioeconomic information.

County Area (in acres):

County Seat:

Population:

Population Components:

$\%$ Rural

$\%$ Nonwhite

$\%$ Spanish-heritage

\% Over 64

Vital Statistics:

Births

Deaths

Natural increase

Inferred net migration

Taxes and Revenues (1975):

Trade and Services (1972):

Total retail sales

Total wholesale receipts

Total receipts of services
$4,240,640$

Socorro

$$
15,675
$$

52.0

9.0

60.0

7.7

1,063

449

614

- 610

$\$ \quad 41,822$

$\$ 31,504$

$\$ 7,226$

$\$ 3,053$ 
Taos County -- general socioeconomic information.

County Area (in acres):

County Seat:

Population:

Population Components:

\% Rural

$\%$ Nonwhite

$\%$ Spanish-heritage

$\%$ Over 64

Vital Statistics:

Births

Deaths

Natural increase

Inferred net migration

Taxes and Revenues (1975):

Trade and Services (1972):

Total retail sales

Total wholesale receipts

Total receipts of services
$1,444,480$

Taos

$$
23,475
$$

100.0

8.6

86.3

9.3

1,897

752

1,145

660

$\$ 56,014$

\$2 28,695

\$ 4,673

$\$ \quad 6,601$

Torrance County -- general socioeconomic information.

County Area (in acres):

$2,147,200$

County Seat:

Estancia

Population:

7,400

Population Components:

$\%$ Rural

$\%$ Nonwhite

100.0

$\%$ Spanish-heritage

0.6

\% Over 64

52.6

11.9

Vital Statistics:

Births

Deaths

Natural increase

Inferred net migration

890

Taxes and Revenues (1975):

$\$ 25,037$

Trade and Services (1972):

Total retail sales

Total wholesale receipts

Total receipts of services

$\begin{array}{lr}\$ & 12,956 \\ \$ & 1,951 \\ \$ & 653\end{array}$ 
Union County -- general socioeconomic information.

\begin{tabular}{|c|c|c|}
\hline County Area (in acres): & & 2,880 \\
\hline County Seat: & & ton \\
\hline Population: & & 7,950 \\
\hline $\begin{array}{l}\text { Population Components: } \\
\% \text { Rural } \\
\% \text { Nonwhite } \\
\% \text { Spanish-heritage } \\
\% \text { Over } 64\end{array}$ & & $\begin{array}{r}40.5 \\
1.2 \\
28.3 \\
15.4\end{array}$ \\
\hline $\begin{array}{l}\text { Vital Statistics: } \\
\text { Births } \\
\text { Deaths } \\
\text { Natural increase } \\
\text { Inferred net migration }\end{array}$ & & $\begin{array}{r}386 \\
275 \\
111 \\
-110\end{array}$ \\
\hline Taxes and Revenues (1975): & $\$$ & 18,938 \\
\hline $\begin{array}{l}\text { Trade and Services (1972): } \\
\text { Total retail sales } \\
\text { Total wholesale receipts } \\
\text { Total receipts of services }\end{array}$ & $\begin{array}{l}\$ \\
\$ \\
\$\end{array}$ & $\begin{array}{r}18,536 \\
7,159 \\
2,347\end{array}$ \\
\hline
\end{tabular}

Valencia County -- general socioeconomic information.

County Area (in acres):

$3,621,120$

County Seat:

Los Lunas

Population:

62,700

Population Components:
$\%$ Rural
$\%$ Nonwhite
66.5
$\%$ Spanish-heritage
$\%$ Over 64
16.1
55.8
5.6

Vital Statistics:

Births

Deaths

4,273

1,454

Natural increase

2,819

Inferred net migration

2,680

Taxes and Revenues (1975):

$\$ 136,532$

Trade and Services (1972):

Total retail sales

Total wholesale receipts

Total receipts of services

$\$ \quad 111,021$

$\$ 19,344$

$\$ 9,837$ 


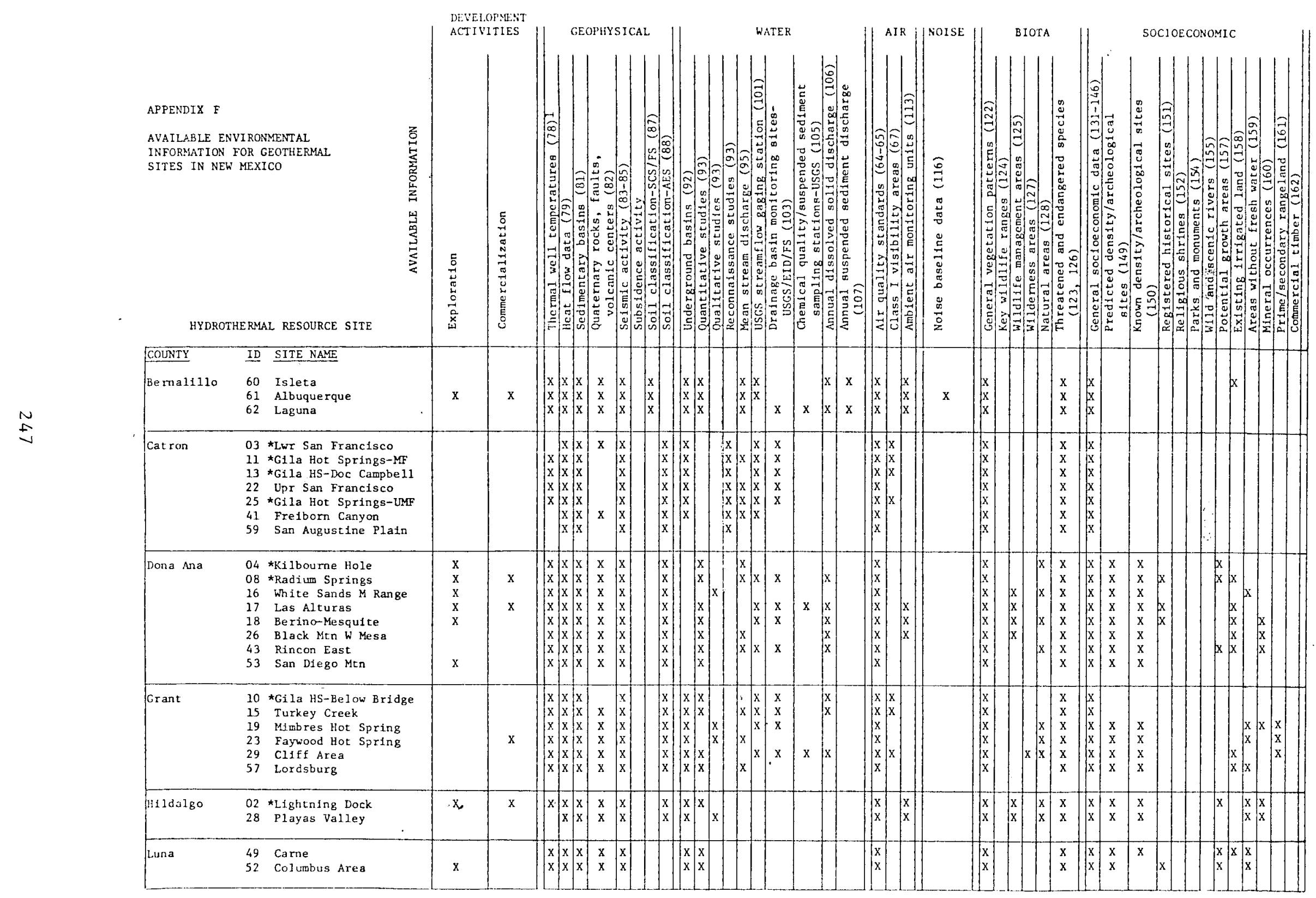




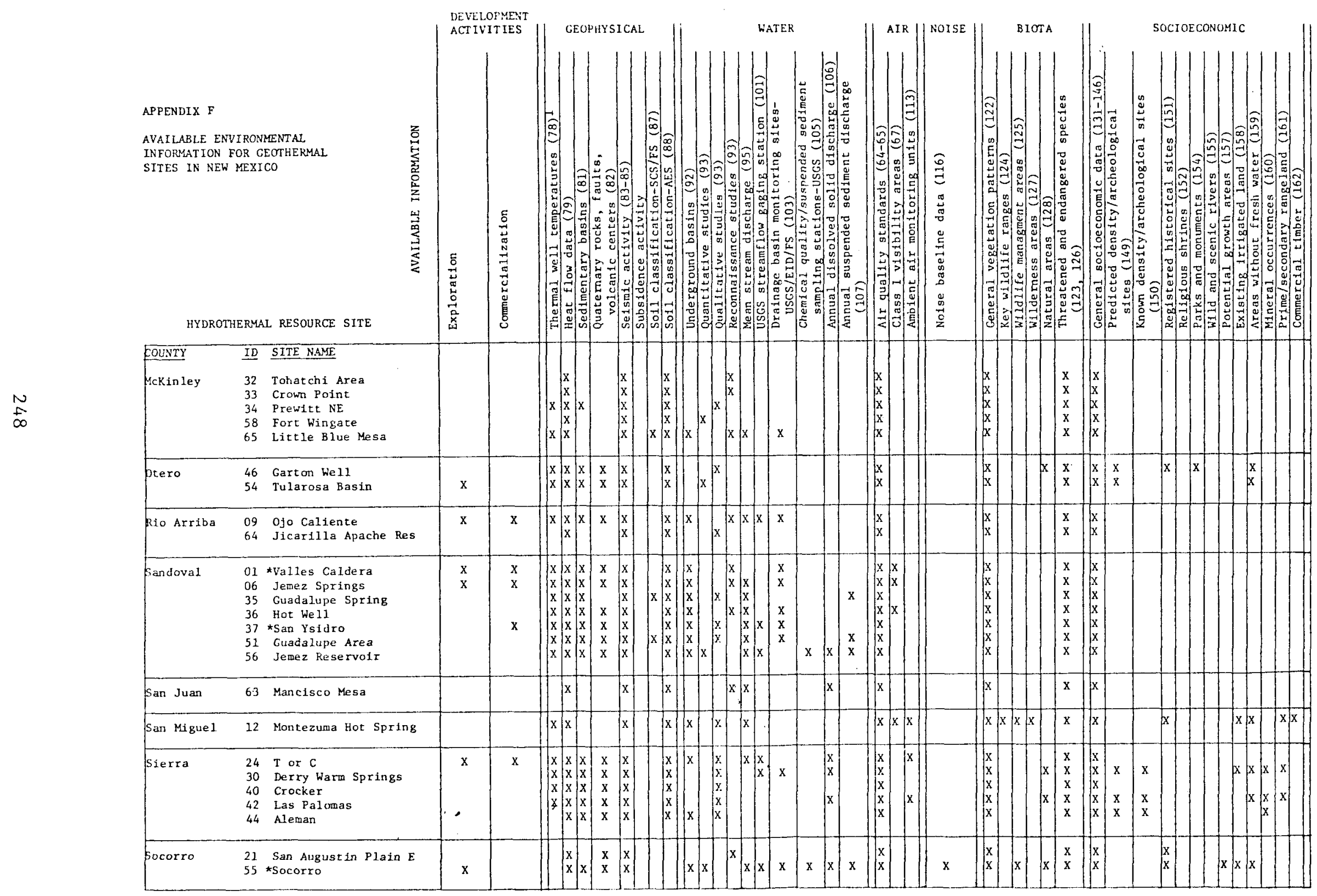




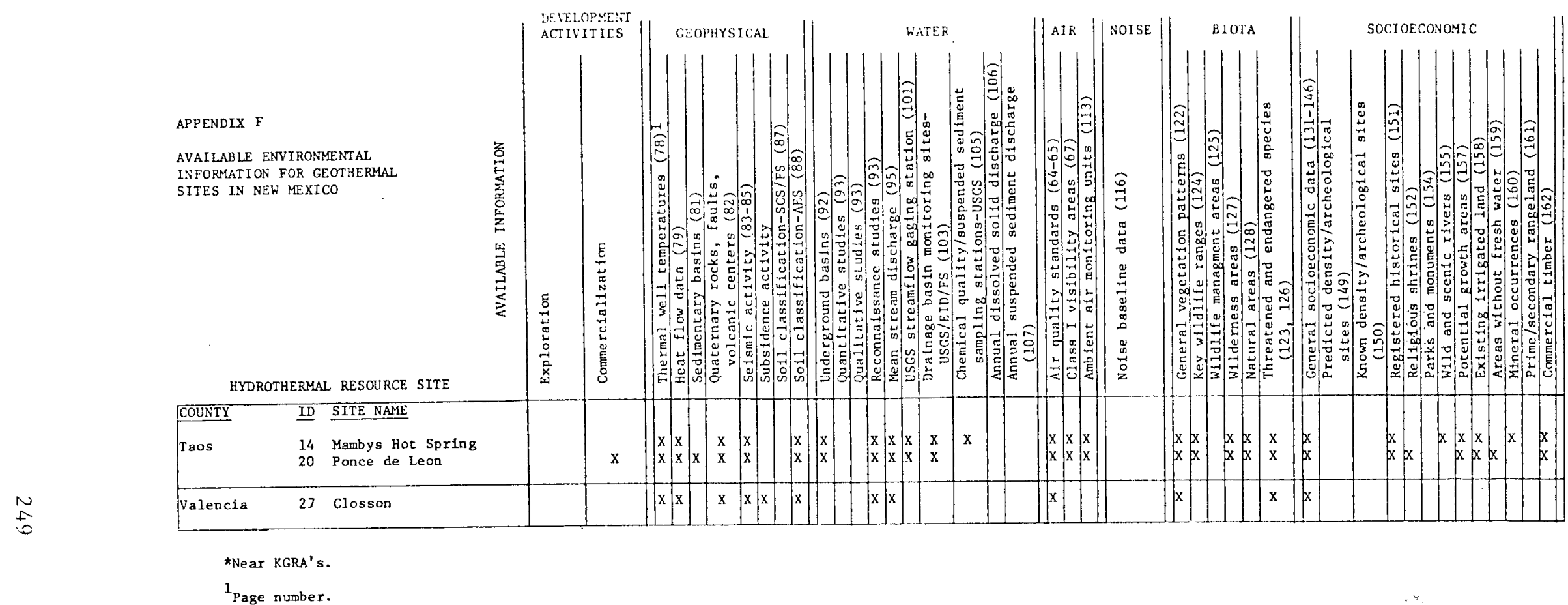

$1_{\text {Page number. }}$. 